Pre-Construction Biogeochemical Analysis of Mercury in Wetlands Bordering the Hamilton Army Airfield Wetlands Restoration Site

E. P. H. Best, H. L. Fredrickson, V. A. McFarland,

September 2005

H. Hintelmann, R. P. Jones, C. H. Lutz, G. A. Kiker,

A. J. Bednar, R. N. Millward, R. A. Price, G. R. Lotufo, and G. A. Ray 


\title{
Pre-Construction Biogeochemical Analysis of Mercury in Wetlands Bordering the Hamilton Army Airfield Wetlands Restoration Site
}

\author{
E. P. H. Best, H. L. Fredrickson, V. A. McFarland, R. P. Jones, C. H. Lutz, \\ G. A. Kiker, A. J. Bednar, R. A. Price, G. R. Lotufo, and G. A. Ray \\ Environmental Laboratory \\ U.S. Army Engineer Research and Development Center \\ 3909 Halls Ferry Road \\ Vicksburg, MS 39180-6199 \\ H. Hintelmann \\ Trent University \\ 1600 West Bank Drive \\ Peterborough, ON K9J 7B8, Canada \\ R. N. Millward \\ Analytical Services, Inc. \\ 3532 Manor Drive, Suite \#3 \\ Vicksburg, MS 39180
}

Interim report

Approved for public release; distribution is unlimited 


\section{ABSTRACT:}

Over 90 percent of the coastal wetlands in San Francisco Bay have been lost since the industrial revolution. The U.S. Army Corps of Engineers (USACE) is working with the California State Coastal Conservancy and the San Francisco Bay Conservation and Development Commission (BCDC) to reconstruct wetlands at Hamilton Army Airfield (HAAF) and restore 203 ha of tidal habitat to endangered species such as the clapper rail and the saltmarsh harvest mouse. HAAF has subsided below mean sea level and will require 10 million cu yd of fill material to elevate the site to the point where typical marsh vegetation can colonize and the natural sediment trapping, marsh-building physical dynamics can proceed. Wetlands are believed to be sources of methylmercury (MeHg) production and export, and HAAF represents only 203 ha of the additional 23,300 ha of wetlands to be established around the bay by 2055. Means to mitigate $\mathrm{MeHg}$ magnification in bay aquatic food webs are needed but currently unknown. This interim report describes site-specific information collected in 2003 on the geochemical/geophysical, microbial, predominant plant- and animal-related interactions that affect stabilization and mobilization of $\mathrm{Hg}$ and $\mathrm{MeHg}$ in the sediments/soils of the area.

Total mercury (THg) and MeHg levels were measured in June 2003 in the sediment in relation to depth at intertidal sites at HAAF and the China Camp State Park (as a reference), as well as at inland sites at HAAF and Bel Marin Creek. Other parameters important for the cycling of $\mathrm{Hg}$ and $\mathrm{MeHg}$ in sediments were determined also to establish site-specific relationships between these parameters and $\mathrm{THg}$ and $\mathrm{MeHg}$. The highest $\mathrm{MeHg}$ concentrations (range 0.8-4.4 $\mathrm{mg} \mathrm{g}^{-1} \mathrm{DW}$ ) were found in the upper 2.5-5.1 cm of the cores and levels decreased with depth. THg levels (range 160-550 $\mathrm{ng} \mathrm{g}^{-1}$ ) increased with depth, correlating inversely with $\mathrm{MeHg}$. $\mathrm{MeHg}$ correlated directly with redox potential $\left(\mathrm{E}_{\mathrm{h}}\right)$, total organic carbon, and phosphorus. Net $\mathrm{MeHg}$ production is the result of methylation and demethylation rates in the sediment. Methylation and demethylation rates were determined by on-site incubations of mud- and vegetated-mud cores with stable Hg isotopes at the HAAF and China Camp sites. Methylation rates were $1.44 \mathrm{ng} \mathrm{MeHg} \mathrm{g}^{-1}$ per day in nonvegetated sediments of HAAF. Rates were usually lower in vegetated than in nonvegetated sediments. Rates were usually higher in the light than in darkness. Methylation rates varied with location within the bay on bare and epipelon-vegetated sites and were lower at HAAF than at China Camp. Epipelon is the complex of microalgae, bacteria, and detritus on the sediment surface. Demethylation rates were $1.281 \mathrm{ng} \mathrm{MeHg} \mathrm{g}^{-1}$ per day in nonvegetated sediments at HAAF and $0.78 \mathrm{ng} \mathrm{MeHg} \mathrm{g}{ }^{-1}$ per day at China Camp.

Mean THg concentrations in the macrophytic vegetation, predominated by Spartina foliosa and Salicornia virginica, ranged from 13 to $158 \mathrm{ng} \mathrm{g}^{-1}$ in shoots and from 217 to $297 \mathrm{ng} \mathrm{g}^{-1}$ in roots. Mean MeHg concentration ranged from 0.55 to $4.75 \mathrm{ng} \mathrm{g}^{-1}$ in shoots and from 2.83 to 5.26 in roots. Plant levels usually exceeded those in the sediments in which they rooted. The THg and $\mathrm{MeHg}$ levels in plant detritus were far higher than in live shoots, i.e., by a factor of 5 to 8. Significant levels of $\mathrm{THg}$ and $\mathrm{MeHg}$ were detected in tissues of macrofauna collected at intertidal sites of HAAF and China Camp. MeHg comprised on average 40 percent of THg (range 20-70 percent). Biota to sediment accumulation factors (BAFs) for MeHg ranged from about 3 to 50. Snails were the highest $\mathrm{Hg}$ bioaccumulators. Because the diet of these animals is composed largely of plant material, it is likely that $\mathrm{MeHg}$ in plants represents an important $\mathrm{MeHg}$ source for trophic transfer in the marsh. A preliminary annual $\mathrm{MeHg}$ mass balance for a 203-ha HAAF system indicated a net $\mathrm{MeHg}$ production of $12.8 \mathrm{~kg}$ and $\mathrm{MeHg}$ export in the order of $0.1 \mathrm{~kg}$ with tidal waters to the bay. These values serve as the basis for research hypotheses and future work.

Measures to decrease bioavailability were explored as a management tool. The bioavailability characteristics of $\mathrm{Hg}$ species in HAAF sediments were evaluated experimentally. The MeHg body burdens of the experimentally 2-56 days exposed Macoma nasuta clams were only approximately half of those recorded in clams inhabiting bay edge sediments while elimination was slow, suggesting that exposure periods longer than 56 days are needed for $\mathrm{Hg}$ to approach apparent steady state in clam tissues. Bioavailability decreased more by sediment amendment with granular activated carbon (GAC) than with Kraft-lignin.

A screening-level model pertaining to HAAF (QnD:HAAF) was created to serve as a tool to incorporate ecosystem characteristics and management measures into a user-friendly framework. This model links the spatial components within GIS files to the prevalent abiotic, climatic, and biotic interactions in the ecosystem. It has a simple design and can be upgraded easily. The current QnD:HAAF version 1.0 integrates the field and laboratory data pertaining to HAAF and other related systems. The model was run to simulate two 14-day scenarios, representing the wet and dry season, respectively. Simulated sediment MeHg concentrations exceeded the measured levels while simulated methylation and demethylation rates were on the same order of magnitude as measured values. Elevation proved to be an important factor influencing net $\mathrm{MeHg}$ production. The differences between the simulated and measured $\mathrm{THg}$ and $\mathrm{MeHg}$ levels in sediment and biota may provide leads to identify areas in which more information is needed.

Future research efforts will address processes determining net $\mathrm{MeHg}$ production, atmospheric flux of $\mathrm{Hg}$, exchange of $\mathrm{Hg}$ and $\mathrm{MeHg}$ between sediment and tidal waters, biomagnification of $\mathrm{Hg}$ up relevant aquatic food webs, data integration, and management issues.

DISCLAIMER: The contents of this report are not to be used for advertising, publication, or promotional purposes. Citation of trade names does not constitute an official endorsement or approval of the use of such commercial products. All product names and trademarks cited are the property of their respective owners. The findings of this report are not to be construed as an official Department of the Army position unless so designated by other authorized documents. 


\section{Contents}

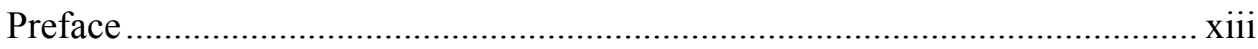

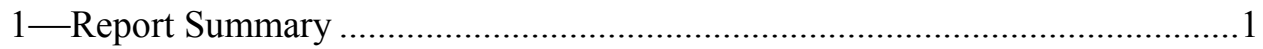

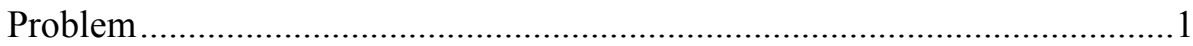

Chapter 3: HAAF Sediment Mercury Pool Sizes and Dynamics in Relation to Primary Producers .............................................................2

Chapter 4: Spatial Distribution and Concentrations of Mercury Species in the Vegetated Marsh Zones..................................................... 3

Chapter 5: Geochemical Characterization of HAAF Sediment Profiles and Mercury Species Levels in Macrofauna ..............................................4

Chapter 6: Bioavailability of Mercury to Benthic Invertebrates: Characterization and Remediation Effects in HAAF Wetland

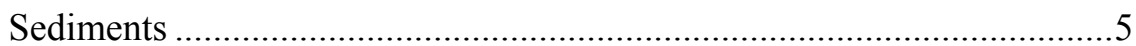

Chapter 7: Integrating Physical, Chemical, and Biological Processes that Drive Mercury and Methylmercury Cycling in San Pablo Bay Salt Marshes into a Screening-Level Model .....................................6

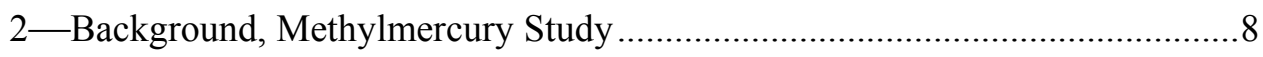

3-HAAF Sediment Mercury Pool Sizes and Dynamics in Relation to

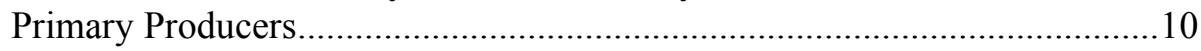

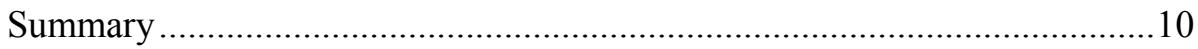

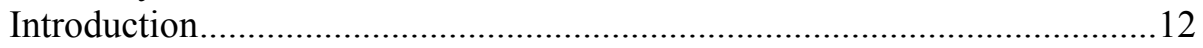

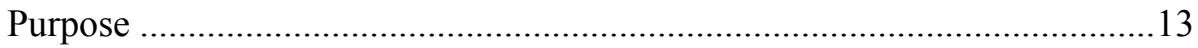

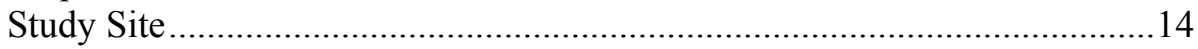

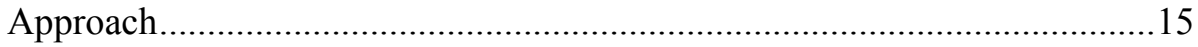

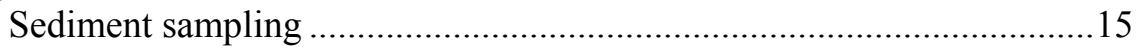

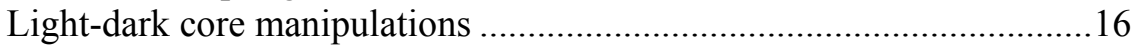

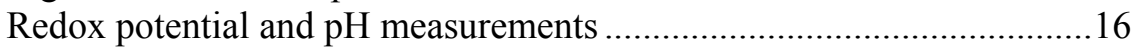

Polar lipid fatty acid analyses..............................................................18

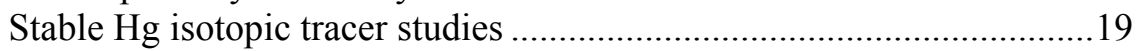

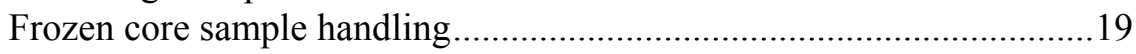

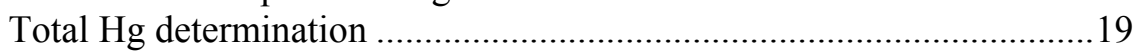

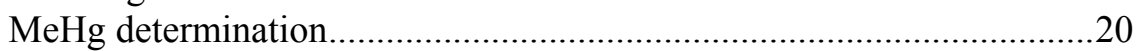

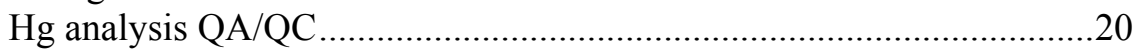

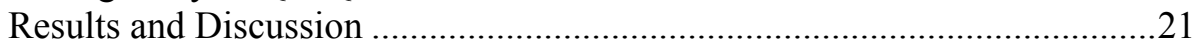

Background information on tidal marsh structure and function...............21

Effects of macrophytes on their rhizospheres .......................................24

Current levels of THg and MeHg in San Francisco Bay wetlands..........25 


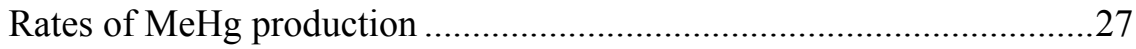

Factors controlling MeHg production .................................................... 31

Initial answers to questions raised at the CALFED Stakeholders

Workshop on Mercury in San Francisco Bay, 8-9 October

2002, Moss Landing Marine Laboratories

4-Spatial Distribution and Concentrations of Mercury Species in the

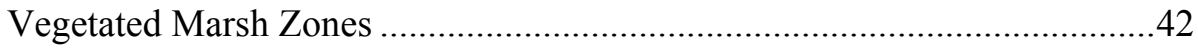

Summary

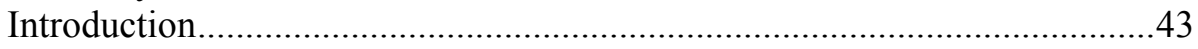

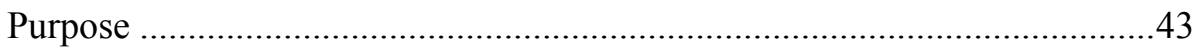

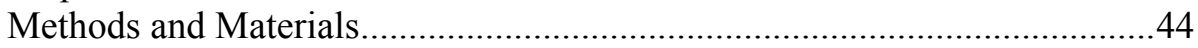

Regrouping of previously collected sediment core data.........................44

Site selection for plant material collection ............................................4

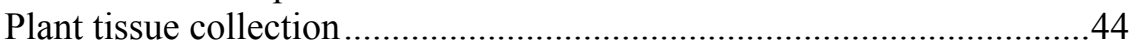

Analysis of plant tissues for total and methylmercury ...........................45

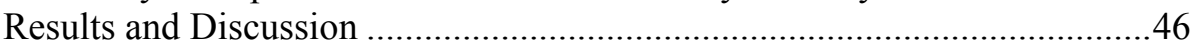

$\mathrm{THg}$ and $\mathrm{MeHg}$ concentrations in nonvegetated and vegetated

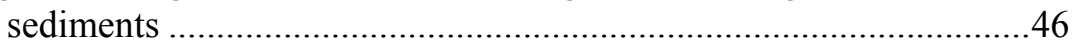

$\mathrm{THg}$ and $\mathrm{MeHg}$ concentrations in plant tissues.....................................47

5- Geochemical Characterization of HAAF Sediment Profiles and Mercury

Species Levels in Macrofauna .....................................................................49

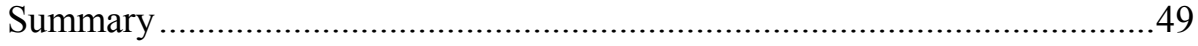

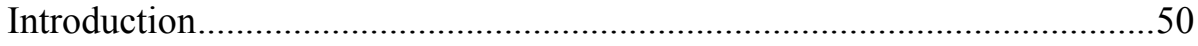

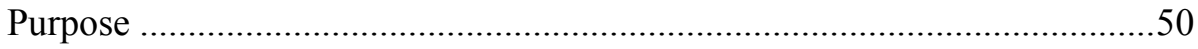

Site Selection for the Collection of Sediment Cores and Macrofauna

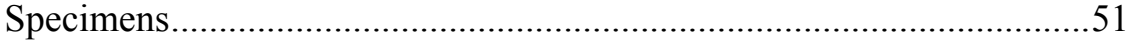

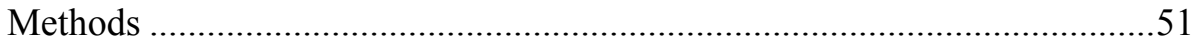

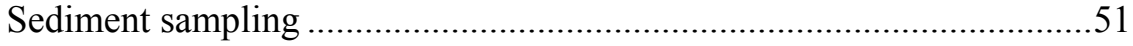

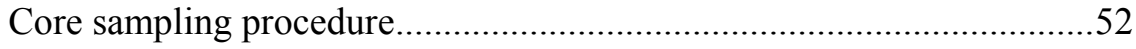

Field measurement of core redox potential and $\mathrm{pH}$................................53

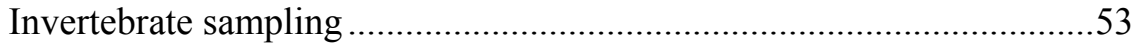

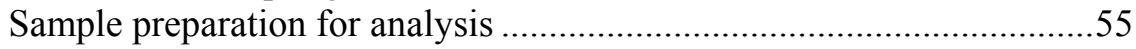

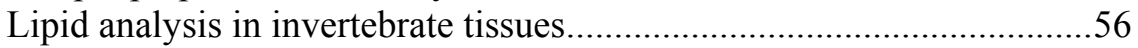

THg determination in sediments and invertebrate tissues ......................57

$\mathrm{MeHg}$ determination in sediments and invertebrate tissues ....................57

Total metals determinations in sediments and invertebrate tissues ..........57

Determination of acid volatile sulfide and simultaneously

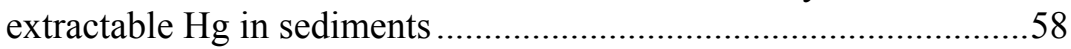

Determination of total organic carbon in sediments..............................58

Determination of particle size distribution in sediments ........................59

Identification of clay minerals in sediments........................................59

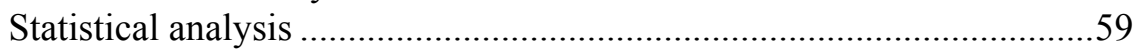

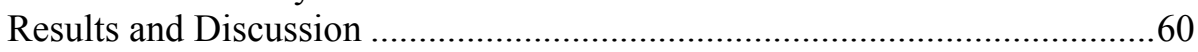

Total $\mathrm{Hg}$ and $\mathrm{MeHg}$ levels in sediments .............................................60

Other parameters important for the cycling of $\mathrm{THg}$ and $\mathrm{MeHg}$ in

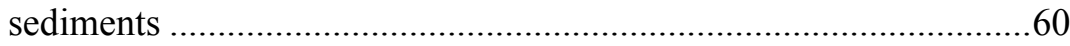

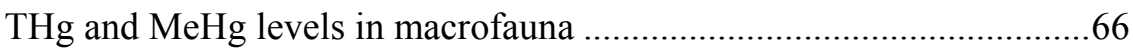


6-Bioavailability of Mercury to Benthic Invertebrates: Characterization and Remediation Effects in HAAF Wetland Sediments.....................................72

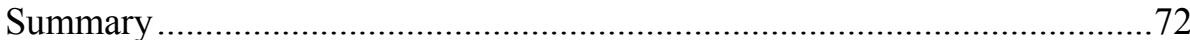

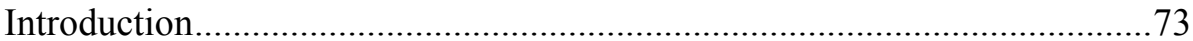

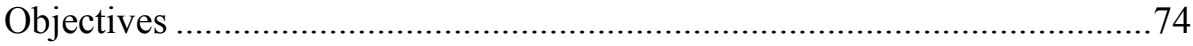

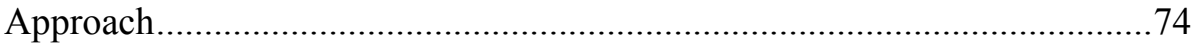

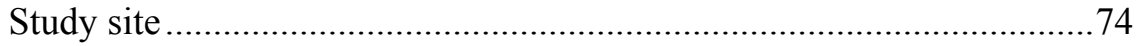

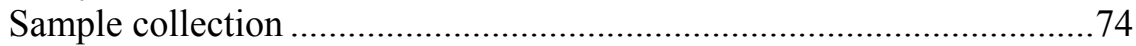

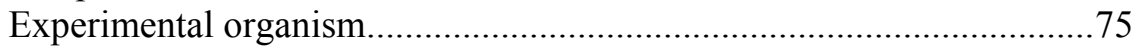

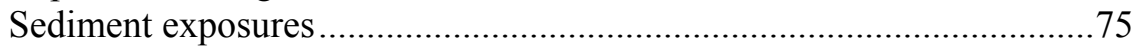

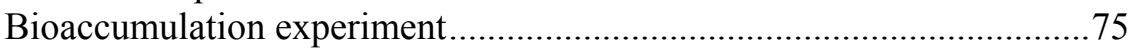

Remediation of $\mathrm{Hg}$ bioavailability experiment .....................................76

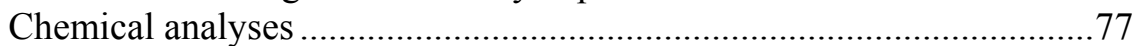

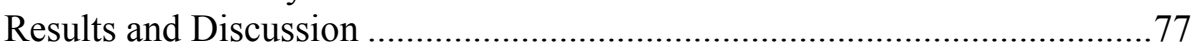

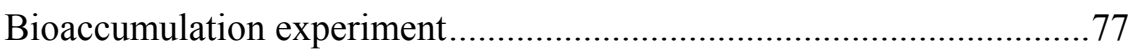

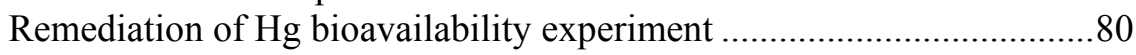

7-Integrating Physical, Chemical, and Biological Processes that Drive Mercury and Methylmercury Cycling in San Pablo Bay Salt Marshes

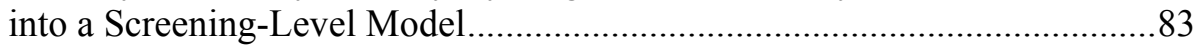

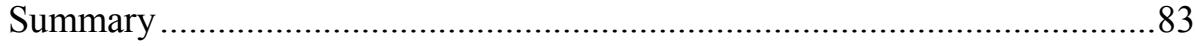

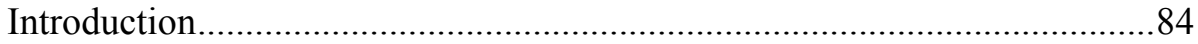

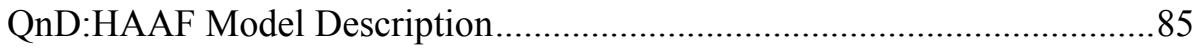

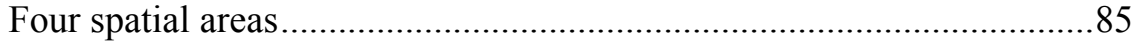

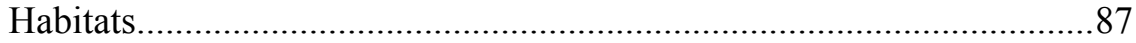

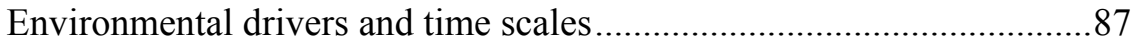

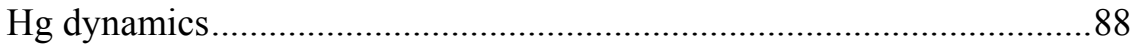

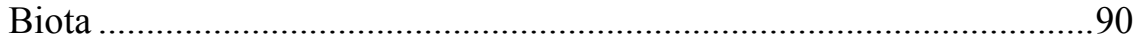

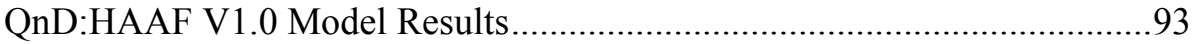

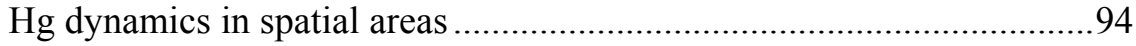

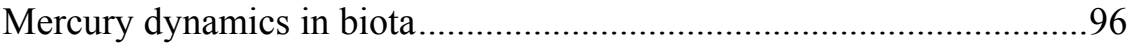

Initial answers to questions raised at the CALFED Stakeholders

Workshop, 8-9 October 2002, Moss Landing Marine

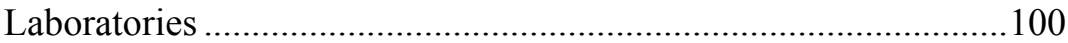

The Way Forward: Recommendations for Research .................................101

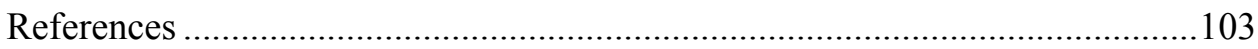

Appendix A: Addendum to Chapter 5 .......................................................... 1

Appendix B: Addendum to Chapter 7 ............................................................... 1

Overview of the QnD Model System..............................................................

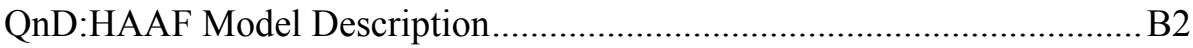

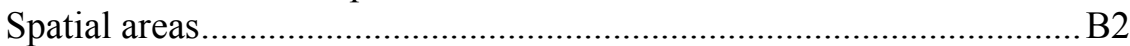

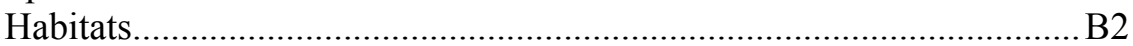

Environmental drivers and time scales.................................................

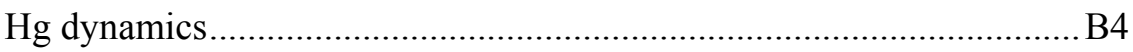

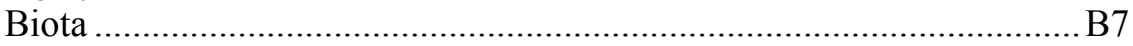

QnD:HAAF Model Results............................................................. B10

Comparison of simulated and measured methylation rates .................. B10 


\section{List of Figures}

Figure 1-1. Location of San Pablo Bay within San Francisco Bay (left) and the location of the HAAF Restoration Site and the China Camp reference site (right)

Figure 2-1. Map of sampling locations HAAF and China Camp (inset)......

Figure 3-1. Study site at the HAAF Wetlands Restoration Site. Location where the measurements were performed marked by arrows

Figure 3-2. Sediment corer constructed to collect 9.5-cm-diam vegetated sediment cores.

Figure 3-3. Administering isotopes to sediment cores and epipelon suspensions

Figure 3-4. Incubation of vegetated cores in light and in darkness (upper); and onsite determinations of redox potential and $\mathrm{pH}$ (lower)

Figure 3-5. Depth profiles of redox potential in nonvegetated and vegetated sediment cores incubated in situ at HAAF in light (L) and in darkness (D)

Figure 3-6. Abiotic conditions determining the various speciations

$$
\text { of } \mathrm{Hg} \text {. }
$$

Figure 3-7. Principal component analysis reveals groupings among triplicate samples of top layers of sediment cores from the indicated vegetative zones. The axes of the plot are the first three principal component factors .34

Figure 4-1. Total sediment $\mathrm{Hg}$ by vegetation zone .....................................46

Figure 4-2. Sediment MeHg by vegetation zone .......................................47

Figure 5-1. Depth profile of in situ redox potential measurements ion sections of replicate cores taken at HAAF Bay Edge (SM-1, SM-10), China Camp (R-44), and Bel Marin (BM-50a). Vertical dashed line is redox cline.

Figure 5-2. Depth profile comparisons and correlations for THg and $\mathrm{MeHg}$ in cores collected at HAAF (SM-1, SM-10) and China Camp (R-44). Mean values and SD (N=5) .55 
Figure 5-3. Depth profile comparisons and correlations for phosphorus $(\mathrm{P})$ and $\mathrm{MeHg}$ in cores collected at HAAF (SM-1, SM-10) and China Camp (R-44). Mean values and $\mathrm{SD}(\mathrm{N}=5)$

Figure 5-4. Depth profile comparisons and correlations for total organic carbon (\%) and $\mathrm{MeHg}$ in cores collected at HAAF (SM-1, SM-10) and China Camp (R-44). Mean values and $\mathrm{SD}(\mathrm{N}=5)$

Figure 5-5. Depth profile comparisons and correlations for redox potential $\left(\mathrm{E}_{\mathrm{h}}\right)$ and $\mathrm{MeHg}$ in cores collected at $\mathrm{HAAF}$ (SM-1, SM-10) and China Camp (R-44). Mean values and $\mathrm{SD}(\mathrm{N}=5)$

Figure 5-6. Depth profile comparisons and correlations for $\mathrm{pH}$ and $\mathrm{MeHg}$ in cores collected at HAAF (SM-1, SM-10) and China Camp (R-44). Mean values and SD (N=5)

Figure 5-7. $\quad \mathrm{E}_{\mathrm{h}}-\mathrm{pH}$ diagram (Mills 1997) populated with data from samples collected at HAAF (SM-1, SM-10) and China Camp (R-44).

Figure 5-8. Invertebrate organisms collected at HAAF and China Camp. Mussels (a), crabs (b), and snails (c).

Figure 5-9. Tissue concentrations of $\mathrm{THg}$ and $\mathrm{MeHg}$ in invertebrates collected at HAAF (SM-1, SM-10) and China Camp (R44). Mean values and SD $(\mathrm{N}=5)$. Matched letters indicate results were significantly different by KruskalWallis one-way ANOVA on Ranks with Dunn's post hoc test $(\mathrm{P}<0.05)$.

Figure 5-10. Bioaccumulation factors (BAFs) for $\mathrm{MeHg}$ (upper) and THg (lower) in invertebrates collected at HAAF (SM-1, SM-10) and China Camp (R-44). Mean values and SD $(\mathrm{N}=5)$. Matched letters indicate results were significantly different by Kruskal-Wallis one-way ANOVA on Ranks with Dunn's post hoc test $(\mathrm{P}<0.05)$.

Figure 6-1. Uptake and elimination of THg from Macoma nasuta exposed to SM-1, SM-10, and R-44 sediments. Dashed line indicates the body burden in field-collected Modiolus sp. (0.12 $\mathrm{ng} \mathrm{kg}^{-1}$, McFarland et al. 2002).

Figure 6-2. Effect of granular activated carbon on sediment pool sizes of legacy ${ }^{202} \mathrm{Hg}$, spikes $\mathrm{Me}^{200} \mathrm{Hg}$, and newly methylated ${ }^{199} \mathrm{Hg}$ .80

Figure 6-3. Effect of granular activated carbon on bioaccumulation of legacy ${ }^{202} \mathrm{Hg}$, spiked $\mathrm{Me}^{200} \mathrm{Hg}$, and newly methylated ${ }^{199} \mathrm{Hg}$ 
Figure 6-4. Effect of granular activated carbon on biota accumulation factor (BAF) for legacy ${ }^{202} \mathrm{Hg}$, spiked $\mathrm{Me}^{200} \mathrm{Hg}$, and newly methylated ${ }^{199} \mathrm{Hg}$.

Figure 7-1. Overview of QnD:HAAF components, drivers, and processes.

Figure 7-2. Spatial units and organisms within QnD:HAAF version 1.0 .86

Figure 7-3. Overview of the QnD:HAAF Hg methylation process ..............88

Figure 7-4. Overview of the QnD:HAAF Hg demethylation process...........89

Figure 7-5. Overview of the QnD:HAAF organism biomass intake process

Figure 7-6. Overview of the QnD:HAAF organism MeHg intake from sediment.

Figure 7-7. Overview of the QnD:HAAF organism MeHg intake from biomass.

Figure 7-8. Simulated MeHg concentrations in surface sediments of four spatial areas.

Figure 7-9. Simulated methylation and demethylation rates in surface sediments of four spatial areas

Figure 7-10. Simulated MeHg export rates from surface areas of four HAAF spatial areas

Figure A-1. Depth profile comparisons and correlations for manganese $(\mathrm{Mn})$ and methylmercury $(\mathrm{MeHg})$ from replicate core samples collected at HAAF (SM-1 \& SM10) and China Camp (R-44). Symbols represent mean of replicate data $(\mathrm{n}=5)$; error bars indicate standard deviation

Figure B-1. Overview of QnD:HAAF objects, drivers, and processes.......B10

Figure B-2. Spatial areas with associated biota within QnD:HAAF version 1.0

Figure B-3. Simplified relationship between local water depth and change in number of hours under water.

Figure B-4. Relationship between hours above and under water, and the hourly change in redox potential B12

Figure B-5. Overview of the QnD:HAAF Hg methylation process B12

Figure B-6. Effect of redox potential on $\mathrm{Hg}$ methylation rate (relative) 
Figure B-7. Overview of the QnD:HAAF MeHg demethylation

process

Figure B-8. Effect of redox potential on methylmercury

demethylation rate (relative)

Figure B-9. QnD:HAAF uptake of biomass ........................................... B14

Figure B-10. QnD:HAAF uptake of $\mathrm{MeHg}$ by organisms directly from sediment

Figure B-11. QnD:HAAF uptake of MeHg through biomass ingestion B15

\section{List of Tables}

Table 3-1. Estimated Rates of Primary Production in California 23

Table 3-2. Characteristics Influencing the Utilization Value of a Source of Primary Production by Macroconsumers within a California Coastal System (Mugu Lagoon; after Onuf (1987))

Table 3-3. Multiple Stable Isotope Ratios (pro mille) of Primary

Producers and Consumers Collected from Two

California Coastal Wetlands

Table 3-4. Depth Profiles of in situ Redox Potential, Measured Just

Outside the Incubated Cores

Table 3-5. Total $\mathrm{Hg}$ and $\mathrm{MeHg}$ Levels in Two Existing Tidal

Marshes Bordering San Francisco Bay, in Sediment, Epipelic Algae, and Marsh Vegetation

Table 3-6. Total $\mathrm{Hg}$ and $\mathrm{MeHg}$ Levels in Sediment and Marsh Vegetation After 5-hr Incubation in Ambient Light Conditions and in Darkness

Table 3-7. Rates of Methylmercury Accumulation and Methylation in Nonvegetated and Vegetated Sediment in Two Existing Tidal Marshes

Table 3-8. Rates of Daily MeHg Degradation Rates in

Nonvegetated and Vegetated Sediment in Two Existing

Tidal Marshes 31

Table 3-9. Rates of Methylation, Demethylation, and

Methylation:Demethylation Ratio in the Sediment of the Existing Marsh Bordering the Two Sites .32 
Table 3-10. Total Microbial Biomass in Sediments, for Which Polar Lipid Fatty Acids Methyl Ester (PLFAME) Content is Taken as a Measure

Table 3-11. Estimated $\mathrm{Hg}$ and $\mathrm{MeHg}$ Standing Stocks of Tidal

Marsh Areas in the Restored HAAF .36

Table 3-12. Estimated Potential MeHg Export of Tidal Marsh Areas in the Restored HAAF, Using Values from this Study 38

Table 3-13. Estimated Potential MeHg Export of Tidal Marsh Areas in the Restored HAAF, Using Values from MarvinDipasquale et al. (2003) for Methylation and Demethylation Rates

Table 3-14. Estimated Potential MeHg Production and Export from Tidal Marsh Areas in San Pablo Bay .41

Table 4-1. Sample Stations in Vegetation Zones.

Table 4-2. $\quad$ THg and MeHg Characteristics in Upper $2 \mathrm{~cm}$ of Sediment in HAAF and China Camp (from McFarland et al. (2002)) .47

Table 4-3. $\quad \mathrm{THg}$ and $\mathrm{MeHg}$ Characteristics in Plant Tissues and Detritus from HAAF, Bel Marin, and China Camp .... .48

Table 5-1. Sample Stations in Vegetation Zones .43

Table 5-2. Total Hg and MeHg Levels in HAAF Bay Edge, China Camp, Bel Marin, and HAAF Inland Soil/Sediment Cores

Table 5-3. Appearance of Seven Visually Different Depth Sections of Upland Salt Marsh Core Sample....

Table 5-4. Sediment Quality Characteristics of HAAF and China Camp Soil/Sediment Cores, Mean (SD).

Table 5-5. $\quad \mathrm{THg}, \mathrm{MeHg}$, Percent $\mathrm{MeHg}$ and Bioaccumulation Factors in Benthic Invertebrates Collected at HAAF and China Camp Sites - June 2003

Table 6-1. Chemical Analyses of Sediment at HAAF (SM-1, SM-

10) and China Camp (R-44)

Table 7-1. Simulated Potential Export and Contribution to the MeHg TMDL 100

Table A1. Sediment Quality Characteristics of Bel Marin and HAAF Upland Soil/Sediment Cores

Table A2. Major and Trace Elements of Bay Edge and Reference Soil/Sediment Cores 
Table A3. Major and Trace Elements of Bel Marin and HAAF Upland Soil/Sediment Cores

Table A4. THg Statistical Analysis by Depth Profile ..............................A3

Table A5. MeHg Statistical Analysis by Depth Profile ...........................A3

Table A6. Statistical Analysis of Phosphorus (P) by Depth Profile...........A4

Table A7. Statistical Analysis of Manganese (Mn) by Depth Profile........A4

Table A8. Statistical Analysis of Total Organic Carbon (\% TOC) by Depth Profile.

Table A9. Statistical Analysis of Redox Potential $\left(E_{h}\right)$ by Depth Profile.

Table A10. Statistical Analysis of Acid-Base Characteristics (pH) by Depth Profile. A6

Table A11. Mineralogy of Six Depth Sections from Composite Cores from HAAF (SM-1) ${ }^{1}$

Table A12. Mineralogy of Six Depth Sections from Composite Cores from HAAF (SM-10) ${ }^{1}$.....

Table A13. Mineralogy of Six Depth Sections from Composite Core Samples from China Camp (R-44) ${ }^{1}$.

Table A14. Mineralogy of Six Depth Sections from Core Samples from Bel Marin (BM-50a) ${ }^{1}$

Table A15. Mineralogy of Seven Depth Sections from Cores from Hamilton Upland Site (SM-10U) ${ }^{1}$ A8

Table B1. Initial Concentrations and Calculated Loads of $\mathrm{Hg}$ and $\mathrm{MeHg}$ for Spatial Areas.

Table B2. Base Hg Methylation Rates for QnD:HAAF Spatial Areas, Under Dry Season, Day-Time, Aerobic Conditions ${ }^{1}$ B16

Table B3. Multiplication Factors Accounting for Seasonal Effects on Methylation Rate ${ }^{1}$.

Table B4. Multiplication Factors for Daylight Effects on Methylation Rate ${ }^{1}$. B16

Table B5. Base Demethylation Rates, ${ }^{1}$ Under Dry Season, DayTime, Aerobic Conditions .

Table B6. Multiplication Factors for Day-Time Light Effects on Demethylation Rate $^{1}$.

Table B7. Initial Numbers of Individuals and Biomass of Biota in QnD:HAAF. 
Table B8. Initial MeHg Concentrations and MeHg Loads of Biota in QnD:HAAF …...........................................................

Table B9. Predators and Prey Demands................................................. B18

Table B10. Predators and Mass Loss Rates to Keep Biomass Pools Constant Over Short Periods .................................................. B18

Table B11. Comparison of Daily Methylation and Demethylation Rates for Salicornia-Vegetated High Marsh ........................... B19 


\section{Preface}

The work reported herein was conducted by the Environmental Laboratory (EL) of the U.S. Army Engineer Research and Development Center (ERDC), Vicksburg, MS.

In March 2003, the U.S. Army Engineer District, San Francisco (CESPN), requested an expansion of pre-construction monitoring of mercury concentrations (total and methylmercury) in sediments and soils of existing wetlands bordering the Hamilton Army Airfield (HAAF) Wetlands Restoration Site on San Pablo Bay, California. The purpose of the expanded activities was to gain site-specific knowledge of the geochemical/geophysical, microbial, predominant plant- and animal-related interactions that affect the stabilization and mobilization of mercury and methylmercury in the sediments/soils of the area.

The current report describes research conducted upon this request and a firstgeneration, site-specific, screening-level model created for estimating mercury and methylmercury mobility during wetlands reconstruction (all data pertaining to 2003).

The project leader of this work was initially Dr. V. F. McFarland, Environmental Risk Assessment Branch (ERAB), succeeded by Dr. H. L. Fredrickson, Environmental Processes Branch (EPB), both of the Environmental Processes and Engineering Division (EPED), EL. Principal investigators of the multidisciplinary team were: Dr. H. L. Fredrickson, Dr. Elly P. H. Best, and Dr. H. Hintelmann (Trent University, Department of Chemistry, Peterborough, Ontario, Canada) for the work on HAAF sediment pool sizes and dynamics in relation to primary producers; Mr. Richard A. Price, ERAB, for the work on spatial distribution and concentration of mercury species in the vegetated zones; Dr. R. P. Jones, Dr. A. J. Bednar, Dr. V. F. McFarland, and Mr. C. H. Lutz, ERAB, for the work on geochemical characterization of HAAF sediment profiles and mercury levels in macrofauna; Dr. R. N. Millward, Analytical Services, Inc., Vicksburg, MS, and Dr. G. R. Lotufo, ERAB, for the work on the bioavailability of mercury to benthic invertebrates; Dr. G. A. Kiker, ERAB, for the screeninglevel modeling work (QnD:HAAF). Dr. E. P. H. Best served as guest editor of this report. Dr. G. A. Ray, Environmental Stewardship and Engineering Division, EL, participated in the field collections and identification of the invertebrates.

Special thanks go to the following Corps of Engineers personnel who gave generously of their time and expertise to review the drafts of this report: 
Dr. W. Brostoff for his comments on the third draft, and Drs. E. A. Ferguson and T. M. Sobecki for their reviews of the final draft.

The study was conducted under the direct supervision of Dr. Richard E. Price, Chief, EPED, and under the general supervision of Dr. Edwin A. Theriot, Director, EL.

At the time of publication of this report, COL James R. Rowan, EN, was Commander and Executive Director of ERDC, and Dr. James R. Houston was Director. 


\section{Report Summary}

\section{Problem}

Long-term goals for San Francisco Bay development include extensive wetland restoration. The current wetlands bordering San Pablo Bay are to be increased from 16,200 to 42,525 ha by the year 2055 (San Francisco Bay Area Wetlands Ecosystem Goals Project 1999). Dikes currently protect most of the areas targeted for restoration. Drying and oxidation of the soils on the landward side of the dikes has resulted in subsidence such that current soil elevations are often meters below the mean tide level. Breaching the dikes would result in lakes, not wetlands. Considerable amounts of fill material are required to raise the elevation of subsided areas to a level that would support aquatic macrophytes that would in turn trap sediments required to sustain the elevation of the wetland. For example, the Hamilton Army Airfield site will require approximately 10.6 million cubic yards of material. Sediments derived from operations and maintenance of navigation channels in the bay could be used for this purpose. This beneficial use of local dredged materials would not only save the Government the cost of obtaining other fill material; it would also save the cost of transporting the material to more distal disposal sites.

The high current levels of mercury in the San Francisco Bay fishery complicate this potential "win-win" situation. The San Francisco Bay watershed is impacted by the legacy of mercury mines in the coastal range and placer gold mining in much of the Sierra Nevada watershed. Wetlands, particularly intertidal wetlands, are notorious for converting mercury to methylmercury.

Methylmercury is a potent neurotoxin that efficiently biomagnifies in many aquatic food webs. In this context, the immediate concern of the U.S. Army Corps of Engineers focuses on the use of mercury-containing dredged material for the restoration of wetlands. However, the level of mercury in these dredged materials will be generally typical of that found in the majority of the bay sediments. The larger environmental issue affecting the use of dredged material for wetland restoration becomes the contribution of bay salt marshes to mercury in the bay fishery, no matter the source of the mercury.

Most of the work in this interim report was designed to address consensus technical questions formulated at the CALFED Stakeholders' Workshop on Mercury in San Francisco Bay, held 8-9 October 2002 at Moss Landing Marine Laboratories. These included: 
a. What are the present levels of MeHg in SF Bay wetlands with respect to biota, sub-habitats, and location within the bay?

b. What are the rates of $\mathrm{MeHg}$ production?

c. What factors control MeHg production? Can these be managed?

d. Are some wetlands larger mercury exporters than others?

e. Can we model/predict the effects of wetland restoration on $\mathrm{MeHg}$ production and export?

A site map is provided in Figure 1-1.

\section{Chapter 3: HAAF Sediment Mercury Pool Sizes and Dynamics in Relation to Primary Producers}

An exploratory field study was conducted to: (1) measure total $\mathrm{Hg}$ and $\mathrm{MeHg}$ levels concurrently in sediments from low marsh (mud), middle marsh (Spartina foliosa), high marsh (Salicornia virginica), and epipelon-vegetated mud from different locations in and adjacent to HAAF; (2) determine rates of $\mathrm{Hg}^{2+}$ methylation and $\mathrm{MeHg}$ demethylation potential in sediments from low marsh (mud), middle marsh (Spartina foliosa), high marsh (Salicornia virginica), and epipelonvegetated mud; and (3) explore the following factors potentially influencing methylation and demethylation rates: illumination, plant species, redox potential and $\mathrm{pH}$, and composition of the microbial community. Epipelon is the complex of microalgae, bacteria, and detritus on the sediment surface.

Samples were collected and incubated during the period 9-11 June 2003, i.e. in the dry season, in two tidal marshes, a marsh bordering the HAAF, and a reference marsh. The test site was situated at the HAAF Bay Edge and the reference site in the China Camp State Park wetland. Where possible, locations within each site were chosen to represent the low marsh (mud), middle marsh (Spartina foliosa), and high marsh (Salicornia virginica).

Mud- and vegetated-mud cores were incubated with stable $\mathrm{Hg}$ isotopes on site, and redox potential and $\mathrm{pH}$ in the incubated cores were recorded. After incubation, the cores were flash-frozen and shipped to the laboratory for further analyses.

Mean MeHg concentrations in sediments were on the same order of magnitude at HAAF and China Camp, and ranged from 1.11 to $2.39 \mathrm{ng} \mathrm{g}^{-1} \mathrm{DW}$. Mean $\mathrm{MeHg}$ concentrations in the macrophytes ranged from $1.01 \mathrm{ng} \mathrm{g}^{-1} \mathrm{DW}$ in $S$. foliosa stems to $5.59 \mathrm{ng} \mathrm{g}^{-1} \mathrm{DW}$ in $S$. foliosa roots. Plant levels usually exceeded those in the sediments in which they rooted, particularly when incubated under ambient irradiance.

Net $\mathrm{MeHg}$ production is the result of methylation and demethylation rates in the sediment. Methylation rates were $1.44 \mathrm{ng} \mathrm{MeHg} \mathrm{g}^{-1} \mathrm{DW}$ per day in 
nonvegetated sediments of HAAF. Rates were usually lower in vegetated than in nonvegetated sediments. Rates were usually higher in the light than in darkness. Methylation rates varied with location within the bay on bare and epipelonvegetated sites and were lower at HAAF than at China Camp. Demethylation rates were $1.281 \mathrm{ng} \mathrm{MeHg} \mathrm{g}^{-1} \mathrm{DW}$ per day in nonvegetated sediments at HAAF and $0.78 \mathrm{ng} \mathrm{MeHg} \mathrm{g}^{-1} \mathrm{DW}$ per day at China Camp.

Methylation and demethylation rates appear to be higher in the sediment surface layers than in deeper layers. In the surface layers, the microbial biomass is also highest, and the composition of the microbial communities is strongly influenced by the presence/absence of vegetation, and by the vegetating species (epipelon, S. foliosa, S. virginica). The largest variations in redox potential occur in the surface layer due to tidal inundation and plant-sediment interactions.

Mass balance and export estimations are speculative, but begin to frame the problem and help identify critical information gaps. They are not meant for TMDL use but for the purpose of identifying current knowledge gaps that prevent the calculation of meaningful TMDLs. Based on the assumptions detailed in this report, the initial estimated annual net $\mathrm{MeHg}$ production of the $2005 \mathrm{HAAF}$ system is $12.8 \mathrm{~kg}$. The annual export of $\mathrm{MeHg}$ with tidal waters to the bay is projected to be on the order of $0.1 \mathrm{~kg}(0.8$ percent of the $\mathrm{MeHg}$ in the top $5 \mathrm{~cm}$ of sediment). These values will serve as the basis for research hypotheses for future work. Although the levels of $\mathrm{MeHg}$ in salt marsh standing biomass are higher than those in the sediment, the mass of this biomass is much lower than that of the 0 - to 5-cm sediment. The MeHg trophic transfer mechanisms and efficiencies from salt marsh biomasses into bay fisheries are important but unknown. Also important, but unknown, are the roles that the atmosphere serves as a source of bioavailable mercury and as a sink for mercury volatilized from aquatic systems.

The limited availability of data on $\mathrm{Hg}$ and $\mathrm{MeHg}$ cycling in salt marshes and the large variability in the existing data cause large uncertainties in projections using these data. To decrease this uncertainty, key sensitive parameters were selected on which future efforts should focus. These include collecting more data on methylation and demethylation rates of bare and vegetated sediments using the best techniques, measuring the atmospheric flux of mercury to/from the salt marsh, measuring the exchange of $\mathrm{Hg}$ and $\mathrm{MeHg}$ between sediment and tidal waters, and determining the mechanisms and efficiencies of $\mathrm{MeHg}$ transfer in relevant aquatic food webs originating from the dominant primary producers.

\section{Chapter 4: Spatial Distribution and Concentrations of Mercury Species in the Vegetated Marsh Zones}

The purpose of this study was to determine a tentative relationship between marsh zones and $\mathrm{THg}$ and $\mathrm{MeHg}$ levels in the sediments, and assess the $\mathrm{THg}$ and $\mathrm{MeHg}$ concentrations in live and dead plant materials collected from these zones.

To accomplish this, a tentative relationship between marsh zonation and $\mathrm{THg}$ or $\mathrm{MeHg}$ concentrations in the sediment was explored by regrouping previously 
collected data on $\mathrm{Hg}$ species concentrations in surficial sediment cores according to vegetation zone, and calculating mean values for each zone. Furthermore, tissues from live plant shoots and of plant detritus were collected from as many zones as possible, and analyzed for mercury species. The following zones were distinguished: nonvegetated mudflats, $S$. foliosa-vegetated tidal marsh, $S$. virginica-vegetated upper marsh, and upland-seasonally flooded wetland.

The THg and MeHg levels in the surficial sediments of the marsh zones varied by zone. The mean $\mathrm{THg}$ concentrations in the surface sediments decreased in the order Low marsh $>$ High marsh $>$ Diked high marsh $>$ Mudflat. No distinct effect of dry and wet season on THg concentration was noted. Mean THg concentrations in the dry season were: Low marsh $346 \mathrm{ng} \mathrm{g}^{-1} \mathrm{DW}$, High marsh $292 \mathrm{ng} \mathrm{g}^{-1}$ DW, Diked high marsh $261 \mathrm{ng} \mathrm{g}^{-1}$ DW, Mudflat $236 \mathrm{ng} \mathrm{g}^{-1}$ DW.

Mean $\mathrm{MeHg}$ concentrations increased in the sediments of all zones during the wet season except in the mudflats. Mean $\mathrm{MeHg}$ concentrations decreased in the order High marsh 7.29 $\mathrm{ng} \mathrm{g}^{-1} \mathrm{DW}>$ Low marsh $5.17 \mathrm{ng} \mathrm{g}^{-1} \mathrm{DW}>$ Diked high marsh $1.82 \mathrm{ng} \mathrm{g}^{-1} \mathrm{DW}>$ Mudflat $0.73 \mathrm{ng} \mathrm{g}^{-1} \mathrm{DW}$.

In plant shoots, the mean concentrations of THg ranged from 14 to $25 \mathrm{ng} \mathrm{g}^{-1}$ $\mathrm{DW}$, and of MeHg from 0.17 to $0.96 \mathrm{ng} \mathrm{g}^{-1} \mathrm{DW}$ in S. foliosa and S. virginica. $\mathrm{THg}$ and $\mathrm{MeHg}$ levels in the plant shoots did not appear to be related to species or zone, but the number of locations sampled was small. The $\mathrm{THg}$ and $\mathrm{MeHg}$ levels in plant detritus were far higher than in live shoots, i.e., by a factor of 5 to 8 .

\section{Chapter 5: Geochemical Characterization of HAAF Sediment Profiles and Mercury Species Levels in Macrofauna}

This chapter details the results obtained from a field study conducted in June 2003. The purpose of this effort was to measure THg and $\mathrm{MeHg}$ levels in the sediment in relation to depth at intertidal sites at HAAF and China Camp State Park (as a reference), as well as inland sites at HAAF and Bel Marin Creek. Other parameters important for the cycling of $\mathrm{Hg}$ and $\mathrm{MeHg}$ in sediments were also determined with the goal of establishing site-specific relationships between these parameters and $\mathrm{THg}$ and $\mathrm{MeHg}$. Finally, $\mathrm{Hg}$ and $\mathrm{MeHg}$ were measured in macrofauna collected at the above-mentioned intertidal sites for the purpose of calculating site-specific, biota-sediment bioaccumulation factors (BAFs).

For sediments, the highest $\mathrm{MeHg}$ concentrations were found in the upper 2.5 to $5.1 \mathrm{~cm}$ of the cores, and levels decreased with depth, suggesting that conditions for the methylation of $\mathrm{Hg}$ are most favorable near the surface. $\mathrm{THg}$ levels increased with depth, correlating inversely with $\mathrm{MeHg}$. The significance of this is unclear, but may suggest a net loss of mercury from the surface through volatilization or surface runoff/tidal transport of $\mathrm{MeHg}$ from the sediment surface. $\mathrm{MeHg}$ correlated directly with redox potential $\left(\mathrm{E}_{\mathrm{h}}\right)$, total organic carbon (TOC), and phosphorus (P), suggesting that these parameters were associated with $\mathrm{MeHg}$ levels in HAAF marsh sediment. The predicted influence of $\mathrm{E}_{\mathrm{h}}$ and 
$\mathrm{pH}$ on the bioavailability of $\mathrm{Hg}$ is consistent with the observed $\mathrm{MeHg}$ profile with more positive $E_{h}$ values representing oxic conditions near the surface favoring $\mathrm{Hg}$ in the bioavailable $\mathrm{Hg}^{0}$ state, and more negative $\mathrm{E}_{\mathrm{h}}$ values (anoxic) at increasing depths favoring formation of non-bioavailable $\mathrm{HgS}$.

For macrofauna, significant levels of $\mathrm{THg}$ and $\mathrm{MeHg}$ were detected in tissues of animals collected at intertidal sites at HAAF and China Camp, suggesting that both $\mathrm{THg}$ and $\mathrm{MeHg}$ are available for uptake. $\mathrm{MeHg}$ comprised on average 40 percent of $\mathrm{THg}$ (range 20 to 70 percent), indicating that a significant portion of the invertebrate $\mathrm{THg}$ body burden is in the form of $\mathrm{MeHg}$. Calculated BAFs (greater than 1) suggest that $\mathrm{MeHg}$ has a strong tendency toward bioaccumulation, and $\mathrm{BAFs}$ for $\mathrm{MeHg}$ ranged from about 3 to 50. Snails were the highest $\mathrm{Hg}$ bioaccumulators. Because the diet of these animals is composed largely of plant material, it is likely that $\mathrm{MeHg}$ in plants represents an important $\mathrm{MeHg}$ source for terrestrial trophic transfer.

\section{Chapter 6: Bioavailability of Mercury to Benthic Invertebrates: Characterization and Remediation Effects in HAAF Wetland Sediments}

Many studies have identified the potential adverse effects of bioaccumulation and biomagnification of $\mathrm{Hg}$. As such, it is imperative that the bioavailability of $\mathrm{Hg}$, and in particular the $\mathrm{MeHg}$ species, be ascertained as part of any assessment of environmental and human risk. The study incorporated two research goals, (1) to establish baseline bioaccumulation of $\mathrm{Hg}$ and $\mathrm{MeHg}$ in a representative and locally abundant benthic organism, the bent-nosed clam Macoma nasuta, and (2) to determine whether $\mathrm{Hg}$ uptake might be reduced by the addition of $\mathrm{Hg}$ sorbing materials into the sediment. In the bioaccumulation experiment the uptake and elimination of $\mathrm{THg}$ and $\mathrm{MeHg}$ were measured in M. nasuta exposed to HAAF Bay Edge (SM-1 and SM-10) and the reference site China Camp State Park (R44) cores. A similar pattern of THg temporal bioaccumulation and similar final $\mathrm{THg}$ body burden at termination of the uptake phase of the experiment suggest that the bioavailability of $\mathrm{THg}$ was similar at all sites. The uptake phase was characterized by a rapid increase in body burden followed by a slower increase, whereas during the elimination phase a rapid decrease in body burden was followed by a slower decrease. Overall, the bioaccumulation study indicated that the elimination of $\mathrm{Hg}$ is very slow in benthic clams, as the apparent steadystate body burden was not reached following a 56-day exposure. The body burdens of the experimentally exposed clams were only approximately half of those recorded in clams inhabiting Bay Edge sediments, further suggesting that exposure periods longer than 56 days are needed for $\mathrm{THg}$ to approach apparent steady-state in clam tissues. The tissue $\mathrm{MeHg}$ concentrations varied considerably between replicates throughout the exposure, hampering the observation of temporal changes in body burden during the uptake and elimination phases of the bioaccumulation experiment.

In the remediation study, sediment from the SM-10 site was used to test the effects of granular activated carbon (GAC) and sulfonated Kraft lignin on speciation and bioaccumulation of $\mathrm{THg}$ and $\mathrm{MeHg}$ in 56-day exposures using 
M. nasuta. Results were mixed but promising. GAC significantly decreased the bioaccumulation of spiked $\mathrm{MeHg}$, and $\mathrm{MeHg}$ methylated from spiked $\mathrm{Hg}^{2+}$, despite the higher concentration of those substances in the amended sediment, whereas it did not affect the bioaccumulation of legacy $\mathrm{Me}^{202} \mathrm{Hg}$. It is suggested that GAC was more effective in reducing the uptake of spiked $\mathrm{Hg}$ species, since these were more labile and hence were freer to associate with GAC particles. In contrast, ambient $\mathrm{Hg}$ is more likely to be in closer association with sediment ligands, and hence would be more refractile and less available for contact with GAC. It is suggested that further experiments should contact sediment with GAC for periods longer than 16 days, to address efficacy of GAC on ambient $\mathrm{Hg}$ availability. Sulfonated Kraft lignin was extremely soluble in seawater, suggesting a short theoretical contact time with $\mathrm{Hg}$ in the sediments and raising issues of transportation of any lignin-sorbed $\mathrm{Hg}$ out of the system. Therefore, lignin was eliminated as a viable sorption candidate.

\section{Chapter 7: Integrating Physical, Chemical, and Biological Processes that Drive Mercury and Methylmercury Cycling in San Pablo Bay Salt Marshes into a Screening-Level Model}

The Questions and Decisions ${ }^{\mathrm{TM}}(\mathrm{QnD})$ : screening model system was created to provide an effective tool to incorporate ecosystem and management issues into a user-friendly framework. The QnD model links the spatial components within GIS files to the prevalent abiotic, climatic, and biotic interactions in an ecosystem. QnD has a simple design and can be upgraded easily. This modeling approach has been applied to the HAAF wetland restoration project (QnD: HAAF). The purpose of the current QnD:HAAF version 1.0 is to integrate the field and laboratory data detailed in the preceding chapters of this report. QnD: HAAF is being applied in an iterative, interactive manner to identify critical abiotic and biotic drivers of salt marsh $\mathrm{Hg}$ and $\mathrm{MeHg}$ cycling and guide subsequent work on HAAF and San Francisco Bay salt marshes. It is planned to incorporate and link scientific, economic, and social issues in a manner that enables the evaluation of their relative impacts through scenario projections. As further learning occurs, those drivers that are shown to be important can be explored and subsequently expanded, and those that are judged unimportant can be discarded. Whereas these changes would require substantial code rewriting of other models, they are rapidly made in QnD.

The QnD:HAAF v1.0 is composed of four spatial areas (High Salicorniavegetated Marsh, Mid Spartina-vegetated Marsh, Mud Flat, and Sub Tidal), three drivers (day-time light, dry and wet season, and tide-dependent redox potential), and two processes (methylation and demethylation). Biota are represented by typical plant and animal species.

Although QnD:HAAF v1.0 development is based for only 10 percent on concepts and literature data, and for 90 percent on data measured in one year only, i.e. 2003, the model results have generated several interesting points for discussion and further exploration.Two 14-day scenarios were simulated, i.e., one 
scenario representing the wet season (1-14 February 2004) and one scenario representing the dry season (1-14 June 2003). Simulated MeHg levels in biota indicated a significant bioaccumulation potential from lower to higher trophic levels, regardless of season. Elevation was an important factor influencing net $\mathrm{MeHg}$ production. Simulated MeHg concentrations in the sediment exceeded the measured levels, whereas simulated methylation and demethylation rates were on the same order of magnitude as measured values. The difference between the simulated and measured $\mathrm{Hg}$ levels in the sediment and biota can provide a first estimate of the magnitude of the HAAF Hg export term. Current work plans focus on validating the value of the HAAF $\mathrm{Hg}$ export term and the processes by which this export is realized.

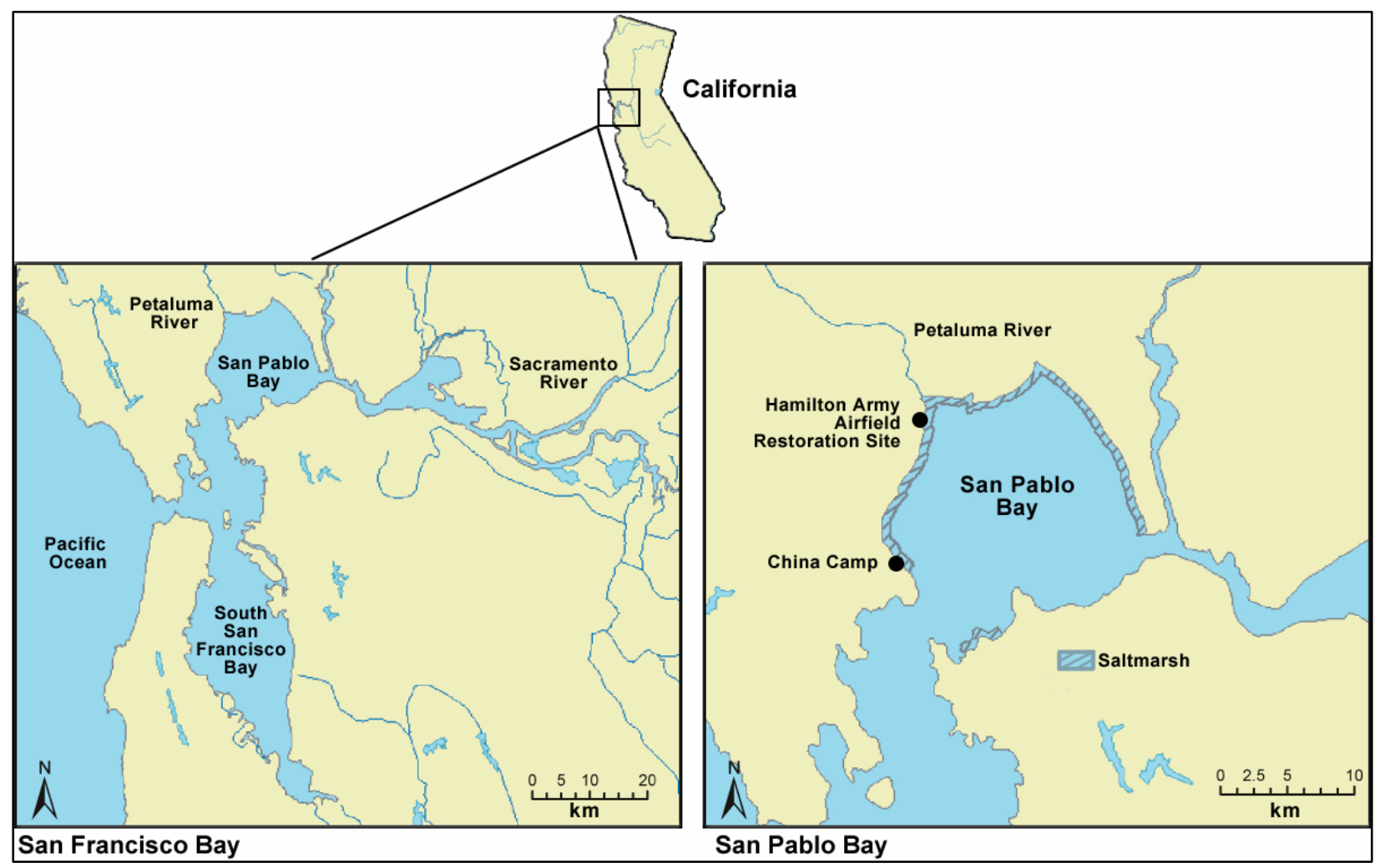

Figure 1-1. Location of San Pablo Bay within San Francisco Bay (left) and location of the HAAF Restoration Site and the China Camp reference site (right) 


\section{Background, Methylmercury Study}

In March 2003, the U.S. Army Engineer District, San Francisco (CESPN) requested an expansion of pre-construction monitoring of mercury concentrations (total and methylmercury) in sediments and soils of existing wetlands bordering the Hamilton Army Airfield (HAAF) Wetlands Restoration Site on San Pablo Bay, California. Sampling locations are shown in Figure 2-1. The purpose of the expanded activities was to gain site-specific knowledge of the geochemical/ geophysical, microbial, predominant plant- and animal-related interactions that affect the stabilization and mobilization of mercury and methylmercury in the sediments/soils of the area. Based on these results, a first-generation, sitespecific, screening-level model was created for estimating mercury and methylmercury mobility during wetlands reconstruction.

The potential for methylation of mercury in sediments and soils of tidal marsh and seasonal wetlands bordering the HAAF Wetlands Restoration Site was assessed by same-sample analysis for total mercury (THg) and monomethylmercury $\left(\mathrm{CH}_{3} \mathrm{Hg}^{+}, \mathrm{MMHg}\right.$, or $\mathrm{MeHg}$ ) during the dry season (McFarland et al. 2002, and appendices therein) and during the wet season in 2002-2003 (McFarland et al. 2002, 2003a). The surficial $1-2 \mathrm{~cm}$ of sediments at 60 sites (replicated five times) divided among seven locations were sampled. Results served as the basis for selection of sites for intensive study as described in the HAAF Mercury Characterization Project Management Plan (MacFarland et al. 2003b). The results of the subsequent feasibility studies, conducted during 2003 and largely interpreted during 2004, are described in the current report. 


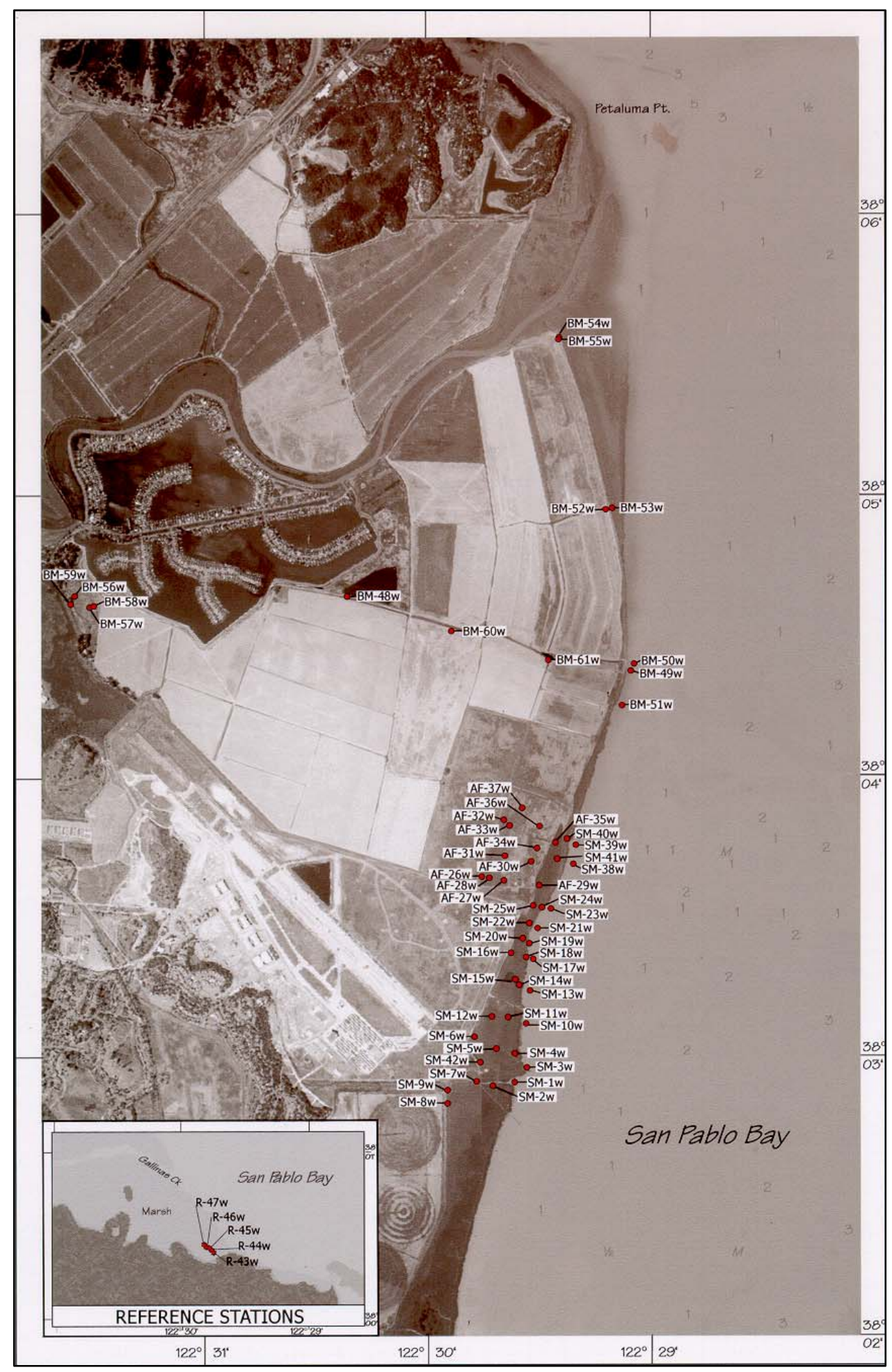

Figure 2-1. Map of sampling locations HAAF and China Camp (inset) 


\section{HAAF Sediment Mercury Pool Sizes and Dynamics in Relation to Primary Producers $^{1}$}

\section{Summary}

An exploratory field study was conducted to: (1) measure total $\mathrm{Hg}$ and $\mathrm{MeHg}$ levels concurrently in sediments from low marsh (mud), middle marsh (Spartina foliosa), high marsh (Salicornia virginica), and epipelon-vegetated mud from different locations in and adjacent to HAAF; (2) determine rates of $\mathrm{Hg}^{2+}$ methylation and $\mathrm{MeHg}$ demethylation potential in sediments from low marsh (mud), middle marsh (Spartina foliosa), high marsh (Salicornia virginica), and epipelonvegetated mud; and (3) explore the following factors potentially influencing methylation and demethylation rates: illumination, plant species, redox potential and $\mathrm{pH}$, and composition of the microbial community. Epipelon is the complex of microalgae, bacteria, and detritus on the sediment surface.

Samples were collected and incubated during the period 9-11 June 2003, i.e. in the dry season, in two tidal marshes, a marsh bordering the HAAF, and a reference marsh. The test site was situated at the HAAF Bay Edge and the reference site in the China Camp State Park wetland. Where possible, locations within each site were chosen to represent the low marsh (mud), middle marsh (Spartina foliosa), and high marsh (Salicornia virginica).

Mud- and vegetated-mud cores were incubated with stable $\mathrm{Hg}$ isotopes on site, and redox potential and $\mathrm{pH}$ in the incubated cores were recorded. After incubation, the cores were flash-frozen and shipped to the laboratory for further analyses.

Mean $\mathrm{MeHg}$ concentrations in sediments were on the same order of magnitude at HAAF and China Camp, and ranged from 1.11 to $2.39 \mathrm{ng} \mathrm{g}^{-1} \mathrm{DW}$. Mean $\mathrm{MeHg}$ concentrations in the macrophytes ranged from $1.01 \mathrm{ng} \mathrm{g}^{-1} \mathrm{DW}$ in

\footnotetext{
${ }^{1}$ Point of contact for this chapter is Elly P. H. Best, U.S. Army Engineer Research and Development Center, Environmental Laboratory, Vicksburg, MS, USA, Ph: 601-6344246; Email: elly.p.best@erdc.usace.army.mil.
} 
S. foliosa stems to $5.59 \mathrm{ng} \mathrm{g}^{-1} \mathrm{DW}$ in $S$. foliosa roots. Plant levels usually exceeded those in the sediments in which they rooted, particularly when incubated under ambient irradiance.

Net $\mathrm{MeHg}$ production is the result of methylation and demethylation rates in the sediment. Methylation rates were $1.44 \mathrm{ng} \mathrm{MeHg} \mathrm{g}^{-1} \mathrm{DW}$ per day in nonvegetated sediments of HAAF. Rates were usually lower in vegetated than in nonvegetated sediments. Rates were usually higher in the light than in darkness. Methylation rates varied with location within the Bay on bare and epipelonvegetated sites, and were lower at HAAF than at China Camp. Demethylation rates were $1.201 \mathrm{ng} \mathrm{MeHg} \mathrm{g}^{-1} \mathrm{DW}$ per day in nonvegetated sediments. Rates were equal or lower in vegetated sediments at HAAF and $0.70 \mathrm{ng} \mathrm{MeHg} \mathrm{g}^{-1} \mathrm{DW}$ per day at China Camp. Among all sediments studied, the epipelon-vegetated sediment exhibited the highest potential for net $\mathrm{MeHg}$ production, with a methylation:demethylation ratio of 12 . Bare and $S$. foliosa -vegetated sediment had the lowest ratio, i.e. of 2 , whereas $S$. virginica-vegetated sediment had a ratio of 7 .

Methylation and demethylation rates appear to be higher in the sediment surface layers than in deeper layers. In the surface layers, the microbial biomass is also highest, and the composition of the microbial communities is strongly influenced by the presence/absence of vegetation, and by the vegetating species (epipelon, S. foliosa, S. virginica). The largest variations in redox potential occur in the surface layer due to tidal inundation and plant-sediment interactions.

The mass balance and export estimations of the authors are speculative, but begin to frame the problem and help identify critical information gaps. They are not meant for TMDL use but for the purpose of identifying current knowledge gaps that prevent the calculation of meaningful TMDLs. Based on the assumptions detailed in this report, our initial estimated annual net $\mathrm{MeHg}$ production of the $2005 \mathrm{HAAF}$ system is $12.8 \mathrm{~kg}$. The annual export of $\mathrm{MeHg}$ with tidal waters to the bay is projected to be on the order of $0.1 \mathrm{~kg}(0.8$ percent of the $\mathrm{MeHg}$ in the top $5 \mathrm{~cm}$ of sediment). These values will serve as the basis for research hypotheses for future work. Although the levels of $\mathrm{MeHg}$ in salt marsh standing biomass are higher than those in the sediment, the mass of this biomass is much lower than that of the $0-$ to $5-\mathrm{cm}$ sediment. The MeHg trophic transfer mechanisms and efficiencies from salt marsh biomasses into bay fisheries are important but unknown. Also important but unknown are the roles that the atmosphere serves as a source of bioavailable mercury and as a sink for mercury volatilized from aquatic systems.

The limited availability of data on $\mathrm{Hg}$ and $\mathrm{MeHg}$ cycling in salt marshes and the large variability in the existing data cause large uncertainties in projections using these data. To decrease this uncertainty, key sensitive parameters were slected on which future efforts should focus. These include collecting more data on methylation and demethylation rates of bare and vegetated sediments using the best techniques, measuring the atmospheric flux of mercury to/from the salt marsh, measuring the exchange of $\mathrm{Hg}$ and $\mathrm{MeHg}$ between sediment and tidal waters, and determining the mechanisms and efficiencies of $\mathrm{MeHg}$ transfer in relevant aquatic food webs originating from the dominant primary producers. 


\section{Introduction}

The total $\mathrm{Hg}(\mathrm{THg})$ levels in San Francisco Bay sediments range from 0.04 to $1.08 \mu \mathrm{g} \mathrm{g}^{-1}$ dry weight. Due to a history of placer gold and mercury mining, the bay's watershed contains high levels of THg. Furthermore, one of the world's largest $\mathrm{Hg}$ mines operated in the South Bay for many years. This has resulted in total sedimentary $\mathrm{THg}$ levels at or higher than those in sediments relative to other aquatic ecosystems perceived to present an $\mathrm{Hg}$ environmental toxicity risk (e.g., the Everglades). These high levels of total mercury ( $\mathrm{THg}$ ) in the bay and adjacent watershed will not be easily changed. Although environmental regulations are based on THg levels, methylmercury ( $\mathrm{MeHg}$ ) is the most toxic $\mathrm{Hg}$ species and the cause of the greatest concern. Levels of $\mathrm{MeHg}$ might be effectively managed if a mechanistic understanding can be developed of its formation, bioaccumulation into biota, and biomagnification up aquatic food webs.

Although $\mathrm{MeHg}$ generally comprises less than 1 percent of the $\mathrm{THg}$ in most soils and sediments, $\mathrm{MeHg}$ generally comprises approximately 99 percent of the total $\mathrm{Hg}$ in biomass. $\mathrm{MeHg}$ biomagnifies up food chains and is neurotoxic. $\mathrm{MeHg}$ is the form of $\mathrm{Hg}$ that is of greatest concern with respect to human health and risk assessment. Knowledge of the environmental factors that control the standing pool size of $\mathrm{MeHg}$, and its introduction into and magnification up food chains is needed for assessing the potential impacts of MeHg in the San Francisco Bay system. This is particularly true for the environmental risk posed by the construction of intertidal wetlands, systems that are known to produce $\mathrm{MeHg}$.

Microorganisms are the agents responsible for both the methylation of $\mathrm{Hg}^{2+}$ to $\mathrm{MeHg}$ and the demethylation of $\mathrm{MeHg}$ to $\mathrm{Hg}^{2+}$. It is unclear why bacteria catalyze these reactions. Detoxification has been suggested but it is unclear which species of $\mathrm{Hg}$ are more toxic to bacteria. Electron transport for metabolic energy production is another potential, but unproven, motivation. Under reducing conditions, anaerobic bacteria (especially some sulfate-reducing bacteria) oxidize sediment organic matter and transfer the resulting electrons through their cytochrome systems to available electron acceptors. When preferred terminal respiratory electron acceptors (e.g., sulfate) are limiting, some anaerobic bacteria will use whatever electron acceptor is available to them (perhaps $\mathrm{Hg}^{2+}+\mathrm{e}^{-} \rightarrow \mathrm{MeHg}$ ). Mercury methylation requires the presence of appropriate bacteria (e.g., some sulfate-reducing bacteria), a bioavailable and reactive form of mercury, and a carbon and energy source for respiration. Temporally/spatially fluctuating level of the preferred terminal electron acceptor (e.g., sulfate) appears to stimulate $\mathrm{MeHg}$ production. In contrast, many genera of aerobic microorganisms can demethylate $\mathrm{MeHg}$ back to $\mathrm{Hg}^{2+}$. This can be a fortuitous process but some microorganisms may be able to benefit from the carbon and energy produced in this reaction. The standing pool size of $\mathrm{MeHg}$ is the difference between the rates of the competing methylation and demethylation reactions. The standing $\mathrm{MeHg}$ pool is believed to be very dynamic, but the factors that drive the competing methylation and demethylation reactions are not currently known. Moreover, the potential for the standing pool of $\mathrm{MeHg}$

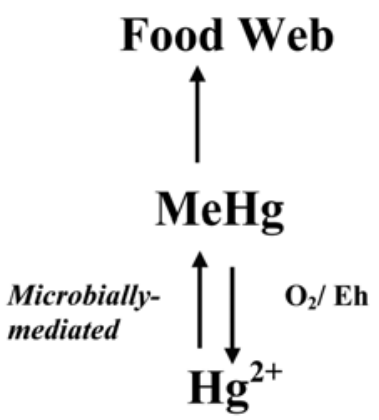


to be introduced into the food web is a function of the size of the MeHg pool and its availability to biota.

Spartina foliosa and Salicornia virginica are the most abundant plant genera at the HAAF site and will be the dominant genera in the reconstructed wetland. These wetland plants are typical for the low and high marsh parts, respectively. These aquatic macrophytes trap sediment particles that sustain the wetland, provide habitat for wetland fauna, and are the main sources of organic carbon and energy to the wetland system. Marshes usually serve as net sources of $\mathrm{MeHg}$ in aquatic systems. With respect to mercury geochemistry, these dominant plants will trap mercury-containing sediments in the marsh and affect the microbial metabolism in their root zones. Accumulation of $\mathrm{MeHg}$ directly into plant biomass is probably a major route of $\mathrm{MeHg}$ accommodation into the aquatic food web. However, this process is poorly understood, as is the fate of $\mathrm{MeHg}$ in plant detritus.

Marsh plants may accumulate $\mathrm{Hg}$ and $\mathrm{MeHg}$ in their tissues, and as such serve as sources for biomagnification of these compounds for higher trophic levels. Additionally, they directly affect the species composition, and types and levels of metabolic activities of microbial communities in their root zones. Plants release a variety of organic nutrients that selectively enhance a beneficial microbial community around their roots. During the photoperiod some plants actively pump oxygen from their roots into the sediment. These plant activities create a metabolically active, diurnally dynamic habitat in surface sediments. In addition, water inundations driven by tidal cycles profoundly affect physicochemical parameters such as oxygen diffusion into sediment and advective transport (e.g., sulfate, $\mathrm{Hg}^{2+}, \mathrm{MeHg}, \mathrm{Fe}^{2+}$, etc.).

\section{Purpose}

A large part of the research addressed in this feasibility study (Tasks II and VII in the Scope of Work for FY2003) was designed to address consensus technical questions formulated at the CALFED Stakeholders Workshop on Mercury in San Francisco Bay, held 8-9 October 2002 at Moss Landing Marine Laboratories. These included:

a. What are the present levels of MeHg in SF Bay wetlands with respect to biota, sub-habitats, and location within the bay?

b. What are the rates of $\mathrm{MeHg}$ production?

c. What factors control MeHg production? Can these be managed?

d. Are some wetlands larger mercury exporters than others?

e. Can we model/predict the effects of wetland restoration on $\mathrm{MeHg}$ production and export?

This exploratory field study was initiated in 2003 to specifically: 
a. Measure total $\mathrm{Hg}$ and $\mathrm{MeHg}$ levels in sediments from low marsh (mud), middle marsh (Spartina foliosa), high marsh (Salicornia virginica), and epipelonvegetated mud from different locations in and adjacent to HAAF.

b. Concurrently measure rates of $\mathrm{Hg}^{2+}$ methylation and $\mathrm{MeHg}$ demethylation potential in sediments from low marsh (mud), middle marsh (Spartina foliosa), high marsh (Salicornia virginica), and epipelon-vegetated mud from different locations in and adjacent to HAAF.

c. Explore the following factors potentially influencing methylation and demethylation rates:

1. Illumination.

2. Plant species.

3. Redox potential and $\mathrm{pH}$.

4. Composition of the microbial community.

\section{Study Site}

The Hamilton Army Airfield on San Pablo Bay is part of the San Francisco Baylands. It is located in the North Bay Subregion. The Baylands consist of the shallow-water habitats around the San Francisco Bay between the maximum and minimum elevations of the tides. The Baylands ecosystem includes the areas of maximium and minimum tidal fluctuations, adjacent habitats, and their associated plants and animals. The boundaries of the ecosystem vary with the bayward and landward movements of fish and wildlife that depend upon the Baylands for survival. Many habitats of the Baylands are wetlands. Habitat goals selected for the restored HAAF include tidal marshes, with natural transitions into upland areas with seasonal wetlands. The restored HAAF area is expected to increase the habitat of the regionally rare clapper rail, because it will contain a large tidal wetland and is remote from predator outposts and corridors (San Francisco Bay Area Wetlands Ecosystem Goals Project 1999).

Samples were collected and incubated in two tidal marshes, a marsh bordering the HAAF and a reference marsh. The test site was situated at the HAAF Bay Edge (SM-10; $38^{\circ} 03.116 \mathrm{~N}, 122^{\circ} 29.550 \mathrm{~W}$; Figure 3-1) and the reference site in the China Camp State Park wetland (R-44; $38^{\circ} 04.379 \mathrm{~N}, 122^{\circ}$ $28.758 \mathrm{~W})$. Where possible, locations within each site were chosen to represent the low marsh (mud), middle marsh (Spartina foliosa), and high marsh (Salicornia virginica). All samples were collected in the period 9-11 June 2003. 


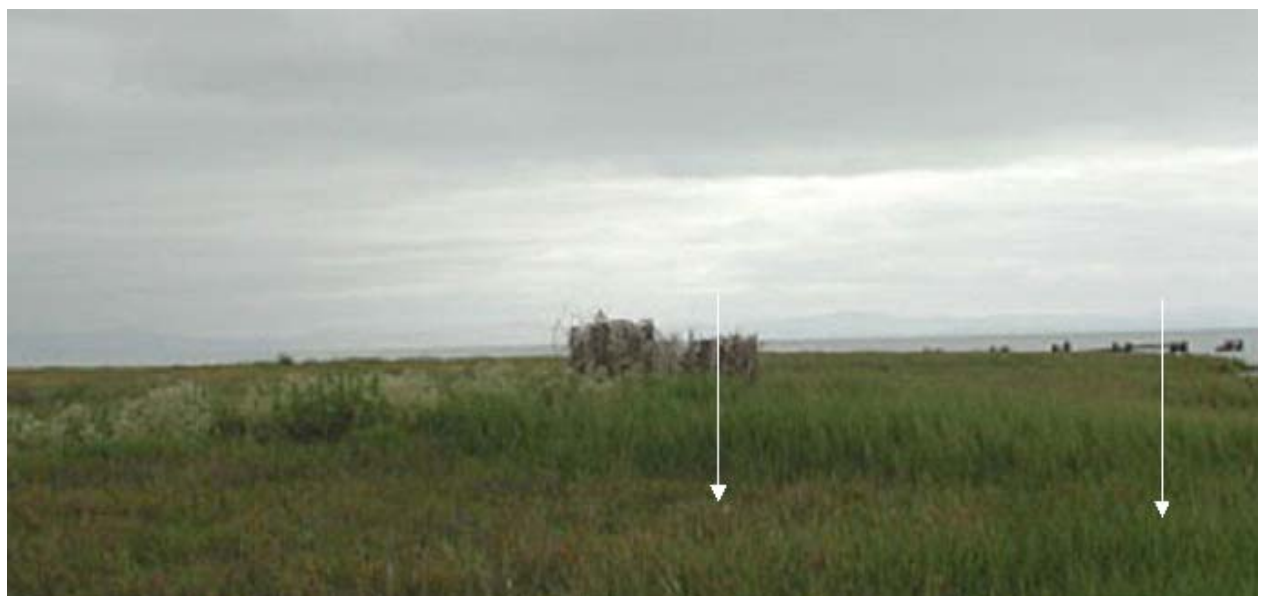

Figure 3-1. Study site at the HAAF Wetlands Restoration Site. Locations where measurements were performed are marked by arrows

\section{Approach}

\section{Sediment sampling}

A special sediment corer was constructed by the Engineer Research and Development Center's (ERDC) shops (Figure 3-2). Undisturbed 9.5-cm-diam sediment cores were collected and used for the onsite incubations to derive methylation and demethylation rate measurements. This corer was placed over an intact plant, twisted into the sediment to a depth of approximately $20 \mathrm{~cm}$, and used to extract the entire plant, roots, and adjacent sediment. A solution of ${ }^{199} \mathrm{Hg}^{2+}$ and $\mathrm{CH}_{3}{ }^{200} \mathrm{Hg}^{+}$was injected through pre-drilled ports in the acrylic tube core liner at three different depths $(2.5,5$ and $9-10 \mathrm{~cm})$ of each core. Epipelon, the micro-algal mat complex growing in patches on the sediment surface, was collected by scraping off the top 1-cm layer of mat, transferring the material into plastic centrifuge tubes, adding water from the same site, and amendment with isotopes. After injection of isotopes, all cores and tubes were set back into their original location and incubated in place for $5 \mathrm{hr}$. Control tubes with epipelon were placed within the undisturbed vegetation, in which the tubes were exposed to the typical light climate within a $S$. foliosa vegetation. This procedure is described below.

Smaller diameter PVC cores $(5 \mathrm{~cm})$ were collected immediately adjacent to the large diameter cores. Sediment samples from 2-, 5-, and 10-cm depths were analyzed for polar membrane lipid fatty acid (PLFA) analyses. PLFA analyses provide a measure of sedimentary microbial community biomass and taxonomic composition. This procedure is described below. 


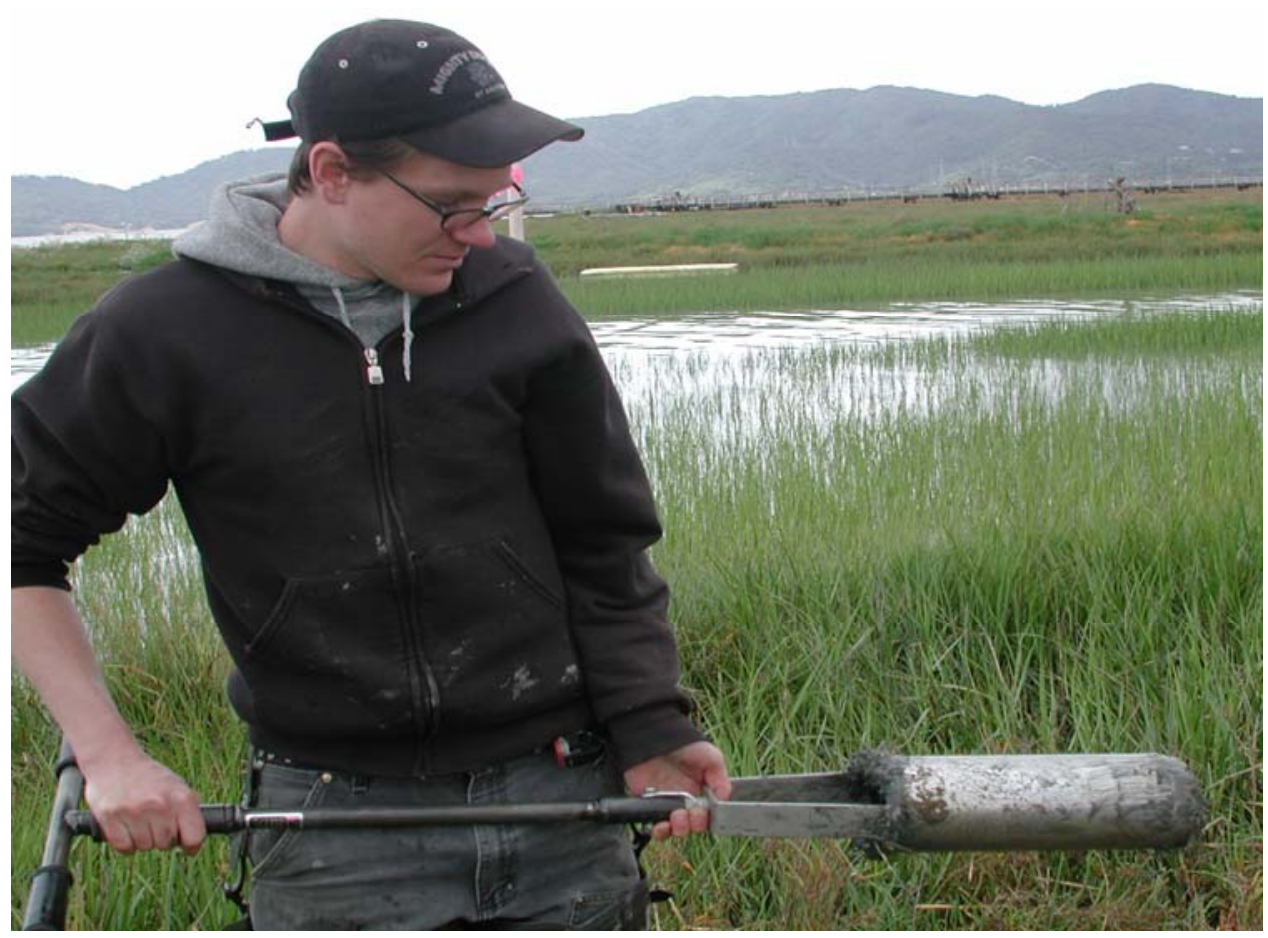

Figure 3-2. Sediment corer constructed to collect 9.5-cm-diam vegetated sediment cores

\section{Light-dark core manipulations}

Two approaches were planned to determine the effects of the dominant marsh plants on microorganisms that mediate $\mathrm{Hg}^{2+}$ methylation and $\mathrm{MeHg}$ demethylation. Relevant parameters were measured in the plant root zones and compared to those parameters measured in nonvegetated areas. However, in practice it was very difficult to find sediment where plant roots were not present. The second approach was to cover for $5 \mathrm{hr}$ selected vegetated and nonvegetated sediment cores with black plastic bags, and compare relevant root zone measures in illuminated and darkened sediment cores (Figures 3-3 and 3-4).

\section{Redox potential and $\mathrm{pH}$ measurements}

The redox potential $\left(\mathrm{E}_{\mathrm{h}}\right)$ is a relative measure of oxidizing/reducing conditions in a soil. $\mathrm{E}_{\mathrm{h}}$ depends on both the presence of electron acceptors (oxygen and other oxidizing agents) and $\mathrm{pH}$. In a well-drained soil the $\mathrm{E}_{\mathrm{h}}$ is in the 400 - to $700-\mathrm{mV}$ range. In flooded conditions $\mathrm{E}_{\mathrm{h}}$ values as low as $-300 \mathrm{mV}$ can be found. Microbial transformation rates in soils are strongly influenced by $E_{h}$. $E_{h}$ 's in root zones of plants are influenced through oxidation due to oxygen loss from the plants' photosynthesis in the light, and through reduction due to the plants' respiration in darkness. Sediment redox and $\mathrm{pH}$ were measured at the end of the incubation period using an Orion $\mathrm{pH} / \mathrm{mV}$ meter (Model 250A ) adapted with a self-manufactured platinum-tip (pt) redox electrode (Boehn 1971; Faulkner et al. 1989), or a pH electrode (Orion model 91-05). Electrodes were calibrated with 
quinhydrone solution or $\mathrm{pH}$ buffers (Orion, Beverly, MA), respectively, prior to use. Electrodes were inserted into the sediment with the tips contacting sediment at 2.5-, 5-, and 10-cm depths at the beginning of the incubation period. $\mathrm{E}_{\mathrm{h}}$ was measured at all sites (two test and one reference) at three sediment depths, 0.5, 5, and $10 \mathrm{~cm}$, as close as possible to three of the incubated cores. At only one site, i.e. the China Camp reference site, $\mathrm{E}_{\mathrm{h}}$ was measured also inside the darkened and non-darkened cores. $\mathrm{E}_{\mathrm{h}}$ values were calculated from measured $\mathrm{mV}$ readings of Ptelectrodes and corrected for the potential of the reference $\mathrm{AgCl}$ electrode (222.34 $\mathrm{mV}) . \mathrm{pH}$ was measured also at all sites, but only in the surface sediment.
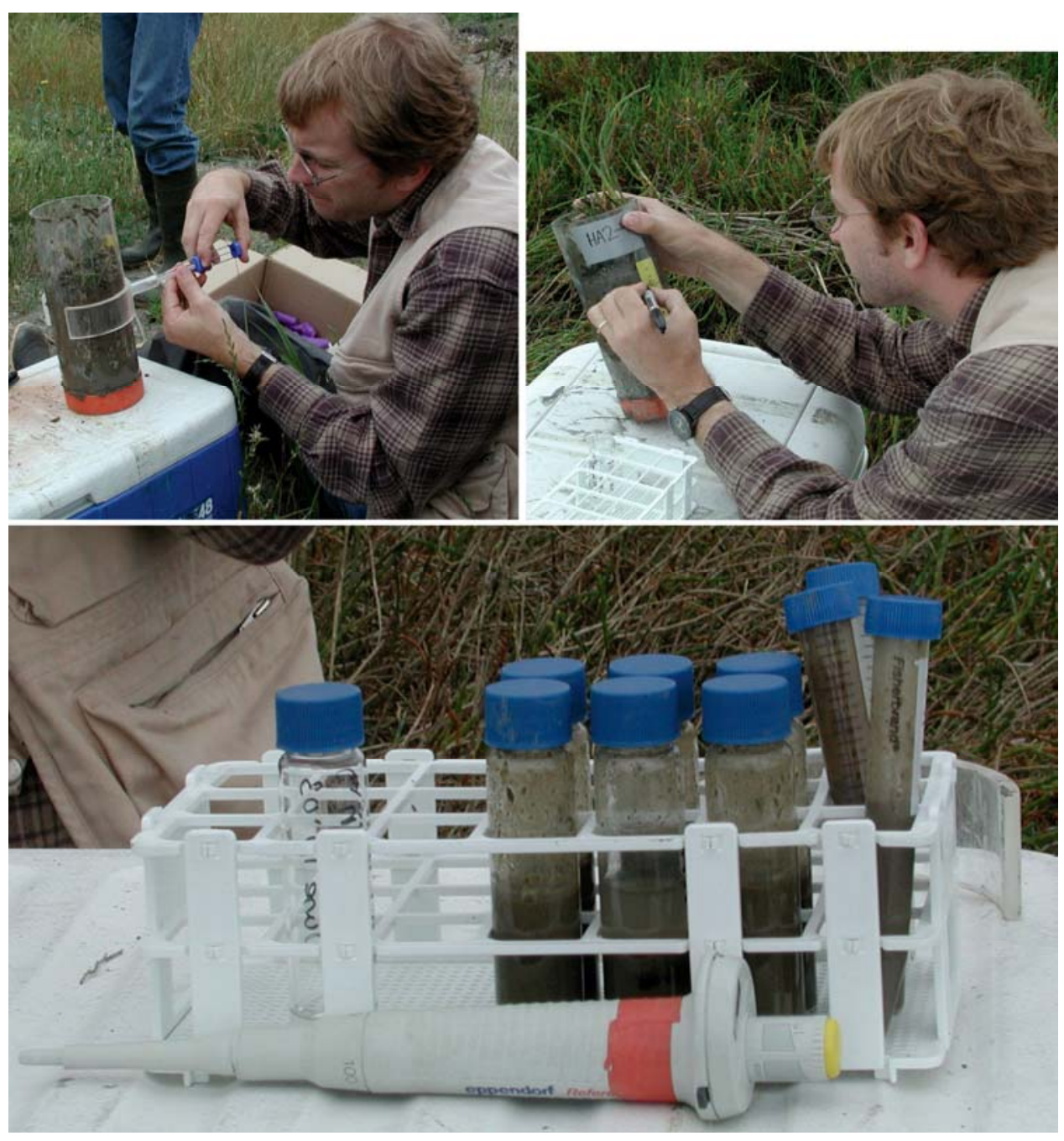

Figure 3-3. Administering isotopes to sediment cores and epipelon suspensions 

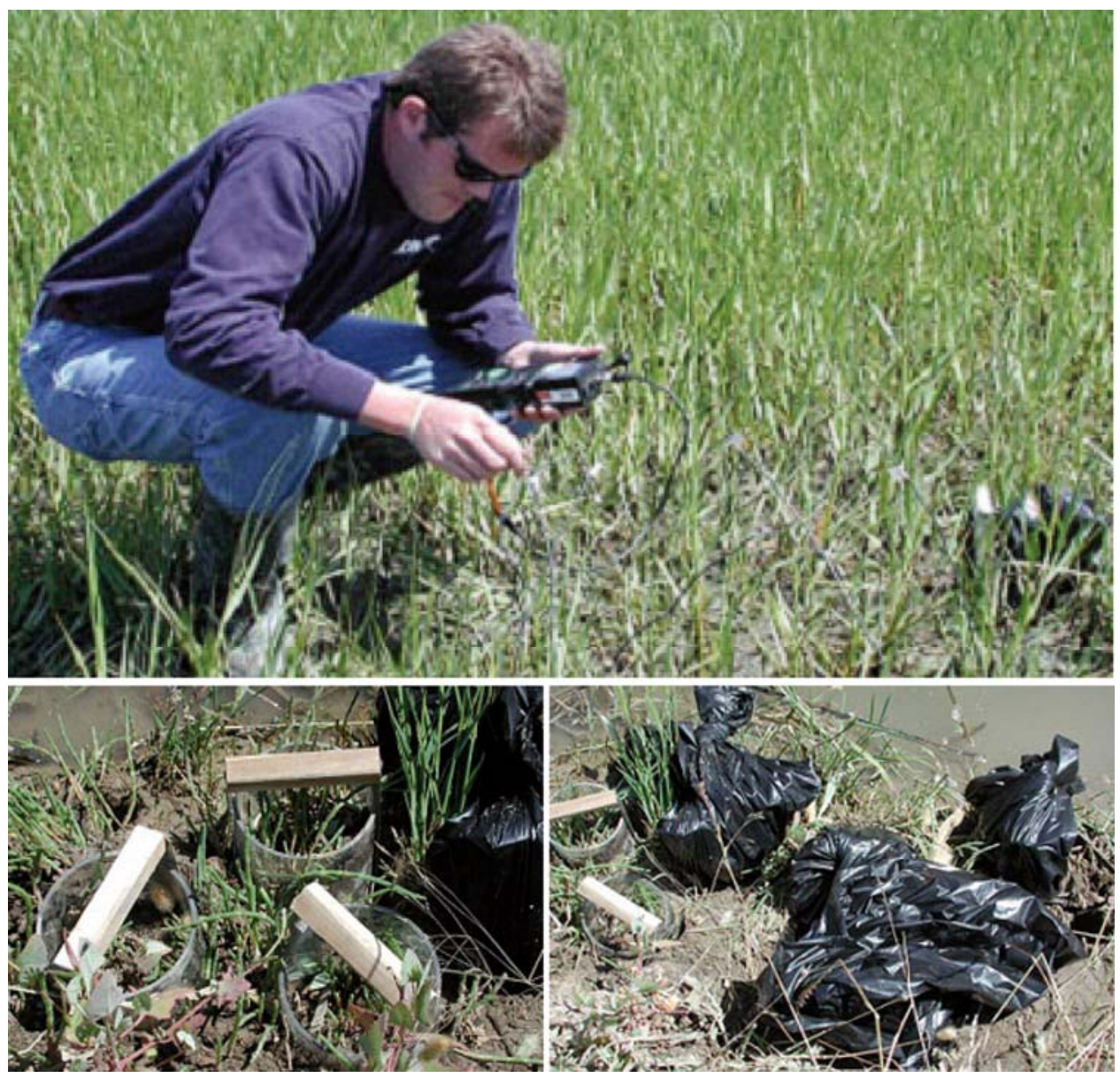

Figure 3-4. Incubation of vegetated cores in light and in darkness (upper); and onsite determinations of redox potential and $\mathrm{pH}$ (lower)

\section{Polar lipid fatty acid analyses}

Polar lipid fatty acid analysis has been detailed elsewhere (Fredrickson et al. 1986). Briefly, two- (wet weight) sediment samples were collected from the frozen cores at depths of 2, 5, and $10 \mathrm{~cm}$. These samples were extracted for $3 \mathrm{hr}$ at room temperature in $6 \mathrm{ml}$ of a mixture of dichloromethane:methanol:water (1:2:0.8, v:v:v). Amino-propyl solid phase extraction columns (Supelco, Bellefonte, PA) were used to separate the total lipid into neutral, glycol, and polar lipid fractions. Phospholipid fatty acid methyl esters (from the polar lipid fraction) were prepared for gas chromatography/mass spectrometry (GC/MS) by mild alkaline methanolic transesterification. The resulting phospholipid fatty acid methyl esters were dissolved in hexane containing methyl nonadecanoate $\left(50 \mathrm{pmol} \mu \mathrm{L}^{-1}\right)$ as an internal standard and analyzed using a gas chromatograph equipped with a $50-\mathrm{m} \times 0.25-\mathrm{mm}$ (ID) DB-1 capillary column $(0.1 \mu \mathrm{m}$ film thickness, J\&W Scientific, Folsom, CA) and a flame ionization detector. Peak identities were confirmed using a gas chromatograph-mass selective detector (Hewlett Packard GC6890-5973 MSD) with electron impact ionization at 70eV. Areas under the peaks were converted to concentrations, summed, and then normalized to the gram weight extracted for biomass determinations. For community 
comparisons, the percent contribution of each peak was calculated and then normalized using an arcsine square root transformation.

\section{Stable Hg isotopic tracer studies}

${ }^{199} \mathrm{HgCl}_{2}$ was used for the methylation assay. ${ }^{199} \mathrm{HgO}$ (Oak Ridge National Laboratories) was converted into ${ }^{199} \mathrm{HgCl}_{2}$ by dissolving $0.690 \mathrm{mg}$ of ${ }^{199} \mathrm{Hg}$ enriched (91.95 percent purity) $\mathrm{HgO}$ in $1 \mathrm{~mL}$ of hydrochloric acid $(10 \mathrm{mM})$, resulting in a solution with a concentration of $0.588 \mathrm{mg} / \mathrm{mL}^{199} \mathrm{Hg} . \mathrm{CH}_{3}{ }^{200} \mathrm{HgCl}$ was prepared for the demethylation assay. ${ }^{200} \mathrm{Hg}$ enriched (96.41 percent purity) $\mathrm{HgO}$ (Oak Ridge National Laboratories) was synthesized using the methylcobalamin method as described in Hintelmann et al. (2000). The final isotopic solution had a concentration of $345 \mathrm{ng} / \mathrm{mL}^{200} \mathrm{Hg}$ (as Me ${ }^{200} \mathrm{Hg}$ ). $250 \mu \mathrm{L}$ of the ${ }^{199} \mathrm{Hg}$ solution was mixed with $266 \mu \mathrm{L}$ of $\mathrm{Me}^{200} \mathrm{Hg}$ solution and diluted to $10 \mathrm{~mL}$.

The solution $(100 \mu \mathrm{L})$ of ${ }^{199} \mathrm{Hg}^{2+}$ and $\mathrm{CH}_{3}{ }^{200} \mathrm{Hg}^{+}$was injected through predrilled ports in the acrylic tube into three different layers $(2,5$, and $9-10 \mathrm{~cm})$ of each core. A total of $1,470 \mathrm{ng}$ of ${ }^{199} \mathrm{Hg}$ (II) and $0.918 \mathrm{ng}$ of $\mathrm{Me}^{200} \mathrm{Hg}$ was injected into each layer. One set of samples was placed into a black plastic bag to assess the effects of plant photosynthesis. After injection of isotopes, all cores were set back into their original location and incubated in place for $5 \mathrm{hr}$. Incubation was terminated by quick-freezing of cores, including plants, with dry ice in the field. Samples remained frozen until analysis in the lab.

\section{Frozen core sample handling}

The above-ground plant material was cut off from the sediment core and weighed. The frozen cores were extruded from the plastic tube and cut into $1 / 2$-in. slices using a diamond-tipped cutting blade. The area injected with mercury isotopes was further isolated by cutting out a $1 / 2$-in. strip from the center area around the injection point, resulting in a $1 / 2-x^{1 / 2}-\mathrm{x}$ 4-in. sediment core containing the injected solution of isotopes. This sub-core was further homogenized and subsamples were taken for the various measurements. Root material was obtained by washing a sub-sample of the isolated core over a fine-meshed sieve to remove clay and silt particles from the roots. The relative amounts of sediments and root material (wet weight) were determined at this stage. Wet sediment was dried at $50{ }^{\circ} \mathrm{C}$ overnight or until weight consistency was obtained to determine the dry/wet weight ratio (percent solids). The loss on ignition (LOI) was determined by ashing the dried sample at $500{ }^{\circ} \mathrm{C}$ for $4 \mathrm{hr}$ or until weight consistency was obtained.

\section{Total Hg determination}

About $0.2 \mathrm{~g}$ of sample was weighed into $30-\mathrm{mL}$ acid-washed glass vials. Then $12.2 \mathrm{ng}$ of ${ }^{201} \mathrm{HgCl}_{2}$ was added as an internal standard. After addition of $5 \mathrm{~mL}$ of concentrated $\mathrm{H}_{2} \mathrm{SO}_{4} / \mathrm{HNO}_{3}$, the mixture was left to react for $1 \mathrm{hr}$ at room temperature. Digestion was finished by heating vials in an $\mathrm{Al}$ block at $120^{\circ} \mathrm{C}$ on 
a hot plate for $3 \mathrm{hr}$ or until formation of brown nitrous gases had ceased. The digest was diluted with Milli-Q water to the mark.

The concentration of $\mathrm{Hg}$ isotopes in the digest was quantified using continuous-flow cold-vapor generation with ICP/MS detection (Finnigan MAT, Model Element 2). The acidified sample was continuously mixed with a solution of stannous chloride by means of a peristaltic pump. The formed mercury vapor was separated from the liquid in a gas-liquid separator (Model L1-2) and the elemental mercury swept into the plasma of the ICP/MS. The following isotopes of $\mathrm{Hg}$ were measured: ${ }^{199} \mathrm{Hg}$ (added isotope for the methylation assay), ${ }^{200} \mathrm{Hg}$ (added isotope for the demethylation assay), ${ }^{201} \mathrm{Hg}$ (internal standard) and ${ }^{202} \mathrm{Hg}$ (to calculate ambient total $\mathrm{Hg}$ ). Concentrations of individual isotopes were calculated using an Excel spreadsheet, employing matrix algebra, as described in Hintelmann and Ogrinc (2003).

\section{MeHg determination}

A method modified from Hintelmann and Evans (1997) was used. Approximately $0.2 \mathrm{~g}$ of sample was weighed into $30-\mathrm{mL}$ Teflon vials. $\mathrm{CH}_{3}{ }^{201} \mathrm{HgCl}(55 \mathrm{~g})$ was added as an internal standard. Then $200 \mu \mathrm{L}$ of $\mathrm{H}_{2} \mathrm{SO}_{4}(9 \mathrm{M})$ and $500 \mu \mathrm{L}$ of $\mathrm{KCl}$ (20 percent) were added, and the vessel was placed into a heating block at $140{ }^{\circ} \mathrm{C}$. MeHg was distilled from the sample under a supporting nitrogen stream $\left(80 \mathrm{~mL} \mathrm{~min}{ }^{-1}\right)$. Distillation time was approximately 60 to $90 \mathrm{~min}$ per sample.

A reaction vessel was filled with $100 \mathrm{ml}$ Milli-Q water, and the distillate was added for measurement of MeHg. Then $0.2 \mathrm{ml}$ of acetate buffer $(2 \mathrm{M})$ was added to adjust the $\mathrm{pH}$ to 4.9 . Sodium tetraethylborate $(100 \mu \mathrm{L}, 1$ percent $\mathrm{w} / \mathrm{v})$ was added and the solution was left sitting at room temperature for $20 \mathrm{~min}$ for the tetraethylborate to react. Tenax adsorber traps were connected to the reaction vessel and the generated $\mathrm{MeHg}$ was purged from the solution using nitrogen (200 $\mathrm{mL} \min ^{-1}$ ) and collected on the Tenax trap. Finally, mercury species were thermally desorbed from the trap $\left(250^{\circ} \mathrm{C}\right)$, separated by gas chromatography, and quantified by ICP/MS (Micromass Platform). The following isotopes of $\mathrm{Hg}$ were measured: ${ }^{199} \mathrm{Hg}$ (methylated $\mathrm{Hg}$ ) ${ }^{200} \mathrm{Hg}$ (MeHg demethylation assay),

${ }^{201} \mathrm{Hg}$ (internal standard) and ${ }^{202} \mathrm{Hg}$ (to calculate ambient $\mathrm{MeHg}$ ). Peak areas were used for quantification, and concentrations of individual isotopes were calculated using an Excel spreadsheet, employing matrix algebra, as described in Hintelmann and Ogrinc (2003).

\section{Hg analysis QA/QC}

For each batch of samples, the following set of QA/QC samples was measured: three reagent blanks $(\mathrm{THg})$ or bubbler blanks $(\mathrm{MeHg})$ and a certified reference material (IAEA 356 marine sediment and MESS-3 marine estuary sediment for sediment analysis and NIST 1515 apple leaves for plant analysis). Individual distillation yields were determined using the added internal ${ }^{201} \mathrm{Hg}$ isotope standard. 


\section{Results and Discussion}

\section{Background information on tidal marsh structure and function}

A central question arising from the biogeochemical study of mercury is, "How do concentrations of parts per trillion of mercury in water yield concentrations of parts per million in fish?" (Gilmour and Henry 1991; Morel et al. 1998). To address this question, it is important to understand the behavior of mercury in coastal systems in the context of the structure and function of that system. To this end, the following synopsis is provided of selected relevant features of tidal marshes in San Francisco Bay.

Importance of hydrology and elevation. Coastal wetlands depend upon tides and rainfall for their moisture. Rainfall is usually restricted to the cool season, and freshwater runoff is limited largely to the wet periods. Hence, during most of the warm growing season, the salt marsh vegetation receives water only from the sea. Any alteration of tidal circulation, therefore, has a major effect on the entire wetland ecosystem, both by changing the frequency of wetting and by altering salinities.

Intertidal wetlands exist as a continuum of habitats within coastal and estuarine systems (Callaway 2001). At HAAF, the experimental site, and China Camp, the reference site, this range of habitats includes subtidal areas, intertidal flats, tidal creeks and channels, salt marsh, and wetland-upland ecotones. In most natural marshes, sedimentation rates are in equilibrium with relative sea-level rise, resulting in a stable elevation of the marsh plain. The marsh plain usually stabilizes at elevations between Mean High Water (MHW) and Mean Higher High Water (MHHW; Allen 1990, 1994; Pethick 1992). The relative elevation of the marsh surface is affected by many factors. In addition to the feedback between elevation and sediment inputs (both tidal and storm inputs), other factors are also linked to elevation via a feedback mechanism. These include biomass production (above- and belowground) and decomposition of the vegetation. Eustatic sea-level rise, subsidence, and tectonic activity affect the relative elevation of the marsh, but without any feedback mechanism.

Tidal marsh vegetation zones. Three general zones of vegetation typically characterize the tidal salt marsh, each of which is related to tidal elevation and distance from shore. Low tidal salt marsh occurs between the lowest margin of the marsh and MHW. Middle tidal marsh occurs between MHW and MHHW. High tidal marsh occurs between MHHW and the highest margin of the marsh. Tidal marshes have a variety of important components including tidal channels. Large tidal channels and their smaller tributaries form drainage networks that distribute tidal waters throughout the marsh. Channel density (i.e., the amount of channel habitat per area of marsh plain) is directly related to tidal prism, the volume of water that flows into and out of the marsh. Channel density may also be related to salinity; salt marshes generally have denser networks of tidal channels than do brackish marshes (Grossinger 1995).

Spartina foliosa (Pacific cordgrass) and Salicornia virginica (common pickleweed) are the dominant higher plant species in the San Francisco Bay tidal 
salt marshes. Pacific cordgrass is usually the primary colonizer on broad tidal mudflats that fringe tidal marsh plains, and it occurs in virtually pure stands in the low marsh between Mean Tidal Level (MTL) and MHW. Midway within this tidal range it intermixes with Salicornia virginica (common pickleweed), especially in the depressions in the marsh plain. In the middle tidal marsh, at elevations near and above MHW, Pacific cordgrass yields to common pickleweed. The latter species is a perennial succulent that dominates around the bay. In the high tidal marsh, between MHW and the maximum extent of the tides, common pickleweed occurs in association with peripheral halophytes such as Distichlis spicata (saltgrass) and Atriplex triangularis (fathen). All three zones described occur at both HAAF and China Camp.

Primary production, decomposition, and importance for the food web. Because MeHg is efficiently biomagnified up many aquatic food webs, it is important to study mercury biogeochemistry against the backdrop of wetland trophic structure. Marshes generally have a net primary production rate that is higher than that of any other ecosystem type. In an overview of primary production and biomass estimates for the world, salt marshes are listed as harboring on average a mean biomass of $6.8 \mathrm{~kg}^{-1}$ carbon $\mathrm{m}^{-2}$, and having a net primary production rate of $1,125 \mathrm{~g}$ carbon $\mathrm{m}^{-2} \mathrm{yr}^{-1}$ (Schlesinger 1991). Primary production values published for California salt marsh vegetation vary greatly, ranging between 70 and 2,858 $\mathrm{g} \mathrm{C} \mathrm{m}^{-2} \mathrm{yr}^{-1}$ (Table 3-1) depending on the elevation within the marsh, influence of freshwater inputs, climate (latitude) and species composition. Based on the latter production rates, a maximum aboveground biomass production of $715 \mathrm{~g} \mathrm{DW}$ per year was expected $\left(2,858 \mathrm{~g} \mathrm{C} \mathrm{m}^{-2} \mathrm{yr}^{-1} \mathrm{x} 0.25\right)$ in natural marshes, and of $996 \mathrm{~g} \mathrm{DW} \mathrm{m}^{-2}$ in multi-species, planted, marshes (Callaway et al. 2003). Inferences as to rates of primary production based on casual observations of standing biomass can be misleading, because of the differences in growth and senescence strategies among vascular macrophyte species, and between algae and vascular macrophytes. For instance, in Mugu Lagoon, CA, primary production of vascular macrophytes in the low marsh was lower than that of epipelic algal mats, whereas primary production of vascular macrophytes in the high marsh was lower than that of submerged macrophytes, but higher than that of phytoplankton (Onuf 1987).

Part of the primary production is utilized by macroconsumers directly via herbivory of live plant tissues or indirectly via the detritus pool. The importance of the various primary producers of the marsh for the consumers is strongly influenced by the tissue quality of live and dead plant material, situation within the marsh landscape relative to the sea, creeks and upland area, and the physicaltemporal separation between the primary producers and consumers (Table 3-2; Onuf 1987; Winfield 1980). Strong food web linkages were found between macrophytes of the low and high marsh, microalgae of marsh pools, macroalgae from the mid-marsh, and invertebrates, fish, and clapper rails in San Dieguito Lagoon and Tiyuana Bay in southern California, using a multiple stable isotope ratio approach (Table 3-3; Kwak and Zedler 1997). At this time a limited number of food web studies have been conducted, but none of these takes biomagnification of $\mathrm{MeHg}$ into consideration. 


\begin{tabular}{|c|c|c|c|c|}
\hline \multicolumn{5}{|c|}{$\begin{array}{l}\text { Table 3-1 } \\
\text { Estimated Rates of Primary Production in California Marshes }\end{array}$} \\
\hline Primary Producer & $\begin{array}{l}\text { Net Primary } \\
\text { Production, } \mathrm{g} \mathrm{C} \mathrm{m}^{-2} \mathrm{y}^{-1}\end{array}$ & $\begin{array}{l}\text { Net Primary Production, } \\
\text { g DW } \mathrm{m}^{-2} \mathrm{y}^{-1}\end{array}$ & $\begin{array}{l}\text { Maximum Standing } \\
\text { Crop, g DW } \text { m }^{-2}\end{array}$ & Reference \\
\hline \multicolumn{5}{|l|}{ Marsh vegetation $^{1}$} \\
\hline Low marsh, 6-species & & & 995.6 & Callaway et al. 2003 \\
\hline Low marsh, 1-species & & & 572.1 & Callaway et al. 2003 \\
\hline \multicolumn{5}{|l|}{ Marsh vegetation $^{2}$} \\
\hline Low marsh & $916-935$ & & & Zedler et al. 1980 \\
\hline High marsh & $412-1046$ & & & Zedler et al. 1980 \\
\hline Low marsh3 & 2,858 & & & Zedler et al. 1980 \\
\hline High marsh3 & 1,202 & & & Zedler et al. 1980 \\
\hline Low marsh & $70^{3}$ & 290 & & Onuf 1987 \\
\hline High marsh & $180^{3}$ & 730 & & Onuf 1987 \\
\hline S. virginica & & & $200-800$ & Onuf 1987 \\
\hline Epipelic algae & 130 & & & Onuf 1987 \\
\hline Submerged macrophytes & 1300 & & & Onuf 1987 \\
\hline Phytoplankton & 50 & & & Onuf 1987 \\
\hline \multicolumn{5}{|c|}{$\begin{array}{l}{ }^{1} \text { Planted; aboveground parts only. } \\
{ }^{2} \text { Predominated by Salicornia virginica; aboveground parts only. } \\
{ }^{3} \text { With freshwater input. } \\
{ }^{4} 1 \mathrm{~g} \mathrm{C} \sim 0.25 \mathrm{~g} \mathrm{DW} \text {. }\end{array}$} \\
\hline
\end{tabular}

\begin{tabular}{|c|c|c|c|c|}
\hline \multicolumn{5}{|c|}{$\begin{array}{l}\text { Table 3-2 } \\
\text { Characteristics Influencing the Utilization Value of a Source of } \\
\text { Primary Production by Macroconsumers within a California Coastal } \\
\text { System (Mugu Lagoon; after Onuf (1987)) }\end{array}$} \\
\hline Characteristic & Phytoplankton & Epipelon & $\begin{array}{l}\text { Submerged } \\
\text { Macrophytes }\end{array}$ & \begin{tabular}{|l} 
Emergent \\
Macrophytes
\end{tabular} \\
\hline Live tissue nutritional quality & High & High & Moderate & Low \\
\hline Leaching of live plant & High & Moderate & Moderate & Low \\
\hline Leaching of dead plant & Very high & Very high & Moderate & Moderate \\
\hline Export to coastal water & Moderate & Moderate & High & High \\
\hline Export to upland & None & Slight & Slight & Moderate \\
\hline $\begin{array}{l}\text { Physical/temporal } \\
\text { separation - Primary } \\
\text { producer/consumer }\end{array}$ & None & None & Small & Large \\
\hline
\end{tabular}




\begin{tabular}{|c|c|c|c|c|c|c|}
\hline \multicolumn{7}{|c|}{$\begin{array}{l}\text { Table 3-3 } \\
\text { Multiple Stable Isotope Ratios (pro mille) of Primary Producers and Consumers } \\
\text { Collected from Two California Coastal Wetlands }\end{array}$} \\
\hline Species & Marsh Habitat & $\delta^{13} \mathrm{C} \pm$ SD & $\delta^{13} \mathrm{C} \pm$ SD & $\delta^{13} \mathrm{C} \pm \mathrm{SD}$ & $\mathrm{THg} \pm \mathrm{SD}$ & $\mathrm{MeHg} \pm \mathrm{SD}$ \\
\hline \multicolumn{7}{|c|}{ Primary Producers } \\
\hline \multicolumn{7}{|l|}{ Macrophytes } \\
\hline Spartina foliosa & Low marsh & $-15.1 \pm 0.2$ & $10.3 \pm 0.3$ & $11.5 \pm 0.5$ & TBD & TBD \\
\hline Salicornia virginica & High marsh & $-26.7 \pm 0.2$ & $11.0 \pm 1.2$ & $12.3 \pm 2.2$ & TBD & TBD \\
\hline \multicolumn{7}{|l|}{ Microalgae } \\
\hline Microcystis sp. & Marsh pool & -17.7 & 5.1 & 9.5 & TBD & TBD \\
\hline \multicolumn{7}{|l|}{ Macroalgae } \\
\hline Rhizoclonium sp. & Mid marsh & -20.2 & 9.6 & 17.5 & TBD & TBD \\
\hline \multicolumn{7}{|c|}{ Consumers } \\
\hline \multicolumn{7}{|l|}{ Birds } \\
\hline L-F Clapper rail & Low marsh & $-18.4 \pm 0.2$ & $17.9 \pm 0.1$ & $14.6 \pm 1.2$ & TBD & TBD \\
\hline \multicolumn{7}{|l|}{ Fish } \\
\hline Arrow goby & Channel & $-18.4 \pm 0.2$ & $17.9 \pm 0.1$ & $14.6 \pm 1.2$ & TBD & TBD \\
\hline Striped mullet & Channel & $-16.1 \pm 0.2$ & $16.0 \pm 0.2$ & $7.4 \pm 0.2$ & TBD & TBD \\
\hline \multicolumn{7}{|l|}{ Invertebrates } \\
\hline Mytilus edulis & Channel & -18.0 & 10.0 & 13.7 & TBD & TBD \\
\hline Orchestia traskiana & Mid marsh & -21.5 & 11.5 & 14.1 & TBD & TBD \\
\hline
\end{tabular}

\section{Effects of macrophytes on their rhizospheres}

Besides influencing marsh elevation by trapping sediment (see above), marsh plants can change the chemistry in their rhizosphere through physiological processes. These plant-mediated changes can greatly affect the competing $\mathrm{Hg}$ methylation and demethylation competing reactions in wetland surface sediments.

Proton extrusion by roots may reduce rhizosphere $\mathrm{pH}$ (by more than 2 units from that in the bulk sediment). By their reducing and oxidizing activities, roots affect the redox potential in the sediment. Reduction in the rhizosphere is particularly important for the acquisition of iron or other metals when present in their lessmobile oxidized states in the sediment. On the other hand, roots in sediments can oxidize compounds in the rhizosphere, largely by the release of oxygen. This can reduce the solubility of potentially toxic ions such as mercury, aluminum, and sulfide. Roots often excrete exudates (e.g., organic acids) that mobilize sparingly soluble micronutrients, or stimulate the activity of rhizosphere microorganisms (after Lambers et al. 1998).

Field observations in salt marshes bordering San Pablo Bay indicated that the redox potential $\left(\mathrm{E}_{\mathrm{h}}\right)$ was below zero in all sediments (Table 3-4). In undisturbed compartments (i.e., outside the in situ incubated cores), $E_{h}$ fluctuated between -91 and $-202 \mathrm{mV}$ in nonvegetated sediments, between -114 and $-222 \mathrm{mV}$ in epipelonassociated sediments, between -104 and $-248 \mathrm{mV}$ in $S$. foliosa-vegetated 
sediments, and between -127 and $-217 \mathrm{mV}$ in $S$. virginica-vegetated sediments. In vegetated sediments fluctuations tended to be larger and showed lower negative extremes than in nonvegetated sediments. Vegetation clearly affected $E_{h}$ in the sediments of the incubated cores (Figure 3-5). $\mathrm{E}_{\mathrm{h}}$ tended to be less negative in illuminated vegetated cores than in darkened vegetated cores, particularly at 10-cm depth in the sediment. $\mathrm{E}_{\mathrm{h}}$ in nonvegetated cores fluctuated between -91 and $-202 \mathrm{mV}$ and did not exhibit this trend. The main difference between the $\mathrm{E}_{\mathrm{h}}$ profiles of vegetated and nonvegetated cores appeared to be that $E_{h}$ was more negative at the 2.5- and 5-cm depths, (in both light and dark conditions) in the presence than in the absence of vegetation. This suggests a relationship between anoxic decomposition of plant materials at these depths, possibly establishing $\mathrm{E}_{\mathrm{h}}$ conditions conducive for $\mathrm{MeHg}$ production (see section "Factors controlling $\mathrm{MeHg}$ production"). $\mathrm{pH}$ values in the surficial sediments of HAAF and China Camp (outside the incubated cores) ranged from 7.0 to 7.5 (Table 3-4). $\mathrm{pH}$ values decreased in incubated cores to 6.6-6.7. Conditions in the sediment with $\mathrm{pH} 6.6$ and $E_{h}$ ranging from -180 to $0 \mathrm{mV}$ or more positive would favor $\mathrm{Hg}$ speciation into $\mathrm{Hg}^{0}$, whereas those of $\mathrm{pH} 6.6$ and $\mathrm{E}_{\mathrm{h}}$ ranging from -180 to $-450 \mathrm{mV}$ would favor $\mathrm{Hg}$ speciation into $\mathrm{Hg}^{2+}$ (Figure 3-6).

\section{Current levels of THg and MeHg in San Francisco Bay wetlands}

Several studies indicate that wetlands may contain considerable stores of $\mathrm{MeHg}$ in both organic matter and pore water (Heyes 1996), and may serve as a source for the water body immediately adjacent to it (St. Louis et al. 1994, 1996). However, although the potential importance of wetlands as sources of $\mathrm{MeHg}$ has been realized, only recently have studies of the internal cycling of $\mathrm{Hg}$ and production of $\mathrm{MeHg}$ been initiated.

THg and MeHg in sediment and plant portions. $\mathrm{THg}$ and $\mathrm{MeHg}$ concentrations expressed on a dry weight (DW) basis are summarized in Table 3-5. THg concentrations in sediments were variable, but on the same order of magnitude at HAAF and China Camp sites. Mean sediment concentrations ranged from 304 to $407 \mathrm{ng} \mathrm{g}^{-1} \mathrm{DW}$. THg concentrations were generally lower in plant material than in sediments, and mean concentrations ranged in macrophytes between $18 \mathrm{ng} \mathrm{g}^{-1} \mathrm{DW}$ (S. foliosa stems) and $330 \mathrm{ng} \mathrm{g}^{-1} \mathrm{DW}$ (S. virginica roots), and in epipelon between 288 and $296 \mathrm{ng} \mathrm{g}^{-1} \mathrm{DW}$. THg concentrations varied greatly with plant organ, and were higher in roots than in aboveground plant organs.

$\mathrm{MeHg}$ concentrations in sediments were also variable, and on the same order of magnitude at HAAF and China Camp. Mean sediment concentrations ranged from 1.11 to $2.39 \mathrm{ng} \mathrm{g}^{-1} \mathrm{DW}$, and varied between 0.11 and 2.58 percent $\mathrm{THg}$. $\mathrm{MeHg}$ concentrations in the macrophytes usually exceeded those in the sediments in which they rooted, particularly when incubated under ambient irradiance. Mean MeHg concentrations in plant materials ranged between $1.01 \mathrm{ng} \mathrm{g}^{-1} \mathrm{DW}$ in $S$. foliosa leaves to $5.59 \mathrm{ng} \mathrm{g}^{-1} \mathrm{DW}$ in $S$. foliosa roots. Also in this case, concentrations varied greatly with plant organ, and were higher in roots than in aboveground plant organs. 


\begin{tabular}{|c|c|c|c|c|}
\hline \multicolumn{5}{|c|}{$\begin{array}{l}\text { Table 3-4 } \\
\text { Depth Profiles of in situ Redox Potential, Measured Just Outside } \\
\text { the Incubated Cores }\end{array}$} \\
\hline \multirow[b]{2}{*}{ Marsh Compartment } & \multicolumn{2}{|c|}{ HAAF } & \multicolumn{2}{|c|}{ China Camp } \\
\hline & $E_{h}(m V)$ & pH & $E_{h}(m V)$ & $\mathrm{pH}$ \\
\hline \multicolumn{5}{|l|}{ Nonvegetated sediment } \\
\hline$-2.5 \mathrm{~cm}$ & $-114(8)$ & $7.1(0)$ & -91 & 7.5 \\
\hline$-5 \mathrm{~cm}$ & $-202(74)$ & & -127 & \\
\hline$-10 \mathrm{~cm}$ & $-125(1)$ & & -112 & \\
\hline \multicolumn{5}{|c|}{ Epipelon-vegetated sediment } \\
\hline$-2.5 \mathrm{~cm}$ & -222 & 7.0 & $-114(0)$ & 7.0 \\
\hline \multicolumn{5}{|c|}{ Spartina root zone sediment } \\
\hline$-2.5 \mathrm{~cm}$ & $-245(48)$ & $7.1(0.3)$ & -248 & 7.0 \\
\hline$-5 \mathrm{~cm}$ & $-192(68)$ & & \begin{tabular}{|l|l|}
-104 \\
\end{tabular} & \\
\hline$-10 \mathrm{~cm}$ & $-242(59)$ & & -110 & \\
\hline \multicolumn{5}{|c|}{ Salicornia root zone sediment } \\
\hline$-2.5 \mathrm{~cm}$ & $-183(58)$ & $7.1(0.3)$ & $\mid-156$ & 7.1 \\
\hline$-5 \mathrm{~cm}$ & $-127(20)$ & & -127 & \\
\hline$-10 \mathrm{~cm}$ & $-217(93)$ & & -144 & \\
\hline
\end{tabular}

The THg concentrations in plant portions found in this study after 5-hr incubation are high relative to those measured in other studies, but the $\mathrm{MeHg}$ concentrations are in the same range as published for other wetlands. Values were 13-205 $\mathrm{ng} \mathrm{g}^{-1}$ for THg in aboveground, and 217-297 $\mathrm{ng} \mathrm{g}^{-1}$ in belowground biomass (Table 3-6). MeHg was 0.55-5.75 $\mathrm{ng} \mathrm{g}^{-1}$ in aboveground and 2.84-5.26 ng $\mathrm{g}^{-1}$ in belowground biomass. The high $\mathrm{THg}$ and $\mathrm{MeHg}$ values measured in the stems of $S$. foliosa are probably artifacts due to adhering sediment particles. For comparison, mercury levels measured in other wetland plants are provided. Mercury levels in plants from a freshwater wetland in Ontario, Canada, are 22 to $80 \mathrm{THg} \mathrm{ng} \mathrm{g} \mathrm{g}^{-1} \mathrm{DW}$ and 0.18 to $1.04 \mathrm{ng} \mathrm{g}^{-1} \mathrm{MeHg}$ DW (Heyes et al. 1998). Plants in Chapman's Marsh salt marsh in New Hampshire are 8 to $34 \mathrm{ng} \mathrm{g}^{-1} \mathrm{THg}$ DW, and 0.1 to $4 \mathrm{ng} \mathrm{g}^{-1} \mathrm{MeHg}$ DW (Heller and Weber 1998).

Light-dark comparison. In this study, concentrations of THg were higher in aboveground plant organs incubated in light than those incubated in darkness, particularly in the stems. In contrast, the concentrations were similar in roots incubated in the light and in darkness (Table 3-6). This may indicate transport of $\mathrm{THg}$ from roots to shoots is driven by light, possibly by increased evapotranspiration. These results support the recently suggested hypothesis that $\mathrm{Hg}^{0}$ emissions above cattail and sawgrass vegetation increase with increased evapotranspiration and photosynthesis, whereas emissions were negligible at night (Lindberg et al. 2002, Lindberg et al. 2005).

In the current study, the $\mathrm{MeHg}$ concentrations were higher in the aboveground plant organs of $S$. foliosa incubated in light compared to those incubated in darkness. There were no differences in mercury levels in the roots between light and dark incubations in the roots of S. foliosa. No difference was seen for 
Salicornia virginica. This may indicate a higher availability of $\mathrm{MeHg}$ in the sediment for uptake by $S$. foliosa, or a higher availability of energy in the plant species itself to fuel uptake and root-shoot transport.

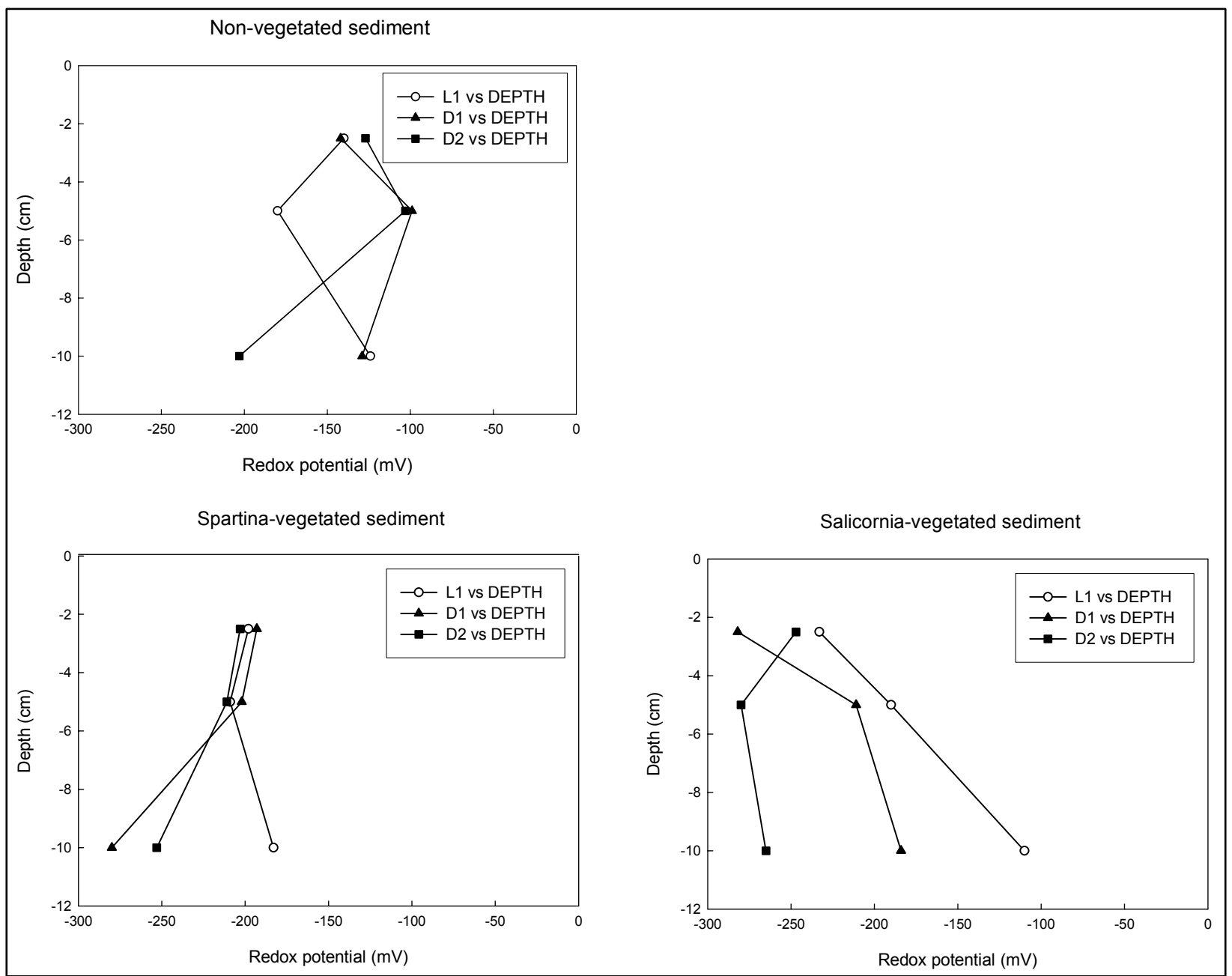

Figure 3-5. Depth profiles of redox potential in nonvegetated and vegetated sediment cores incubated in situ at HAAF in light (L) and in darkness (D)

\section{Rates of MeHg production}

Rates of methylation and demethylation in sediments of marsh zones. The standing pool sizes of $\mathrm{MeHg}$ are the difference between the rates of methylation of $\mathrm{Hg}^{2+}$ and demethylation of $\mathrm{MeHg}$. A mixture of ${ }^{199} \mathrm{Hg}^{2+}$ and $\mathrm{Me}^{200} \mathrm{Hg}$ was injected into three different sediment horizons and incubated the sediments in situ. It is assumed that ${ }^{199} \mathrm{Hg}^{2+}$ and $\mathrm{Me}^{200} \mathrm{Hg}$ were equally available to the microorganisms in the affected areas of the sediment. This method produces the best data on ratio of rates of methylation to demethylation currently available. However, because the ${ }^{199} \mathrm{Hg}^{2+}$ labeled tracer is diluted by the sedimentary pool size of mercury available for methylation, calculations of methylation rates require measures of mercury available for methylation. Since no one knows how to measure the size of the bioavailable mercury pool, it is assumed that the mer- 
cury in the sediment, $\mathrm{THg}$, is available for methylation. However, the amount of mercury available for methylation is probably only a fraction of $\mathrm{THg}$, and, therefore, these methylation rates may be considered as "potential" rates.

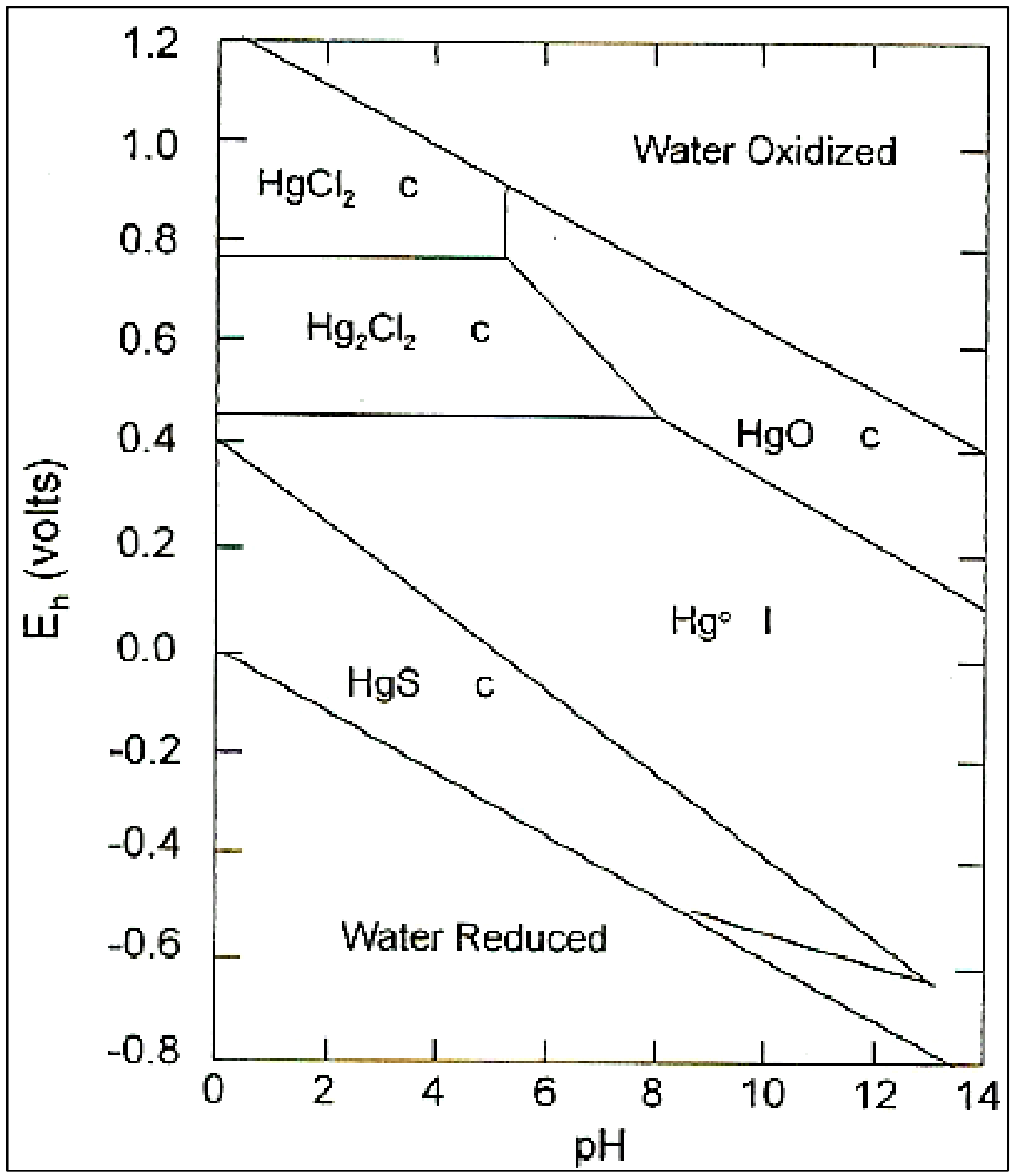

Figure 3-6. Abiotic conditions determining the various speciations of $\mathrm{Hg}$ 


\begin{tabular}{|c|c|c|c|c|}
\hline \multicolumn{5}{|c|}{$\begin{array}{l}\text { Table 3-5 } \\
\text { Total Hg and MeHg Levels in Two Existing Tidal Marshes Bordering } \\
\text { San Francisco Bay, in Sediment, Epipelic Algae, and Marsh } \\
\text { Vegetation }\end{array}$} \\
\hline \multirow[b]{2}{*}{ Marsh Compartment } & \multicolumn{2}{|c|}{ HAAF } & \multicolumn{2}{|c|}{ China Camp } \\
\hline & THg, $\mathbf{n g ~ g}^{-1} \mathrm{DW}$ & MeHg, ng g ${ }^{-1} \mathrm{DW}$ & THg, ng g $^{-1}$ DW & MeHg, ng g ${ }^{-1} \mathrm{DW}$ \\
\hline Nonvegetated sediment & $378(89)$ & $1.78(1.80)$ & 327(17) & 1.56(1.12) \\
\hline Epipelon & $296(51)$ & $1.27(0.25)$ & $288(12)$ & $7.42(3.72)$ \\
\hline \multicolumn{5}{|l|}{ Spartina foliosa } \\
\hline Sediment & $407(30)$ & $1.35(1.42)$ & $371(59)$ & $2.22(1.29)$ \\
\hline Roots (light) & $260(62)$ & $4.24(0.54)$ & $175(32)$ & $5.59(3.75)$ \\
\hline Stems (light) & $28(-)$ & $2.65(-)$ & $18(-)$ & $1.08(-)$ \\
\hline Leaves (light) & $17(10)$ & $0.68(0.36)$ & $39(25)$ & $0.90(0.35)$ \\
\hline \multicolumn{5}{|l|}{ Salicornia virginica } \\
\hline Sediment & $314(42)$ & $1.11(0.79)$ & $304(36)$ & $2.39(1.68)$ \\
\hline Roots (light) & $330(170)$ & $3.03(1.22)$ & $123(-)$ & $2.28(-)$ \\
\hline Stems (light) & $114(-)$ & $1.28(-)$ & $203(-)$ & $1.29(-)$ \\
\hline Leaves (light) & $24(12)$ & $1.01(0.58)$ & $18(5)$ & $0.95(0.24)$ \\
\hline \multicolumn{5}{|c|}{$\begin{array}{l}\text { Note: In HAAF, of the nonvegetated sediments, solids concentrations were } 36.9 \% \text { and loss on } \\
\text { ignition (LOI) } 19.6 \% \text {; of the vegetated sediments, solids concentrations were } 43.8 \% \text { and } L O I=16.4 \% \text {. } \\
\text { Mean values (SD; sediment, } N=9 \text {; roots, } N \geq 1 \text {; stems, } N \geq 1 \text {; leaves, } N=3 \text { ). }\end{array}$} \\
\hline
\end{tabular}

\section{Table 3-6 \\ Total $\mathrm{Hg}$ and MeHg Levels in Sediment and Marsh Vegetation After 5-hr Incubation in Ambient Light Conditions and in Darkness}

\begin{tabular}{|c|c|c|c|c|}
\hline \multirow{2}{*}{ Marsh Compartment } & \multicolumn{2}{|c|}{ THg, $\mathbf{n g ~ g}^{-1} \mathrm{DW}$} & \multicolumn{2}{|c|}{ MeHg, ng g ${ }^{-1} \mathrm{DW}$} \\
\hline & Light & Dark & Light & Dark \\
\hline \multicolumn{5}{|l|}{ Spartina foliosa } \\
\hline Sediment & $389(49)$ & $380(55)$ & $1.79(1.39)$ & $1.63(1.29)$ \\
\hline Roots & $217(64)$ & $224(81)$ & $4.92(2.51)$ & $5.26(1.71)$ \\
\hline Stems & $205(-)$ & $25(6)$ & $4.75(-)$ & $1.64(0.87)$ \\
\hline Leaves & $28(21)$ & $13(6)$ & $0.79(0.34)$ & $0.55(0.24)$ \\
\hline \multicolumn{5}{|l|}{ Salicornia virginica } \\
\hline Sediment & $310(38)$ & $304(37)$ & $1.75(1.44)$ & $1.18(0.87)$ \\
\hline Roots & $278(173)$ & $297(56)$ & $2.84(1.06)$ & $3.46(2.24)$ \\
\hline Stems & $158(62)$ & $54(30)$ & $1.28(0.01)$ & $1.20(0.41)$ \\
\hline Leaves & $21(9)$ & $38(20)$ & $0.98(0.40)$ & $1.02(0.19)$ \\
\hline
\end{tabular}

Data generated in this study and by others (Hintelmann et al. 2000) have shown that the MeHg standing pool size is very variable with respect to space and time. The first indication of this variability is seen in the relatively large standard deviations around mean $\mathrm{MeHg}$ measurements within a given habitat (e.g., Table 3-6). Since the standard error of this measurement on homogenized HAAF sediment was shown to be less than 5 percent, the observed standard deviations must represent the actual spatial heterogeneity. These standard deviations may have been reduced by slurrying the root zone sediments, but this would 
have probably resulted in artificially raising the rates measured. However, standard deviations were not wider than others recently reported.

The trends in mean rates of ${ }^{199} \mathrm{Hg}$ methylation consistently showed that photosynthetic activity increased the rates of $\mathrm{Hg}$ methylation in the root zones of $S$. foliosa and $S$. virginica in HAAF sediment (Tables 3-7 and 3-8). The same trend was seen for the sediment covered by an epipelic mat and sediments containing benthic algae without a visible algal mat cover. This trend was not obvious in China Camp sediments. No clear trend was noticeable in the mean rates of $\mathrm{Me}^{200} \mathrm{Hg}$ demethylation (Table 3-8). By recalculation of the methylation and demethylation rates on a dry sediment basis using the appropriate LOI values (Table 3-5, footnote), it was found that the methylation:demethylation ratio was greater than 1 in all sediments except sediment vegetated by $S$. virginica at China Camp (Table 3-9). The epipelon-vegetated sediments usually exhibited the highest ratio and the nonvegetated sediments the lowest ratio. The methylation: demethylation ratios found in this study for nonvegetated sediments are higher than those found by Marvin-DiPasquale et al. (2003), i.e. 1.12-6.45 versus 1.24. This study's methylation:demethylation ratio for vegetated sediments ranges from 0.87 to 2.78, whereas Marvin-DiPasquale et al. (2003) reported a ratio of 3.38 .

\section{Table 3-7}

Rates of Methylmercury Accumulation and Methylation in Nonvegetated and Vegetated Sediment in Two Existing Tidal Marshes

\begin{tabular}{|c|c|c|c|c|c|c|c|c|}
\hline \multirow[b]{3}{*}{ Sediment } & \multicolumn{4}{|c|}{ HAAF } & \multicolumn{4}{|c|}{ China Camp } \\
\hline & \multicolumn{2}{|c|}{$\begin{array}{l}\text { Me }{ }^{199} \mathrm{Hg} \mathrm{Accumulation} \\
\text { Rate, } \mathrm{ng} \mathrm{g}^{-1} \mathrm{DW} / 12 \mathrm{hr}\end{array}$} & \multicolumn{2}{|c|}{$\begin{array}{l}\text { Methylation Rate, } \\
\% \mathrm{Hg}^{2+} / 12 \mathrm{hr}\end{array}$} & \multicolumn{2}{|c|}{$\begin{array}{l}\mathrm{Me}^{199} \mathrm{Hg} \mathrm{Accumulation} \\
\text { Rate, } \mathrm{ng} \mathrm{g}^{-1} \mathrm{DW} / 12 \mathrm{hr}\end{array}$} & \multicolumn{2}{|c|}{$\begin{array}{l}\text { Methylation Rate, } \\
\% \mathrm{Hg}^{2+} / 12 \mathrm{hr}\end{array}$} \\
\hline & Light & Darkness & Light & Darkness & Light & Darkness & Light & Darkness \\
\hline $\begin{array}{l}\text { Nonvegetated } \\
\text { sediment }\end{array}$ & $0.21(0.19)$ & $0.13(0.10)$ & $0.25(0.27)$ & $0.12(0.09)$ & $3.73(2.69)$ & $4.97(4.39)$ & $1.12(0.79)$ & $1.43(1.13)$ \\
\hline $\begin{array}{l}\text { Epipelon- } \\
\text { vegetated } \\
\text { sediment }\end{array}$ & NA & NA & $0.75(0.30)$ & $0.54(0.13)$ & NA & NA & $4.61(2.95)$ & $6.07(1.70)$ \\
\hline $\begin{array}{l}\text { Spartina root zone } \\
\text { sediment }\end{array}$ & $0.26(0.33)$ & $0.10(0.14)$ & $0.22(0.28)$ & $0.13(0.15)$ & $0.19(0.12)$ & $0.12(0.11)$ & $0.23(0.16)$ & $0.20(0.11)$ \\
\hline $\begin{array}{l}\text { Salicornia root } \\
\text { zone sediment }\end{array}$ & $0.30(0.30)$ & $0.14(0.06)$ & $0.36(0.21)$ & $0.22(0.10)$ & $0.10(0.07)$ & $0.11(0.04)$ & $0.23(0.09)$ & $0.20(0.07)$ \\
\hline
\end{tabular}

Sedimentary microbial community biomass. Microorganisms are the agents that are primarily responsible for both the methylation of $\mathrm{Hg}^{2+}$ and the demethylation of $\mathrm{MeHg}$. In nonvegetated sediments microbial biomass rapidly decreases with depth. This trend was generally observed at HAAF (Table 3-10). Epipelic mats at the sediment-water interface resulted in very high biomass. Both epipelon and the macrophytes increased the levels of microbial biomass in the surface sediments when compared to that of the nonvegetated sediment. Penetration of the lower sediments by macrophyte roots supports a dense microbial community to depths of $10 \mathrm{~cm}$. The PLFAME analysis has been shown to give an accurate estimate of the microbial cells present in sediments because it 
does not require the cultivation of fastidious environmental microorganisms. Assuming 1 pmole of PLFAME is equivalent to $2.5 \times 10^{7}$ microbial cells (Pinkart et al. 2002), these sediments support relatively high microbial population $\left(>10^{9}\right.$ cells g $\left.{ }^{-1} \mathrm{DW}\right)$.

\begin{tabular}{|c|c|c|c|c|}
\hline \multicolumn{5}{|c|}{$\begin{array}{l}\text { Table 3-8 } \\
\text { Rates of Daily MeHg Degradation Rates in Nonvegetated and } \\
\text { Vegetated Sediment in Two Existing Tidal Marshes }\end{array}$} \\
\hline \multirow[b]{3}{*}{ Sediment } & \multirow{2}{*}{\multicolumn{2}{|c|}{$\begin{array}{c}\text { HAAF } \\
\mathrm{MeHg} \text { Degradation Rate } \\
\left(\% \mathrm{Me}^{200} \mathrm{Hg} \text { degraded/day }\right)\end{array}$}} & \multirow{2}{*}{\multicolumn{2}{|c|}{$\begin{array}{c}\text { China Camp } \\
\mathrm{MeHg} \text { Degradation Rate } \\
\left(\% \mathrm{Me}^{200} \mathrm{Hg} \text { degraded/day }\right)\end{array}$}} \\
\hline & & & & \\
\hline & Light & Darkness & Light & Darkness \\
\hline Nonvegetated sediment & $73(42)$ & $71(28)$ & $43(42)$ & $57(43)$ \\
\hline Epipelon-vegetated sediment & $87(6)$ & $78(7)$ & $99(1)$ & $100(1)$ \\
\hline Epipelon control sediment & $77(11)$ & & $90(4)$ & \\
\hline Spartina root zone sediment & $70(41)$ & $89(18)$ & $70(36)$ & $74(40)$ \\
\hline Salicornia root zone sediment & $63(39)$ & $55(29)$ & $59(46)$ & $68(38)$ \\
\hline
\end{tabular}

Sedimentary microbial community composition. Macrophytes not only affected levels and depth distributions of microbial community biomass but also affected the taxonomic composition of the uppermost sediments. The microbial community compositions of all surface sediment samples differed (Figure 3-7). The PLFAME profiles of epipelic mats were similar no matter where in HAAF they were collected. They were very different from those from surface sediments vegetated by $S$. foliosa that were in turn very different from those vegetated by $S$. virginica. The PLFAME community profiles of all the deeper sediments $(5-10 \mathrm{~cm})$ were similar to each other and most closely resembled those of the nonvegetated sediment. Sulfate-reducing bacteria of the genus Desulfobacter contain a unique PLFAME, 10-methyl 16:0 while those of the genus Desulfovibrio contain iso methyl branched 17:1. The relative abundances of these biomarker PLFAME indicate that Desulfobacter biomass was 10 times that of Desulfovibrio biomass in almost all sediments examined. Desulfobacter methylates $\mathrm{Hg}^{2+}$ faster than Desulfovibrio. Similar correlations have recently been shown for acid mine drainage-impacted streams in the California Coastal Range (Batten and Scow 2003).

\section{Factors controlling MeHg production}

The transfer of a methyl anion $\left(\mathrm{CH}_{3}^{-}\right)$group to a metal ion is not an easy reaction because $\mathrm{CH}_{3}{ }^{-}$is a strong, unstable base in aqueous solution. This reaction may be photochemically driven, but this is not seen as a significant environmental reaction mechanism in sediments. Microbial methylation of $\mathrm{Hg}$ is probably the main environmental source of $\mathrm{MeHg}$. Microbial methylation of $\mathrm{Hg}$ requires the presence of microorganisms capable of catalyzing the reaction, the physiological conditions conducive for active microbial metabolisms, and a biologically available source of $\mathrm{Hg}$. 


\begin{tabular}{|c|c|c|c|c|c|c|c|}
\hline \multicolumn{8}{|c|}{$\begin{array}{l}\text { Table 3-9 } \\
\text { Rates of Methylation, Demethylation, and Methylation:Demethylation Ratio in the } \\
\text { Sediment of the Existing Marsh Bordering the Two Sites }\end{array}$} \\
\hline \multirow[b]{2}{*}{ Sediment } & \multirow[b]{2}{*}{$\begin{array}{l}\mathrm{THg}^{1} \\
\mathrm{ng} \mathrm{g}^{-1} \mathrm{DW}\end{array}$} & \multirow[b]{2}{*}{$\begin{array}{l}\mathrm{MeHg}^{1} \\
\mathrm{ng} \mathrm{g}^{-1} \mathrm{DW}\end{array}$} & \multicolumn{2}{|c|}{ Methylation Rate Re $^{2,3}$} & \multicolumn{2}{|c|}{ Demethylation Rate Re $^{4,5}$} & \multirow[b]{2}{*}{$\begin{array}{l}\text { Meth:Demeth } \\
\text { Ratio }\end{array}$} \\
\hline & & & $\begin{array}{l}\% \mathrm{Hg}^{2+} \\
\text { per 12-hr }\end{array}$ & $\begin{array}{l}\mathrm{ng} \mathrm{g}^{-1} \mathrm{DW} \\
\text { per day }\end{array}$ & $\begin{array}{l}\% \mathrm{Me}^{200} \mathrm{Hg} \mathrm{deg} \\
\text { per day }\end{array}$ & \begin{tabular}{|l|}
$\mathrm{ng} \mathrm{g}^{-1} \mathrm{DW}$ \\
per day
\end{tabular} & \\
\hline \multicolumn{8}{|c|}{ HAAF } \\
\hline $\begin{array}{l}\text { Nonvegetated } \\
\text { sediment }\end{array}$ & 378 & 1.78 & 0.19 & 1.44 & 72 & 1.282 & 1.12 \\
\hline $\begin{array}{l}\text { Epipelon-vegetated } \\
\text { sediment }\end{array}$ & 296 & 1.27 & 0.65 & 3.85 & 83 & 1.054 & 3.65 \\
\hline $\begin{array}{l}\text { Epipelon control } \\
\text { sediment }\end{array}$ & 341 & 1.14 & 0.61 & 4.16 & 77 & 0.878 & 4.74 \\
\hline $\begin{array}{l}\text { Spartina root zone } \\
\text { sediment }\end{array}$ & 407 & 1.35 & 0.18 & 1.47 & 80 & 1.080 & 1.36 \\
\hline $\begin{array}{l}\text { Salicornia root zone } \\
\text { sediment }\end{array}$ & 314 & 1.11 & 0.29 & 1.82 & 59 & 0.655 & 2.78 \\
\hline \multicolumn{8}{|c|}{ China Camp } \\
\hline $\begin{array}{l}\text { Nonvegetated } \\
\text { sediment }\end{array}$ & 327 & 1.56 & 0.77 & 5.0358 & 50 & 0.780 & 6.46 \\
\hline $\begin{array}{l}\text { Epipelon-vegetated } \\
\text { sediment }\end{array}$ & 288 & 7.42 & 5.34 & 30.7584 & 100 & 7.420 & 4.15 \\
\hline $\begin{array}{l}\text { Epipelon control } \\
\text { sediment }\end{array}$ & 350 & 3.78 & 1.03 & 7.21 & 90 & 3.402 & 2.12 \\
\hline $\begin{array}{l}\text { Spartina root zone } \\
\text { sediment }\end{array}$ & 371 & 2.22 & 0.22 & 1.6324 & 72 & 1.598 & 1.02 \\
\hline $\begin{array}{l}\text { Salicornia root zone } \\
\text { sediment }\end{array}$ & 304 & 2.39 & 0.22 & 1.3376 & 64 & 1.530 & 0.87 \\
\hline \multicolumn{8}{|c|}{$\begin{array}{l}\text { Average light values (HAAF - Table 6) } \\
{ }^{2} \text { Average light and dark values (Table 7) } \\
{ }^{3} \text { Based on the assumption that microbes use isotopic } \mathrm{Hg}^{2+} \text { the same way as } \mathrm{THg} \\
{ }^{4} \text { Average light and dark values (Table 8) } \\
{ }^{5} \text { Based on the assumption that microbes use isotopic } \mathrm{MeHg} \text { the same way as } \mathrm{MeHg} \text {. }\end{array}$} \\
\hline
\end{tabular}

A large and growing amount of circumstantial evidence has been amassed implicating sulfate-reducing bacteria as the primary agents of the environmental production of methyl mercury. Sulfate-reducing bacteria (SRB) are anaerobes that oxidize a limited range of organic substrates. They use sulfate as a terminal electron acceptor for their respiration and produce sulfide. Molybdate, a specific inhibitor of sulfate respiration, has been repeatedly shown to simultaneously inhibit mercury methylation. Desulfovibrio desulfuricans LS is believed to transfer a methyl group originating from serine or the acetyl-CoA synthesis pathway through methyl-tetrahydrofolate and cobalamin to Hg. However, not all SRB methylate $\mathrm{Hg}$. Those that do, do so at very different rates. Marine sediments amended with acetate produced more methyl mercury than those amended with lactate. The SRB that can completely oxidize acetate (e.g., Desulfobacter) appear to be more proficient at methylating mercury than the lactate-oxidizing SRB that are unable to use acetate (Desulfovibrio). However, there appear to be many exceptions to this generalization. If $\mathrm{Hg}$ methylation proved to the SRB an energetic metabolic advantage, then the number of mercury-methylating SRB would be expected to increase to completely exploit the niche. 


\begin{tabular}{|c|c|c|}
\hline \multicolumn{3}{|c|}{$\begin{array}{l}\text { Table 3-10 } \\
\text { Total Microbial Biomass in Sediments, for Which Polar Lipid Fatty } \\
\text { Acids Methyl Ester (PLFAME) Content is Taken as a Measure }\end{array}$} \\
\hline \multirow{2}{*}{ Sediment } & \multicolumn{2}{|c|}{ Microbial Biomass, pmole PLFAME g $^{-1}$ DW } \\
\hline & HAAF & China Camp \\
\hline \multicolumn{3}{|c|}{ Nonvegetated sediment } \\
\hline$-2.5 \mathrm{~cm}$ & $4,022(185)$ & $22,884(770)$ \\
\hline$-5 \mathrm{~cm}$ & $2,564(124)$ & $14,333(454)$ \\
\hline$-10 \mathrm{~cm}$ & $2,172(715)$ & $20,609(596)$ \\
\hline \multicolumn{3}{|c|}{ Epipelon-vegetated sediment } \\
\hline$-2.5 \mathrm{~cm}$ & $25,965(382)$ & $35,367(639)$ \\
\hline$-5 \mathrm{~cm}$ & $6,253(-)$ & $8,846(-)$ \\
\hline \multicolumn{3}{|c|}{ Spartina root zone sediment } \\
\hline$-2.5 \mathrm{~cm}$ & $18,394(217)$ & $19,762(838)$ \\
\hline$-5 \mathrm{~cm}$ & $7,119(174)$ & $7,980(127)$ \\
\hline$-10 \mathrm{~cm}$ & $6,874(-)$ & ND \\
\hline \multicolumn{3}{|c|}{ Salicornia root zone sediment } \\
\hline$-2.5 \mathrm{~cm}$ & $18,577(328)$ & $22,102(338)$ \\
\hline$-5 \mathrm{~cm}$ & $9,385(201)$ & $31,932(993)$ \\
\hline$-10 \mathrm{~cm}$ & $7,994(348)$ & $20,001(772)$ \\
\hline \multicolumn{3}{|c|}{$\begin{array}{l}\text { Note: ND, not determined } \\
\text { Mean values (SD; } N=3 \text { ). }\end{array}$} \\
\hline
\end{tabular}

The availability of reactive $\mathrm{Hg}$ species that are available to the methylating SRB may be the rate-limiting factor in the environment. No active transport system for $\mathrm{Hg}$ has been demonstrated for the $\mathrm{Hg}$ methylating SRB. Membrane diffusion of neutral, lipophilic $\mathrm{Hg}$ species is believed to be the way Hg enters SRB. However, a very large number of $\mathrm{Hg}$ species can exist in natural waters and their behavior is complex. $\mathrm{HgCl}_{2}\left(\mathrm{~K}_{\mathrm{ow}}=3.3\right)$ is believed to be an important species for membrane transport in oxic waters (Morel et al. 1998). $\mathrm{HgCl}_{2}$ relative abundance is affected by the levels of chloride ion (salinity). Environmental sulfide levels are probably also a major determinant of the bioavailability of $\mathrm{Hg}$ to SRB. Water-soluble $\mathrm{Hg}$ complexes include $\mathrm{HgS}^{0}, \mathrm{Hg}(\mathrm{SH})_{2}{ }^{0}, \mathrm{Hg}(\mathrm{SH})^{+}, \mathrm{HgS}_{2}{ }^{2+}$ and $\mathrm{HgHS}_{2}^{-}$(Benoit et al. 2003). Increasing the sulfide level drives the water chemistry so as to favor the charged mercury-sulfide complexes at the expense of the neutral complexes. This decreases the availability of $\mathrm{Hg}$ to SRB and would reduce rates of methylation. This leads to a situation that has been reported in the Everglades. The highest levels of $\mathrm{Hg}$ methylation and highest levels of $\mathrm{MeHg}$ in fish are found associated with sediments showing intermediate levels of sulfate and rates of sulfate reduction. Rates of $\mathrm{Hg}$ methylation and levels of $\mathrm{MeHg}$ in fish are lower in areas where intense sulfate respiration produces levels of sulfide that in turn decrease the availability of $\mathrm{Hg}$ to SRB (Benoit et al. 2003).

From this short discussion it can be realized that there is still much to learn about the mechanisms that drive environmental $\mathrm{Hg}$ methylation. However, some hypotheses related to engineering means in order to mitigate $\mathrm{MeHg}$ production in wetlands can be tested. 


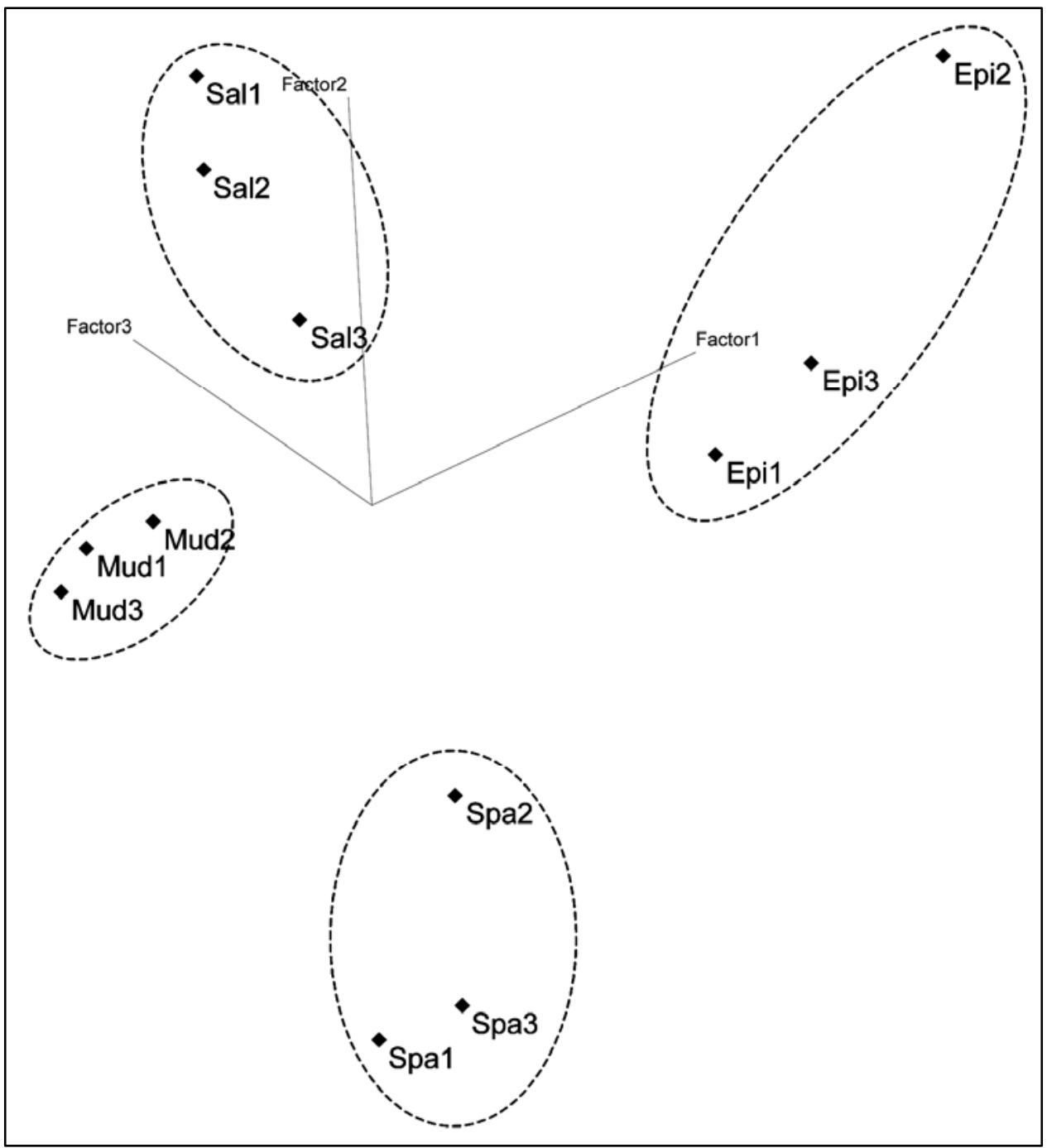

Figure 3-7. Principal Component Analysis reveals groupings among triplicate samples of top layers of sediment cores from the indicated vegetative zones. The axes of the plot are the first three principal component factors

\section{Initial answers to questions raised at the CALFED Stakeholders Workshop on Mercury in San Francisco Bay, 8-9 October 2002, Moss Landing Marine Laboratories}

While the environmental risk posed by the potential transport of mercury from dredged material into the HAAF food web is the immediate concern of this study, the potential cumulative impact of $\mathrm{Hg}$ from dredged materials and other sources in the context of the numerous ongoing and proposed wetland restorations on San Francisco Bay is an overarching concern. For both of these ends, a mass balance of $\mathrm{Hg}$ for the HAAF wetlands would be useful. This section is meant to stimulate thought and identify critical gaps in knowledge of wetland $\mathrm{Hg}$ biogeochemistry with respect to physical/biological processes and trophic transfer of $\mathrm{Hg}$ from reconstructed wetlands into San Francisco Bay. The 
numerical values in these processes may change as the assumptions are replaced by measured or calculated values.

What are the present levels of MeHg in SF Bay wetlands with respect to biota, sub-habitats, and location within the bay? Mean $\mathrm{MeHg}$ concentrations in sediments were on the same order of magnitude at HAAF and China Camp, and ranged from 1.11 to $2.39 \mathrm{ng} \mathrm{g}^{-1} \mathrm{DW}$. Mean $\mathrm{MeHg}$ concentrations in the macrophytes varied between $1.01 \mathrm{~S}$. V. leaves to $5.59 \mathrm{ng} \mathrm{g}^{-1} \mathrm{DW}$ in $S$. foliosa roots. They usually exceeded those in the sediments in which they rooted, particularly when incubated under ambient irradiance.

Based on the levels of mercury measured in this study a projection was calculated of the levels and distribution of mercury species in the HAAF marsh once it is reconstructed (Table 3-11). To create this projection it was assumed that the 10.6 million cubic yards of dredged material needed to elevate the HAAF site (Phillip Williams and Associates 1998) will contain the same levels of THg and $\mathrm{MeHg}$ currently in the HAAF surface sediments. It was also assumed that this will be the primary source of $\mathrm{Hg}$. This assumption is simplistic. If the source of the dredged material is the geological formation to be excavated for the expansion of the Oakland Harbor, the level of $\mathrm{Hg}$ in this material will be far lower. Sediment trapped by the HAAF wetland as it develops will originate up the North Bay rivers and contain levels of $\mathrm{Hg}$ comparable to those currently in North Bay surficial sediments. The amounts and bioavailability for methylation of atmospherically deposited $\mathrm{Hg}$ is currently unclear and was considered for this projection.

In 2005, when the dredged material has been deposited into the target area and the initial wetland construction activities have been completed, the total aerial surface of the HAAF wetland will be approximately $203 \mathrm{Ha}$. The top $(0-10 \mathrm{~cm})$ of sediment will weigh $81.2 \times 10^{6} \mathrm{~kg}$ (dry weight), and (based on the above assumption) contain $30.7 \mathrm{~kg}$ of THg and $0.145 \mathrm{~kg}$ of MeHg (Table 3-11).

Standing crop values of $1 \mathrm{~kg} \mathrm{DW} \mathrm{m}^{-2}$ for aboveground and $1 \mathrm{~kg} \mathrm{DW} \mathrm{m}^{-2}$ for belowground macrophyte mass have been used for the marsh mass balance estimates (Table 3-1). S. foliosa will initially colonize HAAF and by 2015 occupy $117 \mathrm{ha}$ and produce a biomass of $2.34 \times 10^{6} \mathrm{~kg}$ dry weight (DW). At this point in time $S$. virginica will have colonized 86 ha and constitute a biomass of $1.72 \times$ $10^{6} \mathrm{~kg}$. The current average levels of mercury in these plants are as follows. $S$. foliosa standing stock will contain $90 \mathrm{ng} \mathrm{THg}$ and $2.52 \mathrm{ng} \mathrm{MeHg}$ per gram DW. S. virginica will contain $135 \mathrm{ng} \mathrm{THg}$ and $1.64 \mathrm{ng} \mathrm{MeHg}$ per gram DW. Based on present plant tissue levels the year 2015 S. foliosa biomass will contain $211 \mathrm{~g}$ of THg and $5.9 \mathrm{~g}$ of MeHg. Likewise the $S$. virginica biomass will contain approximately $232 \mathrm{~g}$ of THg and $2.8 \mathrm{~g}$ of MeHg (Table 3-11). In 2015, only 1.4 percent of the THg and 5.7 percent of the $\mathrm{MeHg}$ standing stocks of the system will be in the plant mass, while the remainder will reside in the top 0 - to 10-cm sediment layer.

The mass balance of mercury in HAAF during 2055 shown in Table 3-11 assumes little change from the current distributions and levels in sediment and vegetation due to the increase in wetland aerial surface area. This table puts into perspective the mass of $\mathrm{THg}$ and $\mathrm{MeHg}$ in the surface sediments that is poten- 
tially available to the HAAF food web. It shows macrophytic marsh vegetation as a dominant biological presence in the marsh. $\mathrm{THg}$ and $\mathrm{MeHg}$ contents in macrophytes amount to 2 and 4 percent, respectively, of contents in surficial sediments. Perhaps most significantly, given the role of macrophyte biomass in wetland trophodynamics, it shows that the sediment - plant exposure route is potentially an important route for $\mathrm{Hg}$ to enter the wetland food web.

\begin{tabular}{|c|c|c|c|c|c|c|c|c|c|}
\hline \multicolumn{10}{|l|}{$\begin{array}{l}\text { Table 3-11 } \\
\text { Estimated }\end{array}$} \\
\hline Compartment & $\begin{array}{l}\text { Area } \\
\text { HAAF, } \\
\text { ha }\end{array}$ & $\begin{array}{l}\mathrm{THg} \text {, } \\
\mathrm{ng} \mathrm{g}^{-1} \mathrm{DW}\end{array}$ & $\begin{array}{l}\text { MeHg, } \\
\text { ng g }^{-1} \text { DW }\end{array}$ & $\begin{array}{l}\text { Mass, } \\
\text { kg DW ha }{ }^{-1} \\
\end{array}$ & $\begin{array}{l}\text { Mass, } \\
\text { kg DW }\end{array}$ & THg, $\mathbf{g}$ & $\begin{array}{l}\text { THg, } \\
\% \text { system }\end{array}$ & $\begin{array}{l}\text { MeHg, } \\
\text { g }\end{array}$ & $\begin{array}{l}\text { MeHg, } \\
\% \text { system }\end{array}$ \\
\hline \multicolumn{10}{|c|}{ Year 2005} \\
\hline $\begin{array}{l}\text { Sediment } \\
(0->10 \mathrm{~cm})^{1}\end{array}$ & 203 & 378 & 1.78 & 400,000 & $81.2 \times 10^{6}$ & $30,693.6$ & 100 & 144.5 & 100 \\
\hline Spartina veg. ${ }^{1}$ & & 90 & 2.52 & 20,000 & 0 & 0 & 0 & & 0 \\
\hline Salicornia veg. ${ }^{1}$ & & 135 & 1.64 & 20,000 & 0 & 0 & 0 & & 0 \\
\hline Total & 203 & & & & & $30,693.6$ & & 144.5 & \\
\hline \multicolumn{10}{|c|}{ Year 2015} \\
\hline $\begin{array}{l}\text { Sediment } \\
(0->10 \mathrm{~cm})^{1}\end{array}$ & 203 & 378 & 1.78 & 400,000 & $81.2 \times 10^{6}$ & $30,693.6$ & 98.6 & 144.5 & 94.3 \\
\hline Spartina veg. ${ }^{1}$ & 117 & 90 & 2.52 & 20,000 & $2.34 \times 10^{6}$ & 210.6 & 0.68 & 5.9 & 3.8 \\
\hline Salicornia veg. ${ }^{1}$ & 86 & 135 & 1.64 & 20,000 & $1.72 \times 10^{6}$ & 232.2 & 0.75 & 2.8 & 1.8 \\
\hline Total & 203 & & & & & $31,136.4$ & & 153.3 & \\
\hline \multicolumn{10}{|c|}{ Year 2055} \\
\hline $\begin{array}{l}\text { Sediment } \\
(0->10 \mathrm{~cm})^{1}\end{array}$ & 203 & 378 & 1.78 & 400,000 & $812 \times 10^{6}$ & $30,693.6$ & 98.2 & 144.5 & 95.6 \\
\hline Spartina veg. ${ }^{1}$ & 0 & 90 & 2.52 & 20,000 & 0 & 0 & 0 & 0 & 0 \\
\hline Salicornia veg. ${ }^{1}$ & 203 & 135 & 1.64 & 20,000 & $4.06 \times 10^{6}$ & \begin{tabular}{|l|}
548.1 \\
\end{tabular} & 1.75 & 6.7 & 4.4 \\
\hline Total & 203 & & & & & $31,241.7$ & & 151.2 & \\
\hline
\end{tabular}

What are the rates of $\mathrm{MeHg}$ production? Net $\mathrm{MeHg}$ production is the result of methylation and demethylation rates in the sediment. Methylation rates were $1.44 \mathrm{ng} \mathrm{MeHg} \mathrm{g}^{-1} \mathrm{DW}$ per day in nonvegetated sediments of HAAF (Table 3-9). Rates were usually lower in vegetated than in nonvegetated sediments. Rates were usually higher in the light than in darkness. Methylation rates varied with location within the bay, and were lower on bare and epipelonvegetated sites at HAAF than at China Camp. Demethylation rates were $1.282 \mathrm{ng}$ $\mathrm{MeHg} \mathrm{g}^{-1} \mathrm{DW}$ per day in nonvegetated sediments at HAAF and $0.78 \mathrm{ng} \mathrm{MeHg} \mathrm{g}$ ${ }^{1}$ DW per day at China Camp (Table 3-9). Rates were equal or lower in vegetated sediments.

What factors control MeHg production? Although a number of plausible mechanisms have been proposed (see discussion above), no data currently exist to support any proposed mechanism. Data trends suggest methylation and demethylation rates are higher in the sediment surface layers than in deeper 
layers. In the surface layers, the microbial biomass is also highest, and the composition of the microbial communities is strongly influenced by the presence/ absence of vegetation, and by the vegetating species (epipelon, $S$. foliosa, $S$. virginica). The largest variations in redox potential due to tidal inundation and plant-sediment interactions also occur in the surface layer. Work to find answers to this important question will be continued.

Can the effects of wetland restoration on $\mathrm{MeHg}$ production and export be predicted? Are some wetlands larger mercury exporters than others? After placing the dredged material into the HAAF and breaching the dike, suspended sediments from the bay will enter HAAF. HAAF must be structured to trap sediments if the saltmarsh is to become sustainable. During the initial 10 years (2005-2015), the marsh plain will be composed largely of nonvegetated sediment (Phillip Williams and Associates 1996). This sediment will be exposed to regular tides at elevations below MHW. Sediments at higher elevations will be wetted only by higher tides and storms. During this period these elevations will be primarily vegetated by epipelon that can greatly affect the cycling of $\mathrm{Hg}$ and $\mathrm{MeHg}$ in and export from the wetland. In this study it was found that the methylation:demethyation ratio in epipelon-vegetated sediments is far higher than of bare and macrophyte-vegetated sediments (Table 3-9). A high net $\mathrm{MeHg}$ production would be expected and these high food quality algal mats would probably be associated with efficient $\mathrm{MeHg}$ trophic transfer. However, at present, data on the biomass of epipelon per square meter basis and efficiency of trophic transfer are lacking. Thus, it is not possible to estimate how large the epipelonvegetated part will be, and, therefore, these values have not been used in the following projections.

To identify gaps in knowledge required to produce useful estimates of $\mathrm{MeHg}$ export from saltmarshes, initial estimates of $\mathrm{MeHg}$ export from HAAF were made noting the assumptions required to make this estimate. Assuming that the entire HAAF will be intertidal and nonvegetated, and that the tides will export 0.8 percent of the net $\mathrm{MeHg}$ (Brannon et al. 1980) produced in the upper $5 \mathrm{~cm}$ of the sediment to the Bay per year, a potential net export of $18 \mathrm{~g} \mathrm{MeHg}$ per year is calculated (Table 3-12). Storms are expected to increase the amounts of THg and $\mathrm{MeHg}$ exported into the bay, since sediments will be contacted to greater depths than $5 \mathrm{~cm}$ by waves. The 0.8 percent value is obviously a critical value that must be validated with HAAF sediment. Lower exchange rates of $\mathrm{THg}$ and $\mathrm{MeHg}$ between bay sediments and tidal waters have been published recently by Choe et al. (2004). The latter values have not yet been included in the mass balance estimates. Additionally, $\mathrm{Hg}$ volatilization from $\mathrm{HAAF}$ sediment and vegetation has not been measured, but it is expected to be a quantitatively significant process. Volatilization was recently measured above the vegetation in the freshwater wetlands in the Everglades and amounted to 1-to 2-ng THg m${ }^{-2} \mathrm{~h}^{-1}$ during daylight hours (Lindberg et al. 2002). Based on these values, volatilization in a system of the HAAF size would be $89 \mathrm{~g}$ THg per year. This amount would be somewhat higher than $\mathrm{MeHg}$ predicted to be flushed from HAAF in tidal waters. 


\begin{tabular}{|c|c|c|c|c|c|c|c|c|}
\hline \multicolumn{9}{|c|}{$\begin{array}{l}\text { Table 3-12 } \\
\text { Estimated Potential MeHg Export of Tidal Marsh Areas in the Restored HAAF, Using } \\
\text { Values from this Study }\end{array}$} \\
\hline Compartment & $\begin{array}{l}\text { Area } \\
\text { HAAF, } \\
\text { ha }\end{array}$ & $\begin{array}{l}\text { Total } \\
\text { Mass, } \\
\text { kg DW }\end{array}$ & $\begin{array}{l}\text { Methylation } \\
\text { Rate }{ }^{1} \\
\mu \text { g/kg DW/day }\end{array}$ & $\begin{array}{l}\text { Demethylation } \\
\text { Rate }^{1} \text {, } \\
\mu \mathrm{g} / \mathrm{kg} \text { DW/day }\end{array}$ & $\begin{array}{l}\text { Net MeHg } \\
\text { Production } \\
\text { Rate, } \\
\mu \mathrm{g} / \mathrm{kg} \text { DW/day }\end{array}$ & $\begin{array}{l}\text { Net MeHg } \\
\text { Production } \\
\text { Rate, } \\
\text { g/system/yr }\end{array}$ & $\begin{array}{l}\text { MeHg Plant } \\
\text { Decomp. } \\
\text { Rate }^{3} \text {, } \\
\text { g/system/yr }\end{array}$ & $\begin{array}{l}\text { Total MeHg } \\
\text { Potential } \\
\text { Export to } \\
\text { Bay, } \\
\text { g/system/yr }\end{array}$ \\
\hline \multicolumn{9}{|c|}{ Year 2005} \\
\hline $\begin{array}{l}\text { Sediment } \\
(0->5 \mathrm{~cm})\end{array}$ & 203 & $40.6 \times 10^{6}$ & 1.436 & 1.281 & 0.155 & 2,294 & 0 & \\
\hline $\begin{array}{l}\text { Potential } \\
\text { export }^{2}\end{array}$ & & & & & & 18 & 0 & 18 \\
\hline \multicolumn{9}{|c|}{ Year 2015} \\
\hline $\begin{array}{l}\text { Sediment } \\
(0->5 \mathrm{~cm})\end{array}$ & 0 & 0 & 1.436 & 1.281 & 0.155 & 0 & & \\
\hline $\begin{array}{l}\text { Spartina- } \\
\text { veg.sed. }\end{array}$ & 117 & $23.4 \times 10^{6}$ & 1.465 & 1.060 & 0.385 & 3,290 & & \\
\hline $\begin{array}{l}\text { Salicornia- } \\
\text { veg.sed. }\end{array}$ & 86 & $17.2 \times 10^{6}$ & 1.821 & 0.655 & 1.166 & 7,322 & & \\
\hline Spartina-veg. & 117 & $2.34 \times 10^{6}$ & & & & & 2.95 & \\
\hline $\begin{array}{l}\text { Salicornia- } \\
\text { veg. }\end{array}$ & 86 & $1.72 \times 10^{6}$ & & & & & 1.41 & \\
\hline $\begin{array}{l}\text { Potential } \\
\text { export }^{2}\end{array}$ & & & & & & 85 & 4.36 & 89 \\
\hline \multicolumn{9}{|c|}{ Year 2055} \\
\hline $\begin{array}{l}\text { Sediment } \\
(0->5 \mathrm{~cm})\end{array}$ & 0 & & 1.436 & 1.281 & 0.155 & 0 & & \\
\hline $\begin{array}{l}\text { Spartina- } \\
\text { veg.sed. }\end{array}$ & 0 & & 1.465 & 1.060 & 0.385 & 0 & & \\
\hline $\begin{array}{l}\text { Salicornia- } \\
\text { veg.sed. }\end{array}$ & 203 & $40.6 \times 10^{6}$ & 1.821 & 0.655 & 1.166 & 17,283 & & \\
\hline Spartina-veg. & 0 & & & & & & 0 & \\
\hline $\begin{array}{l}\text { Salicornia- } \\
\text { veg. }\end{array}$ & 203 & $4.06 \times 10^{6}$ & & & & & 4.36 & \\
\hline $\begin{array}{l}\text { Potential } \\
\text { export }^{2}\end{array}$ & & & & & & 138 & 4.36 & 143 \\
\hline \multicolumn{9}{|c|}{$\begin{array}{l}1 \text { Data from Table 3-9 } \\
2 \text { Export from surficial sediments estimated at } 0.8 \% \text { of net MeHg production per day. This estimate is derived as follows: the water- } \\
\text { exchangeable fraction of } \mathrm{THg} \text { is } 0.35 \% \text { (Brannon et al. } 1980 \text { ). MeHg is slightly more water-soluble than } \mathrm{THg} \text {, i.e. } 0.40 \% \text {. MeHg is } \\
\text { exposed two times per day to tidal waters. }\end{array}$} \\
\hline
\end{tabular}

Succession of macrophytic communities in HAAF is predicted to result in a system dominated by $S$. virginica by 2055 . The vegetation contributes via three different routes to the export of $\mathrm{MeHg}$ from the wetland. First of all, the standing biomass will contribute daily relatively small amounts of $\mathrm{THg}$ and $\mathrm{MeHg}$ to the export by leaching processes. These amounts are expected to be at least 10 percent of the internal $\mathrm{THg}$ and $\mathrm{MeHg}$ concentrations in the aboveground plant material per day, values commonly published for nutrients. Far higher values for $\mathrm{Hg}$-leaching have been found for another plant species commonly found in saltmarshes, S. alterniflora (Windham et al. 2001). Based on the 10-percent leaching values, leaching amounts of $0.029 \mathrm{~g} \mathrm{THg} / \mathrm{day}$ and $0.00015 \mathrm{MeHg} / \mathrm{day}$ 
are expected. However, since it is not clear if these amounts are available for export or directly reabsorbed by the vegetation upon reaching the sediment, these amounts have not been included in current export estimates. Secondly, a large part of the plant biomass will scenesce, and almost all aboveground plant litter of $S$. foliosa will be exported into the bay during storms in winter and spring. Scenescence and decomposition of $S$. virginica will be a more gradual, but continuous, process throughout the year. The contribution of the vegetation to the $\mathrm{MeHg}$ export from the marsh via decomposition processes would amount to $4.36 \mathrm{~g} \mathrm{MeHg}$ per year in 2015 and 2055 (Table 3-12). Thirdly, volatilization of $\mathrm{THg}$ from the vegetation is expected. Volatilization was not measured in $S$. foliosa and S. virginica, and, therefore, better estimates than indicated above cannot be made at this time.

The current goal is to identify the key processes and values required to make useful estimates of $\mathrm{MeHg}$ export and provide initial estimates only for this purpose. These initial estimates are not intended to be used as quantitative values. From estimates on $\mathrm{MeHg}$ standing stocks and potential export from a restored HAAF wetland, it is obvious that values of net $\mathrm{MeHg}$ production in surficial sediments are crucial. Aside from the values provided herein, little other data are available. However, one recent study reports values on methylation, demethylation rates, and ratios measured in surficial bay sediments and in one marsh site, obtained using the less sensitive ${ }^{14} \mathrm{C}$-method (Marvin-DiPasquale et al. 2003). Using the latter values, the estimates of annual potential $\mathrm{MeHg}$ export would change significantly, from $2.5 \mathrm{~g} \mathrm{MeHg}$ for a nonvegetated HAAF to $405 \mathrm{~g} \mathrm{MeHg}$ for a vegetated HAAF (Table 3-13). The latter export would be 2.5 times higher than projected using the values generated by the study. Reasons for the differences in methylation, demethylation rates, and methylation:demethylation ratios in this study and in the Marvin-DiPasquale et al. (2003) study may be the following:

a. A more sensitive stable isotope approach has been used in the current study than the radioactive isotope approach used by Marvin-DiPasquale et al. (2003), therefore methylation rates are above the method-detection level, whereas the methylation rates measured by Marvin-DiPasquale et al. (2003) in bay sediments are below their higher detection level.

$b$. The nonvegetated bay sediments assayed in the current study originate from the marsh currently bordering the HAAF that are richer in organic matter and have a higher LOI than the bay sediments assayed by Marvin-DiPasquale et al. (2003), possibly causing higher methylation rates. This comparison demonstrates the sensitivity of this value to $\mathrm{MeHg}$ export projections. 


\begin{tabular}{|c|c|c|c|c|c|c|c|c|}
\hline \multicolumn{9}{|c|}{$\begin{array}{l}\text { Table 3-13 } \\
\text { Estimated Potential MeHg Export of Tidal Marsh Areas in the Restored HAAF, Using } \\
\text { Values from Marvin-DiPasquale et al. (2003) for Methylation and Demethylation Rates }\end{array}$} \\
\hline Compartment & $\begin{array}{l}\text { Area } \\
\text { HAAF, } \\
\text { ha }\end{array}$ & $\begin{array}{l}\text { Total } \\
\text { Mass, } \\
\text { kg DW }\end{array}$ & $\begin{array}{l}\text { Methylation } \\
\text { Rate }^{1} \\
\mu \mathrm{g} / \mathrm{kg} \text { DW/day }\end{array}$ & $\begin{array}{l}\text { Demethylation } \\
\text { Rate }^{1} \text {, } \\
\mu \mathrm{g} / \mathrm{kg} \text { DW/day }\end{array}$ & $\begin{array}{l}\text { Net MeHg } \\
\text { Production } \\
\text { Rate, } \\
\mu \mathrm{g} / \mathrm{kg} \text { DW/day } \\
\end{array}$ & $\begin{array}{l}\text { Net } \mathrm{MeHg} \\
\text { Production } \\
\text { Rate, } \\
\text { g/system/yr } \\
\end{array}$ & $\begin{array}{l}\text { MeHg Plant } \\
\text { Decomp. } \\
\text { Rate }^{3}, \\
\text { g/system/yr }\end{array}$ & $\begin{array}{l}\text { Total MeHg } \\
\text { Potential } \\
\text { Export, } \\
\text { g/system/yr } \\
\end{array}$ \\
\hline \multicolumn{9}{|c|}{ Year 2005} \\
\hline $\begin{array}{l}\text { Sediment } \\
(0->5 \mathrm{~cm})\end{array}$ & 203 & $40.6 \times 10^{6}$ & 0.108 & 0.087 & 0.021 & 311.199 & 0 & \\
\hline $\begin{array}{l}\text { Potential } \\
\text { export }^{2}\end{array}$ & & & & & & 2.5 & 0 & 2.5 \\
\hline \multicolumn{9}{|c|}{ Year 2015} \\
\hline $\begin{array}{l}\text { Sediment } \\
(0->5 \mathrm{~cm})\end{array}$ & 0 & 0 & 0.108 & 0.087 & 0.021 & 0 & & \\
\hline $\begin{array}{l}\text { Spartina- } \\
\text { veg.sed. }\end{array}$ & 117 & $23.4 \times 10^{6}$ & 4.824 & 1.442 & 3.382 & 28,886 & & \\
\hline $\begin{array}{l}\text { Salicornia- } \\
\text { veg.sed. }\end{array}$ & 86 & $17.2 \times 10^{6}$ & 4.824 & 1.442 & 3.382 & 21,232 & & \\
\hline Spartina-veg. & 117 & $2.34 \times 10^{6}$ & & & & & 2.95 & \\
\hline $\begin{array}{l}\text { Salicornia- } \\
\text { veg. }\end{array}$ & 86 & $1.72 \times 10^{6}$ & & & & & 1.41 & \\
\hline $\begin{array}{l}\text { Potential } \\
\text { export }^{2}\end{array}$ & & & & & & 400.6 & 4.36 & 405 \\
\hline \multicolumn{9}{|c|}{ Year 2055} \\
\hline $\begin{array}{l}\text { Sediment } \\
(0->5 \mathrm{~cm})\end{array}$ & 0 & & 0.108 & 0.087 & 0.021 & 0 & & \\
\hline $\begin{array}{l}\text { Spartina- } \\
\text { veg.sed. }\end{array}$ & 0 & & 4.824 & 1.442 & 3.382 & 0 & & \\
\hline $\begin{array}{l}\text { Salicornia- } \\
\text { veg.sed. }\end{array}$ & 203 & $40.6 \times 10^{6}$ & 4.824 & 1.442 & 3.382 & 50,118 & & \\
\hline Spartina-veg. & 0 & & & & & & 0 & \\
\hline $\begin{array}{l}\text { Salicornia- } \\
\text { veg. }\end{array}$ & 203 & $4.06 \times 10^{6}$ & & & & & 4.36 & \\
\hline $\begin{array}{l}\text { Potential } \\
\text { export }^{2}\end{array}$ & & & & & & 400.6 & 4.36 & 405 \\
\hline \multicolumn{9}{|c|}{$\begin{array}{l}{ }^{1} \text { Data from Table } 3-9 . \\
2 \text { Export from surficial sediments estimated at } 0.8 \% \text { of net } \mathrm{MeHg} \text { production per day. This estimate is derived as follows: the water- } \\
\text { exchangeable fraction of THg is } 0.35 \% \text { (Brannon et al. } 1980 \text { ). MeHg is slightly more water-soluble than THg, i.e. } 0.40 \% \text {. MeHg is } \\
\text { exposed two times per day to tidal waters. } \\
{ }^{3} \text { Assumed that all aboveground standing crop of } 1 \mathrm{~kg} \mathrm{DW} \mathrm{m}^{-2} \text { senesces per year, and } \mathrm{MeHg} \text { concentrations Table } 3-11 \text {. }\end{array}$} \\
\hline
\end{tabular}

Potential export of MeHg from restoration of whole target salt marsh area in San Pablo Bay. Large uncertainties in projections of $\mathrm{MeHg}$ export from HAAF will be multiplied when calculating total $\mathrm{MeHg}$ exports from all salt marshes bordering San Pablo Bay. In spite of these uncertainties, it is still useful to perform these calculations for the purpose of identifying key variables and initial attempts to delimit the solution space. Recommendations for salt marsh restoration in the San Pablo Bay (Goals Project 1999) include the restoration of salt marshes from a total area of 16,200 ha in 2005 to 42,525 ha in the future, while keeping an open water area in the bay of 102,870 ha intact. Net $\mathrm{MeHg}$ production rates of nonvegetated HAAF sediments are not an order of magnitude 
different from those measured by Marvin-DiPasquale et al. (2003) in open-water San Pablo Bay sediments (Table 3-14). With all else being equal, one would expect that a 42-percent increase in aerial surface area of wet estuarine sediment would result in a 42-percent increase in the production of MeHg in San Pablo Bay. In this context it is critically important to determine what part of the net $\mathrm{MeHg}$ production in bordering salt marshes is exported into San Pablo Bay in a manner that impacts the food web. If one chooses to assume that only 0.8 percent of the net $\mathrm{MeHg}$ production in the top 0 to $5 \mathrm{~cm}$ of sediment is exported to the bay with outflowing tides and all of the $\mathrm{MeHg}$ produced in the open bay sediments impacts the food web, then 42,525 ha of restored wetland would contribute only 2.6 percent of San Pablo Bay MeHg. This estimate does not include a trophic transfer link and is simplistic.

\begin{tabular}{|c|c|c|c|c|c|c|c|c|}
\hline \multicolumn{9}{|c|}{$\begin{array}{l}\text { Table 3-14 } \\
\text { Estimated Potential MeHg Production and Export from Tidal Marsh Areas in San Pablo } \\
\text { Bay }\end{array}$} \\
\hline Compartment & $\begin{array}{l}\text { Area, } \\
\text { ha }\end{array}$ & $\begin{array}{l}\text { Mass, } \\
\text { kg } \\
\text { DW/ha } \\
\end{array}$ & $\begin{array}{l}\text { Mass, } \\
\text { kg DW }\end{array}$ & \begin{tabular}{|l|} 
Net MeHg \\
Production \\
Rate, \\
$\mu \mathrm{g} / \mathrm{kg}$ DW/day \\
\end{tabular} & $\begin{array}{l}\text { Net MeHg } \\
\text { Production } \\
\text { Rate, } \\
\text { g/system/yr } \\
\end{array}$ & $\begin{array}{l}\text { MeHg Plant } \\
\text { Decomp. } \\
\text { Rate, } \\
\text { g/system/yr } \\
\end{array}$ & $\begin{array}{l}\text { Total MeHg } \\
\text { Potential } \\
\text { Export, } \\
\text { g/system/yr } \\
\end{array}$ & $\begin{array}{l}\text { Export/ } \\
\text { Production } \\
\text { Bay, } \\
\text { g/system/yr }\end{array}$ \\
\hline \multicolumn{9}{|c|}{ Year 2005} \\
\hline Bay & 102,870 & 200,000 & $20,574 \times 10^{6}$ & 0.155 & $1,162,472$ & & & \\
\hline $\begin{array}{l}\text { Tidal marsh } \\
\text { veg-sed. }{ }^{1}\end{array}$ & 16,200 & 200,000 & $3,240 \times 10^{6}$ & 1.166 & $1,379,266$ & & & \\
\hline $\begin{array}{l}\text { Tidal marsh- } \\
\text { veg. }{ }^{1}\end{array}$ & 16,200 & 20,000 & $324 \times 10^{6}$ & & & 348 & & \\
\hline $\begin{array}{l}\text { Tidal marsh } \\
\text { export }\end{array}$ & & & & & & & 11,382 & 0.010 \\
\hline Total Baylands & 119,070 & & & & & & & \\
\hline \multicolumn{9}{|c|}{ Target for Future } \\
\hline Bay & 102,870 & 200,000 & $20,574 \times 10^{6}$ & 0.155 & $1,162,472$ & & & \\
\hline $\begin{array}{l}\text { Tidal marsh } \\
\text { veg-sed. }{ }^{1}\end{array}$ & 42,525 & 200,000 & $8,505 \times 10^{6}$ & 1.166 & $3,620,574$ & & & \\
\hline $\begin{array}{l}\text { Tidal marsh- } \\
\text { veg. }{ }^{1}\end{array}$ & 42,525 & 20,000 & $850.5 \times 10^{6}$ & & & 913 & & \\
\hline $\begin{array}{l}\text { Tidal marsh } \\
\text { export }^{1}\end{array}$ & & & & & & & 29,878 & 0.026 \\
\hline Total Baylands & 145,395 & & & & & & & \\
\hline
\end{tabular}

In this context comprehensive information on the spatial sedimentary distribution of net $\mathrm{MeHg}$ rates in San Pablo Bay is needed. The impact on the trophic system of 1 mole of $\mathrm{MeHg}$ produced in open-water sediment relative to 1 mole produced in a bordering salt marsh must be determined. This will require analysis of volatilization of mercury from wetlands because it has been shown to be a major route of export from other wetland systems (Lindberg et al. 2002). 


\section{Spatial Distribution and Concentrations of Mercury Species in the Vegetated Marsh Zones ${ }^{1}$}

\section{Summary}

The purpose of this study was to determine a tentative relationship between marsh zones and THg and MeHg levels in the sediments, and assess the THg and $\mathrm{MeHg}$ concentrations in live and dead plant materials collected from these zones.

For this, a tentative relationship between marsh zonation and $\mathrm{THg}$ or $\mathrm{MeHg}$ concentrations in the sediment was explored by regrouping previously collected data on $\mathrm{Hg}$ species concentrations in surficial sediment cores according to vegetation zone, and calculating mean values for each zone. Furthermore, tissues from live plant shoots and from plant detritus were collected from as many zones as possible, and analyzed for mercury species. The following zones were distinguished: nonvegetated mudflats, $S$. foliosa-vegetated tidal marsh, $S$. virginica-vegetated upper marsh, and upland-seasonally flooded wetland.

The THg and MeHg levels in the surficial sediments of the marsh zones varied by zone. The mean THg concentrations in the surface sediments decreased in the order Low marsh $>$ High marsh $>$ Diked high marsh $>$ Mudflat. No distinct effect of dry and wet season on THg concentration was noted. Mean THg concentrations in the dry season were: Low marsh $346 \mathrm{ng} \mathrm{g}^{-1} \mathrm{DW}$, High marsh $292 \mathrm{ng} \mathrm{g}^{-1}$ DW, Diked high marsh $261 \mathrm{ng} \mathrm{g}^{-1} \mathrm{DW}$, Mudflat $236 \mathrm{ng} \mathrm{g}^{-1} \mathrm{DW}$.

Mean $\mathrm{MeHg}$ concentrations increased in the sediments of all zones during the wet season except in the mudflats. Mean $\mathrm{MeHg}$ concentrations decreased in the order High marsh $7.29 \mathrm{ng} \mathrm{g}^{-1} \mathrm{DW}>$ Low marsh $5.17 \mathrm{ng} \mathrm{g}^{-1} \mathrm{DW}>$ Diked high marsh $1.82 \mathrm{ng} \mathrm{g}^{-1} \mathrm{DW}>$ Mudflat $0.73 \mathrm{ng} \mathrm{g}^{-1} \mathrm{DW}$.

\footnotetext{
${ }^{1}$ Point of contact for this chapter is Richard A. Price, U.S. Army Engineer Research and Development Center, Environmental Laboratory, Vicksburg, Mississippi, USA,

Ph:601-634-3636; Email: richard.a.price@erdc.usace.army.mil
} 
In plant shoots, the mean concentrations of THg ranged from 14 to $25 \mathrm{ng} \mathrm{g}^{-1}$ $\mathrm{DW}$, and of $\mathrm{MeHg}$ from 0.17 to $0.96 \mathrm{ng} \mathrm{g}^{-1} \mathrm{DW}$ in $S$. foliosa and S. virginica. $\mathrm{THg}$ and $\mathrm{MeHg}$ levels in the plant shoots did not appear to be related to species or zone, but the number of locations sampled was small. The THg and $\mathrm{MeHg}$ levels in plant detritus were far higher than in live shoots, i.e., by a factor of 5 to 8 .

\section{Introduction}

Methylmercury $(\mathrm{MeHg})$ is a concern in many wetland and aquatic systems. A field survey of existing wetlands in the San Francisco Bay/Estuary system (Lee et al. 2000) found Hg accumulation in Spartina foliosa, Salicornia virginica, and other plant species in marine, estuarine, and freshwater wetlands, suggesting that plants play a role in the cycling of $\mathrm{Hg}$ in wetlands. Recent studies on the relationships between microbial assemblages and their interactions with saltmarsh plants have shown that $\mathrm{MeHg}$ concentrations in the rhizosphere of Spartina alterniflora can be lower than in the ambient sediments (King et al. 2001). In another recent study on $\mathrm{Hg}$ and $\mathrm{MeHg}$ cycling in freshwater floodplain margins, low $\mathrm{MeHg}$ concentrations $\left(<0.5 \mathrm{ng} \mathrm{g}^{-1}\right.$, i.e., $<1$ percent $\left.\mathrm{THg}\right)$ were found in lake sediments, but far higher concentrations were found in the humic layer covering the sediments of the lake margins (Roulet et al. 2001). Maximum $\mathrm{MeHg}$ concentrations of 3 to $8 \mathrm{ng} \mathrm{g}^{-1}$, or 2 to 5 percent of $\mathrm{THg}$, occurred in the litter and organic layers of the inundated forest soils. On the basis of these results, it was suggested that $\mathrm{MeHg}$ concentrations increase with organic carbon concentration. In a study on the effects of forest canopy on $\mathrm{THg}$ and $\mathrm{MeHg}$ fluxes in upland and wetland ecosystems in Ontario, Canada, the flux of $\mathrm{THg}$ and $\mathrm{MeHg}$ with litterfall was found to be substantial compared to throughfall and direct wet deposition, and it was suggested that the $\mathrm{Hg}$ in litterfall was derived from uptake from soil or directly by foliage (St. Louis et al. 2001).

The impacts of marsh plant communities on the production of $\mathrm{MeHg}$ in their rhizospheres, and the roles of these plant communities in the cycling of THg and $\mathrm{MeHg}$ in the marsh have to be quantified to serve as a basis for a management plan aimed at minimizing $\mathrm{MeHg}$ production in the wetland system.

\section{Purpose}

The purpose of this study was to determine a tentative relationship between marsh zones, nonvegetated and vegetated, by dominant plant communities of salt marshes bordering the Hamilton Army Airfield (HAAF) Wetland Restoration Site (WRS) and $\mathrm{THg}$ and $\mathrm{MeHg}$ levels in the sediments, and assess the THg and $\mathrm{MeHg}$ concentrations in live and dead plant materials collected from these zones.

For this, a tentative relationship between marsh zonation and $\mathrm{THg}$ or $\mathrm{MeHg}$ concentrations in the sediment was explored by regrouping previously collected data on $\mathrm{Hg}$ species concentrations in surficial sediment cores according to vegetation zone, and calculating mean values for each zone. Furthermore, tissues from live plant shoots and from plant detritus were collected from as many zones as 
possible, and analyzed for mercury species. The following zones were distinguished: nonvegetated mudflats, $S$. foliosa-vegetated tidal marsh, $S$. virginica-vegetated upper marsh, and upland-seasonally flooded wetland.

\section{Methods and Materials}

\section{Regrouping of previously collected sediment core data}

Previously collected data on $\mathrm{THg}$ and $\mathrm{MeHg}$ concentrations in surficial sediment cores (McFarland et al. 2002; McFarland et al. 2003a) were regrouped according to the vegetation zones distinguished for the entire study, and mean values for each zone were calculated, to explore a tentative relationship between marsh zone and $\mathrm{THg}$ or $\mathrm{MeHg}$ concentration in the sediment. For this regrouping, the following zones were distinguished: Nonvegetated mudflats, S. foliosavegetated tidal marsh, $S$. virginica-vegetated upper marsh, and upland-seasonally flooded wetland.

\section{Site selection for plant material collection}

Tissues from live plant shoots and from plant detritus were collected from as many zones as possible, and analyzed for $\mathrm{Hg}$ species. Sample sites were chosen to match selected sites at which sediments had been collected in September 2001 (McFarland et al. 2002) and that were vegetated by representative higher plant communities. Photographs of sampling activities were reviewed to provide additional information in some cases. The plant samples were collected in June 2003. Sample station coordinates, provided in McFarland et al. (2002), were located using a global positioning unit, and plant communities and other station characteristics were noted. The tidal marshes around the San Francisco Bay are dominated by the native Spartina foliosa (Pacific cordgrass) and Salicornia virginica (common pickleweed; for description of vegetation zones, see Chapter 3 of this report).

\section{Plant tissue collection}

Plant tissue samples were collected from five locations (Table 4-1). Three locations were situated in the HAAF, one in the Bel Marin, and one in the China Camp wetland. At all locations shoot material of the dominant plant species was sampled, and at two locations detritus was also collected. The aboveground portion of each plant was cut approximately $5 \mathrm{~cm}$ above the soil surface with stainless steel shears. The cut tissue was immediately placed in Ziplock bags and stored in a cooler with dry ice. At the conclusion of the sampling day, the tissues were removed from the Ziploc bags and rinsed in distilled water to remove any dust or soil particles. The rinsed tissues were placed on paper towels to quickly remove excess water and then vacuum-sealed in heavy-duty polyethylene bags. Each bag was labeled, placed back in the cooler and flash frozen with sufficient dry ice. Samples were shipped frozen to the ERDC where they were logged and placed in a freezer for continued preservation. 


\begin{tabular}{|c|c|c|c|}
\hline \multicolumn{4}{|c|}{$\begin{array}{l}\text { Table 4-1 } \\
\text { Sample Stations in Vegetation Zones }\end{array}$} \\
\hline Site/Vegetation zone & HAAF & Bel Marin & China Camp \\
\hline Low marsh & $\begin{array}{l}\text { SM-10 } \\
\text { Lat } 38^{\circ} 03.116 \\
\text { Long } 122^{\circ} 29.550 \\
\text { (S. foliosa shoots) }\end{array}$ & & $\begin{array}{l}\text { R-44 } \\
\text { Lat } 38^{\circ} 00.411 \\
\text { Long } 122^{\circ} 28.758 \\
\text { (S. foliosa shoots) } \\
\text { (Scirpus maritimus shoots) }\end{array}$ \\
\hline \multirow[t]{2}{*}{ High marsh } & $\begin{array}{l}\text { SM-11 } \\
\text { Lat } 38^{\circ} 03.135 \\
\text { Long } 122^{\circ} 29.637 \\
\text { (S. virginica shoots) }\end{array}$ & & (S. virginica shoots) \\
\hline & $\begin{array}{l}\text { SM-12 } \\
\text { Lat } 38^{\circ} 03.139 \\
\text { Long } 122^{\circ} 29.723 \\
\text { (S. virginica shoots) } \\
\text { (Detritus) }\end{array}$ & & \\
\hline Diked high marsh & & \begin{tabular}{|l} 
BM-50 \\
Lat $38^{\circ} 04.399$ \\
Long $122^{\circ} 29.085$ \\
(S. virginica) \\
(Detritus)
\end{tabular} & \\
\hline
\end{tabular}

\section{Analysis of plant tissues for total and methylmercury}

THg. USEPA method 7421 was used (USEPA 1992c). The plant samples were thoroughly ground in a stainless steel mixer prior to the dissolution process. Approximately a $0.2-\mathrm{g}$ sample of the plant tissue was heated at $115^{\circ} \mathrm{C}$ with sulfuric acid and nitric acid for $1 \mathrm{hr}$ or until the tissue dissolved. Subsequently, $50 \mathrm{~mL}$ of water was carefully added to the acidic mixture followed by an excess of potassium permanganate. This mixture was heated at $95^{\circ} \mathrm{C}$ for $1 \mathrm{hr}$. The excess potassium permanganate was reduced with hydroxylamine hydrochloride and sodium chloride solution. Mercury was determined using a CETAC M-6000A Atomic Absorption Mercury Analyzer. Typical reporting and method detection limits for this sample size are 0.025 and $0.005 \mathrm{ng} \mathrm{g}^{-1}$, respectively.

MeHg. Methods were modified after Bloom (1989), Horvat et al. (1993), Hammerschmidt and Fitzgerald (2001), and St.Louis et al. (2001). The plant material was blended using a stainless steel mixer. Approximately $0.2 \mathrm{~g}$ of blended plant tissue was extracted and distilled from Teflon distillation vessels using a mix of $\mathrm{H}_{2} \mathrm{SO}_{4}, \mathrm{KC} 1, \mathrm{H}_{2} \mathrm{O}$ and $\mathrm{CuSO}_{4}$ as the extracting and distillation solution. Samples were distilled in a $130{ }^{\circ} \mathrm{C}$ carbon block, assisted by a stream of nitrogen, until about 80 percent of the solution was collected in Teflon receiver bottles held just above freezing in a specially designed refrigerator. All of the connecting transfer lines for the distillation apparatus are Teflon. Then 0.5 $\mathrm{mL}$ of $2 \mathrm{M}$ acetate buffer was added to each sample, including standards and quality control samples, after the distillates were transferred to Erlenmeyer flask reaction vessels. After that, $0.1 \mathrm{~mL}$ of 1-percent sodium tetraethyl borate was added to the reaction vessels and the ethylation process was allowed to proceed for $15 \mathrm{~min}$. At the end of the reaction period, volatile $\mathrm{Hg}$ compounds were purged from the reaction solution with nitrogen gas and the $\mathrm{Hg}$ compounds were collected on activated carbon column traps. The Hg compounds were purged 
from the activated carbon traps at $360^{\circ} \mathrm{C}$ and allowed to pass through a gas chromatograph with an OV-3 column held isothermal at $100^{\circ} \mathrm{C}$. The effluent $\mathrm{Hg}$ compounds were pyrolyzed in a quartz column with quartz wool at approximately $800{ }^{\circ} \mathrm{C}$ and the resulting $\mathrm{Hg}$ detected with cold-vapor atomic fluorescence spectroscopy. The typical reporting limit for this sample size is 0.05 $n g \mathrm{~g}^{-1}$.

\section{Results and Discussion}

\section{$\mathrm{THg}$ and $\mathrm{MeHg}$ concentrations in nonvegetated and vegetated sediments}

Mean $\mathrm{THg}$ concentrations in the surface sediments decreased in the order Low marsh $>$ High marsh $>$ Diked high marsh $>$ Mudflat (Figure 4-1, Table 4-2). No distinct effect of dry and wet season on $\mathrm{THg}$ concentration was noted. Mean $\mathrm{THg}$ concentrations in the dry season were: Low marsh $346 \mathrm{ng} \mathrm{g}^{-1} \mathrm{DW}$, High marsh $292 \mathrm{ng} \mathrm{g}^{-1}$ DW, Diked high marsh $261 \mathrm{ng} \mathrm{g}^{-1}$ DW, Mudflat $236 \mathrm{ng} \mathrm{g}^{-1} \mathrm{DW}$.

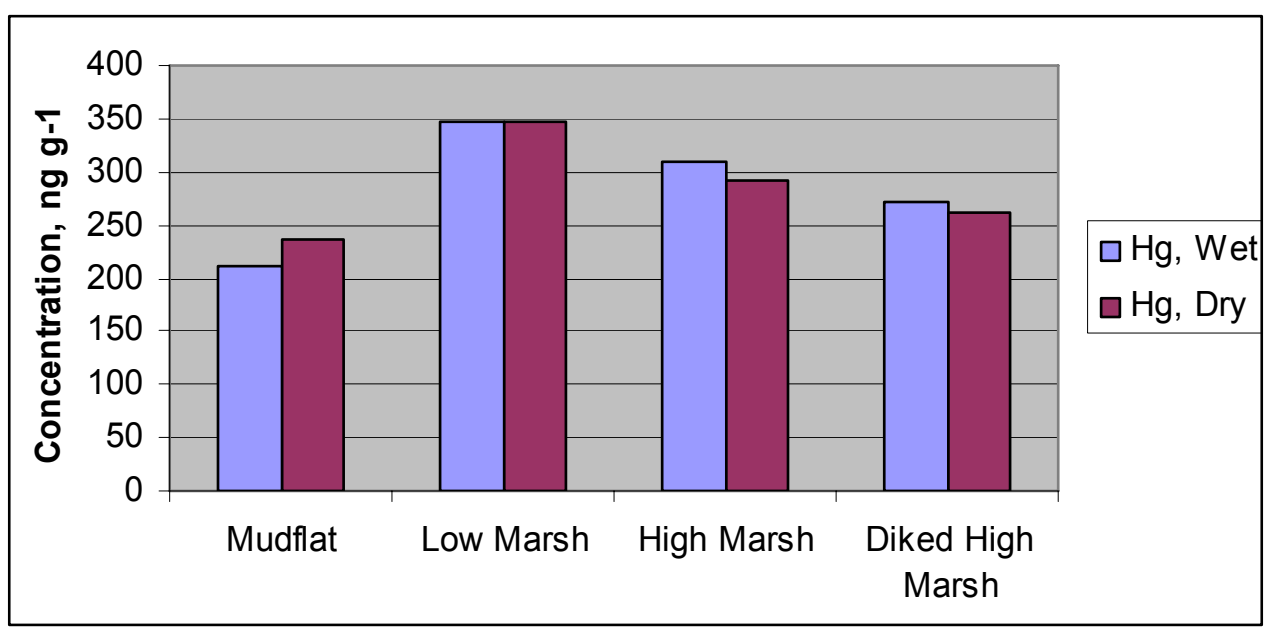

Figure 4-1. Total sediment $\mathrm{Hg}$ by vegetation zone

Mean $\mathrm{MeHg}$ concentrations increased in the surface sediments of all zones during the wet season except in the mudflats (Figure 4-2, Table 4-2). MeHg concentrations increased 449 percent in the upper marsh dominated by $S$. virginica, followed by the tidal zone dominated by S. foliosa (133 percent), upland zone (68.9 percent), and mudflat (-34.2 percent). Mean $\mathrm{MeHg}$ concentrations decreased in the order High marsh $7.29 \mathrm{ng} \mathrm{g}^{-1} \mathrm{DW}>$ Low marsh $5.17 \mathrm{ng} \mathrm{g}^{-1} \mathrm{DW}>$ Diked high marsh $1.82 \mathrm{ng} \mathrm{g}^{-1} \mathrm{DW}>$ Mudflat $0.73 \mathrm{ng} \mathrm{g}^{-1} \mathrm{DW}$. High $\mathrm{MeHg}$ concentrations were found in the sediment of stations AF-36, AF-37, and BM-50. These sites were very dry in the dry season, but were covered by standing water and plant detritus during the wet season. Some of these conditions also occurred in the upper marsh in the wet season and in other areas in the dry season. 


\begin{tabular}{|c|c|c|c|c|c|c|c|c|}
\hline \multicolumn{9}{|c|}{$\begin{array}{l}\text { Table 4-2 } \\
\text { THg and MeHg Characteristics in Upper } 2 \mathrm{~cm} \text { of Sediment in HAAF and China Camp } \\
\text { (from McFarland et al. (2002)) }\end{array}$} \\
\hline \multirow[b]{2}{*}{ Zone/THg and $\mathrm{MeHg}$} & \multicolumn{2}{|c|}{ Mudflat } & \multicolumn{2}{|c|}{ Low Marsh } & \multicolumn{2}{|c|}{ High Marsh } & \multicolumn{2}{|c|}{$\begin{array}{l}\text { Diked High } \\
\text { Marsh }\end{array}$} \\
\hline & Dry & Wet & Dry & Wet & Dry & Wet & Dry & Wet \\
\hline Mean $\mathrm{Hg}$, in $\mathrm{ng} \mathrm{g}^{-1} \mathrm{DW}(\mathrm{SD})$ & $\begin{array}{l}236 \\
(231.5)\end{array}$ & $\begin{array}{l}210.4 \\
(200.4)\end{array}$ & $\begin{array}{l}346 \\
(100.6)\end{array}$ & $\begin{array}{l}348 \\
(92.4)\end{array}$ & $\begin{array}{l}292 \\
(75.6)\end{array}$ & $\begin{array}{l}309 \\
(122.8)\end{array}$ & $\begin{array}{l}260.5 \\
(78.8)\end{array}$ & $\begin{array}{l}272 \\
(73.4)\end{array}$ \\
\hline Maximum $\mathrm{Hg}$, in $\mathrm{ng} \mathrm{g}^{-1} \mathrm{DW}$ & 600 & 495 & 740 & 611 & 710 & 900 & 450 & 412 \\
\hline Minimum $\mathrm{Hg}$, in $\mathrm{ng} \mathrm{g}^{-1} \mathrm{DW}$ & 40 & 63.5 & 100 & 141 & 180 & 88.5 & 30 & 43 \\
\hline Mean $\mathrm{MeHg}$, in $\mathrm{mg} \mathrm{kg}^{-1} \mathrm{DW}(\mathrm{SD})$ & $\begin{array}{ll}1.11 \\
(1.33)\end{array}$ & $\begin{array}{l}0.731 \\
(0.879)\end{array}$ & $\begin{array}{l}2.21 \\
(2.99)\end{array}$ & $\begin{array}{l}5.17 \\
(10.07)\end{array}$ & $\begin{array}{l}1.33 \\
(1.8)\end{array}$ & $\begin{array}{l}7.29 \\
(7.23)\end{array}$ & $\begin{array}{l}1.08 \\
(1.61)\end{array}$ & $\begin{array}{l}1.82 \\
(2.95)\end{array}$ \\
\hline Maximum $\mathrm{MeHg}$, in $\mathrm{ng} \mathrm{g}^{-1} \mathrm{DW}$ & 4.6 & 2.56 & 15 & 74.7 & 8.1 & 38.9 & 8.5 & 16.3 \\
\hline Minimum $\mathrm{MeHg}$, in $\mathrm{ng} \mathrm{g}^{-1} \mathrm{DW}$ & 0.05 & 0.018 & 0.05 & 0.34 & 0.05 & 0.05 & 0.033 & 0.03 \\
\hline $\mathrm{MeHg}$, in \% $\mathrm{THg}$ & 0.471 & 0.347 & 0.64 & 1.48 & 0.454 & 2.36 & 0.41 & 0.67 \\
\hline $\begin{array}{l}\text { MeHg wet season increase, in \% dry } \\
\text { season }\end{array}$ & NA & -34.20 & & 133 & & 449 & & 68.90 \\
\hline
\end{tabular}

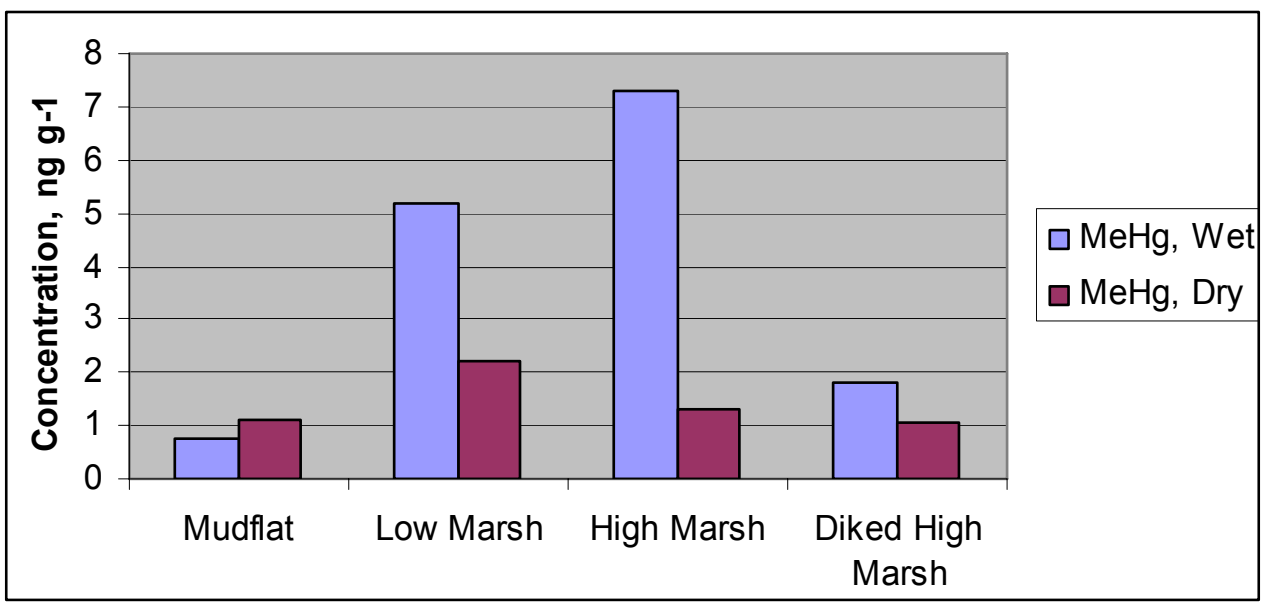

Figure 4-2. Sediment MeHg by vegetation zone

\section{$\mathrm{THg}$ and MeHg concentrations in plant tissues}

The mean THg concentrations ranged from 14 to $25 \mathrm{ng} \mathrm{g}^{-1} \mathrm{DW}$ in the shoots of $S$. foliosa and $S$. virginica (Table 4-3). The mean $\mathrm{MeHg}$ concentrations ranged from 0.17 to $0.96 \mathrm{ng} \mathrm{g}^{-1} \mathrm{DW}$ in plant shoots. The THg concentrations in the shoots were in the same order of magnitude of those reported in Chapter 3 of this report. However, the $\mathrm{MeHg}$ concentrations were far lower than reported in Chapter 3; i.e., they amounted to only about half of the values measured using an alternative analytical method. This underestimate in the current case may be due to problems encountered in analyzing the green plant tissues, where the fluorescence of the plant chlorophylls interfered with the fluorescence of the $\mathrm{Hg}$. 


\begin{tabular}{|c|c|c|c|c|c|c|}
\hline \multicolumn{7}{|c|}{$\begin{array}{l}\text { Table 4-3 } \\
\text { THg and MeHg Characteristics in Plant Tissues and Detritus from HAAF, Bel Marin, anc } \\
\text { China Camp }\end{array}$} \\
\hline \multirow[b]{2}{*}{ Site/Vegetation Zone } & \multicolumn{2}{|c|}{ HAAF } & \multicolumn{2}{|c|}{ Bel Marin } & \multicolumn{2}{|c|}{ China Camp } \\
\hline & \begin{tabular}{|l|} 
THg, \\
ng g $^{-1} \mathrm{DW}$ \\
\end{tabular} & \begin{tabular}{|l|}
$\mathrm{MeHg}^{-1}$ \\
$\mathrm{ng} \mathrm{g}^{-1} \mathrm{~W}$
\end{tabular} & \begin{tabular}{|l|}
$\mathrm{THg}$, \\
$\mathrm{ng} \mathrm{g}^{-1} \mathrm{DW}$
\end{tabular} & \begin{tabular}{|l|} 
MeHg $^{-1}$ DW \\
\end{tabular} & \begin{tabular}{|l|} 
THg, \\
ng g $^{-1} \mathrm{DW}$
\end{tabular} & \begin{tabular}{|l}
$\mathrm{MeHg}$ \\
$\mathrm{ng} \mathrm{g}^{-1} \mathrm{DW}$
\end{tabular} \\
\hline Low marsh & SM-10 & & & & R-44 & \\
\hline S. foliosa shoots & $16(3)$ & $0.17(0.05)$ & & & $14(3)$ & $0.41(0.16)$ \\
\hline S. maritimus shoots & & & & & $16(1)$ & $0.23(0.07)$ \\
\hline S. virginica shoots & & & & & $25(2)$ & $0.37(0.09)$ \\
\hline High marsh & SM-11 & & & & & \\
\hline \multirow[t]{2}{*}{ S. virginica shoots } & $23(5)$ & $0.49(0.18)$ & & & & \\
\hline & SM-12 & & & & & \\
\hline S. virginica shoots & $28(7)$ & $0.96(0.34)$ & & & & \\
\hline Detritus & $236(49)$ & $7.04(3.19)$ & & & & \\
\hline Diked high marsh & & & BM-50 & & & \\
\hline S. virginica shoots & & & $25(5)$ & $1.33(0.34)$ & & \\
\hline Detritus & & & $114(20)$ & $16.32(3.59)$ & & \\
\hline
\end{tabular}

Both the THg and $\mathrm{MeHg}$ concentrations in detritus greatly exceeded those in the plant shoots by a factor of 5 to 8 (Table 4-3). The concentrations of THg ranged from $236 \mathrm{ng} \mathrm{g}^{-1} \mathrm{DW}$ on the high marsh to $114 \mathrm{ng} \mathrm{g}^{-1} \mathrm{DW}$ in the diked marsh, and the concentrations of $\mathrm{MeHg}$ ranged from $7.04 \mathrm{ng} \mathrm{g}^{-1} \mathrm{DW}$ on the high marsh to $16.32 \mathrm{ng} \mathrm{g}^{-1} \mathrm{DW}$ on the diked marsh. 


\section{Geochemical Characterization of HAAF Sediment Profiles and Mercury Species Levels in Macrofauna $^{1,2}$}

\section{Summary}

This chapter details the results of a field study conducted in June 2003. The purpose of this effort was to measure total mercury $(\mathrm{THg})$ and methylmercury $(\mathrm{MeHg})$ levels in the sediment in relation to depth at intertidal sites at Hamilton Army Airfield (HAAF) and China Camp State Park (as a reference), as well as inland sites at HAAF and Bel Marin Creek. Other parameters important for the cycling of $\mathrm{Hg}$ and $\mathrm{MeHg}$ in sediments were also determined with the goal of establishing site-specific relationships between these parameters and $\mathrm{THg}$ and $\mathrm{MeHg}$. Finally, $\mathrm{Hg}$ and $\mathrm{MeHg}$ were measured in macrofauna collected at the above-mentioned intertidal sites for the purpose of calculating site-specific biotasediment bioaccumulation factors (BAFs).

For sediments, the highest $\mathrm{MeHg}$ concentrations were found in the upper 2.5 to $5.1 \mathrm{~cm}$ of the cores, and levels decreased with depth suggesting that conditions for the methylation of $\mathrm{Hg}$ are most favorable near the surface. THg levels increased with depth, correlating inversely with $\mathrm{MeHg}$. The significance of this is unclear, but may suggest a net loss of mercury from the surface through volatilization or surface runoff/tidal transport of $\mathrm{MeHg}$ from the sediment surface. $\mathrm{MeHg}$ correlated directly with redox potential $\left(\mathrm{E}_{\mathrm{h}}\right)$, total organic carbon (TOC), and phosphorus $(\mathrm{P})$, suggesting that these parameters were associated with $\mathrm{MeHg}$ levels in HAAF marsh sediment. The predicted influence of $\mathrm{E}_{\mathrm{h}}$ and $\mathrm{pH}$ on the bioavailability of $\mathrm{Hg}$ is consistent with the observed $\mathrm{MeHg}$ profile with more positive $\mathrm{E}_{\mathrm{h}}$ values representing oxic conditions near the surface favoring $\mathrm{Hg}$ in

\footnotetext{
${ }^{1}$ Point of contact for this chapter is Robert P. Jones, U.S. Army Engineer Research and Development Center, Environmental Laboratory, Vicksburg, Mississippi, USA, Phone: 601-634-4098, Email: robert.p.jones@erdc.usace.army.mil.

${ }^{2}$ Supporting documentation for this chapter can be found in Appendix A.
} 
the bioavailable $\mathrm{Hg}^{0}$ state, and more negative $\mathrm{E}_{\mathrm{h}}$ values (anoxic) at increasing depths favoring formation of non-bioavailable $\mathrm{HgS}$.

For macrofauna, significant levels of $\mathrm{THg}$ and $\mathrm{MeHg}$ were detected in tissues of animals collected at intertidal sites at HAAF and China Camp, suggesting that both $\mathrm{THg}$ and $\mathrm{MeHg}$ are available for uptake. $\mathrm{MeHg}$ comprised on average 40 percent of $\mathrm{THg}$ (range 20 percent to 70 percent), indicating that a significant portion of the invertebrate $\mathrm{THg}$ body burden is in the form of $\mathrm{MeHg}$. Calculated BAFs (greater than 1) suggest that $\mathrm{MeHg}$ has a strong tendency toward bioaccumulation, and BAFs for MeHg ranged from about 3 to 50. Snails were the highest $\mathrm{Hg}$ bioaccumulators. Because the diet of these animals is composed largely of plant material, it is likely that $\mathrm{MeHg}$ in plants represents an important $\mathrm{MeHg}$ source for terrestrial trophic transfer.

\section{Introduction}

During the peak of the dry and wet seasons of 2002-2003, the surficial soils and sediments on the periphery of the HAAF Wetland Restoration site and at a nearby reference tidal salt marsh (China Camp) were sampled and analyzed for THg and MeHg (McFarland et al. 2002; McFarland et al. 2003a). THg surficial concentrations averaged $0.3 \mathrm{ng} \mathrm{g}^{-1}$ dry weight overall in both seasons and $\mathrm{MeHg}$ averaged 1.5 and $4.4 \mathrm{ng} \mathrm{g}^{-1}$ dry weight, dry and wet seasons, respectively. $\mathrm{MeHg}$ concentrations were highly variable in both seasons with sporadic occurrence of high outliers. Concentration distributions were strongly skewed toward the low end with median concentrations of $\mathrm{MeHg}$ equal to 0.6 and $1.9 \mathrm{ng} \mathrm{g}^{-1}$ dry weight (dry season, wet season) and with highest concentrations ranging to more than $20 \mathrm{ng} \mathrm{g}^{-1}$ dry weight in the wet season. $\mathrm{MeHg}$ concentration distributions at the western North Bay sites can be characterized as being typically on the order of 1 to $2 \mathrm{ng} \mathrm{g}^{-1}$ dry weight, but with infrequent tenfold greater spikes, and overall about threefold higher in the wet than in the dry season.

Increased $\mathrm{MeHg}$ concentrations were most pronounced in the area identified as "High Marsh" (i.e., McFarland et al. 2002). Samples at this location were taken close to the levee on the bay side of the former airfield. The uppermost reaches of the tertiary channels are in this location. Channel bottoms cut to depths of up to $1 \mathrm{~m}$ through this part of the marsh. The flora in this area is predominated by pickleweed, interspersed with grasses. The area is above Mean High Water (MHW) and receives relatively more fresh water from storm runoff than salt water from tidal flux. There is little visible difference between the High and Mid-Marsh locations. High MeHg spikes were also found in the Mid-Marsh sampled in the wet season. Background information on tidal marsh structure and function is provided in Chapter 3 of this report.

\section{Purpose}

In 2003, a field study was conducted to: 
a. Measure total $\mathrm{Hg}$ and $\mathrm{MeHg}$ levels in the sediment in relation to depth at three intertidal sites at HAAF, one inland site at HAAF, one intertidal site at China Camp, and one site at the Bel Marin Creek.

b. Determine other parameters important for the cycling of $\mathrm{Hg}$ and $\mathrm{MeHg}$ in sediments.

c. Determine $\mathrm{Hg}$ and $\mathrm{MeHg}$ bioaccumulated in macrofauna.

\section{Site Selection for the Collection of Sediment Cores and Macrofauna Specimens}

Five sites were selected for core sampling and analysis by depth section. THg and $\mathrm{MeHg}$ analyses of the wet season samples were not available for review before selection of the core sample sites, so knowledge of the areas showing highest seasonally affected potential for $\mathrm{Hg}$ methylation could not be used for this purpose. Instead, the sites were chosen based on results of the dry season analyses and on previous field studies of $\mathrm{THg}$ and $\mathrm{MeHg}$ levels in estuaries (Bartlett and Craig 1981a, Kannan et al. 1998). Selection of two intertidal sites at the HAAF Bay Edge location (SM-1 and SM-10) and a similar site at China Camp (R-44) was influenced by the relative abundance there of invertebrate biota at previous sample times. The highest $\mathrm{THg}$ concentrations were found at the HAAF Bay Edge sites, and rates of methylation were expected to be high at these sites because the redox cline was close to the surface. One sample site was selected at the Bel Marin Creek location (BM-50a) representing the lowest expected level of $\mathrm{Hg}$ contamination based on earlier studies. An additional site was sampled inland from the SM-10 location (designated SM-10U) in less wetted soil/sediment and provided the deepest core obtainable with the collecting equipment used. Macrofauna (mussels, crabs, and snails) were collected at SM-1, SM-10, and R-44 to determine $\mathrm{THg}$ and $\mathrm{MeHg}$ bioaccumulation. All samples were collected during the week of June 9-12, 2003. Stations were located using GPS and marked with stakes. The marked positions were used as reference points for the activities of all members of the research team in order to maximize comparability of results. Locations and brief descriptions are given in Table 5-1.

\section{Methods}

\section{Sediment sampling}

Five replicate samples were taken at site SM-1 within a rectangular zone extending approximately $3 \mathrm{~m}$ along the shoreline and approximately $2 \mathrm{~m}$ in width above the water's edge. At each of the five replicate sampling points (SM-1-1 through SM-1-5), 4-6 cores were collected within an area of approximately $1 \mathrm{~m}^{2}$. Site SM-10 was sampled similarly to site SM-1. Sample SM-10U was collected approximately $30 \mathrm{~m}$ inland. No replicates were taken at SM-10U, and a modified sampling procedure was employed. One sample was taken at the Bel Marin Creek location (BM-50a) in a rectangular zone approximately $1 \mathrm{~m}$ in length along the edge of the channel and approximately $0.3 \mathrm{~m}$ in width from the water's 
edge inland. Four cores were collected. The China Camp site (R-44) was sampled similarly to the HAAF Bay Edge locations.

\begin{tabular}{|c|c|c|c|}
\hline \multicolumn{4}{|c|}{$\begin{array}{l}\text { Table 5-1 } \\
\text { Sample Stations in Vegetation Zones }\end{array}$} \\
\hline $\begin{array}{l}\text { Site/Vegetation } \\
\text { Zone }\end{array}$ & HAAF & Bel Marin & China Camp \\
\hline \multirow[t]{2}{*}{ Low marsh } & $\begin{array}{l}\text { SM-1 } \\
\text { Lat. (N) } 38^{\circ} 02.904 \\
\text { Long. (W) } 122^{\circ} 29.613 \\
\text { (S. foliosa dominated) }\end{array}$ & & $\begin{array}{l}\text { R-44 } \\
\text { Lat. (N) } 38^{\circ} 00.411 \\
\text { Long. (W) } 122^{\circ} 28.758 \\
\text { (S. foliosa transitioning into } \\
\text { S. virginica) }\end{array}$ \\
\hline & $\begin{array}{l}\text { SM-10 } \\
\text { Lat. (N) } 38^{\circ} 03.116 \\
\text { Long. (W) } 122^{\circ} 29.550 \\
\text { (S. foliosa dominated) }\end{array}$ & & \\
\hline Mid marsh & $\begin{array}{l}\text { SM-10U } \\
\text { Lat./Long. Not measured } \\
\text { (10 m inland from SM-10) } \\
\text { (S. virginica dominated with abundant } \\
\text { detritus) }\end{array}$ & & \\
\hline Diked high marsh & & $\begin{array}{l}\text { BM-50a } \\
\text { Lat. (N) } 38^{\circ} 03.116 \\
\text { Long. (W) } 122^{\circ} 29.550 \\
\text { (pump station creek } \\
\text { edge) } \\
\text { (S. virginica dominated) }\end{array}$ & \\
\hline
\end{tabular}

\section{Core sampling procedure}

At each site, samples were collected with a stainless steel, 5-cm-diam by $30-\mathrm{cm}$ core-sampling device. Clear plastic liners (with plastic eggshells at the bottom to prevent loss of the core when extracting the sampler from the ground) were inserted into the sampling device. A stainless steel head was attached to hold the liner and eggshell in place during the sampling process. The sampler was pushed into the sediment until the top was even with the sediment surface. The core was extracted by slowly withdrawing the sampler with the aid of a T-shaped handle on the top of the sampler. Cores collected in this manner typically measured 15 to $20 \mathrm{~cm}$ in length. The sampling procedure for SM-10U was modified to obtain a deeper core. The sampler configuration described above was employed. However, after extracting a single core from this sampling point, a second core was collected by reinserting the sampler into the hole created by removal of the first sample. In this manner, a depth profile of approximately 40 $\mathrm{cm}$ was achieved. The core liner containing the sample was immediately removed from the sampling device, labeled, capped, and frozen in a cooler with dry ice. Coolers were held overnight, repacked with dry ice as needed, and shipped via overnight express to the ERDC Vicksburg Environmental Chemistry Laboratory. All samples were received frozen and were stored frozen at $-21^{\circ} \mathrm{C}$ until further processing. 


\section{Field measurement of core redox potential and $\mathrm{pH}$}

At each replicate site, a field depth profile for soil core oxidation/reduction potential (redox; $\mathrm{E}_{\mathrm{h}}$ ) and $\mathrm{pH}$ was performed. Modified core liners were fashioned with 1-cm-diam holes to allow an $\mathrm{E}_{\mathrm{h}}$ or $\mathrm{pH}$ probe (SympHony probes, VWR International, West Chester, PA) to be inserted into freshly collected core samples. The core to be profiled was collected using one of these liners. The liner with core in place was then removed from the sampler and placed horizontally on a paper towel on the ground. Multiple probes were simultaneously pushed through the holes in the side of the core liner into the core, and $\mathrm{E}_{\mathrm{h}}$ and $\mathrm{pH}$ were recorded as soon as the meter stabilized (typically less than $1 \mathrm{~min}$ ). In this manner $\mathrm{E}_{\mathrm{h}}$ and $\mathrm{pH}$ readings were taken at $2.5-\mathrm{cm}$ intervals the full length of the core sample. Because redox conditions changed upon collection and removal of the core from the sampler, $\mathrm{E}_{\mathrm{h}}$ readings were taken as quickly as possible and were always taken before $\mathrm{pH}$ readings. This approach for measuring redox potential in freshly sampled cores is predicated on the assumption that such measurements would reasonably reflect the in situ condition. Typically, all $\mathrm{E}_{\mathrm{h}}$ and $\mathrm{pH}$ readings for a given core were collected within a 10-min time period. Five such depth profiles were taken at SM-1, SM-10, and China Camp (Figures 5-1 through 5-3); one was taken at Bel Marin (Figure 5-1). An $\mathrm{E}_{\mathrm{h}} / \mathrm{pH}$ depth profile was not obtained on the core collected at SM-10U. To ensure proper function, $\mathrm{E}_{\mathrm{h}} / \mathrm{pH}$ probes and meters (Beckman 255 meter, Beckman Coulter, Fullerton, CA) were checked frequently ( $\sim$ hourly) using standard solutions (VWR International, West Chester, PA). A "poised" solution was used as the $\mathrm{E}_{\mathrm{h}}$ probe/meter calibration standard. $E_{h}$ values were calculated from measured $\mathrm{mV}$ readings of Pt-electrodes and corrected for the potential of the reference $\mathrm{AgCl}$ by adding $200 \mathrm{mV}$ (Light 1972) to the instrument reading.

\section{Invertebrate sampling}

Invertebrate specimens were collected at three sites: SM-1, SM-10, and R-44. Collections were made by hand over the period 10-12 June 2003. Three species were found in sufficient abundance for analysis. The ribbed mussel, Geukensia (= Modiolus) demissa, and yellow shore crab Hemigrapsus oregonensis were found at all three locations. Mudsnails Nassarius (= Ilyanassa) obsoletus were found only in a small tidal creek at SM-1. Five pooled samples of approximately $50 \mathrm{~g}$ wet-weight (excluding shell weight of molluscs) were collected for each species. Samples were collected in 4-oz. screw-top glass jars, frozen on dry ice as with sediment samples, and transported to the ERDC Omaha facility for analysis of total $\mathrm{THg}$ and $\mathrm{MeHg}$. 


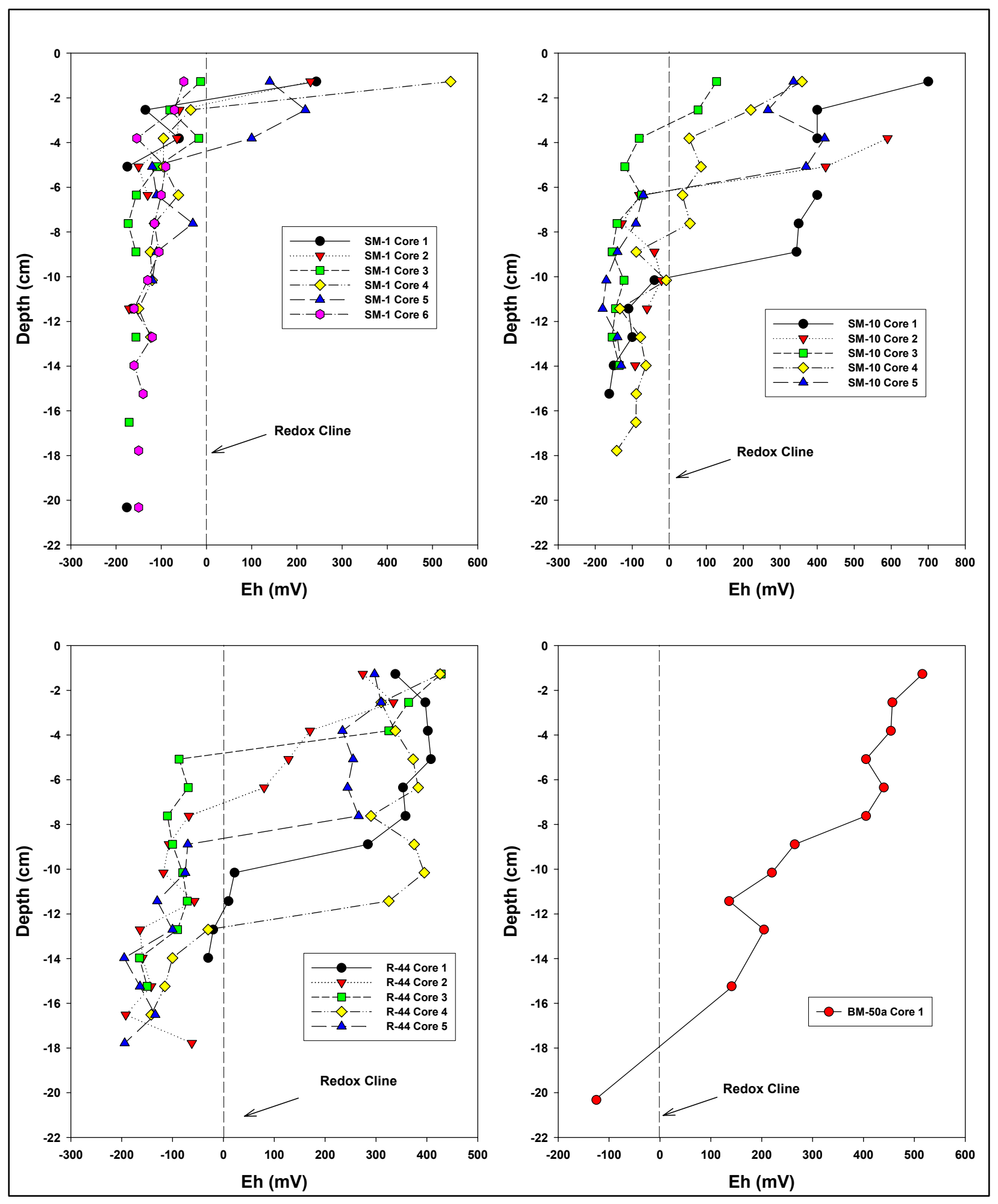

Figure 5-1. Depth profile of in situ redox potential measurements ion sections of replicate cores taken at HAAF Bay Edge (SM-1, SM-10), China Camp (R-44), and Bel Marin (BM-50a). Vertical dashed line is redox cline 


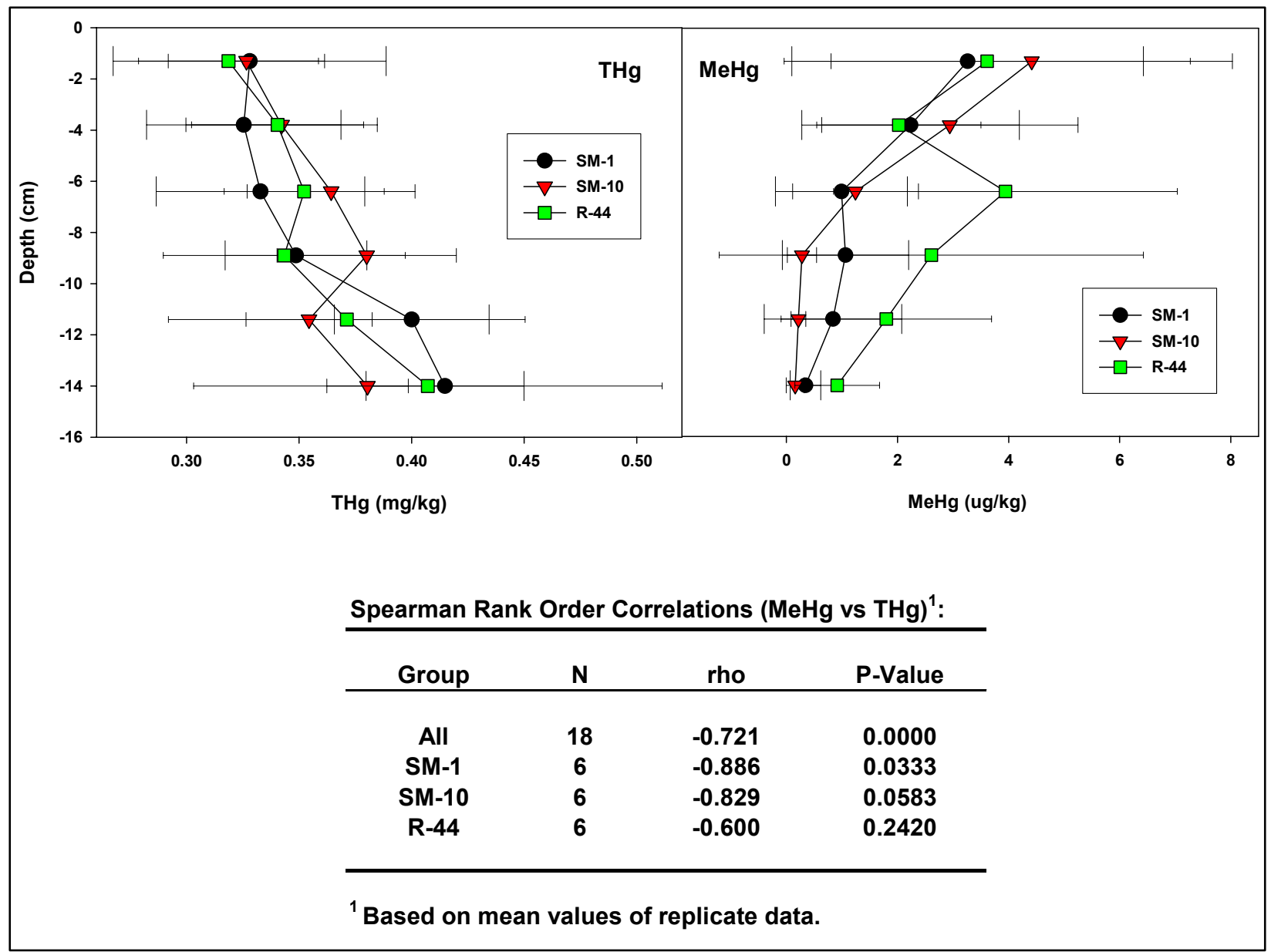

Figure 5-2. Depth profile comparisons and correlations for $\mathrm{THg}$ and $\mathrm{MeHg}$ in cores collected at HAAF $(\mathrm{SM}-1, \mathrm{SM}-10)$ and China Camp (R-44). Mean values and SD $(\mathrm{N}=5)$

\section{Sample preparation for analysis}

Frozen cores were manipulated in a glove box under nitrogen (Labconco, Kansas City, MO) continuously monitored with the aid of a probe and meter (Extech Instruments, Model 407510) to ensure internal atmospheric oxygen levels remained below 1 percent. Frozen cores were sectioned using a PVC pipe cutter at $2.5-\mathrm{cm}$ intervals along the entire length of the core. In this manner each core yielded six subsamples reflecting the depth profile of the core. Subsamples of corresponding depths for each replicate core taken at a given sampling point were composited. Plant stems and rocks were removed as much as possible from the samples. After compositing was completed, samples were refrozen on dry ice to minimize the potential loss of $\mathrm{MeHg}$ from the sample. Composite samples were then submitted for determination of $\mathrm{MeHg}$, $\mathrm{THg}$, total organic carbon (TOC), acid volatile sulfide with simultaneously extractable metal (mercury; AVS/SEM), total metals (aluminum, cesium, iron, lithium, manganese, phosphorus, selenium), particle size distribution (PSD), and clay mineralogy. Procedures for these analyses are described below. Frozen mussels and clams were partially thawed, shucked, and prepared for mercury analyses by lyophilization and 
grinding. Crabs were analyzed with exoskeleton. A 10- to 15-mg aliquot of each pooled sample was taken for separate lipid determination (Van Handel 1985).

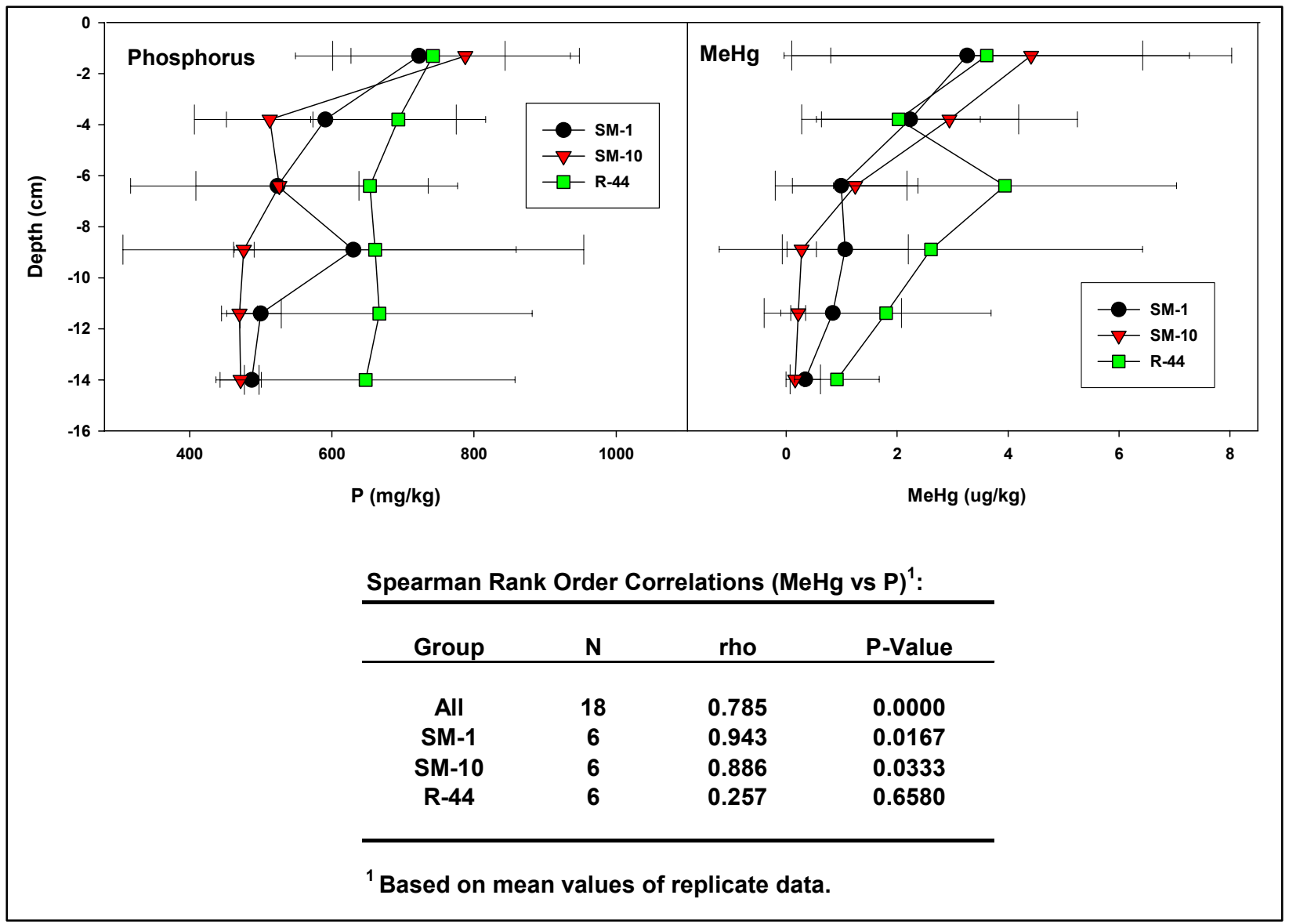

Figure 5-3. Depth profile comparisons and correlations for phosphorus $(\mathrm{P})$ and $\mathrm{MeHg}$ in cores collected at HAAF (SM-1, SM-10) and China Camp (R-44). Mean values and SD (N=5)

\section{Lipid analysis in invertebrate tissues}

Samples were weighed (10 to $50 \mathrm{mg}$ ) into a microcentrifuge tube then chilled in $1 \mathrm{~mL}$ of chloroform/methanol $(1: 1 \mathrm{v} / \mathrm{v})$ for $1 \mathrm{hr}$. The mixture was then transferred to a ground glass homogenizing tube with $3 \mathrm{~mL}$ of chloroform/methanol and homogenized thoroughly. The homogenate was then centrifuged at $3,000 \mathrm{rpm}$ for $5 \mathrm{~min}$. Three separate aliquots $(0.25 \mathrm{~mL}$ each) were transferred to individual test tubes. Volume of the remaining extract was determined and recorded. Standards were prepared by adding 0, 10, 25, 50, 100, 150, 200, and $250 \mu 1$ of $1 \mathrm{mg} / \mathrm{ml}$ soybean oil to $13-\times 100-\mathrm{mm}$ tubes (in triplicate). Solvent was evaporated from samples and standards on a dry heating block. Concentrated sulfuric acid $(100 \mu \mathrm{L})$ was added to each tube followed by heating on a dry block at $100{ }^{\circ} \mathrm{C}$ for $10 \mathrm{~min}$. After cooling, vanillin reagent $(2.4 \mathrm{~mL} /$ tube $)$ was added, followed by vortexing to mix. An aliquot $(250 \mu \mathrm{L})$ of each sample/standard was transferred to a 96-well plate and absorbance was measured at $490 \mathrm{~nm}$ to determine lipid content. 


\section{$\mathrm{THg}$ determination in sediments and invertebrate tissues}

THg analysis of all samples was based on EPA Method 7471A (USEPA 1992c). Briefly, sediment samples were dried at $105^{\circ} \mathrm{C}$ and ground with a mortar and pestle in preparation for analysis. For each dried sample, a 1.0-g aliquot was digested in a BOD bottle with concentrated hydrochloric acid and concentrated nitric acid for $15 \mathrm{~min}$ at room temperature. Each sample was then heated for $1 \mathrm{hr}$ with $99 \mathrm{~mL}$ reagent water and $15 \mathrm{~mL} 5$ percent $(\mathrm{w} / \mathrm{v})$ potassium permanganate at $95^{\circ} \mathrm{C}$. Samples were allowed to cool, after which $10 \mathrm{~mL}$ sodium chloride-hydroxylamine hydrochloride solution $\left(144 \mathrm{~g} \mathrm{NaCl}\right.$ and $144 \mathrm{~g} \mathrm{NH}_{2} \mathrm{OH} \cdot \mathrm{HCl}$ in $1 \mathrm{~L}$ reagent water) was added. An aliquot of the digestate was mixed with 10 percent $(\mathrm{w} / \mathrm{v})$ stannous chloride in 7 percent (v/v) hydrochloric acid solution and injected onto a CETAC M6000A Mercury Analyzer equipped with a long path cell. Sample absorption was monitored at $254 \mathrm{~nm}$.

\section{MeHg determination in sediments and invertebrate tissues}

$\mathrm{MeHg}$ concentrations in all samples were determined in an acidic aqueous medium using sample distillation and cold trapping prior to derivatization with sodium tetraethylborate. Volatile organomercury compounds were then separated and detected by gas chromatography and atomic fluorescence (Demuth and Heumann 2001). MeHg determinations were performed under clean room conditions by the procedure described previously (McFarland et al. 2002). Briefly, approximately $0.25 \mathrm{~g}$ of sediment was weighed into a Teflon container $(100 \mathrm{~mL}$ volume) containing $60 \mathrm{~mL} 0.4$ percent $\mathrm{HCl}$ and $200 \mu \mathrm{L} 1$ percent APDC (pyrrolidine carbodithioic acid, ammonium salt, 97 percent). The sample was distilled at $130{ }^{\circ} \mathrm{C}$ for 3.5 to $3.7 \mathrm{hr}$ under $60 \mathrm{~mL} \mathrm{~min}^{-1}$ flow of high purity nitrogen in a laminar flow hood. The distillate was collected and transferred to a 250-mL Erlenmeyer flask and the volume adjusted to approximately $100 \mathrm{~mL}$ with Barnstead Nanopure water. The flask was topped with a four-way valve glass stopcock. Ethylation of the $\mathrm{Hg}$ species was initiated and allowed to proceed (with valves closed) $20 \mathrm{~min}$ by addition of $2 \mathrm{M}$ sodium acetate buffer and 1 percent sodium tetraethylborate (in 2 percent $\mathrm{KOH}$ ). High purity nitrogen was then bubbled through the reaction mixture for $20 \mathrm{~min}$, and organomercury species were collected in a quartz tube packed with 3 g Carbotrap 20/40 mesh graphitized carbon black. The quartz tube was then inserted into a tubular heating jacket heated to $350{ }^{\circ} \mathrm{C}$ for 2 min under a flow of ultra high purity argon, which proceeded through a $1-\mathrm{m}$ U-shaped glass column ( $2 \mathrm{~mm} \mathrm{ID,} 0.25$ in OD) with 3 percent OV-17 on Chromasorb WHP 80/100 mesh packing fitted into a HP 5890 gas chromatography oven held at $100{ }^{\circ} \mathrm{C}$, and flow was directed to a quartz pyrolysis tube held at approximately $700{ }^{\circ} \mathrm{C}$. Pyrolysis products were observed by using a Tekran Model 2500 CVAFS Mercury Detector. Analog data were collected on a Shimadzu C-R4A Chromatopac integrator.

\section{Total metals determinations in sediments and invertebrate tissues}

Soil sub-samples were dried and weighed $(1.0 \mathrm{~g})$ into glass digestion vessels. The samples were digested according to EPA Method 3050B (USEPA 1992a) using the hotplate technique. Once digested, the corresponding solutions were 
filtered, diluted as necessary, and spiked with Yittrium internal standard for metals analysis by ICP-AES using EPA Method 6010B (USEPA, 1992b). The instrument used was a Perkin Elmer Optima 3000DV equipped with a cyclonic spray chamber and cross flow nebulizer. Nebulizer gas flow was set to $0.8 \mathrm{~mL} / \mathrm{min}$ according to manufacturer's suggestions and optimization experiments; a plasma power of $1,320 \mathrm{~W}$ was used. Pre- and post-digestion analytical spikes were added for quality control for all analytical batches in addition to using laboratory control standards.

\section{Determination of acid volatile sulfide and simultaneously extractable $\mathrm{Hg}$ in sediments}

AVS-SEM (Hg) in the sediment was determined using the diffusion method of Leonard et al. (1996). The soil sub-sample was placed in a sealed 500-mL glass bottle with $50 \mathrm{~mL}$ of deionized water to which an aliquot of hydrochloric acid was added to make the final acid concentration $1 \mathrm{M}$. The evolved sulfide gas was collected in a 30-mL vial containing $0.25 \mathrm{M}$ sodium hydroxide inside the sealed 500-mL container. Sulfide was measured in the sodium hydroxide capture solution using standard colorimetric techniques. The colorimetric method (Lachat Instruments, Hach Corporation, Loveland, $\mathrm{CO}$ ) uses methylene blue color formation to detect dissolved sulfide. Metals extracted from the soil sample were analyzed by ICP-AES, except for $\mathrm{Hg}$, which was determined by cold vapor atomic fluorescence as described above, after the hydrochloric acid solution was filtered to $0.45 \mu \mathrm{m}$.

\section{Determination of total organic carbon in sediments}

Total organic carbon was determined through conversion of organic carbon in a sample to carbon dioxide $\left(\mathrm{CO}_{2}\right)$ by high temperature combustion. The $\mathrm{CO}_{2}$ formed was measured directly by a linearized non-dispersive infrared detector. The method was based on EPA Method 9060 (USEPA 1989). Briefly, 1 to $2 \mathrm{~g}$ of wet sample was placed in a porcelain dish and concentrated nitric acid was added drop-wise until any observed effervescence ceased. The sample was then placed in an oven at $75^{\circ} \mathrm{C}$ until dry ( 15 min minimum). The dried sample was ground using a mortar and pestle. Samples were analyzed using a Dohrmann 183 Boat Sampling Module and a Dohrmann DC-190 High Temperature TOC Analyzer. The instrument was calibrated using a blank and a 10,000-ppm carbon standard (4.25 g potassium hydrogen phthalate [Sigma-Aldrich, Milwaukee, WI] in $200 \mathrm{~mL}$ organic-free reagent grade water) according to the instrument manufacturer's instructions. A second source standard (Environmental Resource Associates, Arvada, $\mathrm{CO}$ ) was analyzed following calibration as a quality control measure. Continuing calibration verification (CCV) standards were used to check the validity of the calibration after every 10 samples. All samples were analyzed in quadruplicate and the average result reported. 


\section{Determination of particle size distribution in sediments}

Particle size distributions of HAAF soil/sediment cores were determined using the hydrometer method of Day (1956) as modified by Patrick (1958). Particles were separated into size fractions of $>50 \mu \mathrm{m}$ (sand), $50-2 \mu \mathrm{m}$ (silt), and $<2 \mu \mathrm{m}$ (clay) by suspension of $40 \mathrm{~g}$ dry material in $1 \mathrm{~L}$ of a dispersing solution (sodium metaphosphate at $\mathrm{pH} 8.3$ ). An ASTM hydrometer (152H) placed in the suspension was read at specified sedimentation times for the various size fractions based on Stokes' equation. Results were reported as percentages of sand, silt, and clay.

\section{Identification of clay minerals in sediments}

Clay mineral identification was determined using X-ray diffraction (XRD) of randomly oriented packed powders. A Philips PW1800 Automated Powder Diffractometer system was utilized to collect X-ray diffraction patterns employing standard techniques for phase identification. The run conditions included $\mathrm{Cu} \mathrm{K}_{\alpha}$ radiation and scanning from 2 to $65^{\circ} 2 \theta$ with collection of the diffraction patterns accomplished using the PC-based, Windows version of Datascan, and analysis of the patterns using the Jade program (both from Materials Data, Inc.). In preparation for XRD analysis, a portion of the sample was ground in a mortar and pestle to pass a $45-\mu \mathrm{m}$ mesh sieve (No. 325). Bulk sample random powder mounts were analyzed using XRD to determine the mineral constituents present in each sample. To determine the type of phyllosilicates present, oriented samples of the $<4 \mu \mathrm{m}$ size fraction of each sample were prepared and XRD patterns were obtained. These samples were then placed in an ethylene glycol atmosphere overnight at room temperature, and an X-ray diffraction pattern was collected for each sample. Samples showing expansion of the crystal structure after exposure to an ethylene glycol atmosphere compared to air-dried pattern indicate expandable smectitic clays. Patterns obtained before and after exposure to ethylene glycol were compared to determine the amount of expandable clay present. Whole-rock mineral amounts were determined quantitatively using integrated peak areas (derived from peak-decomposition/profile-fitting methods) and empirical reference intensity ratio (RIR) factors determined specifically for the diffractometer used in data collection. The total phyllosilicate (clay and mica) abundance of the samples was determined on the whole-rock XRD patterns using combined $\{001\}$ and $\{\mathrm{hkl}\}$ clay mineral reflections and suitable empirical RIR factors.

\section{Statistical analysis}

Statistical analyses were performed using SAS procedures (SAS Institute, Inc. 2001) and SigmaStat, version 3.0 (SPSS, Inc., Chicago, IL). Parametric comparison test assumptions were checked for violations using the ShapiroWilk's test for normality of residuals, and a modification of Hartley's $F$-max test for equality of variances (Shoemaker 2003). Site data failing the normality assumption were compared using the nonparametric Kruskal-Wallis test. Site data passing the normality test were compared using $t$-tests for equal or unequal variances. A significance level of 0.05 was used for all statistical tests. 
Nondetects were substituted as one-half detection limit prior to analysis. Figures were produced using SigmaPlot, version 8.0 (SPSS, Inc., Chicago, IL).

\section{Results and Discussion}

\section{Total $\mathrm{Hg}$ and $\mathrm{MeHg}$ levels in sediments}

$\mathrm{THg}$ and MeHg in relation to depth within the sediment. The $\mathrm{THg}$ concentrations did not differ greatly between the primary sample sites, SM-1 and SM-10 at HAAF, and R-44 at China Camp, but they increased with depth within the sediment (Table 5-2, Figure 5-2). The $\mathrm{MeHg}$ concentrations were highly variable (SDs as large as the means), higher in the first 5.1-cm layers at SM-1 and SM-10, but lower in the deeper layers (Table 5-2, Figure 5-2). MeHg constituted about 1 percent of THg down to almost the 10.2-cm depth (Table 5-2). The THg concentrations were far lower at Bel Marin than at both other sites, i.e., almost one-half to two-thirds, and $\mathrm{MeHg}$ was well above 1 percent in all depth sections - except the 5.1- to 7.6-cm section (Table 5-2). The methylation of $\mathrm{Hg}$ is apparently higher at Bel Marin than at both other sites, consistent with earlier observations (McFarland et al. 2002, 2003a). SM-10U was sampled to explore a depth profile at a higher elevation of the marsh. This core was sectioned using visually distinct horizons as a criterion (Table 5-3). It was found that in this core, the highest $\mathrm{MeHg}$ concentrations occurred deeper in the sediment, i.e., at 17.8 to $40.6 \mathrm{~cm}$, than at the other sites.

\section{Other parameters important for the cycling of $\mathrm{THg}$ and $\mathrm{MeHg}$ in sediments}

Sediment quality characteristics. Sediment quality characteristics for HAAF (SM-1 and SM-10) and China Camp (R-44) are summarized in Table 5-4. Additional data are tabulated for sediment quality (HAAF SM-10U and Bel Marin BM-50a) in Table A1, Appendix A, and for clay mineralogy (all sites) in Tables A11-A15, Appendix A.

The concentrations and depth profiles of organic carbon were similar at HAAF (SM-1 and SM-10; Table 5-4). Surficial sediment layers were usually relatively richer in sand and organic matter, and deeper layers were more compacted and contained relatively more silt and clay. The sulfide (AVS) concentration and redox potential were inversely related to depth. The redox cline occurred within 2.5 to $5.1 \mathrm{~cm}$ of the surface at SM-1 and at 3.8 to $10.2 \mathrm{~cm}$ at SM-10 (Figure 5-1). The redox potential barely changed below the cline at HAAF. At the higher elevation site, SM-10U, redox potential and $\mathrm{pH}$ were not measured. The AVS concentration was measured and found to be elevated, i.e., $1,600 \mu \mathrm{g} \mathrm{g}^{-1}$, deeper than $30.5 \mathrm{~cm}$ below the sediment surface, the same depth at which a dark color was observed indicating a reducing environment (Tables A1 and A3). The sediments at China Camp were less organic and more sulfidic near the surface (Table 5-4) compared to those at HAAF (SM-1 and SM-10), and the fines concentration was very low $(<1$ percent). The redox cline in these sediments ranged from 5.1 to $12.7 \mathrm{~cm}$ below the surface (Figure 5-3). The sediment 
at Bel Marin was the least organic with TOC $<2$ percent (Table A1), and it was more oxic with the redox cline occurring at about $17.8 \mathrm{~cm}$ (Figure 5-4). AVS was below detection at the sediment surface, but about $1,100 \mu \mathrm{g} \mathrm{g}^{-1}$ at a depth of 12.7 to $15.2 \mathrm{~cm}$.

\begin{tabular}{|c|c|c|c|}
\hline \multicolumn{4}{|c|}{$\begin{array}{l}\text { Table 5-2 } \\
\text { Total Hg and MeHg Levels in HAAF Bay Edge (SM-1, SM-10; N=5), } \\
\text { China Camp (R-44; } N=5 \text { ), Bel Marin (BM-50a; } N=1 \text { ), and HAAF } \\
\text { Inland (SM-10U; } N=1 \text { ) Soil/Sediment Cores. Mean (SD) }\end{array}$} \\
\hline Depth, cm & THg, ng g $^{-1}$ & MeHg, ng g $^{-1}$ & MeHg, \% \\
\hline \multicolumn{4}{|c|}{ SM-1 } \\
\hline $0-2.5$ & $330(61)$ & $3.3(3.2)$ & $0.92(1.1)$ \\
\hline $2.5-5.1$ & $330(43)$ & $2.2(2.0)$ & $0.62(0.69)$ \\
\hline $5.1-7.6$ & $330(46)$ & $0.99(1.2)$ & $0.30(0.32)$ \\
\hline $7.6-10.2$ & $350(32)$ & $1.1(1.1)$ & $0.28(0.37)$ \\
\hline $10.2-12.7$ & $400(34)$ & $0.84(1.2)$ & $0.20(0.31)$ \\
\hline $12.7-15.2$ & $420(35)$ & $0.34(0.27)$ & $0.50(1.0)$ \\
\hline \multicolumn{4}{|c|}{ SM-10 } \\
\hline $0-2.5$ & $330(35)$ & $4.4(3.6)$ & $1.3(0.93)$ \\
\hline $2.5-5.1$ & $340(43)$ & $2.9(2.3)$ & $0.69(0.62)$ \\
\hline $5.1-7.6$ & $360(37)$ & $1.2(1.1)$ & $0.30(0.32)$ \\
\hline $7.6-10.2$ & $380(40)$ & $0.28(0.26)$ & $0.07(0.07)$ \\
\hline $10.2-12.7$ & $350(28)$ & $0.22(0.13)$ & $0.07(0.04)$ \\
\hline $12.7-15.2$ & $380(18)$ & $0.16(0.16)$ & $0.04(0.04)$ \\
\hline \multicolumn{4}{|c|}{$\mathrm{R}-44$} \\
\hline $0-2.5$ & $320(40)$ & $3.6(3.7)$ & $1.2(1.3)$ \\
\hline $2.5-5.1$ & $340(38)$ & $2.0(1.5)$ & $0.63(0.47)$ \\
\hline $5.1-7.6$ & $350(36)$ & $3.9(3.1)$ & $1.1(0.89)$ \\
\hline $7.6-10.2$ & $340(54)$ & $2.6(3.8)$ & $0.79(1.1)$ \\
\hline $10.2-12.7$ & $370(79)$ & $1.8(1.9)$ & $0.54(0.64)$ \\
\hline $12.7-15.2$ & $410(100)$ & $0.91(0.76)$ & $0.25(1.2)$ \\
\hline \multicolumn{4}{|c|}{ SM-10U } \\
\hline $0-7.6$ & 480 & 1.7 & 0.6 \\
\hline $7.6-10.2$ & 710 & 0.79 & 0.11 \\
\hline $10.2-14.0$ & 500 & 0.9 & 0.18 \\
\hline $14.0-17.8$ & 530 & 1.4 & 0.27 \\
\hline $17.8-24.1$ & 550 & 13 & 2.3 \\
\hline $24.1-30.5$ & 500 & 6.9 & 1.4 \\
\hline $30.5-40.6$ & 510 & 3.1 & 0.61 \\
\hline \multicolumn{4}{|c|}{ BM-50a } \\
\hline $0-2.5$ & 190 & 2.2 & 1.1 \\
\hline $2.5-5.1$ & 190 & 2.4 & 1.2 \\
\hline $5.1-7.6$ & 190 & 0.8 & 0.41 \\
\hline $7.6-10.2$ & 170 & 2 & 1.2 \\
\hline $10.2-12.7$ & 170 & 2.4 & 1.5 \\
\hline $12.7-15.2$ & 160 & 2.6 & 1.6 \\
\hline
\end{tabular}




\begin{tabular}{|c|c|}
\hline \multicolumn{2}{|c|}{$\begin{array}{l}\text { Table 5-3 } \\
\text { Appearance of Seven Visually Different Depth Sections of Upland } \\
\text { Salt Marsh Core Sample (SM-10U) }\end{array}$} \\
\hline Depth (cm) & Observed Appearance \\
\hline $0-7.6$ & Loose plant detritus \\
\hline $7.6-10.2$ & Compacted plant detritus \\
\hline $10.2-14.0$ & Red and light gray compacted material \\
\hline $14.0-17.8$ & Light gray compacted material \\
\hline $17.8-24.1$ & Medium gray compacted material \\
\hline $24.1-30.5$ & Dark gray compacted material \\
\hline $30.5-40.6$ & Dark gray compacted material with black flecks \\
\hline
\end{tabular}

\begin{tabular}{|c|c|c|c|c|c|c|c|}
\hline \multicolumn{8}{|c|}{$\begin{array}{l}\text { Table 5-4 } \\
\text { Sediment Quality Characteristics of HAAF (SM-1, SM-10) and China Camp (R-44) } \\
\text { Soil/Sediment Cores, Mean (SD) }\end{array}$} \\
\hline Depth Section, cm & $E_{h}, \mathrm{mV}$ & AVS, $\mu \mathrm{g} / \mathrm{g}$ & TOC, $\%$ & Sand, \% & Silt, \% & Clay, \% & Fines, $\%$ \\
\hline \multicolumn{8}{|c|}{ SM-1 } \\
\hline $0-2.5$ & $180(210)$ & $51(83)$ & $4.4(0.9)$ & $61(29)$ & $21(24)$ & $18(6)$ & $0.39(0.29)$ \\
\hline $2.5-5.1$ & $-49(86)$ & $110(150)$ & $4.5(0.8)$ & $51(30)$ & $30(24)$ & $20(7)$ & $0.50(0.30)$ \\
\hline $5.1-7.6$ & $-110(35)$ & $20(19)$ & $4.2(0.5)$ & $44(26)$ & $35^{2}(24)$ & $21^{2}(3)$ & $0.56^{2}(0.26)$ \\
\hline $7.6-10.2$ & $-110(59)$ & $140(150)$ & $3.6(0.5)$ & $57(30)$ & $23(25)$ & $19(5)$ & $0.43(0.30)$ \\
\hline $10.2-12.7$ & $-160(9)$ & $150(220)$ & $3.2(0.7)$ & $50(30)$ & $25(25)$ & $26(3)$ & $0.50(0.26)$ \\
\hline $12.7-15.2$ & $-160^{1}$ & $230(210)$ & $2.7(0.6)$ & $31(21)$ & $36(19)$ & $33(8)$ & $0.69(0.21)$ \\
\hline \multicolumn{8}{|c|}{ SM-10 } \\
\hline $0-2.5$ & $380(240)$ & $30(30)$ & $4.7(1.1)$ & 31 (11) & $53(8)$ & $16(5)$ & $0.69(0.11)$ \\
\hline $2.5-5.1$ & $280(280)$ & $24(27)$ & $4.7(0.5)$ & $32(11)$ & $53(9)$ & $15(3)$ & $0.68(0.11)$ \\
\hline $5.1-7.6$ & $42(210)$ & $51(74)$ & $4.2(0.7)$ & $25(11)$ & $60(8)$ & $16(4)$ & $0.75(0.11)$ \\
\hline $7.6-10.2$ & $-16(210)$ & $66(64)$ & $3.6(0.5)$ & $15^{2}(1)$ & $69^{2}(2)$ & $16(1)$ & $0.85^{2}(0.01)$ \\
\hline $10.2-12.7$ & $-130(45)$ & $70(28)$ & $3.3(0.2)$ & $13^{2}(6)$ & $67^{2}(7)$ & $21(2)$ & $0.87^{2}(0.06)$ \\
\hline $12.7-15.2$ & $-110(36)$ & $89(63)$ & $2.9(0.1)$ & $12^{2}(3)$ & $65^{2}(3)$ & $23(3)$ & $0.88^{2}(0.03)$ \\
\hline \multicolumn{8}{|c|}{ R-44 } \\
\hline $0-2.5$ & $350(72)$ & $120(240)$ & $3.1(0.4)$ & $12(9)$ & $58(6)$ & 31 (9) & $0.89(0.09)$ \\
\hline $2.5-5.1$ & $290(92)$ & $50(90)$ & $3.6(0.7)$ & $20(8)$ & $53(8)$ & $27(9)$ & $0.80(0.08)$ \\
\hline $5.1-7.6$ & $200(190)$ & $120(210)$ & $3.7(0.8)$ & $14(10)$ & $52(9)$ & $35(9)$ & $0.86(0.10)$ \\
\hline $7.6-10.2$ & $76(230)$ & $140(280)$ & $3.7(0.6)$ & $5.4(3.2)$ & $56(4)$ & $42(8)$ & $0.95(0.03)$ \\
\hline $10.2-12.7$ & $15(180)$ & $51(54)$ & $3.8(0.6)$ & $7.2(2.8)$ & $56(6)$ & $37(6)$ & $0.93(0.03)$ \\
\hline $12.7-15.2$ & \begin{tabular}{|l|}
$-130(66)$ \\
\end{tabular} & $35(23)$ & $3.3(0.5)$ & $4.4(3.5)$ & $56(5)$ & $40(5)$ & $0.96(0.03)$ \\
\hline
\end{tabular}




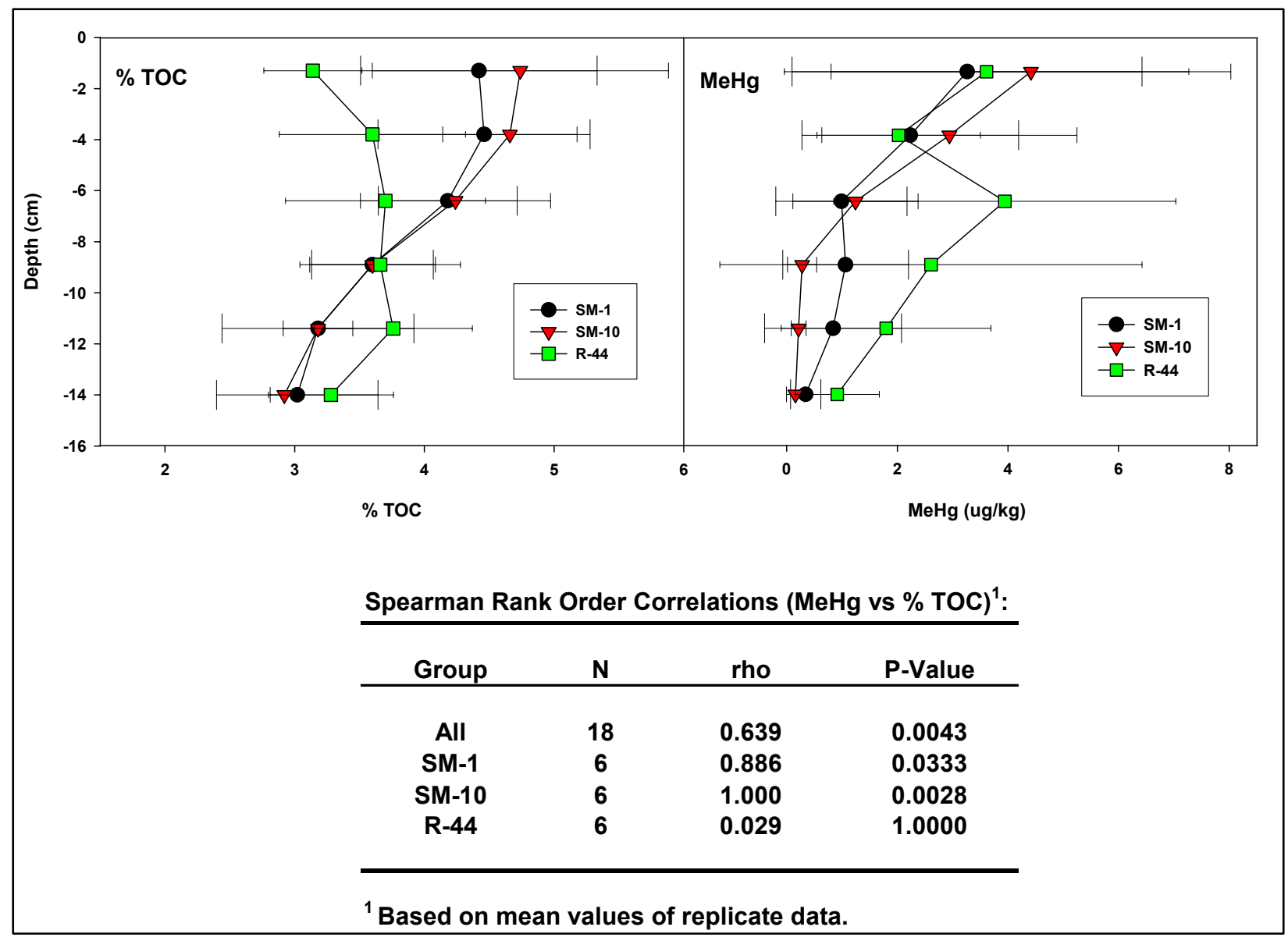

Figure 5-4. Depth profile comparisons and correlations for total organic carbon (\%) and $\mathrm{MeHg}$ in cores collected at HAAF (SM-1, SM-10) and China Camp (R-44). Mean values and SD (N=5)

Major and trace elements. Results for analysis of major and trace elements are summarized in Tables A2 and A3 (SM-1, SM-10, R-44, BM-50a, SM-10U). Aluminum $(\mathrm{Al})$ and iron $(\mathrm{Fe})$ were detected as major elements at all sites. The levels of these elements increased with depth at HAAF (SM-1, SM-10, SM-10U), but did not show this relationship at HAAF (R-44) and Bel Marin (BM-50a). Trace elements included cesium (Cs), lithium (Li), manganese (Mn), phosphorus $(\mathrm{P})$, and selenium (Se). The concentrations increased in the order of $\mathrm{Se}<\mathrm{Cs}<\mathrm{Li}$ $<\mathrm{Mn}<\mathrm{P}$ at all three sites at all depths. The Se and Cs concentrations remained constant at all depth profiles at all sites. The Mn concentration showed a tendency to increase with depth at two sites, i.e. SM-10 and R-44, but remained constant at all depths at two other sites, i.e., SM-1 and BM-50a. The Mn concentration was a factor of ten higher in the surficial sediment at SM-10U than at SM-10. The Li concentration increased with depth at HAAF (SM-1, SM-10, SM-10U), but remained constant at all depths at China Camp (R-44) and Bel Marin (BM-50a). The phosphorus concentration generally decreased with depth. Within HAAF, it was approximately two times higher at the higher elevation site, SM-10.

Significant relationships between $\mathrm{MeHg}$ and other parameters and depth within the sediment. The tentative relationships between $\mathrm{MeHg}$ 
concentrations and other parameters, and depth within the sediment at HAAF (SM-1 and SM-10) and China Camp (R-44) were explored using statistics. A non-parametric statistical test (Tukey's on Ranks) was employed, because unequal variances were observed in some cases. Statistically significant relationships were established among $\mathrm{THg}, \mathrm{MeHg}, \mathrm{P}, \mathrm{Mn}, \mathrm{TOC}, \mathrm{E}_{\mathrm{h}}$, and $\mathrm{pH}$. Data tables showing these relationships are located in Tables A4 through A10, respectively.

For THg, significant differences were observed across the depth profile of SM-1, but not SM-10 and R-44. For MeHg and P, significant differences were observed across the depth profile of SM-10, but not SM-1 and R-44. For Mn, significant differences were observed across the depth profile of SM-10 and $\mathrm{R}-44$, but not $\mathrm{SM}-1$. For TOC, $\mathrm{E}_{\mathrm{h}}$, and $\mathrm{pH}$, significant differences were observed across the depth profile of all three.

The parameters described in the preceding paragraph also showed statistically significant correlation (Spearman Rank Order Correlation; $\mathrm{P}<0.050$ ) with changes in $\mathrm{MeHg}$ concentration (Figures 5-2 through 5-6). When measurements from SM-1, SM-10, and R-44 were combined as a single group, MeHg correlated positively with $\mathrm{P}$ (Figure 5-3), TOC (Figure 5-4), and $\mathrm{E}_{\mathrm{h}}$ (Figure 5-5), and negatively with $\mathrm{THg}$ (Figure 5-2) and Mn (Figure A1). Correlations performed on a per-site basis were not as clearcut. THg showed a negative correlation with changes in MeHg concentrations for the depth profile of SM-1, but not SM-10 and R-44 (Figure 5-2). Both P (Figure 5-3) and percent TOC (Figure 5-4) showed a strong positive correlation with changes in $\mathrm{MeHg}$ concentrations at SM-1 and SM-10, but not R-44. SM-10 and R-44, but not SM-1, showed negative correlations between $\mathrm{Mn}$ and $\mathrm{MeHg}$ (Figure A1). $\mathrm{E}_{\mathrm{h}}$ showed a strong positive correlation with changes in MeHg concentrations for SM-1 and SM-10, but not R-44 (Figure 5-5). A negative correlation between $\mathrm{pH}$ and $\mathrm{MeHg}$ was observed for SM-1, but not SM-10 and R-44 (Figure 5-6).

SM-10 was the only site with statistically significant differences along its depth profile for $\mathrm{MeHg}$. Significant differences for $\mathrm{P}, \mathrm{TOC}$, and $\mathrm{E}_{\mathrm{h}}$ were also seen at SM-10, and this further reinforces correlations between $\mathrm{MeHg}$ and these parameters at this site (Figures 5-3, 5-4, and 5-5, respectively). Parallel correlations for these same parameters at SM-1 (Figures 5-3, 5-4, and 5-5, respectively) provide additional support to the observation that these three parameters are associated with $\mathrm{MeHg}$ in intertidal sediments at HAAF.

The correlation observed between $\mathrm{P}$ and $\mathrm{MeHg}$ may be related to sediment phosphate serving as a nutrient for sediment microorganisms responsible for $\mathrm{Hg}$ methylation. Organic carbon also provides a carbon substrate for microorganisms and in a similar manner might support production of $\mathrm{MeHg}$. Additionally, $\mathrm{MeHg}$ is known to associate with organic carbon, and correlations between $\mathrm{MeHg}$ and TOC may be related to organic carbon's contribution to a favorable environment for retention of MeHg. In situ $\mathrm{pH}$ data indicated sediment was most acidic at the surface, consistent with a predicted elevation in organic acid content resulting from microbial degradation of sediment organic carbon (Marvin-DiPasquale et al. 2003). Others have reported elevated $\mathrm{Hg}$ methylation rates at low $\mathrm{pH}$ in freshwater systems (Winfrey and Rudd 1990). 


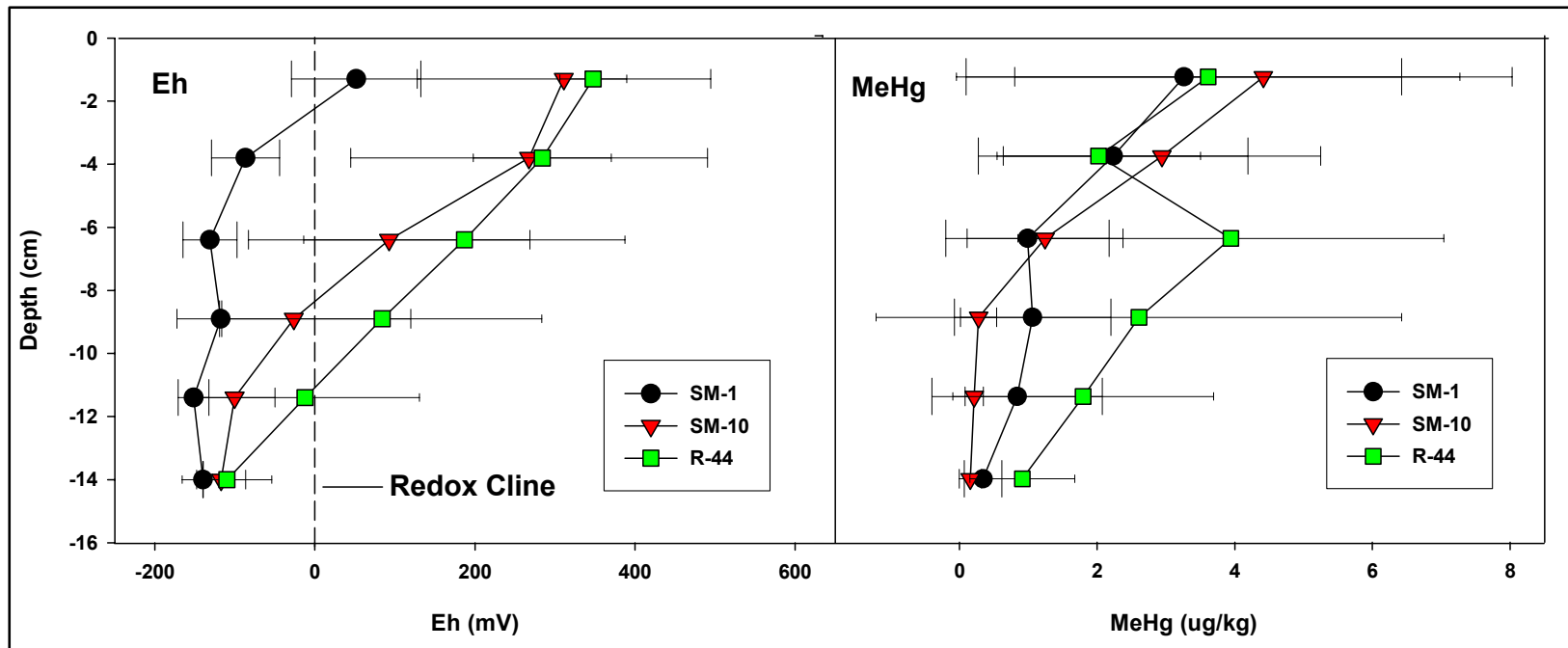

Spearman Rank Order Correlations (MeHg vs Eh) ${ }^{1}$ :

\begin{tabular}{cccc}
\hline Group & N & rho & P-Value \\
\hline All & 18 & 0.775 & 0.0000 \\
SM-1 & 6 & 0.943 & 0.0167 \\
SM-10 & 6 & 1.000 & 0.0028 \\
R-44 & 6 & 0.714 & 0.1360 \\
\hline
\end{tabular}

${ }^{1}$ Based on mean values of replicate data.

Figure 5-5. Depth profile comparisons and correlations for redox potential $\left(E_{h}\right)$ and $\mathrm{MeHg}$ in cores collected at HAAF (SM-1, SM-10) and China Camp (R-44). Mean values and SD (N=5)

Highest levels of $\mathrm{MeHg}$ were observed in highly oxygenated upper sediment strata as indicated by positive $\mathrm{E}_{\mathrm{h}}$ readings (Figure 5-5). Under oxic conditions, Fe and $\mathrm{Mn}$ form oxyhydroxides that may bind $\mathrm{MeHg}$. All three metals were detected at significant concentrations (Table A2) in sediment core samples, and may have exerted a sorptive influence that contributed to elevated surface MeHg. Sulfatereducing bacteria (SRB) are the primary producers of $\mathrm{MeHg}$ in sediment, and these strict anaerobes inhabit an $\mathrm{E}_{\mathrm{h}}$ range of $-100 \mathrm{mV}$ to $+100 \mathrm{mV}$ (Bartlett and Craig 1981) suggesting methylation would be most favored at depths below 5.1 $\mathrm{cm}$. However, SRB activity may be elevated in the oxygenated root zones where they occupy anaerobic "microzones" (Marvin-DiPasquale et al. 2003). Given the dense S. foliosa vegetation found in areas sampled for this study, such an explanation is certainly plausible and would account for elevated $\mathrm{MeHg}$ at the surface. $\mathrm{E}_{\mathrm{h}}$ and $\mathrm{pH}$ also influence mercury speciation as indicated in Figure 5-7. Data collected at Hamilton (SM-1 and SM-10) and China Camp (R-44) suggest that $\mathrm{Hg}$ would be expected to exist in its elemental form $\left(\mathrm{Hg}^{0}\right)$ at the surface but as $\mathrm{HgS}$ at lower depths. $\mathrm{HgS}$ is insoluble and would not be available to microorganisms, whereas $\mathrm{Hg}^{0}$ would be available for conversion to $\mathrm{MeHg}$. The diagram in Figure 5-7 is based on measurements taken under laboratory conditions, but if assumptions of the model are valid at Hamilton, then $\mathrm{E}_{\mathrm{h}}-\mathrm{pH}$ influences on $\mathrm{Hg}$ bioavailability could help explain elevated surface levels of $\mathrm{MeHg}$. 


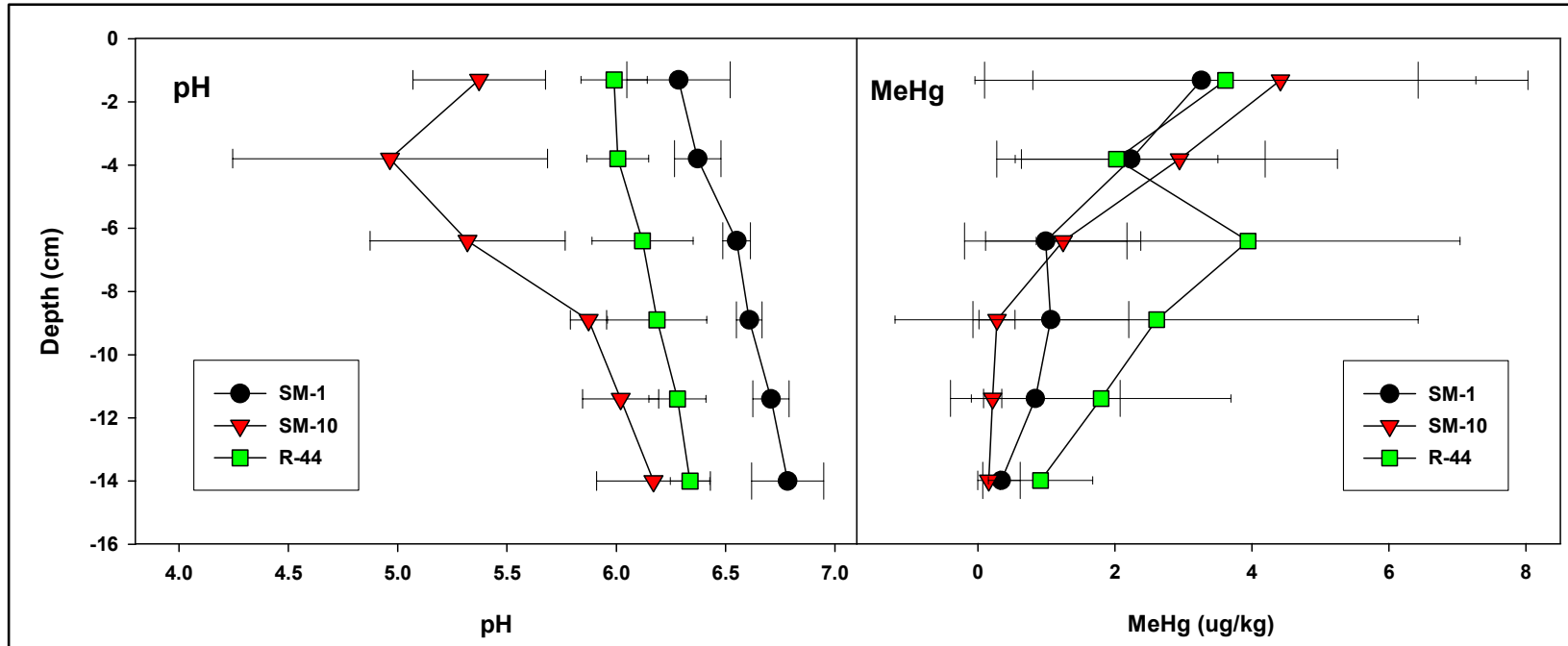

Spearman Rank Order Correlations (MeHg vs pH) ${ }^{1}$ :

\begin{tabular}{cccc}
\hline Group & N & rho & P-Value \\
\hline All & 18 & -0.342 & 0.1610 \\
SM-1 & 6 & -0.943 & 0.0167 \\
SM-10 & 6 & -0.829 & 0.0583 \\
R-44 & 6 & -0.714 & 0.1360 \\
\hline
\end{tabular}

${ }^{1}$ Based on mean values of replicate data.

Figure 5-6. Depth profile comparisons and correlations for $\mathrm{pH}$ and $\mathrm{MeHg}$ in cores collected at HAAF $(\mathrm{SM}-1, \mathrm{SM}-10)$ and China Camp (R-44). Mean values and SD (N=5)

\section{THg and MeHg levels in macrofauna}

The highest concentration of $\mathrm{THg}$ (100.9 $\mathrm{ng} \mathrm{g}^{-1}$ wet weight) was found in snails from HAAF site SM-1 (Table 5-5). THg in snails from SM-1 was significantly higher than in mussels from SM-10 and crabs from R-44, and $\mathrm{THg}$ in mussels from R-44 was significantly higher than in mussels from SM-10 (Figure 5-9). THg concentrations in crabs (Table 5-5) were approximately equal at all sites ranging from $18.1 \mathrm{ng} \mathrm{g}^{-1}$ (R-44) to $21.3 \mathrm{ng} \mathrm{g}^{-1}$ (SM-10). THg concentrations in mussels (Table 5-5) varied among sites with concentrations ranging from $15.7 \mathrm{ng} \mathrm{g}^{-1}$ (SM-10) to $29.3 \mathrm{ng} \mathrm{g}^{-1}$ (R-44). 


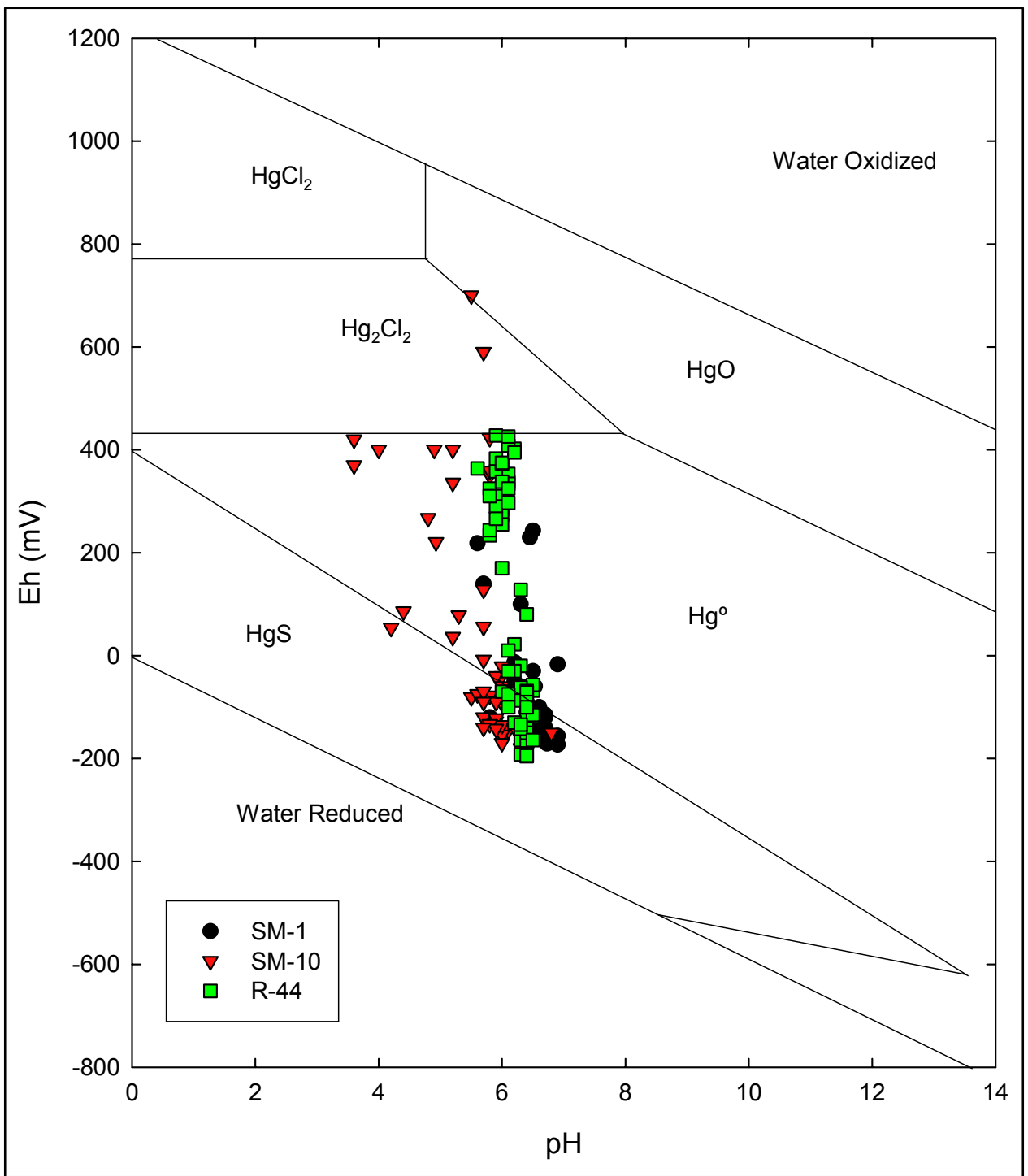

Figure 5-7. $\mathrm{E}_{\mathrm{h}}-\mathrm{pH}$ diagram (Mills 1997) populated with data from samples collected at HAAF (SM-1, SM-10) and China Camp (R-44)

The highest concentration of $\mathrm{MeHg}$ (39.5 $\mathrm{ng} \mathrm{g}^{-1}$ wet weight) was found in snails from SM-1 (Table 5-5). MeHg in snails from SM-1 was significantly higher than in mussels from SM-1 and crabs from R-44 (Figure 5-9). MeHg concentrations in crabs and mussels varied among sites with the highest crab $\mathrm{MeHg}$ concentrations (14.2 $\left.\mathrm{ng} \mathrm{g}^{-1}\right)$ at SM-10 whereas highest mussel MeHg concentrations (16 $\mathrm{ng} \mathrm{g}^{-1}$ ) were found at the reference site (R-44). MeHg as a percentage of THg (Table 5-5) ranged from 19.9 percent (R-44) to 67.4 percent (SM-10) for crabs, and 20.5 percent (SM-1) to 53.8 percent (R-44) for mussels; for snails, it was 39.9 percent (SM-1). 

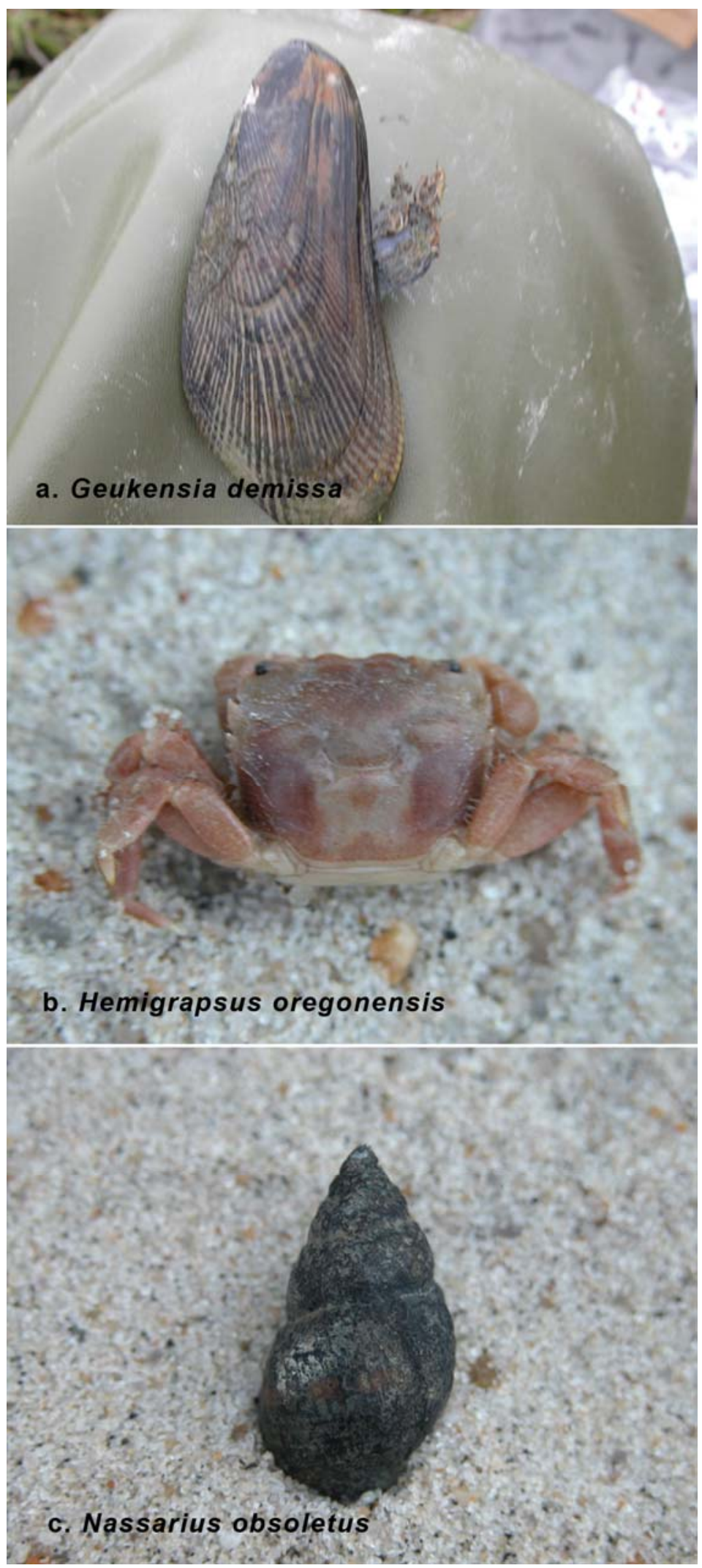

Figure 5-8. Invertebrate organisms collected at HAAF and China Camp. Mussels (a), crabs (b), and snails (c) 


\begin{tabular}{|c|c|c|c|c|c|c|c|}
\hline \multicolumn{8}{|c|}{$\begin{array}{l}\text { Table 5-5 } \\
\text { THg, MeHg, Percent MeHg and Bioaccumulation Factors (BAF) in Benthic Invertebrates } \\
\text { Collected at HAAF (SM-1, SM-10) and China Camp (R-44) Sites - June } 2003\end{array}$} \\
\hline Invertebrate & $\begin{array}{l}\text { THg, ng g } \\
\text { wet wt. }\end{array}$ & $\begin{array}{l}\begin{array}{l}\text { MeHg, ng g } \\
\text { wet wt. }\end{array} \\
\text { we }\end{array}$ & $\mathrm{MeHg}^{1}, \%$ & $\begin{array}{l}\begin{array}{l}\text { THg, } \text { ng g }^{-1} \\
\text { dry wt. }\end{array} \\
\end{array}$ & $\begin{array}{l}\begin{array}{l}\text { MeHg, } \text { ng g }^{-1} \\
\text { dry wt. }\end{array} \\
\end{array}$ & THg BAF $^{2}$ & $\begin{array}{l}\mathrm{MeHg} \\
\mathrm{BAF}^{2} \\
\end{array}$ \\
\hline \multicolumn{8}{|c|}{ SM-1 } \\
\hline Crab & $20.6(0.9)$ & $8.0(3.4)$ & $67.3(17.0)$ & $69.6(5.8)$ & $26.9(10.7)$ & $0.21(0.02)$ & $8.2(3.3)$ \\
\hline Mussel & $21.0(3.2)$ & $4.4(3.4)$ & $20.5(13.9)$ & $147(33)$ & $28.9(20.0)$ & $0.45(0.10)$ & $8.8(6.1)$ \\
\hline Snail & $100.9(16.6)$ & $39.5(8.7)$ & $39.9(11.0)$ & $401(128)$ & $153(35)$ & $1.2(0.4)$ & $46.0(10.8)$ \\
\hline \multicolumn{8}{|c|}{ SM-10 } \\
\hline Crab & $21.3(1.8)$ & $14.2(2.9)$ & $67.4(17.0)$ & $67.0(6.0)$ & $44.5(8.2)$ & $0.2(0.02)$ & $10.1(1.9)$ \\
\hline Mussel & $15.7(1.9)$ & $7.5(1.8)$ & $49.0(12.9)$ & $115(27)$ & $54.0(8.8)$ & $0.35(0.08)$ & $12.3(2.0)$ \\
\hline \multicolumn{8}{|c|}{$\mathrm{R}-44$} \\
\hline Crab & $18.1(5.2)$ & $3.9(32)$ & $19.9(10.3)$ & $56.0(12.7)$ & $11.8(8.6)$ & $0.18(0.04)$ & $3.3(2.4)$ \\
\hline Mussel & $29.3(5.7)$ & $16.0(9.4)$ & $53.8(30.9)$ & $187(43)$ & $105(67)$ & $0.58(0.13)$ & $29.2(18.6)$ \\
\hline
\end{tabular}

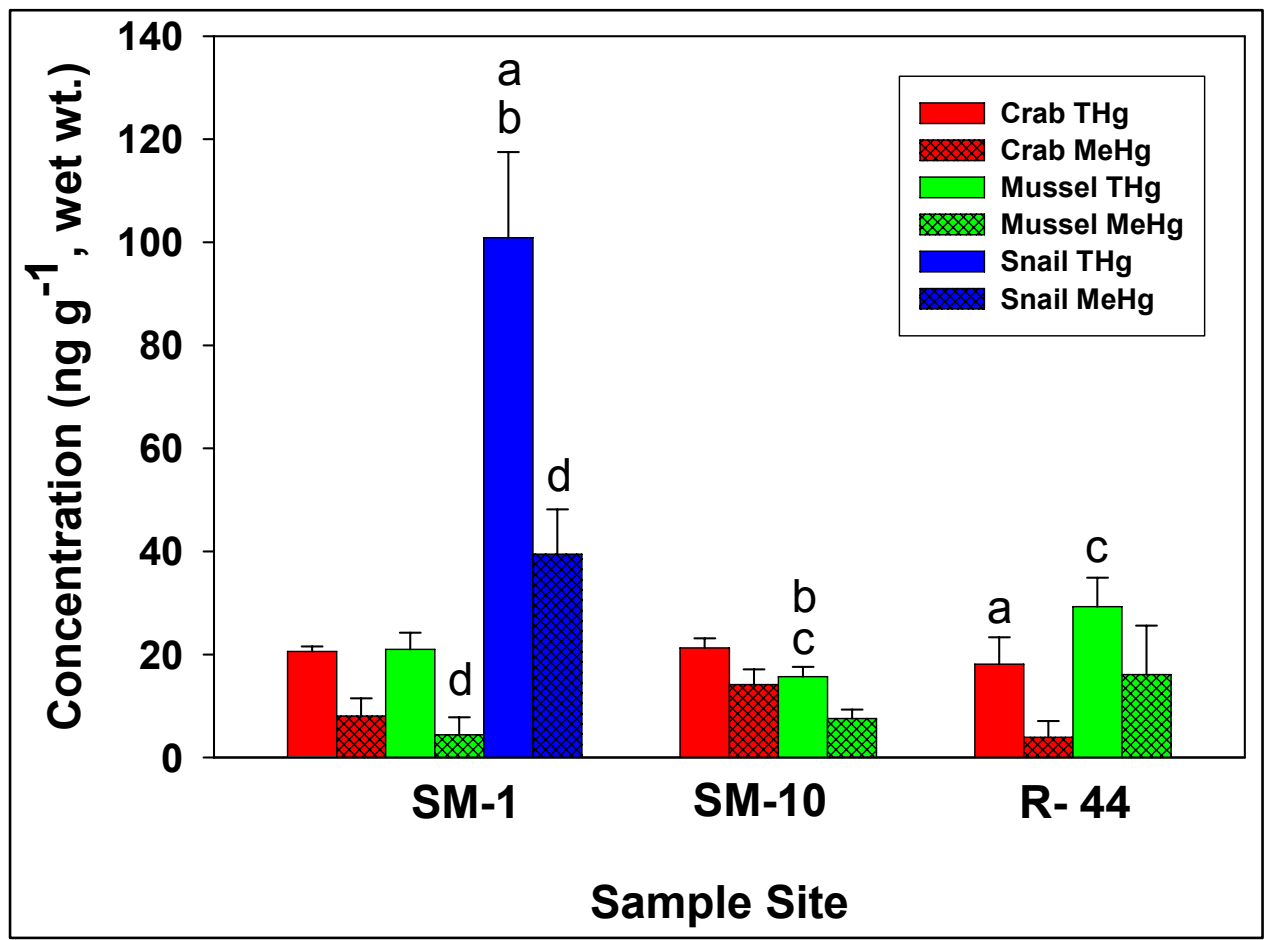

Figure 5-9. Tissue concentrations of $\mathrm{THg}$ and $\mathrm{MeHg}$ in invertebrates collected at HAAF (SM-1, SM-10) and China Camp (R-44). Mean values and SD $(\mathrm{N}=5)$. Matched letters indicate results were significantly different by Kruskal-Wallis one-way ANOVA on Ranks with Dunn's post hoc test $(P<0.05)$

$\mathrm{THg}$ and $\mathrm{MeHg}$ tissue/sediment bioaccumulation factors (BAF) were calculated as the ratio of dry weight tissue concentrations (Table 5-5; Figure 5-10) divided by dry weight sediment concentrations at the surface $(0$ to $2.5 \mathrm{~cm})$ for 
THg or MeHg at a given site (Table 5-2). Macrofauna and sediments were collected during the same time period (9-12 June 2003). BAFs for $\mathrm{MeHg}$ were highest with snails (BAF $=47.0$; Table 5-5) and were statistically greater than crabs from R-44 (Figure 5-10). BAF values greater than 1 generally indicate a tendency towards bioaccumulation, and all $\mathrm{MeHg}$ BAFs were greater than 1 (lowest MeHg BAF was 3.3; Table 5-5) indicating an elevated bioaccumulation potential for $\mathrm{MeHg}$ in invertebrates at $\mathrm{HAAF}$ and China Camp. BAFs for $\mathrm{THg}$ were highest for SM-1 snails (1.2; Table 5-5) and were statistically greater than in mussels from SM-10 and crabs from R-44 (Figure 5-10). The THg BAF for snails exceeded 1 , but this is probably due to the fact that approximately 40 percent of $\mathrm{THg}$ was actually $\mathrm{MeHg}$ (Table 5-5). In fact, if $\mathrm{MeHg}$ is factored out, the THg values for snail tissue [reduced by 40 percent from $401 \mathrm{ng} \mathrm{g}^{-1}$ (Table 5-5) to $241 \mathrm{ng} \mathrm{g}^{-1}$ ] and sediment [reduced by 1 percent from $330 \mathrm{ng} \mathrm{g}^{-1}$ (Table 5-2) to $327 \mathrm{ng} \mathrm{g}^{-1}$ ], the BAF drops to 0.74 . Considering this and the fact that all other THg BAFs were less than 1, it is reasonable to conclude that $\mathrm{THg}$ (representing all detectable mercury species) was generally associated with the sediment and bioaccumulation potential for $\mathrm{THg}$, as a whole, is relatively low.

$\mathrm{THg}$ and $\mathrm{MeHg}$ levels for snails (SM-1) were about five times higher than crabs or mussels collected at all sites. The elevated BAFs for snails concurs with the observations of Gardner et al. (1978) who found concentrations of THg in salt marsh snails Littorina irrorata that formed the basis of BAFs as much as tenfold higher than those found in other invertebrates. Mussels are filter feeders and would be expected to absorb $\mathrm{THg}$ and $\mathrm{MeHg}$ associated with suspended particulate matter in bay water. Crabs are omnivores, feeding on detritus of plant and/or animal origin. Snails feed largely on plant tissue, and since tissue levels and BAFs were significantly elevated for both $\mathrm{THg}$ and $\mathrm{MeHg}$ in snails, it may be that plants represent an important source of $\mathrm{MeHg}$ for terrestrial trophic transfer pathways. Furthermore, since plants comprise the majority of biomass at HAAF and China Camp, their total contribution to $\mathrm{MeHg}$ input for the local ecosystem could be significant. Additionally, plant detritus washed into the bay with the change in tides could be an important source of MeHg input for the San Pablo Bay ecosystem.

This work raises several important questions to be addressed in the near future. Are MeHg profiles (and related parameters) similar in other topographically distinct areas (mudflats, upland areas, etc.)? What are the impacts of seasonal variability on $\mathrm{MeHg}$ profiles? Is $\mathrm{MeHg}$ in surface sediment or detritus mobile with respect to tidal flux or storm runoff? Is there a net loss of $\mathrm{Hg}$ from HAAF sediments to the surrounding environment? If plants are a major component of $\mathrm{MeHg}$ trophic transfer pathways at HAAF, can the critical variables controlling the magnitude of their impact be identified and managed? 


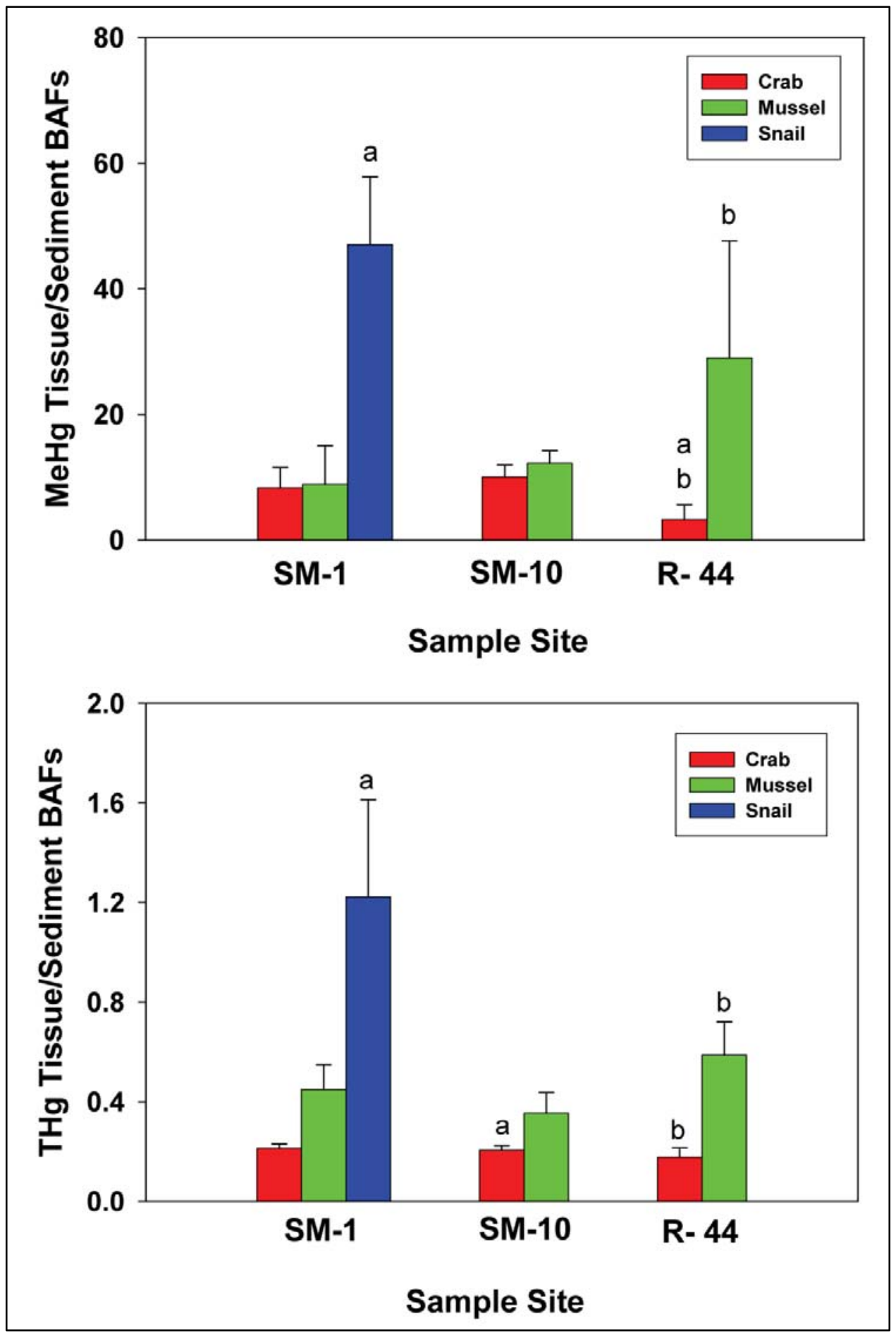

Figure 5-10. Bioaccumulation factors (BAFs) for $\mathrm{MeHg}$ (upper) and $\mathrm{THg}$ (lower) in invertebrates collected at HAAF (SM-1, SM-10) and China Camp ( $\mathrm{R}-44)$. Mean values and SD ( $\mathrm{N}=5)$. Matched letters indicate results were significantly different by Kruskal-Wallis one-way ANOVA on Ranks with Dunn's post hoc test $(P<0.05)$ 


\section{Bioavailability of Mercury to Benthic Invertebrates: Characterization and Remediation Effects in HAAF Wetland Sediments ${ }^{1}$}

\section{Summary}

Many studies have identified the potential adverse effects of bioaccumulation and biomagnification of $\mathrm{Hg}$. As such, it is imperative that the bioavailability of $\mathrm{Hg}$, and in particular the $\mathrm{MeHg}$ species, be ascertained as part of any assessment of environmental and human risk. The study incorporated two research goals, (1) to establish baseline bioaccumulation of $\mathrm{Hg}$ and $\mathrm{MeHg}$ in a representative and locally abundant benthic organism, the bent-nosed clam Macoma nasuta, and (2) whether $\mathrm{Hg}$ uptake might be reduced by the addition of $\mathrm{Hg}$-sorbing materials into the sediment. In the bioaccumulation experiment the uptake and elimination of THg and $\mathrm{MeHg}$ were measured in M. nasuta exposed to HAAF Bay Edge (SM-1 and SM-10) and the reference site China Camp State Park (R44) cores. A similar pattern of $\mathrm{THg}$ temporal bioaccumulation and similar final $\mathrm{THg}$ body burden at termination of the uptake phase of the experiment suggest that the bioavailability of $\mathrm{THg}$ was similar at all sites. The uptake phase was characterized by a rapid increase in body burden followed by a slower increase, whereas during the elimination phase a rapid decrease in body burden was followed by a slower decrease. Overall, the bioaccumulation study indicated that the elimination of $\mathrm{Hg}$ is very slow in benthic clams, as the apparent steady-state body burden was not reached following a 56-day exposure. The body burdens of the experimentally exposed clams were only approximately half of those recorded in clams inhabiting Bay Edge sediments, further suggesting that exposure periods longer than 56 days are needed for $\mathrm{THg}$ to approach apparent steady-state in clam tissues. The tissue $\mathrm{MeHg}$ concentrations varied considerably between replicates throughout the exposure, hampering the observation of

\footnotetext{
${ }^{1}$ Point of contact for this chapter is Guilherme Lotufo, U.S. Army Engineer Research and Development Center, Environmental Laboratory, Vicksburg, Mississippi, USA, Phone: 601-634-4103, Email: guilherme.lotufo@erdc.usace.army.mil
} 
temporal changes in body burden during the uptake and elimination phases of the bioaccumulation experiment.

In the remediation study, sediment from the SM-10 site was used to test the effects of granular activated carbon (GAC) and sulfonated Kraft lignin on speciation and bioaccumulation of $\mathrm{THg}$ and $\mathrm{MeHg}$ in 56-day exposures using $M$. nasuta. Results were mixed but promising. GAC significantly decreased the bioaccumulation of spiked $\mathrm{MeHg}$, and $\mathrm{MeHg}$ methylated from spiked $\mathrm{Hg}^{2+}$, despite the higher concentration of those substances in the amended sediment, whereas GAC did not affect the bioaccumulation of legacy $\mathrm{Me}^{202} \mathrm{Hg}$. It is suggested that GAC was more effective in reducing the uptake of spiked $\mathrm{Hg}$ species, since these were more labile and hence were freer to associate with GAC particles. In contrast, ambient $\mathrm{Hg}$ is more likely to be in closer association with sediment ligands, and hence would be more refractile and less available for contact with GAC. It is suggested that further experiments should contact sediment with GAC for periods longer than 16 days, to address efficacy of GAC on ambient $\mathrm{Hg}$ availability. Sulfonated Kraft lignin was extremely soluble in seawater, suggesting a short theoretical contact time with $\mathrm{Hg}$ in the sediments and raising issues of transportation of any lignin-sorbed $\mathrm{Hg}$ out of the system. Therefore, lignin was eliminated as a viable sorption candidate.

\section{Introduction}

$\mathrm{Hg}$ is one of the most studied trace elements, due to its high toxicity to both humans and animals, its association with historical and recent anthropogenic activities, and its disposition for biomagnification in food webs as $\mathrm{MeHg}$ (Chan et al. 2003). Hg contamination has been recognized as a serious problem in San Francisco Bay for many years, predominantly as a result of gold and silver mining activities in the coastal mountain ranges since the mid 1800s (Alpers and Hunerlach 2000).

Many studies have identified the potential for bioaccumulation of $\mathrm{Hg}$, and that the retention of $\mathrm{MeHg}$ within organism tissue and high trophic transfer efficiency results in significant potential for $\mathrm{Hg}$ biomagnification within food webs. As such, it is imperative that the bioavailability of $\mathrm{Hg}$, and in particular the $\mathrm{MeHg}$ species, be ascertained as part of characterization of $\mathrm{Hg}$ risk assessment. This study investigated the bioaccumulation of $\mathrm{Hg}$ and $\mathrm{MeHg}$ in a representative and locally abundant benthic organism, the bent-nosed clam Macoma nasuta.

In addition, this study addressed whether $\mathrm{Hg}$ and $\mathrm{MeHg}$ bioavailability might be reduced by the addition of $\mathrm{Hg}$-sorbing material. Recent studies have demonstrated that low-density carbonaceous particles can reduce contaminant aqueous availability in sediments (e.g. Zimmerman et al. 2004, Millward et al. 2004). In addition, activated carbon has been shown to be an effective sorbent of $\mathrm{Hg}$ in the elemental (USEPA 1997), ionic (Calgon Corp. unpubl.), and methyl forms. ${ }^{1}$ Sulfonated Kraft lignin is a byproduct of the paper industry, characterized by a high density of Hg-reactive sulfur groups, suggesting potential for

\footnotetext{
${ }^{1}$ Personal communication, V. S. Magar, Battelle Memorial Institute, Columbus, OH.
} 
sorption of ionic $\mathrm{Hg}$. Addition of such materials reduces the bioavailability of $\mathrm{Hg}$ to $M$. nasuta due to the repartitioning of $\mathrm{Hg}$ species onto these strong sorbents from more labile phases.

\section{Objectives}

The objectives of this study were to (1) describe the bioaccumulation of $\mathrm{Hg}$ to a representative sediment-dwelling intertidal invertebrate, and (2) explore the utility of $\mathrm{Hg}$-sorbent addition as an in situ remediation technique.

\section{Approach}

In the bioaccumulation experiment, the uptake and elimination of $\mathrm{THg}$ and $\mathrm{MeHg}$ were measured in the sediment-dwelling bivalve Macoma nasuta to establish site-specific patterns of bioaccumulation of those contaminants. In the remediation experiment, the efficacies of two potential sorbents, GAC and sulfonated Kraft lignin, in reducing the bioavailability of $\mathrm{THg}$ and $\mathrm{MeHg}$ to $M$. nasuta were tested. The latter experiment was expected to provide baseline information for potential $\mathrm{THg}$ and $\mathrm{MeHg}$ remediation strategies for HAAF sediments.

\section{Study site}

Sediment samples were collected from three tidal wetland sites: two locations at the HAAF Bay Edge (SM-1 and SM-10), with a high potential for $\mathrm{Hg}$ methylation, and one reference location at the China Camp State Park (R44; McFarland et al. 2002; Chapters 3 and 5 of this report).

\section{Sample collection}

Sediment samples were collected on 10-12 July 2003. Methods for the collection, transportation, and storage of sediments for both studies were designed to prevent the methylation of $\mathrm{Hg}$ in the sediment prior to the initiation of the experiment (Ullrich et al. 2001). For the bioaccumulation experiment, sediment cores (10.2-cm diameter, $20.3-\mathrm{cm}$ height) were collected at the three field sites using schedule 40 PVC piping. Twenty-four cores containing undisturbed surficial sediment were taken from each sampling location. Sediment cores were capped immediately, flash-frozen, packed with dry ice, and transported to Vicksburg, MS. Sediment cores were stored at $4{ }^{\circ} \mathrm{C}$ for $<4$ days before use. For the remediation experiment, surficial sediments were collected in 4-L buckets from site SM-10 only. 


\section{Experimental organism}

The estuarine, sediment-dwelling clam, Macoma nasuta, was used in all experiments. This bivalve inhabits shallow mud to muddy-sand substrates and occurs from Alaska to Southern California. The species has been recorded from the San Francisco Bay sediments, and fills a niche similar to that of M. balthica, a clam common in the intertidal sediments in San Pablo Bay. Macoma nasuta is a facultative deposit feeder, capable of suspension filter feeding and selective deposit feeding, and typically burrows down to a depth of $15 \mathrm{~cm}$. Its siphons are separated: the inhalant siphon takes up detritus and organic matter directly from either the overlying water or from the substrate, whereas the exhalant siphon deposits the indigestible particles and sediment on the sediment surface. The clams were purchased from a commercial vendor (Aquatic Research Organisms, Hampton, NH), who collected them from an unknown location and shipped them overnight to the Environmental Laboratory in Vicksburg, MS. Upon arrival, clams were acclimated to $15{ }^{\circ} \mathrm{C}$ in 25 -percent artificial seawater over a period of 2 to $3 \mathrm{hr}$.

\section{Sediment exposures}

The bioavailability of $\mathrm{Hg}$ and the effects of remediation strategies upon bioavailability were assessed by measuring bioaccumulation and kinetics of $\mathrm{THg}$ and $\mathrm{MeHg}$ in M. nasuta using methods based on standard bioaccumulation test protocols (USEPA 1989).

\section{Bioaccumulation experiment}

The uptake and elimination of $\mathrm{THg}$ and $\mathrm{MeHg}$ were investigated in M. nasuta exposed to intact sediment cores collected from the SM-1, SM-10, and China Camp R-44 sites. Time-series-sediment exposures were conducted using HAAF sediments from the three locations to establish site-specific patterns of bioaccumulation. Each core was submerged in an upright position in one 4-L plastic container containing 25-percent artificial seawater (2:3 ratio mixture of Forty Fathoms Crystal Sea ${ }^{\circledR}$, Baltimore, MD, and Instant Ocean $\left.{ }^{\circledR}, \mathrm{OH}\right)$, on 16 June, i.e., 5 to 6 days following sediment collection. Cores were maintained at $15^{\circ} \mathrm{C}$ in a temperature-controlled water bath under constant aeration using air stones. Five clams were sampled for tissue analysis prior to use in the experiment (day 0 ). After $48 \mathrm{hr}$, one clam was added to each core. The water in each container was renewed three times weekly and no supplemental food source was provided. To determine the uptake rate, clams were sampled after 2, 7, 14, 28, and 56 days of exposure, with three replicates per time point. At day 56, the remaining clams were transferred to approximately $300 \mathrm{~g} \mathrm{WW}$ of laboratory-control sediment from Sequim Bay, WA (pre-sieved to $<0.3 \mathrm{~mm}, 57 \pm 1 \mathrm{ng} \mathrm{g}^{-1} \mathrm{DW} \mathrm{THg}$ ), in 1-L beakers. Clams were sampled after 7, 14, and 28 days of exposure to control sediment to determine elimination rates. Tissues were removed from the clam shells, rinsed, blotted dry, wet weighed, and stored at $-80^{\circ} \mathrm{C}$ for subsequent chemical analysis. Sediment samples were taken from the top $2 \mathrm{~cm}$ of three replicate exposure beakers for each sediment treatment at experiment initiation, and 
analyzed for $\mathrm{THg}$, MeHg, total organic carbon (TOC), acid-volatile sulfide (AVS), and simultaneously extractable metals.

\section{Remediation of $\mathrm{Hg}$ bioavailability experiment}

Sediment from the SM-10 site was used to test the effects of GAC and sulfonated Kraft lignin on speciation and bioaccumulation of THg and $\mathrm{MeHg}$, using methods derived from similar sorbent remediation trials (Zimmerman et. al. 2004, Millward et. al. 2004). GAC is a heat-activated carbon substrate of both high surface area and high affinity for non-polar and ionic compounds, and has been suggested as a viable sorbent for the removal of contaminants from gaseous, aqueous, and sediment phases (Millward et al. 2004). GAC has a proven ability as a sorbent for $\mathrm{Hg}$ in the elemental (USEPA 1997), ionic (Calgon Carbon Corp., Pittsburgh, PA., unpubl.), and methyl forms. ${ }^{1}$

The addition of a sorbent as an in situ treatment for contaminated sediments is under evaluation in laboratory and field trials, both as an introduced additive and as part of an active cap (Zimmerman et al. 2004, Millward et al. 2004, personal communication V. S. Magar ${ }^{1}$ ). The addition of sorbent materials is expected to repartition the contaminants from the sediment and pore water phases onto the more strongly binding sorbent matrix, thereby reducing the availability flux into pore water and bioaccumulation into organisms. Experimental trials conducted at ERDC in collaboration with Stanford University have shown that GAC reduces $\mathrm{PCB}$ concentrations in pore water by 92 percent and $\mathrm{PCB}$ bioaccumulation by up to 87 percent after 6 months of contact (Millward et al. 2004). Other trials have shown that a GAC cap reduces flux of aqueous $\mathrm{MeHg}$ by 96 percent after 14 days. In addition, up to 58 percent of $\mathrm{MeHg}$ and 62 percent of $\mathrm{THg}$ can repartition from the sediment onto the sorbent after 4 months of contact. $^{2}$ These data suggest that GAC addition to contaminated sediments warrants consideration as a remediation strategy to reduce the availability of $\mathrm{Hg}$ for uptake into organisms and for methylation by microbes.

The surface sediments collected at HAAF site SM-10 were homogenized and sampled in triplicate for $\mathrm{THg}$ and $\mathrm{MeHg}$. Sediments were divided into three portions, one was amended with 3.4 percent (DW) GAC, one was amended with 3.4 percent (DW) sulfonated Kraft lignin, and the third portion served as an untreated control. After amendment, the sediments were mixed thoroughly with an impeller for approximately $4 \mathrm{hr}$, placed in sealed glass containers, and rolled at room temperature for 16 days. Sediments were then sampled for $\mathrm{THg}$ and MeHg. After sub-sampling, sediments were divided into seven replicate beakers, with approximately $150 \mathrm{~g}$ (DW) of sediment in each beaker. Replicates were covered with water (25-percent artificial seawater), aerated gently, and the sediments were allowed to settle for $24 \mathrm{hr}$. Adult M. nasuta (range 6.1 to $7.2 \mathrm{~g}$ whole WW) were added to each beaker, and were maintained at $15{ }^{\circ} \mathrm{C}$ for 56 days. Water was renewed three times a week, and no supplemental food was provided.

\footnotetext{
${ }^{1}$ Personal communication, V. S. Magar.

${ }^{2}$ Personal communication, V. S. Magar.
} 
In addition, the effects of GAC and lignin on the pool sizes of THg and $\mathrm{MeHg}$ were addressed. After sediment amendment and 16-day mixing, 500-g aliquots (DW) of each sediment were spiked with a cocktail of ${ }^{199} \mathrm{Hg}(\mathrm{II})$ : $\mathrm{Me}^{200} \mathrm{Hg}$ isotope cocktail, sufficient to add $15 \mathrm{ng} / \mathrm{g}{ }^{199} \mathrm{Hg}$ (II) and $150 \mathrm{pg} / \mathrm{g}$ $\mathrm{Me}^{200} \mathrm{Hg}$ (for details method, see Chapter 3 of this report). Sediment sub-samples were taken to determine the initial ${ }^{199} \mathrm{Hg}$ (II): methyl ${ }^{200} \mathrm{Hg}$ ratio and frozen at $-80{ }^{\circ} \mathrm{C}$ until further analysis. The remaining sediment was divided into three $1-\mathrm{L}$ beakers and used in the M. nasuta exposures described above. After 56 days, three animals were harvested from each treatment, and the tissue and sediment samples were frozen prior to analysis for $\mathrm{THg}, \mathrm{MeHg}$, and stable $\mathrm{Hg}$ isotopes. Results of the stable isotope experiment were used to quantify the impacts of GAC and lignin amendment on the bioaccumulation of ambient $\mathrm{Hg}$, ambient $\mathrm{MeHg}$, spiked $\mathrm{MeHg}$, and newly methylated $\mathrm{Hg}$.

\section{Chemical analyses}

Clam tissue and sediments were extracted and analyzed for THg using the USEPA Method 7471A cold-vapor technique (USEPA 1994). MeHg concentrations in sediment and tissue samples were determined using sample distillation and cold trapping prior to derivatization with sodium tetraethylborate. The volatile ethylated compound was then separated and detected by gas chromatography and atomic fluorescence (Demuth and Heumann 2001). MeHg determinations were performed under clean room conditions by the procedure described previously (McFarland et al. 2002). Total organic carbon content of sediments was measured using an Astro 2100 TOC analyzer (Zellweger Analytics, League City, TX). Acid-volatile sulfide (AVS) and simultaneously extractable metals were measured using the diffusion method of Leonard et al. (1996).

\section{Results and Discussion}

\section{Bioaccumulation experiment}

Sediment chemistry. Preliminary analyses of the intact sediment cores collected from SM-1, SM-10, and R-44 sites revealed that concentrations of THg, $\mathrm{MeHg}$, TOC, and simultaneously extractable metals were similar at the three sites (Table 6-1). However, concentrations of AVS in the top $2 \mathrm{~cm}$ at SM-1 and SM10 were low. In contrast, AVS was relatively high in the China Camp sediment and was in excess of the concentrations of simultaneously extractable metals and total inorganic $\mathrm{Hg}$, suggesting that most metals would be present as insoluble sulfides in reducing conditions. Bay Edge sediments offered a less sulfidic environment, probably due to the higher porosity of these sediments linked to the lower silt content (Chapter 5 of this report) and visually apparent deeper redox potential discontinuities compared to the China Camp sediment. The lower sediment sulfide concentrations at the Bay Edge sites would suggest only partial binding of metals into insoluble sulfides (although the extremely high affinity of $\mathrm{Hg}^{2+}$ for $\mathrm{S}^{2-}$ would lead to preferential $\mathrm{HgS}$ formation should any sulfide become present), suggesting that excess inorganic $\mathrm{Hg}$ at Bay Edge was available for methylation and bioaccumulation at the time of sampling. 
Bioaccumulation. Detectable levels of $\mathrm{THg}$ and $\mathrm{MeHg}$ were present in the clams before exposure ( $\mathrm{THg} 14 \mathrm{ng} \mathrm{g}^{-1}, \mathrm{MeHg} 8 \mathrm{ng} \mathrm{g}^{-1} \mathrm{WW}$ ). A similar pattern of $\mathrm{THg}$ temporal bioaccumulation and similar final $\mathrm{THg}$ body burden at termination of the uptake phase of the experiment (Figure 6-1) suggest that the bioavailability of THg was similar at all sites, despite the presence of excess sulfide measured at $\mathrm{R}-44$, but not at Bay Edge sites SM-1 and SM-10. It is concluded that any HgS formation at R-44 resulting from the reducing conditions at this site did not affect $\mathrm{Hg}$ bioavailability. Tissue $\mathrm{MeHg}$ concentrations varied considerably between replicates throughout the exposure ( 9 to $17 \mathrm{ng} \mathrm{g}^{-1}$ for SM-1, 13 to $18 \mathrm{ng} \mathrm{g}^{-1}$ for SM-10, and 13 to $21 \mathrm{ng} \mathrm{g}^{-1}$ for R-44, data are not shown) hampering the observation of temporal changes in body burden during the uptake and elimination phases of the bioaccumulation experiment.

\begin{tabular}{|c|c|c|c|c|c|c|c|c|c|}
\hline \multicolumn{10}{|c|}{ Table 6-1 } \\
\hline Site & $\begin{array}{l}\mathrm{Hg}, \\
\mathrm{ng} \mathrm{g}^{-1}\end{array}$ & $\begin{array}{l}\text { Methyl Hg, } \\
\text { ng g }^{-1}\end{array}$ & $\begin{array}{l}\text { AVS, } \\
\text { ng g }^{-1}\end{array}$ & $\begin{array}{l}\mathrm{SEM}_{\text {cu, }}, \\
\text { ng g }^{-1}\end{array}$ & $\begin{array}{l}\mathrm{SEM}_{\mathrm{p}}, \\
\mathrm{ng} \mathrm{g}^{-1}\end{array}$ & $\begin{array}{l}\text { SEM }_{\text {Cd }} \\
\text { ng g }^{-1}\end{array}$ & $\begin{array}{l}\mathrm{SEM}_{\mathrm{zn}}, \\
\mathrm{ng} \mathrm{g}^{-1}\end{array}$ & $\begin{array}{l}\mathrm{SEM}_{\mathrm{Ni}}, \\
\mathrm{ng} \mathrm{g}^{-1}\end{array}$ & $\begin{array}{l}\text { TOC, } \\
\%\end{array}$ \\
\hline SM-1 & 269 & 0.74 & 0 & 4497 & 109 & 18 & 990 & 368 & 1.4 \\
\hline SM-10 & 266 & 1.00 & 101 & 483 & 107 & 19 & 975 & 382 & 1.5 \\
\hline$R-44$ & 270 & 1.54 & 5099 & 441 & 100 & 19 & 900 & 307 & 1.6 \\
\hline
\end{tabular}

THg uptake and elimination kinetics did not conform to single-compartment kinetics at all sites. The uptake and elimination of THg appeared to be biphasic processes. The uptake process was characterized by a rapid ( $<7$ days) uptake phase to 14 to $18 \mathrm{ng} \mathrm{g}^{-1} \mathrm{WW}$ above background, followed by a slower uptake phase to 52 to $57 \mathrm{ng} \mathrm{g}^{-1} \mathrm{THg}$ above background. Similarly, elimination was characterized by a rapid (<14 days) loss of 29 to $33 \mathrm{ng} \mathrm{g}^{-1}$ of day 56 residues, followed by a slower elimination phase after day 14 . One plausible explanation for the rapid initial uptake (and elimination) is the ingestion (and egestion) of contaminated sediment. Simple calculations indicate that the initial rapid increase in body burden during the uptake phase could be explained by the ingestion of approximately $30 \mathrm{mg}$ DW sediment, and that the rapid decrease in body burden during the initial rapid elimination phase could be explained by the ingestion of approximately $60 \mathrm{mg}$ DW sediment. While no literature references were found illustrating Macoma gut volumes, it is plausible that the flux of ingested sediment accounts for the rapid "uptake" and "elimination" phases of THg accumulated. Uncertainty regarding the impact of ingested material on body burden analyses prevents us from establishing uptake and elimination kinetics. Nevertheless, the bioaccumulation data indicated that the elimination of $\mathrm{Hg}$ is very slow in these organisms, as the apparent steady-state body burden was not reached following a 56-day exposure. The final body burdens of the experimentally exposed clams were only 55-59 percent of those recorded in Modiolus sp. clams collected at a range of sites at Hamilton in 2001 (McFarland et al. 2002), further suggesting that long exposure periods are needed for $\mathrm{THg}$ to approach apparent steady state in this species. 


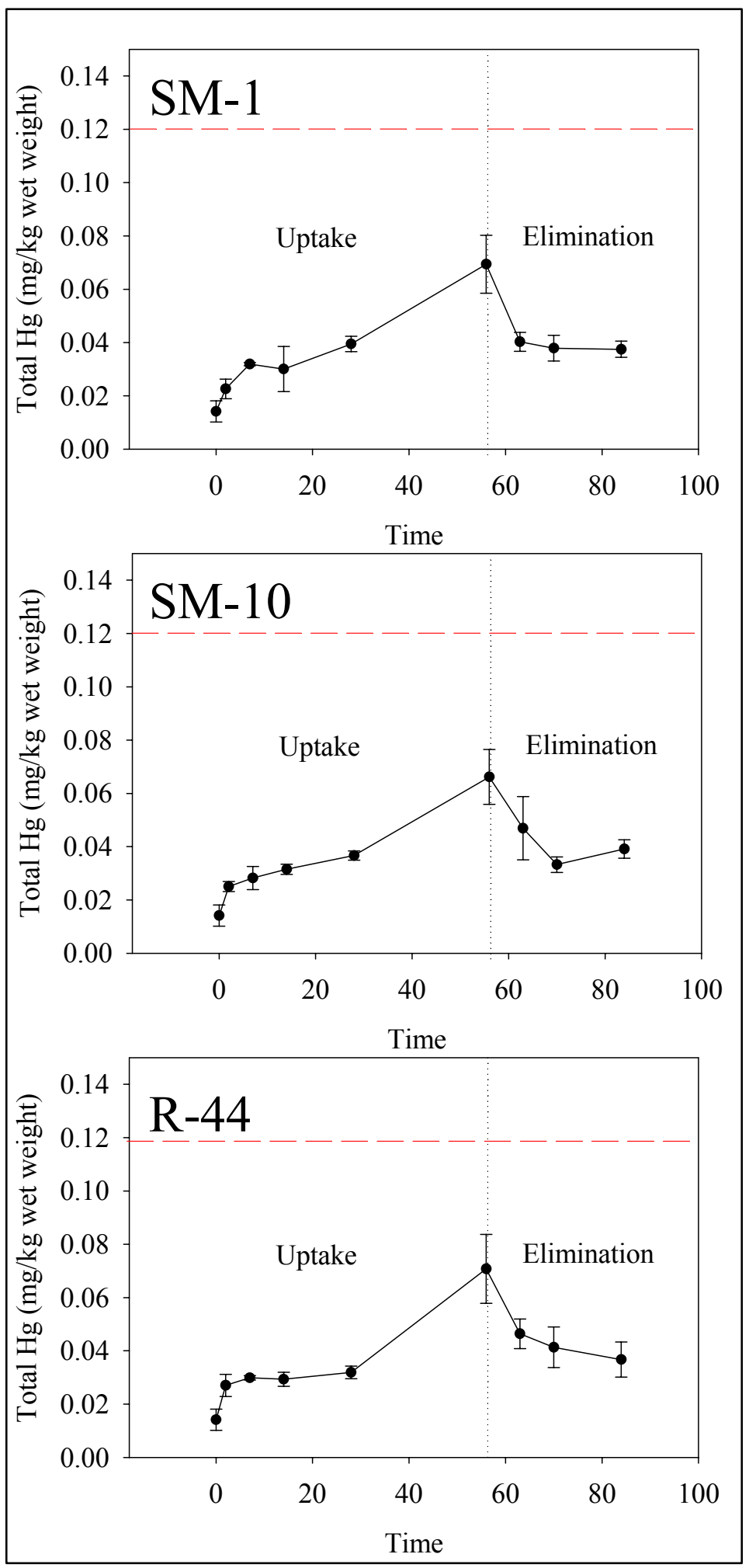

Figure 6-1. Uptake and elimination of THg from Macoma nasuta exposed to SM-1, SM-10, and R-44 sediments. Dashed line indicates the body burden in field-collected Modiolus sp. $\left(0.12 \mathrm{ng} \mathrm{kg}^{-1}\right.$, McFarland et al. 2002) 


\section{Remediation of Hg bioavailability experiment}

Effect of GAC and lignin on sediment MeHg. The addition of GAC did not affect the THg concentration in sediment, as expected (Figure 6-2). However, ambient $\mathrm{MeHg}$ concentration in the sediment was substantially higher in the GAC-amended treatment $\left(1.34 \pm 0.07 \mathrm{ng} \mathrm{g}^{-1}\right)$ compared to the non-amended treatment $\left(0.85 \pm 0.04 \mathrm{ng} \mathrm{g}^{-1}\right)$ (Figure 6-2). The concentration of spiked $\mathrm{MeHg}$ $\left(\mathrm{Me}^{200} \mathrm{Hg}\right.$ and $\mathrm{Me}{ }^{199} \mathrm{Hg}$ ) was also higher in GAC-treated sediments (Figure 6-2). Presently this increase cannot be explained, but this phenomenon will be monitored in future studies.

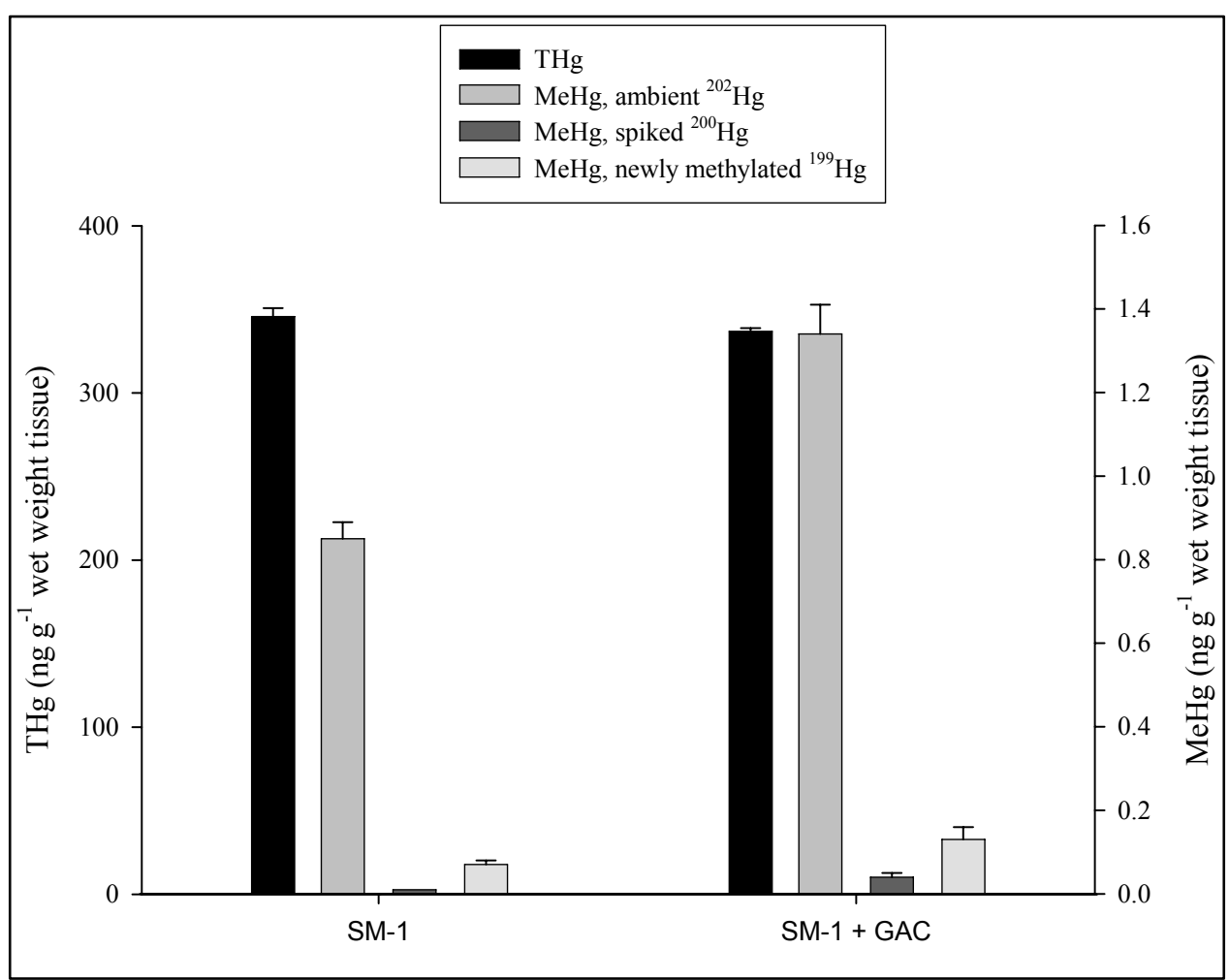

Figure 6-2. Effect of granular activated carbon on sediment pool sizes of legacy ${ }^{202} \mathrm{Hg}$, spikes $\mathrm{Me}^{200} \mathrm{Hg}$, and newly methylated ${ }^{199} \mathrm{Hg}$

The addition of GAC did not significantly affect the bioaccumulation of legacy $\mathrm{Me}^{202} \mathrm{Hg}$ in this experiment (Figure 6-3). However, as noted above, the legacy $\mathrm{Me}^{202} \mathrm{Hg}$ concentration was elevated in the GAC treatment, resulting in higher $\mathrm{MeHg}$ exposure. Biota accumulation factors (BAF, concentration of a substance in an aquatic organism divided by the concentration of the substance in the sediment) were determined to quantify $\mathrm{Hg}$ and $\mathrm{MeHg}$ bioavailability in the laboratory exposures. The $\mathrm{Me}^{202} \mathrm{Hg}$ BAF for the GAC treatment was 46 percent lower than that for the untreated sediment (Figure 6-4) indicating a decrease in the bioavailability of ambient $\mathrm{MeHg} \mathrm{BAF}$ in the presence of GAC. 


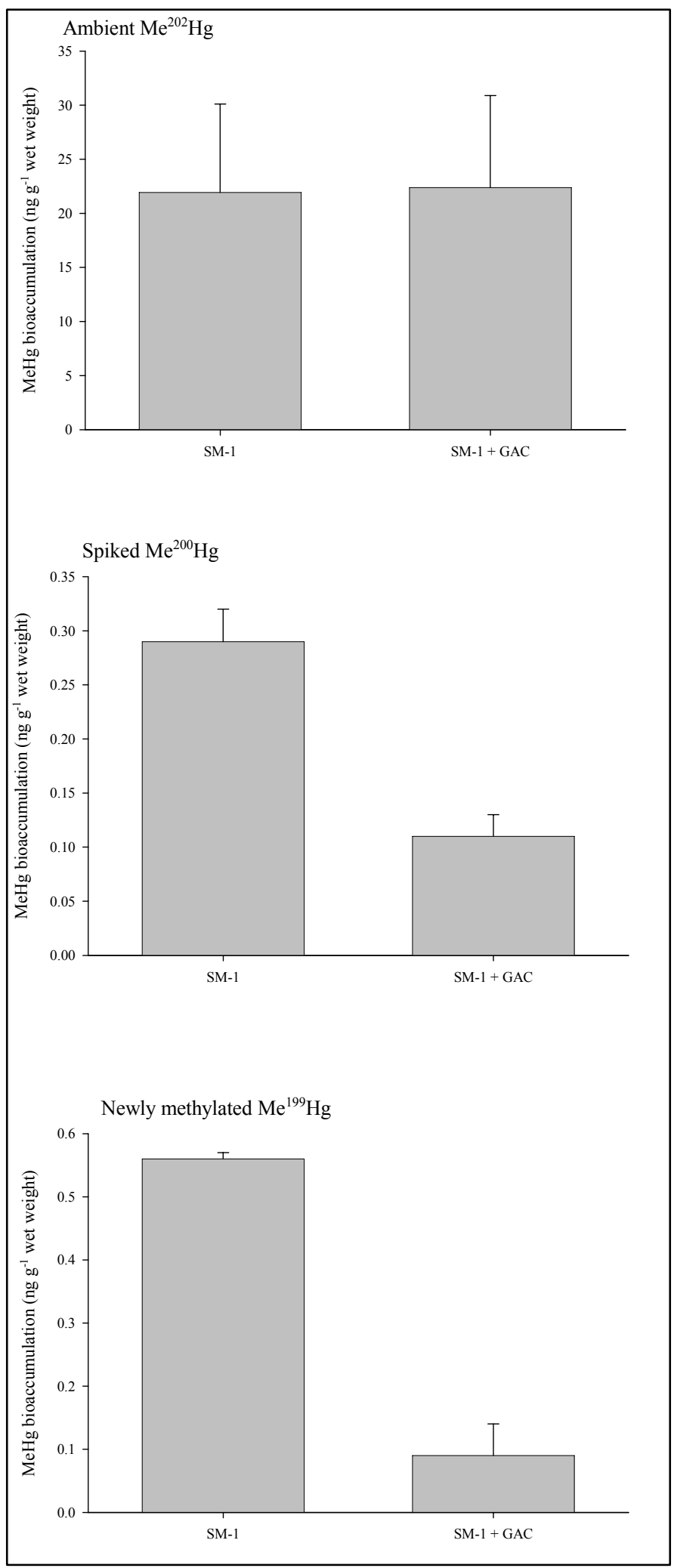

Figure 6-3. Effect of granular activated carbon on bioaccumulation of legacy ${ }^{202} \mathrm{Hg}$, spiked $\mathrm{Me}^{200} \mathrm{Hg}$, and newly methylated ${ }^{199} \mathrm{Hg}$ 


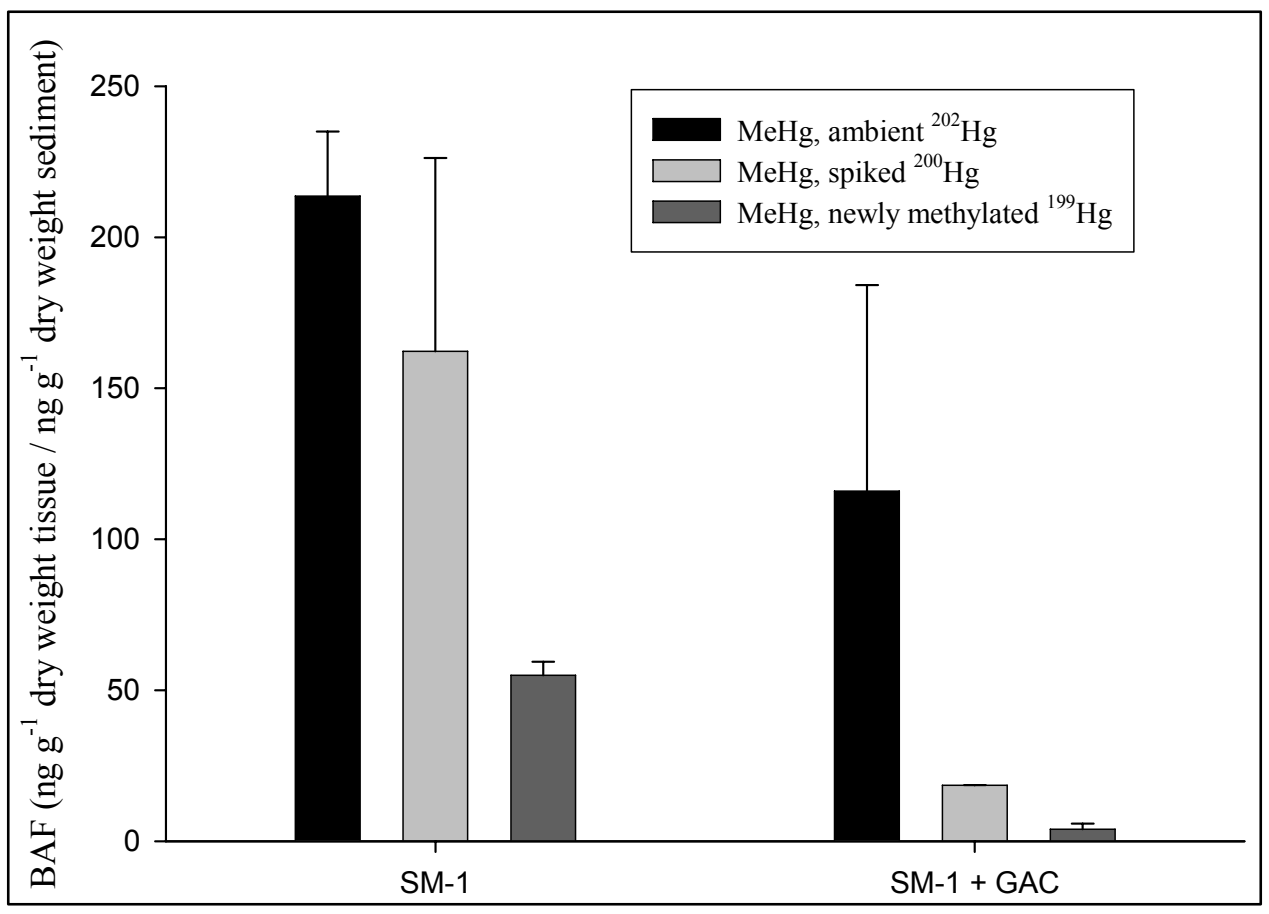

Figure 6-4. Effect of granular activated carbon on biota accumulation factor (BAF) for legacy ${ }^{202} \mathrm{Hg}$, spiked $\mathrm{Me}^{200} \mathrm{Hg}$, and newly methylated ${ }^{199} \mathrm{Hg}$

The presence of GAC decreased the bioaccumulation of $\mathrm{Me}^{200} \mathrm{Hg}$ by 63 percent and of $\mathrm{Me}^{199} \mathrm{Hg}$ by 85 percent, despite the increased concentration of $\mathrm{MeHg}$ in GAC-amended treatments. Therefore, the addition of GAC followed by a 16day contact period caused decreases in bioaccumulation from the more labile $\mathrm{Hg}$ pools, added as a $\mathrm{Me}^{200} \mathrm{Hg}$ spike and newly methylated from the ${ }^{199} \mathrm{Hg}$ spike by an order of magnitude. GAC reduced the $\mathrm{Me}^{200} \mathrm{Hg}$ BAF by 89 percent and $\mathrm{Me}^{199} \mathrm{Hg}$ BAF by 93 percent demonstrating substantial effectiveness of GAC in reducing the bioavailability of spiked or newly formed $\mathrm{MeHg}$. GAC was less effective in reducing the bioavailability of legacy $\mathrm{Me}^{202} \mathrm{Hg}$, as the corresponding BAF was reduced by only 46 percent.

Results from this study agree with results obtained from previous work with the effects of GAC on fate of $\mathrm{MeHg}^{1}$ reporting that the effects of GAC emerged far more rapidly for the more labile aqueous phase than for the more recalcitrant, sediment-associated MeHg. This is almost certainly due to the slow and partial release of $\mathrm{MeHg}$ from a solid into the dissolved phase, from where it is available for repartitioning onto the sorbent active surface. Such desorption rate limiting processes have been observed in sorbent studies with PCB-contaminated sediments (Millward et al. 2004, Zimmerman et al. 2004). If this is the case, then contact periods longer than 16 days should be used to address the longer-term efficacy of GAC on legacy Hg availability.

Sulfonated Kraft lignin was extremely soluble in seawater, suggesting a short theoretical contact time with $\mathrm{Hg}$ in the sediments and raising issues of transportation of any lignin-sorbed $\mathrm{Hg}$ out of the system. Therefore, lignin was eliminated as a viable sorption candidate.

\footnotetext{
${ }^{1}$ Personal communication, V. S. Magar.
} 


\section{Integrating Physical,} Chemical, and Biological Processes that Drive Mercury and Methylmercury Cycling in
San Pablo Bay Salt
Marshes into a Screening-
Level Model ${ }^{1,2}$

\section{Summary}

The Questions and Decisions TM (QnD): screening model system was created to provide an effective tool to incorporate ecosystem and management issues into a user-friendly framework. The QnD model links the spatial components within GIS files to the prevalent abiotic, climatic, and biotic interactions in an ecosystem. QnD has a simple design and can be upgraded easily. This modeling approach has been applied to the HAAF wetland restoration project (QnD:HAAF). The purpose of the current QnD:HAAF version 1.0 is to integrate the field and laboratory data detailed in the preceding chapters of this report. QnD:HAAF is being applied in an iterative, interactive manner to identify critical abiotic and biotic drivers of salt marsh $\mathrm{Hg}$ and $\mathrm{MeHg}$ cycling and guide subsequent work on HAAF and San Francisco Bay salt marshes. It is planned to incorporate and link scientific, economic, and social issues in a manner that enables the evaluation of their relative impacts through scenario projections. As further learning occurs, those drivers that are shown to be important can be explored and subsequently expanded, and those judged unimportant can be discarded. Whereas

\footnotetext{
${ }^{1}$ Point of contact for this chapter is Elly P. H. Best, U.S. Army Engineer Research and Development Center, Environmental Laboratory, Vicksburg, Mississippi, USA, Phone: 601-634-4246, Email: elly.p.best@erdc.usace.army.mil.

${ }^{2}$ Supporting documentation for this chapter can be found in Appendix B.
} 
these changes would require substantial code rewriting of other models, they are rapidly made in QnD.

The QnD:HAAF v1.0 is composed by four spatial areas (High Salicorniavegetated Marsh, Mid Spartina-vegetated Marsh, Mud Flat, and Sub Tidal), three drivers (day-time light, dry and wet season, and tide-dependent redox potential), and two processes (methylation and demethylation). Biota are represented by typical plant and animal species.

Although QnD:HAAF v1.0 development is based only 10 percent on concepts and literature data, and 90 percent on data measured in one year only, i.e. 2003, the model results have generated several interesting points for discussion and further exploration.Two 14-day scenarios were simulated, i.e., one scenario representing the wet season (1-14 February 2004) and one scenario representing the dry season (1-14 June 2003). Simulated MeHg levels in biota indicated a significant bioaccumulation potential from lower to higher trophic levels, regardless of season. Elevation was an important factor influencing net $\mathrm{MeHg}$ production. Simulated MeHg concentrations in the sediment greatly exceeded the measured levels, whereas simulated methylation and demethylation rates were on the same order of magnitude as measured values. The difference between the simulated and measured $\mathrm{Hg}$ levels in the sediment and biota can provide a first estimate of the magnitude of the HAAF Hg export term. Current work plans focus on validating the value of the HAAF $\mathrm{Hg}$ export term and the processes by which this export is realized.

\section{Introduction}

Stakeholders involved in wetland restoration activities on the former Hamilton Army Air Field (HAAF) aim at restoring San Pablo Bay wetland habitat, while minimizing conditions for $\mathrm{MeHg}$ production and its subsequent trophic transfer to San Francisco Bay fisheries. However, sufficiently detailed information on environmental $\mathrm{Hg}$ levels at HAAF are lacking. That is, a mechanistic understanding is lacking of the factors that control these levels and the means to use this information in ecosystem models supporting environmental management decisions. This chapter outlines an approach that integrates information from the other four chapters of this report into a tool that directly links the environmental information in such a way that practical management decisions related to design, construction, and maintenance of coastal wetland areas can be based on the simulation results.

The Questions and Decisions ${ }^{\mathrm{TM}}(\mathrm{QnD})$ screening model system was created to provide an effective tool to incorporate ecosystem, management, economics, and socio-political issues into a user-friendly framework. The QnD model links the spatial components within geographic information system (GIS) files to the prevalent abiotic, climatic, and biotic interactions in an ecosystem. QnD has a simple design and can be upgraded easily. It facilitates the use of our developing dataset as a basis for screening-level predictions for (1) other coastal wetland sites, and (2) "scaling up" for landscape-scale simulations. QnD:HAAF is being applied in an iterative, interactive manner to identify critical abiotic and biotic 
drivers of salt marsh $\mathrm{Hg}$ and $\mathrm{MeHg}$ cycling and guide subsequent work on HAAF and San Francisco Bay salt marshes. Scientific, economic, and social issues will also be incorporated and linked in a manner that enables the evaluation of their relative impacts through scenario projections. As further learning occurs, those drivers that are shown to be important can be explored and subsequently expanded; those judged unimportant can be discarded. Whereas these major structural changes would require substantial code rewriting of other models (e.g., Mercury Cycling Model; Hudson et al. 1994), these changes are rapidly made in QnD. QnD achieves modeling nimbleness by keeping compartments, processes, and interactions conceptually simple. Thus, the QnD:HAAF system can serve as a "capstone" for integrating monitoring results into a more management-focused model.

The current version (v1.0) of QnD:HAAF is focused on exploring consensus technical questions formulated at the CALFED Stakeholders Workshop on Mercury in San Francisco Bay held 8-9 October 2002 at Moss Landing Marine Laboratories. These included:

a. What are the present levels of $\mathrm{MeHg}$ in SF Bay wetlands with respect to biota and sub-habitats, and location within the bay?

$b$. What are the rates of $\mathrm{MeHg}$ production?

c. What factors control MeHg production? Can these be managed?

d. Are some wetlands larger mercury exporters than others?

e. Can we model/predict the effects of wetland restoration on $\mathrm{MeHg}$ production and export?

\section{QnD:HAAF Model Description}

The various objects used in the initial version of QnD:HAAF are presented in Figure 7-1. These objects (chemicals, organisms, and drivers) exist within a "virtual" landscape of spatial areas and habitats. The chemical and organism objects participate in specific processes that cause changes in the ecosystem. For example: within a High Marsh (spatial area object), a crab (organism object) may take up $\mathrm{MeHg}$ from the sediment (chemical object). An extended description of the model, including the data with which it was calibrated originally, is presented in Appendix B.

\section{Four spatial areas}

Whereas QnD can simulate ecosystem components and processes for an entire map of linked spatial areas, the initial version of QnD:HAAF utilizes four stylized wetland areas (Figure 7-2). This spatial simplification allows the use of the data of initial feasibility studies with simplified modeling concepts, instead of attempting to fit a complex model to an ecosystem in which limited data have been collected. In QnD:HAAF, the selected scale of each spatial area is $10 \mathrm{~m} \times$ $10 \mathrm{~m}\left(100 \mathrm{~m}^{2}\right)$, all mass data are on a dry weight basis, and all simulated data are on a square meter basis. 


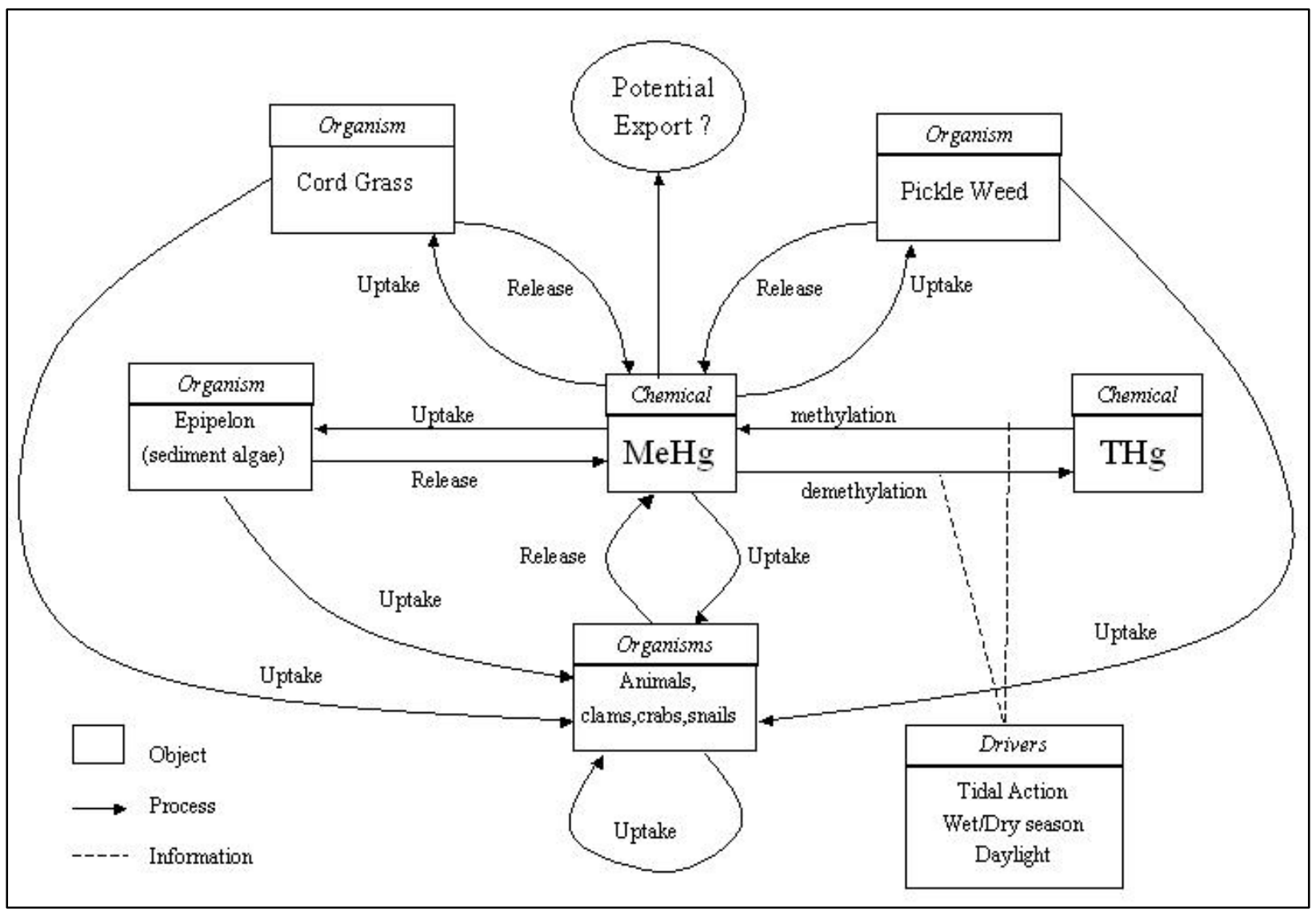

Figure 7-1. Overview of QnD:HAAF components, drivers, and processes

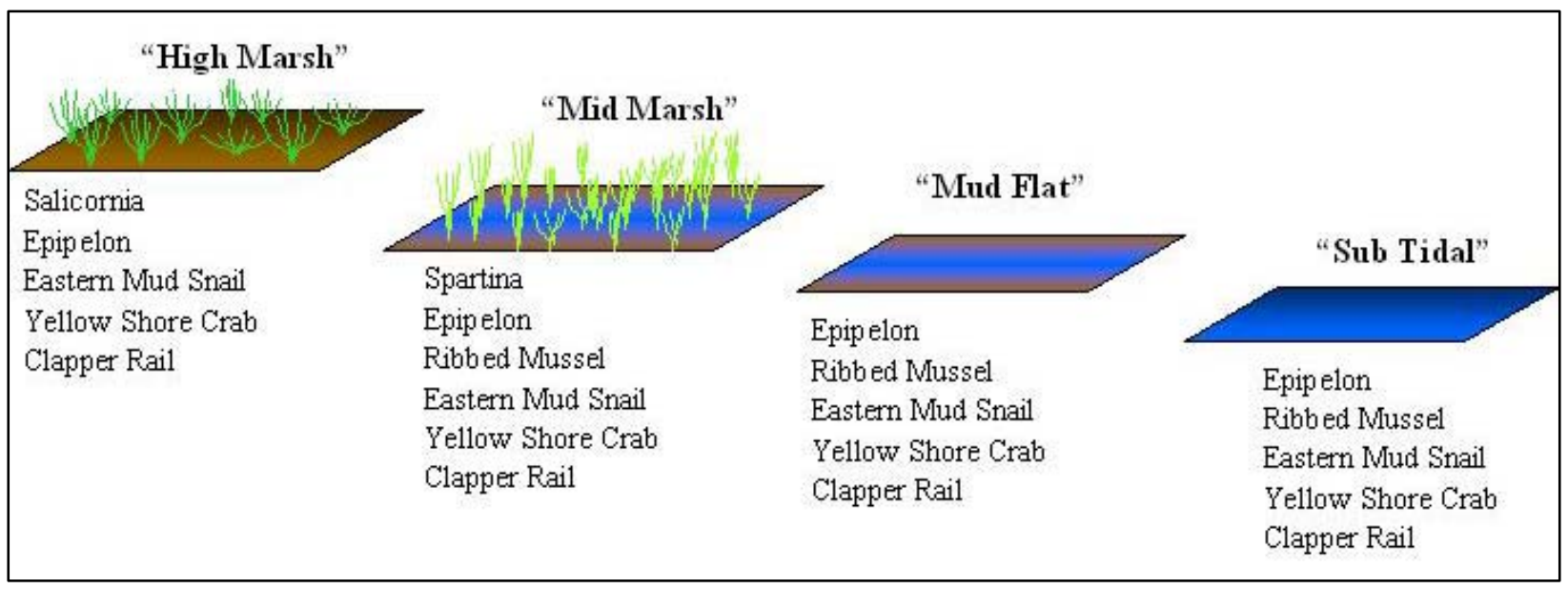

Figure 7-2. Spatial units and organisms within QnD:HAAF version 1.0

The "High Marsh" area represents Salicornia virginica (pickleweed)dominated areas that are rarely flooded. The "Mid Marsh" area represents Spartina foliosa (cord grass)-dominated areas that are partially flooded as a part of the daily tidal cycle. The third spatial area represents the "Mud Flat" zone that is partially submerged. The fourth spatial area represents the "SubTidal" zone that is completely submerged. The elevation of each spatial area is kept constant. 
High Marsh was kept at $3.0 \mathrm{ft}(1 \mathrm{~m})$ above Mean High Water (MHW), Mid Marsh at $1.0 \mathrm{ft}(0.333 \mathrm{~m})$, Mud Flat at $0.5 \mathrm{ft}(0.167 \mathrm{~m})$ and Sub Tidal at $-1.0 \mathrm{ft}$ $(-0.333 \mathrm{~m})$. Each spatial area has resident biota, as listed in Figure 7-2.

\section{Habitats}

Habitats exist within and occupy a fraction of each spatial area. The habitats are assumed to be homogeneous and harbor different combinations of biota and chemicals. In the initial version of QnD:HAAF, no specialized habitats within the spatial areas are distinguished, i.e. one "default" habitat occupies 100 percent of the spatial area. In upgrades, a plant- and a non-plant influenced habitat within each spatial area may be introduced. The latter upgrade would allow $\mathrm{QnD}$ to simulate the effects of depositing dredged material on a vegetated area. This management action may convert a portion of a vegetated wetland temporarily into a mud flat with altered $\mathrm{Hg}$ dynamics.

\section{Environmental drivers and time scales}

Three environmental drivers were selected to link processes at time scales varying from current (onsite measured methylation and demethylation rates in light versus in darkness, cf. Chapter 3 of this report) to seasonal (wet versus dry season data on $\mathrm{THg}$ and $\mathrm{MeHg}$ concentrations in the sediment, cf. MacFarland et al. 2003a, 2003b). An on-line tide simulator for the bay area provided initial estimates of tidal water levels for selected time periods on an hourly basis (http://tbone.biol.sc.edu/tide/sitesel.html). Values pertaining to the mouth of the Petaluma River were selected, since these were considered as representative for the nearby HAAF. In general, SI units are used. The only exception is water depth, where feet are used for easy import of water-level data from the on-line tide simulator.

For initial QnD:HAAF v1.0 testing, two hourly time series were constructed, representing a dry season, i.e. 1-14 June 2003, and a wet season, i.e., 1-14 February 2004), respectively. QnD:HAAF v1.0 utilizes a default time-step of $1 \mathrm{hr}$, and can model results and thus easily be converted into daily values by multiplication with a factor of 24 .

Tidal and redox processes. Water depth on each spatial area is calculated by subtracting its local elevation hourly from tidal water level. If the calculated local water depth has a positive sign, then the spatial area is considered as being submerged and susceptible to decreasing oxygen diffusion. Vice versa, if the calculated local water depth has a negative sign, then the spatial area is considered as extending above the water level and thus susceptible to oxygen diffusion from the ambient air. The cumulative numbers of hours under and above the water level, respectively, are used to calculate the hourly change in redox potential $(\mathrm{mV})$. The hourly change in redox potential is then added to the cumulative redox potential for each spatial zone. 


\section{Hg dynamics}

Two chemical $\mathrm{Hg}$ pools are assumed to exist and be available for transformation: $\mathrm{THg}$ and $\mathrm{MeHg}$ (Figure 7-1). Both pools are assumed to reside in the surficial 5-cm sediment layer and its associated pore water. The pools change in mass per unit area $\left(\mathrm{ng} \mathrm{m}^{-2}\right)$, but have an associated, calculated concentration (ng $\left.\mathrm{g}^{-1}\right)$. The pools are considered as fully active, i.e., the whole $\mathrm{THg}$ pool is available for conversion into the $\mathrm{MeHg}$ pool, and vice versa. $\mathrm{THg}$ is transformed into $\mathrm{MeHg}$ as a function of time of year (dry or wet season), redox potential (dependent on tidal movements), and time of day (light or dark conditions). The values assigned to the pools of mercury are defined by the analytical procedures used to measure $\mathrm{THg}$ and $\mathrm{MeHg}$. It is assumed that all $\mathrm{THg}$ and $\mathrm{MeHg}$ are reactive, but this is an overestimate since only a fraction may be reactive and/or is bioavailable. However, it is currently not known what and how large the reactive and bioavailable fractions are.

Mercury methylation. The methylation process is presented in Figure 7-3. In the model, methylation is affected by redox potential, tidal water movements, season, and light/dark conditions. The calculations of water depth and redox potential, prerequisites for the calculation of methylation, have been described in Appendix B.

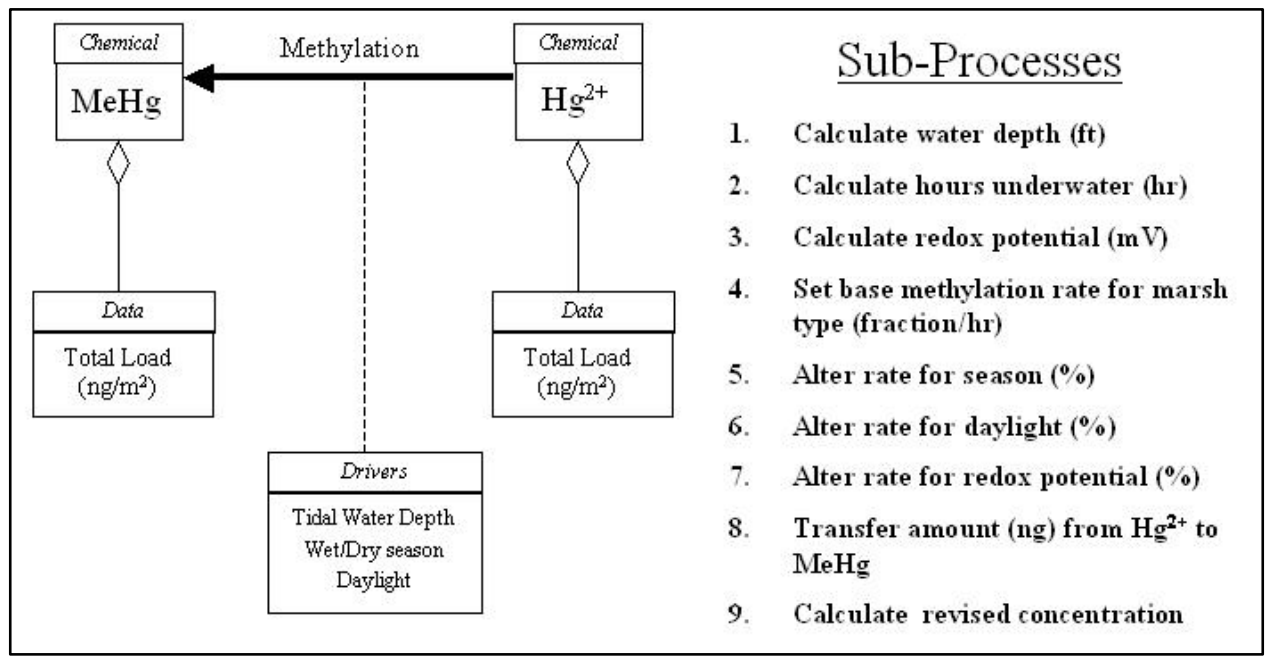

Figure 7-3. Overview of the QnD:HAAF Hg methylation process

The base $\mathrm{THg}$ methylation rates have been derived from the rates measured in the field in 2003, under dry season, daylight, and aerobic conditions (Chapter 3 of this report). A description of the effects of season, daylight, and redox potential on methylation is given in Appendix B. In the current overview of the model, the equations have been assigned the same numbers as in Appendix B.

In the model, the amount of $\mathrm{Hg}$ methylated hourly in each spatial area is calculated as a percentage of the total available, inorganic $\mathrm{Hg}^{2+}$ pool (TotalHg), as follows: 


$$
\operatorname{MeHg}_{n}=\left(\begin{array}{c}
\text { BaseRate }_{\text {meth }} \times \operatorname{Season}(\text { month }) \times \operatorname{Re} \text { dox }_{m}(\text { hours }) \\
\times \text { Light }_{m}(\text { daylight }) \times \text { TotalHg }^{\prime}
\end{array}\right)
$$

where

BaseRate $_{\text {meth }}=\mathrm{THg}$ methylation (ng MeHg methylated $\mathrm{ng}^{-1} \mathrm{Hg}^{2+} \mathrm{hr}^{-1}$ )

Season $($ month $)=$ seasonal, month-specific, effect on methylation rate (-)

$\operatorname{Redox}_{\mathrm{m}}($ hours $)=$ redox potential effect on methylation rate, depending on the cumulative number of hours under water or extending above the water level (-)

$\operatorname{Light}_{m}($ daylight $)=$ daylight effect on methylation rate depending on time of day $(-)$

$$
\text { TotalHg }=\text { size } \mathrm{Hg}^{2+} \text { pool (ng DW) }
$$

MeHg demethylation. The demethylation process is represented in Figure 7-4. $\mathrm{MeHg}$ is demethylated and returns as $\mathrm{Hg}$ to the active $\mathrm{Hg}^{2+}$ pool following a simplified, first-order, rate equation (Delta Tributaries Mercury Council and the Sacramento River Watershed Program (DTMC/SRWP) 2002), which is affected by redox potential, tidal water movements, season, and light/dark conditions.

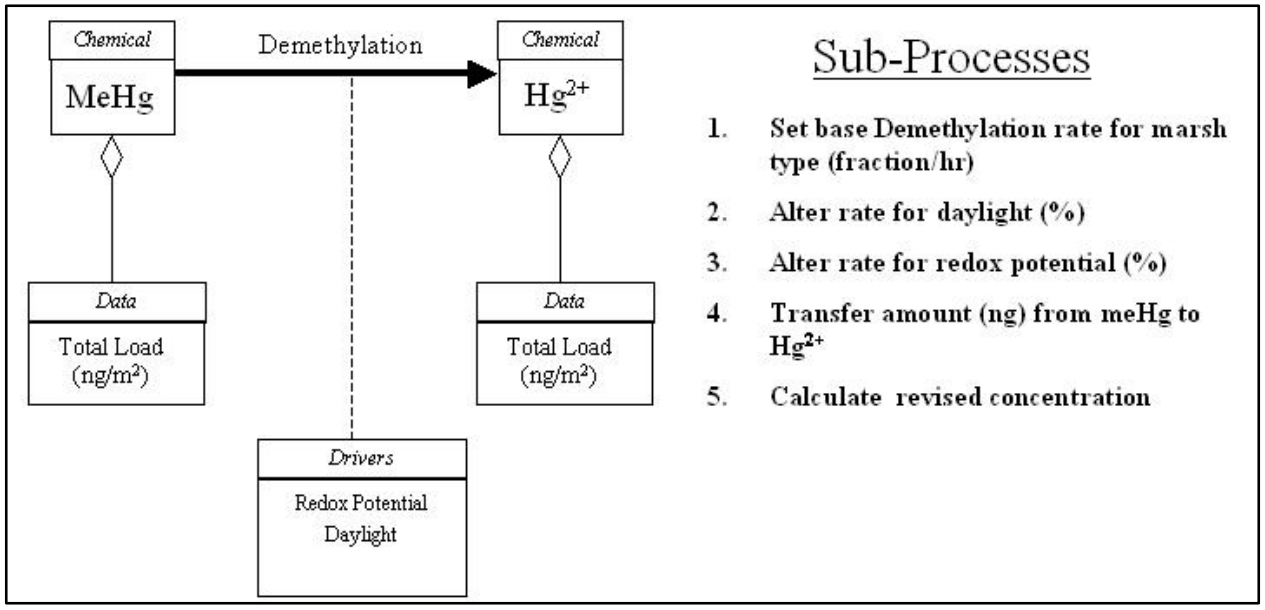

Figure 7-4. Overview of the QnD:HAAF Hg demethylation process

The base $\mathrm{MeHg}$ demethylation rates have been derived from the rates measured in the field in 2003, under dry season, daylight, and oxic conditions (Chapter 3 of this report). A description of the effects of season, daylight, and redox potential on methylation is given in Appendix B.

In the model, the amount of $\mathrm{MeHg}$ demethylated hourly in each spatial area is calculated as a percentage of the $\mathrm{MeHg}$ pool, as follows:

$$
\text { demethHg }_{t}=\text { BaseRate }_{\text {Demeth }} \times \operatorname{Re} \text { dox }_{d}(\text { hours }) \times \text { Light }_{d}(\text { daylight }) \times \mathrm{MeHg}_{t}
$$


where

$$
\begin{aligned}
\text { BaseRate }_{\text {demeth }}= & \text { MeHg demethylation rate (ng MeHg demethylated } \mathrm{ng}^{-1} \\
& \text { MeHg hr } r^{-1} \\
\text { Redox } \left._{\mathrm{d}} \text { (hours }\right)= & \text { redox potential effect on demethylation rate depending on } \\
& \text { the cumulative number of hours under water or extending } \\
& \text { above the water level }(-) \\
\text { Light }_{\mathrm{d}}(\text { daylight })= & \text { daylight effect on demethylation rate depending on time of } \\
& \text { day }(-) \\
\mathrm{MeHg}= & \text { size MeHg pool (ng DW) }
\end{aligned}
$$

Simple MeHg export from sediments. In QnD:HAAF, MeHg is exported from the sediments at a constant rate as described in Table 3-12. It is assumed that 0.8 percent of the resident $\mathrm{MeHg}$ load in the sediment is exported per day, i.e., 0.0333 percent per hour. This amount of $\mathrm{MeHg}$ enters into a general pool that quantifies the potential $\mathrm{MeHg}$ export to the bay.

\section{Biota}

Selected organisms are included in the QnD:HAAF model, i.e., plants, invertebrates, and one vertebrate animal (a bird). Two emergent macrophytic plant species and one microalgal group are represented in the current version of QnD:HAAF. Salicornia virginica (pickleweed) and Spartina foliosa (cord grass) are simulated at the simplest level as an established standing crop with constant biomass over the 2-week simulation. Plant $\mathrm{MeHg}$ load (ng) and potential contribution to export were assumed to be the primary data of interest in these simulations. The epipelon is also a potential contributor to the export of $\mathrm{MeHg}$. The values on plant biomass, $\mathrm{THg}$ and $\mathrm{MeHg}$ concentrations to calibrate the model are reported in Chapter 3 of this report. The following wetland invertebrates are modeled as potentially resident in all four spatial areas, but with population size and biomass being spatial area-specific: ribbed mussel (Geukensia Demissa), yellow shore crab (Hemigrapsus Oregonensis), and the eastern mud snail (Iyanassa obsoleta). These animals have been identified in HAAF field samples (Chapter 3 of this report). For exploring the trophic transfer and bioaugmentation of $\mathrm{MeHg}$ to higher levels in the food chain, the California clapper rail (Rallus longirostris obsoletus) is included as potentially resident in all four spatial areas. For the time being, it is assumed that biota do not migrate between spatial areas.

Biomass-related processes. In this QnD:HAAF version, the relationships between consumers and their food sources are formulated as a predator-prey relationship (Figure 7-5). According to this approach, when a mud snail grazes epipelon, the mud snail would be a predator and the epipelon would be a prey. The uptake of prey biomass by the predator is calculated as follows:

$$
\text { Intake }_{\text {pred }}=\text { Biom }_{\text {pred }} \times \text { DemandRate }_{\text {prey }}
$$

where 


$$
\begin{aligned}
\text { Intake }_{\text {pred }}= & \text { amount of prey biomass ingested by a specific predator } \\
& (\mathrm{g} \text { DW }) \\
\text { Biom }_{\text {pred }}= & \text { predator biomass }(\mathrm{g} \mathrm{DW}) \\
\text { DemandRate }_{\text {prey }}= & \text { amount of prey required per unit weight of the predator } \\
& (\mathrm{g} \text { DW prey per g DW predator) }
\end{aligned}
$$

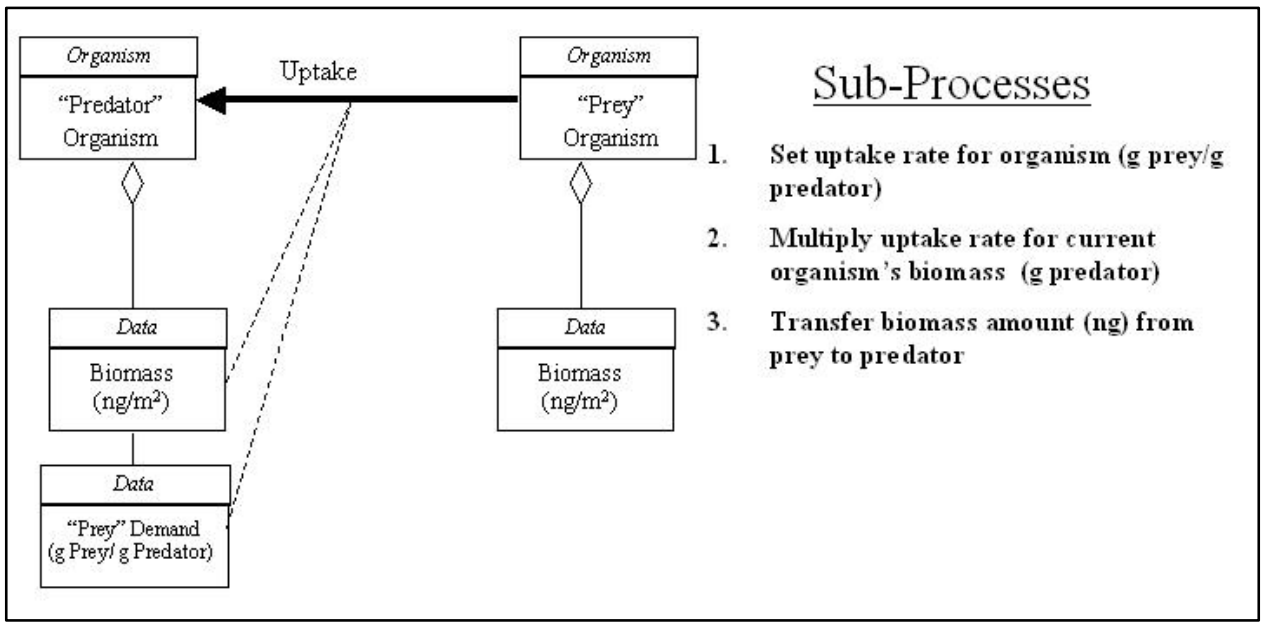

Figure 7-5. Overview of the QnD:HAAF organism biomass intake process

The biomass of the prey is transferred from the prey pool to the predator pool (Intake $\left.{ }_{\text {pred }}\right)$. If the prey pool is smaller than the demand of the predator, all available prey biomass is transferred to the predator. The predators and prey demand rates are listed in Appendix B.

Biomass loss. Long-term changes in biomass due to growth and respiration are not included. The biomass of plants (Salicornia, Spartina, and epipelon) and ribbed mussels is assumed to be constant within the 2-week simulation period. However, for animals that consume prey organisms (mud snails, shore crabs, and clapper rails) and, thus, would increase in biomass, a mass-loss rate is introduced that is set equal to the biomass uptake rate to enable the simulation of trophic transfer of MeHg. The mass loss rates are listed in Appendix B.

Uptake of MeHg directly from sediment. In QnD:HAAF, all biota have uptake and loss processes that allow them to potentially bioaccumulate and release MeHg. This methodology is in accordance with DTMC/SRWP (2002), recommending an initial simplified approach, followed by a detailed bioenergetic approach once $\mathrm{MeHg}$ data become available on higher trophic levels. Data on uptake and bioaccumulation of $\mathrm{MeHg}$ from soil, sediment, and pore water are still extremely scarce in the literature, and they are, therefore, largely estimated from most recent research reported in Chapters 3-6 of this report, and from Mason et al. (1996), Rogers (1995), and Barber (2001).

Uptake of $\mathrm{MeHg}$ from sediment is shown in Figure 7-6, and calculated as follows: 


$$
\text { MeHgIntake }_{\text {sed }}=\text { Biomass } \times \text { Transfer }_{\text {sed }} \times \operatorname{Sat}\left(\mathrm{MeHg}_{\text {conc }}\right)
$$

where

MeHgIntake $_{\text {sed }}=$ uptake of MeHg from sediment (ng)

Biomass $=$ biomass organism $(\mathrm{g} \mathrm{DW})$

Transfer $_{\text {sed }}=$ potential MeHg transfer rate from sediment into organism (ng g ${ }^{-1}$ organism-DW)

$\operatorname{Sat}\left(\mathrm{MeHg}_{\text {conc }}\right)=$ relative function that reduces $\mathrm{MeHg}$ uptake to 0.0 when the species-characteristic initial (equilibrium) $\mathrm{MeHg}$ concentrations are reached

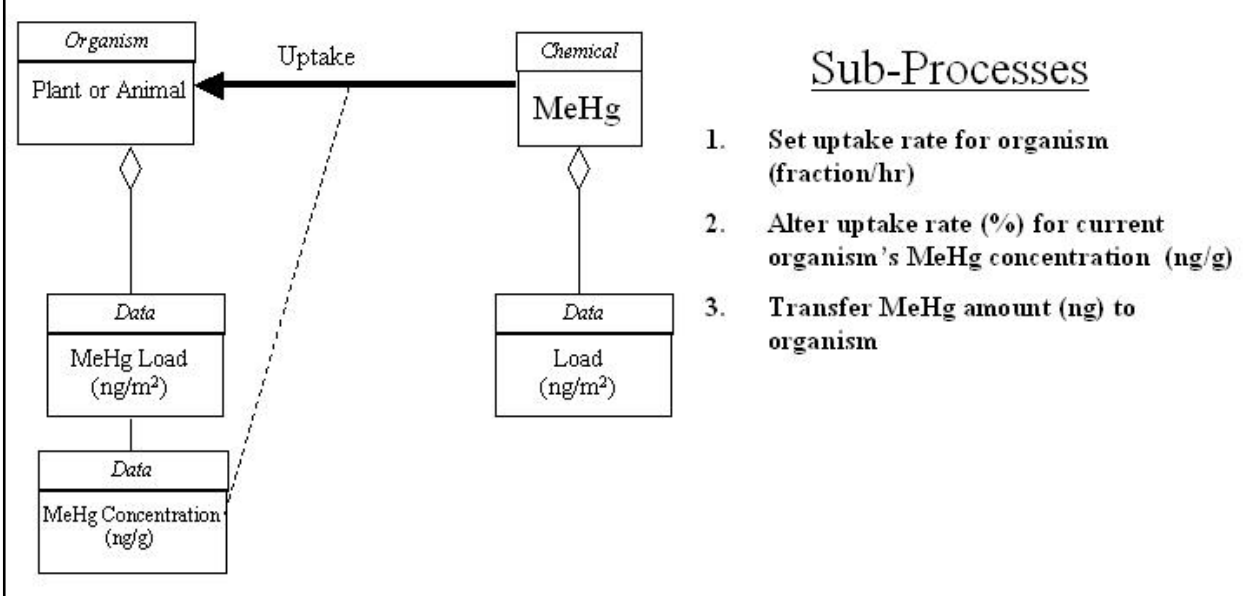

Figure 7-6. Overview of the QnD:HAAF organism MeHg intake from sediment

$\mathrm{MeHg}$ will only be taken up from the sediment when the $\mathrm{MeHg}$ concentration in the organism is below the concentration measured in the field, since the latter is assumed to be in equilibrium with the environment. One potential $\mathrm{MeHg}$ transfer rate from sediment into organism is used for all organisms. This Transfer $r_{\text {sed }}$ value $\left(0.14042 \mathrm{ng} \mathrm{MeHg} \mathrm{g}{ }^{-1} \mathrm{DW} \mathrm{hr}^{-1}\right)$ was measured in preliminary uptake experiments with $\mathrm{Hg}^{2+}$ on a Macoma species that filters sediment (Chapter 6 of this report). More species-characteristic uptake/transfer rates will be included when these become available.

Uptake of MeHg from grazing or predation by predator. Uptake of $\mathrm{MeHg}$ by ingestion of biotic food sources is shown in Figure 7-7, and is calculated as follows (this equation has been formulated after Rogers (1994)):

$$
\text { MeHgIntake }_{\text {prey }}=\text { Biomass }_{\text {pred }} \times \text { PreyConsumed } \times \mathrm{MeHg}_{\text {prey }}
$$

where

MeHgIntake $_{\text {prey }}=$ uptake of MeHg from ingesting a prey (ng)

$$
\text { Biomass }_{\text {pred }}=\text { biomass predator }(\mathrm{g} \mathrm{DW})
$$


Prey Consumed $=$ biomass prey consumed $(\mathrm{g}$ prey-DW)

$\mathrm{MeHg}_{\text {prey }}=\mathrm{MeHg}$ concentration prey (ng g $\mathrm{g}^{-1}$ prey-DW)

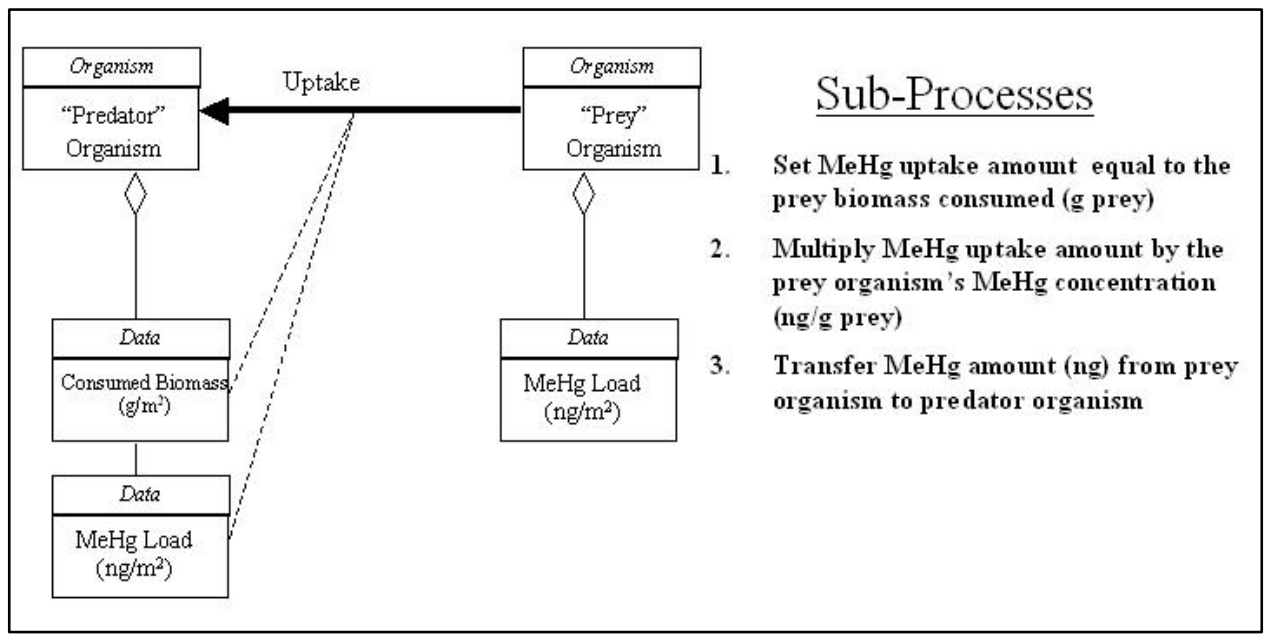

Figure 7-7. Overview of the QnD:HAAF organism MeHg intake from biomass

MeHg loss from biota. All macrophytes lose about 50 percent of their biomass per year (estimate Chapter 3 of this report), and, based on this estimate they would also lose that percentage of the $\mathrm{MeHg}$ contained in the plant biomass. In QnD:HAAF all plants, i.e. macrophytes and epipelon, are modeled as losing 50 percent of the $\mathrm{MeHg}$ contained in their maximum standing crop per year, i.e., $5.7078 \times 10^{-3}$ percent $\mathrm{hr}^{-1}$. All animals, including the ribbed mussels with constant biomass, are assumed to release 10 percent of their resident $\mathrm{MeHg}$ load per day, i.e., 0.4167 percent $\mathrm{hr}^{-1}$. The latter value is based on a study on elimination of $\mathrm{THg}$ and $\mathrm{MeHg}$ by the zooplankter Daphnia magna feeding on phytoplankton (Tsui and Wang 2004). This MeHg released enters into a general pool that quantifies the potential $\mathrm{MeHg}$ export to the bay.

\section{QnD:HAAF V1.0 Model Results}

Two 14-day scenarios were simulated using QnD, i.e., one scenario representing the wet season (1-14 February 2004) and one scenario representing the dry season (1-14 June 2003). The results for all spatial areas, i.e., Salicornia Marsh, Spartina Marsh, Mud Flat, and SubTidal, are presented separately, and expressed per square meter to facilitate comparison between areas. In situ, however, the spatial areas differ in size.

The relative size of all successive pools has a large impact on the amount of $\mathrm{MeHg}$ transported throughout the system. Each pool size is at least two or three orders of magnitude larger than those of the subsequent pools. For example, within the Salicornia Marsh the THg pool of the sediment $\left(\approx 8.9 \times 10^{6} \mathrm{ng} \mathrm{m}^{-2}\right)$ is far larger than the MeHg pool of the sediment $\left(\approx 38,000 \mathrm{ng} \mathrm{m}^{-2}\right)$, which, in turn, is larger than the MeHg pools in plants $\left(\approx 5,000 \mathrm{ng} \mathrm{m}^{-2}\right.$ to $\left.430 \mathrm{ng} \mathrm{m}^{-2}\right)$, which are larger than most $\mathrm{MeHg}$ pools in other biota $\left(\approx 58 \mathrm{ng} \mathrm{m}^{-2}\right.$ to $\left.0.8 \mathrm{ng} \mathrm{m}^{-2}\right)$. The effect of these unequal pool sizes is that rates are usually unlimited, except in 
cases where the prey demand of the predator is not met. Given the 2-week simulations, prey levels were always large enough to meet predator demands. The $\mathrm{THg}$ pool is assumed to be large enough to make it a non-limiting source for methylation and the $\mathrm{MeHg}$ pool large enough to be non-limiting for uptake into organisms. However, seasonal and environmental drivers control and alter the methylation and demethylation rates, whereas trophic transfer of $\mathrm{MeHg}$ occurs at constant rates, depending on organism.

\section{Hg dynamics in spatial areas}

Comparison of simulated and measured methylation rates. An important means to build confidence in the capabilities of QnD:HAAF to generate results that reflect what is happening in the ecosystems of interest is to compare simulated results with measured values. Several cases are illustrated below.

The QnD model was used to simulate methylation and demethylation rates in the Salicornia-vegetated High Marsh spatial area over a 2-week period. The simulated values were compared with values measured in a Salicornia-vegetated High marsh along San Francisco Bay by Marvin-DiPasquale et al. (2003). The simulated methylation and demethylation rates of 8.45 and $7.47 \mathrm{ng} \mathrm{g}^{-1} \mathrm{DW} \mathrm{day}{ }^{-1}$, respectively, were similar to the rates described by Marvin-DiPasquale et al. (2003). A more detailed analysis and comparison of methylation and demethylation rates described in this report and those measured by Marvin-DiPasquale et al. (2003) are given in Chapter 3 of this report.

As with any modeling effort, more comparisons of simulated values with measured ones will increase the confidence of a model's performance.

Comparison of simulated MeHg concentrations and transfer rates under wet and dry season conditions. The $\mathrm{MeHg}$ concentrations simulated over a 2-week period in the four spatial areas under wet and dry season conditions are presented in Figure 7-8. The MeHg concentrations in the sediment increased far more during the wet season than during the dry season. Increases were several orders of magnitude larger in vegetated sediments than in nonvegetated sediments (note the differences in scale of the vertical axes in Figure 7-8), and dynamic patterns of $\mathrm{MeHg}$ concentrations differed greatly between spatial areas. The increase in $\mathrm{MeHg}$ concentration in the wet season is due to the increasing seasonal effect on methylation rate (described in Table B3). The simulated $\mathrm{MeHg}$ concentrations in the Salicornia marsh were $14 \mathrm{ng} \mathrm{g}^{-1} \mathrm{DW}$ in the wet season and $1.6 \mathrm{ng} \mathrm{g}^{-1}$ in the dry season. The concentrations in the Spartina marsh and Mud Flat varied more dynamically under the influence of tidal activity and the inherent changes in redox potential. The concentrations in the Spartina marsh ranged from 5 to $20 \mathrm{ng} \mathrm{g}^{-1}$ in the wet season, and from 0.5 to $2 \mathrm{ng} \mathrm{g}^{-1}$ in the dry season. The concentrations in the Mud Flat ranged from $10 \mathrm{ng} \mathrm{g}^{-1}$ in the wet season to $4 \mathrm{ng} \mathrm{g}^{-1}$ in the dry season. $\mathrm{MeHg}$ in the SubTidal area increased slowly in the wet season (up to $2.5 \mathrm{ng} \mathrm{g}^{-1} \mathrm{DW}$ ) and remained almost constant in the dry season (1.8 $\left.\mathrm{ng} \mathrm{g}^{-1} \mathrm{DW}\right)$. Explanations for the differences in levels and dynamic patterns of $\mathrm{MeHg}$ concentrations can easily be explored using QnD:HAAF, since the model enables rapid data capture and visualization of temporal behavior of 
the processes and factors believed to drive $\mathrm{MeHg}$ concentrations, i.e. methylation, demethylation processes and onsite hourly water depth and redox potential.

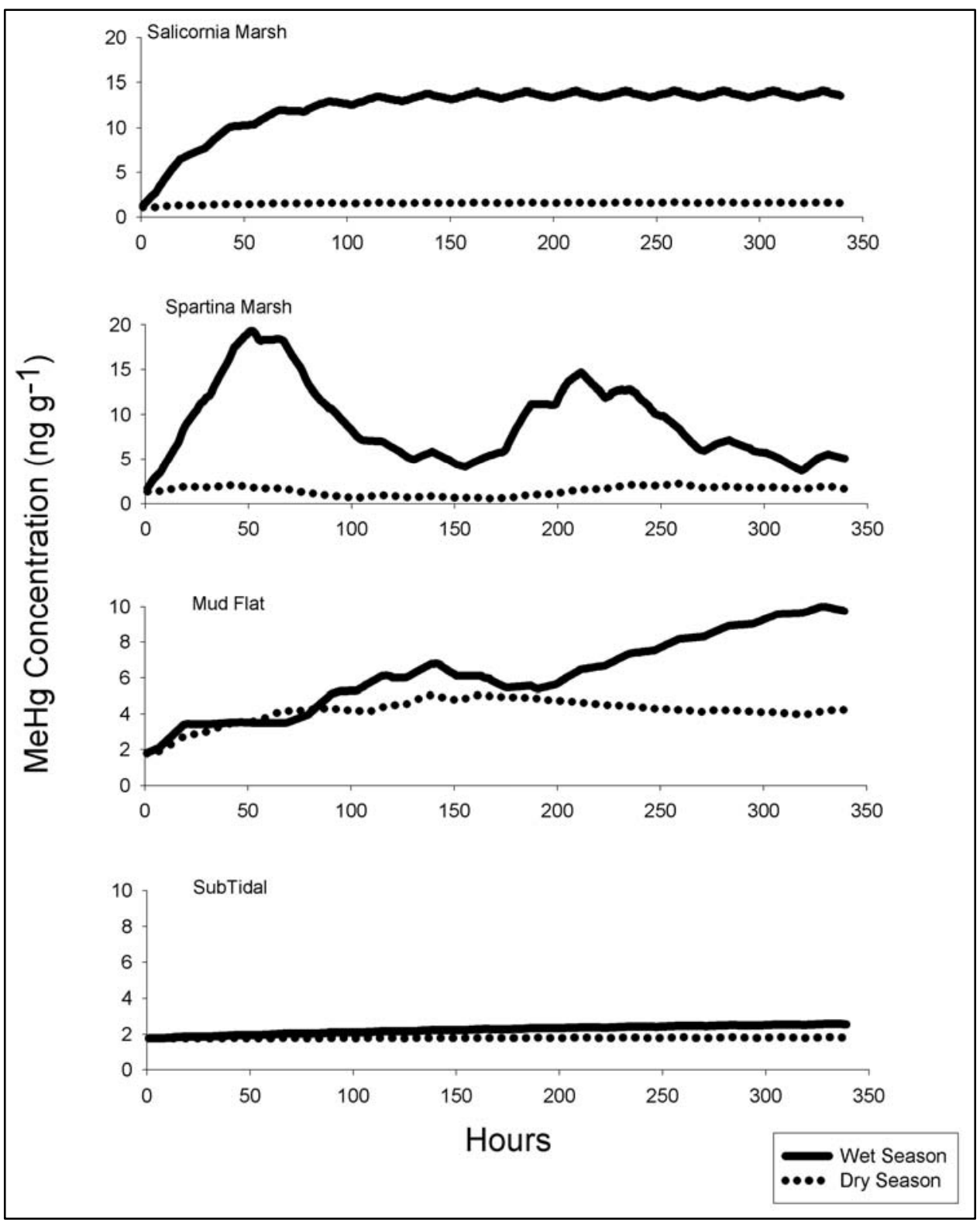

Figure 7-8. Simulated MeHg concentrations in surface sediments of four spatial areas

Figure 7-9 presents the simulated methylation and demethylation rates that lead to the $\mathrm{MeHg}$ concentrations in the spatial areas shown in Figure 7-8. Also in this case, the increasing effect of the wet season is apparent (Table B3). The regular, short-term (12-hr) cyclical fluctuations in methylation and demethylation rates are caused by daylight effects (Tables B4 and B6). The methylation and demethylation rates in the Salicornia marsh and SubTidal spatial areas show regularly cycling, consistent equilibrium rates. The methylation and demethylation rates in the Spartina marsh and Mud Flat spatial areas show irregular fluctuations in activity, caused by effects of tidal inundation and redox 
(Figures B6 and B8). The two humps in MeHg transfer in the Spartina marsh, i.e. after 0-80 and 180-250 $\mathrm{hr}$ (Figure 7-9), are reflected clearly in the $\mathrm{MeHg}$ concentrations (Figure 7-8), since the methylation rates are higher than the demethylation rates on a sediment-dry weight basis (sediments contain 100 times more $\mathrm{THg}$ than $\mathrm{MeHg}$ ). The hump in $\mathrm{MeHg}$ transfer in the Mud Flat, i.e. after 80-200 hr (Figure 7-9), is barely visible by affecting the MeHg concentrations (Figure 7-8), since the methylation and demethylation rates are in the same order of magnitude during this period in this spatial area. The methylation and demethylation rates do not reach equilibria during the 2-week simulated period in the Spartina marsh and Mud Flat spatial areas.

\section{Mercury dynamics in biota}

QnD:HAAF simulation results indicated a significant bioaccumulation potential of $\mathrm{MeHg}$ from lower to higher trophic levels, regardless of season. The dynamics in bioaccumulation potential depend on the size of the available $\mathrm{MeHg}$ pools in the sediment and are greatly affected by the MeHg body burdens of the biota in each of the four spatial areas.

Hg dynamics in plants. At this stage of QnD:HAAF development, the biomass and initial MeHg levels in all plants (Salicornia, Spartina, and epipelon) were kept at measured levels and did not change, because they were only measured at one point in time. This was done to keep initial model development simple. However, macrophytes and algae play important roles in the food webs in Californian coastal wetlands, as pointed out in Chapter 3 - tidal marsh vegetation zones, and these relationships have to be investigated further. Thus, based on this simplified assumption, Salicornia and Spartina had little influence on the overall $\mathrm{MeHg}$ dynamics within the sediment and in animals. Simulated uptake of $\mathrm{MeHg}$ by the plants was only to replace what was lost via simple export.

Hg dynamics in animals. At this stage of QnD:HAAF development, the simulations were started from biomass and initial MeHg levels in all animals (mussels, snails, shore crabs, and clapper rails) measured at one point in time (Chapter 3 of this report; Table B8). Simulation results conducted for the dry and wet seasons showed that the $\mathrm{MeHg}$ pools in the various spatial areas were large enough to allow unlimited uptake and bioaccumulation of $\mathrm{MeHg}$ in animals.

Simulation results on sediment-dwelling animals with a high biomass, such as the ribbed mussel in the Mud Flat and Sub Tidal spatial areas, indicated that these animals exhibit stable uptake and retention of $\mathrm{MeHg}$ because their biomass is high and losses from predation by clapper rails and crabs are small. This can be explained by the fact that most potential losses of $\mathrm{MeHg}$ from these animals, ranging from 0.43 in the High Marsh spatial area to $14.9 \mathrm{ng} \mathrm{m}^{-2}$ day $^{-1}$ in the Sub Tidal spatial area, were regained through uptake of $\mathrm{MeHg}$ through the ingestion of sediment. Given the current assumptions of QnD:HAAF, ribbed mussels and epipelon may play similar roles as mid-level organisms in the food chain transfer of MeHg. These preliminary judgments are based on the assumptions of large, initial biomass levels with no short-term changes in biomass. Once biomass growth and mortality are simulated, these dynamics may result in different conclusions. 


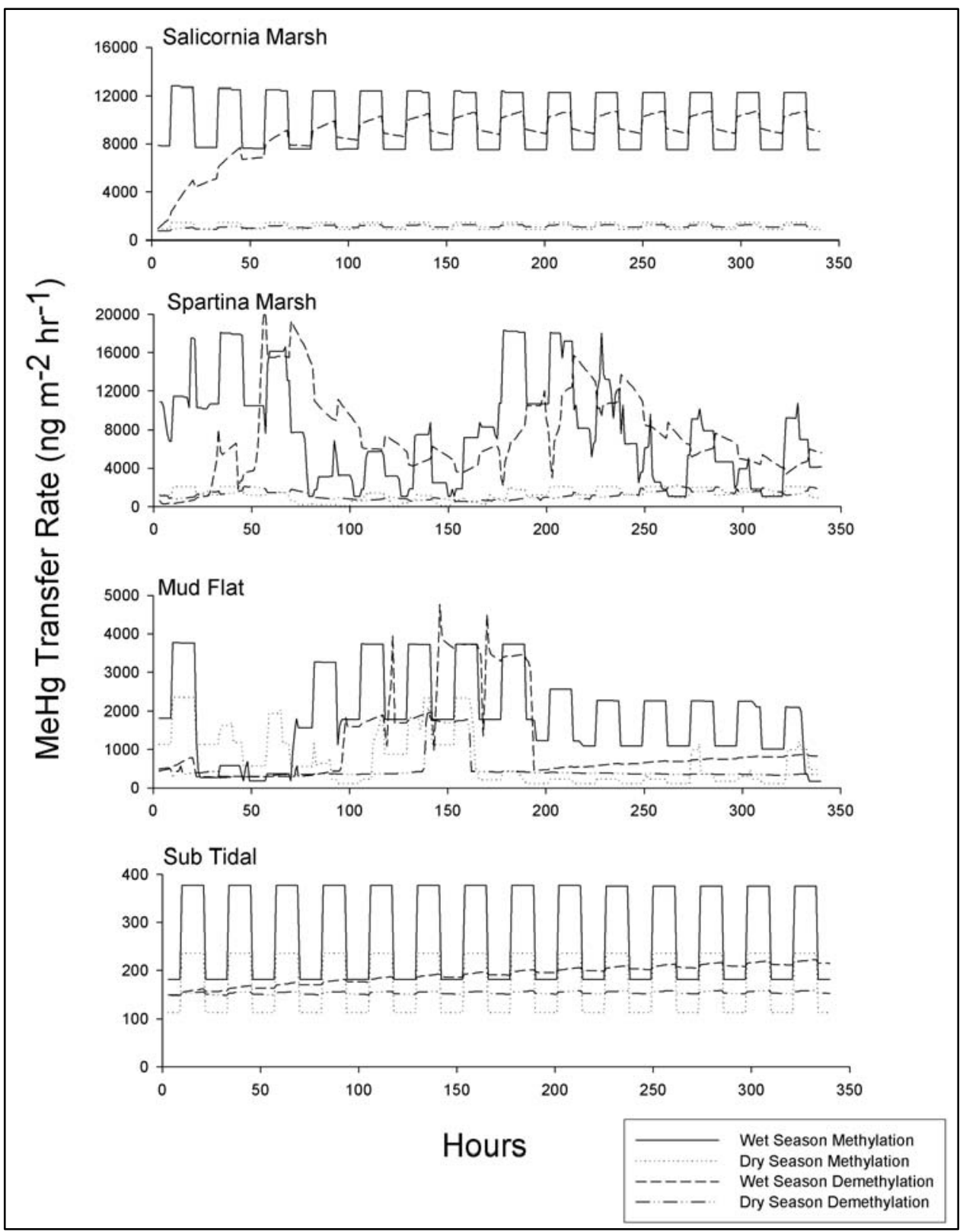

Figure 7-9. Simulated methylation and demethylation rates in surface sediments of four spatial areas

Simulation results on sediment-dwelling animals with a lower biomass than mussels, such as eastern mud snails $\left(0.1\right.$ to $\left.1.0 \mathrm{~g} \mathrm{DW} \mathrm{m}^{-2}\right)$, showed that these animals are more sensitive to predation by crabs and clapper rails, since their biomass decreased in both seasons over the 2 -week period. The snails are different from mussels in that they bioaccumulate $\mathrm{MeHg}$ directly from sediment and by consuming epipelon. Because sediment and epipelon pools are large, the uptake of $\mathrm{MeHg}$ by snails was unlimited. The $\mathrm{MeHg}$ concentration in snails remained, therefore, close to the initial level of $7.9 \mathrm{ng} \mathrm{MeHg} \mathrm{g}^{-1}$. In addition, because of the low biomass and $\mathrm{MeHg}$ body burdens, the potential loss of $\mathrm{MeHg}$ from these animals ( 0.036 to $0.36 \mathrm{ng} \mathrm{m}^{-2}$ day $^{-1}$ ) was also small compared to exports from other MeHg sources. 
Yellow shore crabs have a biomass on the same order of magnitude as eastern mud snails and a relatively lower $\mathrm{MeHg}$ body burden at equilibrium, but provide a significant resource for predators higher in the food chain. Simulation results indicated that the biomass of the crabs decreased substantially and in all spatial areas in both seasons over the 2-week period due to the assumed biomass loss and predation by clapper rails. The $\mathrm{MeHg}$ concentration in crabs decreased slightly, i.e. 1.72 to $1.68 \mathrm{ng} \mathrm{g}^{-1}$, over the simulation period since the $\mathrm{MeHg}$ loss rate decreased the $\mathrm{MeHg}$ loads of the crabs. In exploratory sensitivity analysis simulations, biomass and $\mathrm{MeHg}$ concentrations of the crabs were more sensitive to assumed biomass loss than to direct $\mathrm{MeHg}$ loss from biomass - probably because the $\mathrm{MeHg}$ concentration at equilibrium was extremely low.

The clapper rail is considered a "capstone" species. It has the lowest biomass of all animals considered in HAAF-QnD, and the initial MeHg concentration was set purposely low to explore the bioaccumulation of $\mathrm{MeHg}$. Simulated results indicated that under the initial diet and $\mathrm{MeHg}$ assumptions, clapper rails may bioaccumulate $\mathrm{MeHg}$ to substantial levels within an ecosystem such as HAAF. All clapper rail $\mathrm{MeHg}$ concentrations increased from 0.3 to $12 \mathrm{ng} \mathrm{g}^{-1}$ almost entirely through their diet of snails, crabs, and mussels. As stated earlier, the rate of bioaccumulation for individuals depends on diet, biomass loss, and $\mathrm{MeHg}$ loss, as well as habitat utilization.

Export. Potential export of $\mathrm{MeHg}$ is considerable in all spatial areas. In QnD:HAAF, "potential export" encompasses all potential MeHg export pathways, i.e. export with tidal movements and by volatilization. Simulated results show a large difference in export spatial areas and seasons (Figure 7-10). In the wet season, the Spartina Marsh had the highest potential for export (ranging from 180 to $50 \mathrm{ng} \mathrm{m}^{-2} \mathrm{hr}^{-1}$ ). Potential export from Salicornia Marsh was more constant (120 ng m $\mathrm{m} \mathrm{hr}^{-1}$ ). In the dry season the same Salicornia Marsh had a far lower export potential $\left(15 \mathrm{ng} \mathrm{m}^{-2} \mathrm{hr}^{-1}\right)$. The highest dry season export potential was realized by the MudFlat at 40 to $45 \mathrm{ng} \mathrm{m}^{-2} \mathrm{hr}^{-1}$.

By scaling the sizes of the spatial areas up to an area with the size of the future HAAF tidal wetland, i.e. 203 ha, insights were gained into the consequences of wetlands such as the HAAF-wetland for the MeHg TMDLs in San Pablo Bay. The calculation of the conversion factor used for scaling up is presented below:

$1 \mathrm{ng} \mathrm{MeHg} \mathrm{m} \mathrm{hr}^{-1}=1 \times 10^{-12} \times 10^{4} \times 24 \times 365 \mathrm{~kg} \mathrm{MeHg} \mathrm{ha}^{-1} \mathrm{yr}^{-1}$ or $8.76 \times 10^{-5} \mathrm{~kg} \mathrm{MeHg} \mathrm{yr}^{-1}$ 


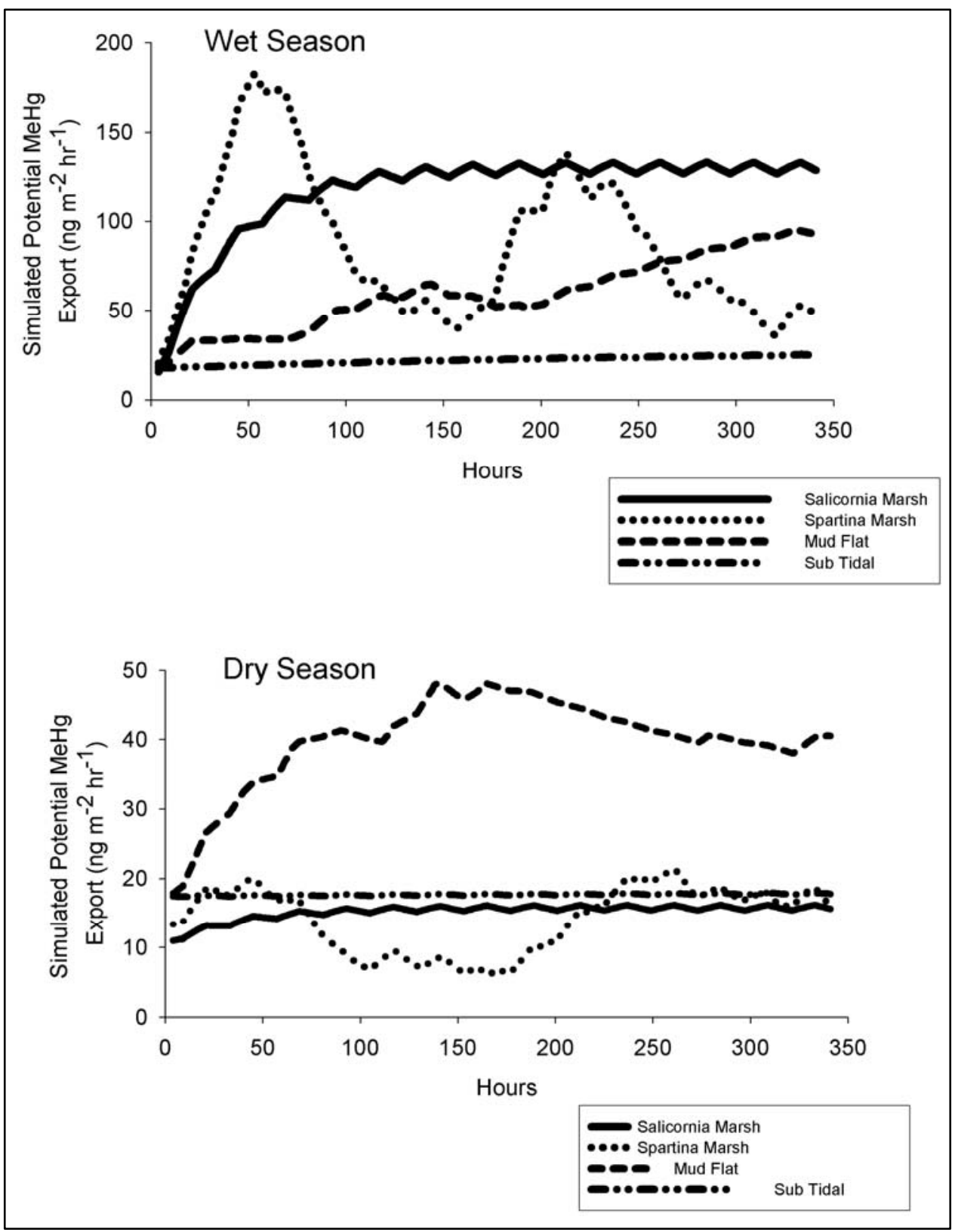

Figure 7-10. Simulated MeHg export rates from surface areas of four HAAF spatial areas

Net export potential would be expected to range from 2.3 to

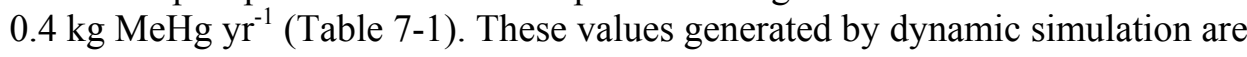
3 to 10 times higher than those derived from relatively simple calculations using static measured values, as presented in Table 3-12. Dynamic simulations generally yield higher production and export values for ecosystems than calculations based on values collected at only one point in time or on values collected with a very low frequency. However, for the current HAAF case and for other wetland restoration and creation plans it would be prudent to narrow the range of potential $\mathrm{MeHg}$ export and fate, effects, and consequences for the $\mathrm{MeHg}$ food chain. 


\begin{tabular}{|c|c|c|c|c|}
\hline \multicolumn{5}{|c|}{$\begin{array}{l}\text { Table 7-1 } \\
\text { Simulated Potential Export and Contribution to the MeHg TMDL }\end{array}$} \\
\hline \multirow[b]{2}{*}{ Spatial Area } & \multicolumn{2}{|c|}{\begin{tabular}{|c|} 
Potential Export Simulated by \\
QnD:HAAF
\end{tabular}} & \multicolumn{2}{|c|}{$\begin{array}{c}\begin{array}{c}\text { Potential Contribution HAAF To } \\
\text { MeHg TMDL }^{1}\end{array} \\
\end{array}$} \\
\hline & $\begin{array}{l}\text { Wet Season } \\
\left(\mathrm{ng} \mathrm{m}^{-2} \mathrm{hr}^{-1}\right) \\
\end{array}$ & \begin{tabular}{|l|} 
Dry Season \\
$\left(\mathrm{ng} \mathrm{m}^{-2} \mathrm{hr}^{-1}\right)$ \\
\end{tabular} & \begin{tabular}{|l}
$\begin{array}{l}\text { Wet season } \\
\left(\mathrm{kg} \mathrm{MeHg} \mathrm{yr}^{-1}\right)\end{array}$ \\
\end{tabular} & \begin{tabular}{|l|l|}
$\begin{array}{l}\text { Dry season } \\
\left(\mathrm{kg} \mathrm{MeHg} \mathrm{yr}^{-1}\right)\end{array}$ \\
\end{tabular} \\
\hline Salicornia Marsh & 120 & 15 & 2.13 & 0.27 \\
\hline Spartina Marsh & $38-180$ & $5-20$ & $0.68-3.2$ & $0.09-0.36$ \\
\hline Mud Flat & $50-90$ & $40-50$ & $0.89-1.6$ & $0.71-0.89$ \\
\hline Sub Tidal & $16-24$ & 17 & $0.28-0.43$ & 0.30 \\
\hline
\end{tabular}

\section{Initial answers to questions raised at the CALFED Stakeholders Workshop, 8-9 October 2002, Moss Landing Marine Laboratories}

What are the present levels of MeHg in SF Bay wetlands with respect to biota and sub-habitats within the Bay? $\mathrm{MeHg}$ levels in biota were simulated in such a way that they could not exceed the equilibrium concentrations measured in the field samples. The QnD:HAAF simulation results indicated a significant bioaccumulation potential of $\mathrm{MeHg}$ from lower to higher trophic levels, regardless of season. Simulations were greatly inhibited by the lack of available data on food chain structure, components, and $\mathrm{MeHg}$ accumulated in the biota.

The initial, measured (Chapter 3 of this report), $\mathrm{MeHg}$ concentrations in the sediments ranged from 1.1 to $1.8 \mathrm{ng} \mathrm{MeHg} \mathrm{g}^{-1} \mathrm{DW}$. The simulated $\mathrm{MeHg}$ levels in the four sub-habitats, represented by spatial zones in QnD:HAAF, showed dynamics that depended on season and redox levels. MeHg concentrations increased over the 2-week simulation period in all areas and both seasons to levels vastly exceeding the measured levels.

What are the rates of $\mathrm{MeHg}$ production? The simulated methylation and demethylation rates ranged from 100 to $20,000 \mathrm{ng} \mathrm{m}^{-2} \mathrm{hr}^{-1}$, depending on environmental conditions. Measured field data and estimated effects of daylight, redox potential via tidal movements, and season were used as a basis for these simulations. The fluctuations in methylation and demethylation due to the effect of time of day were regular, and the effect was similar in all spatial areas. Within areas that were frequently flooded and exposed to air, the redox potential became an important driver. The four spatial zones exhibited methylation rates that varied considerably with the tidal movements, because of the assumed 90-percent decreased methylation under air-exposed conditions. Methylation was assumed to be increased by a factor of 9 during the wet season compared to methylation in the dry season and, therefore, directly affected net $\mathrm{MeHg}$ production and pool size. The first simulation results compare favorably with the scarce values published for similar marsh areas. However, more monitoring data are required on the variation in net $\mathrm{MeHg}$ production in spatial zones and locations within the bay, for higher confidence in the potential of the QnD:HAAF model. 
What factors control MeHg production? Can these be managed? Based on current understanding and modeling, most factors that are believed to control $\mathrm{MeHg}$ production and bioaccumulation are not easily managed. The primary management option with known influence is elevation. The importance of elevation is illustrated by the large differences in simulated methylation and demethylation rates in the Spartina Marsh and the Mud Flat areas that only differ $0.5 \mathrm{ft}$ in elevation. Since net $\mathrm{MeHg}$ production is a microbial process, factors influencing this process deserve to be explored further.

Are some wetlands larger Hg exporters than others? The current version of QnD:HAAF does not offer a detailed description of export in terms of $\mathrm{THg}$ and $\mathrm{MeHg}$ movement with tides or volatilization. All exported $\mathrm{MeHg}$ is deposited into one "potential export" pool. However, simulated export from the four spatial zones proved to be vastly different. Consequently, based on these simulations it is to be expected that wetlands predominated by a relatively large share of Salicornia Marsh and Spartina Marsh may produce a relatively high contribution to the MeHg TMDL in the bay. Moreover, wetlands in which the spatial zones are changing because of recent restoration may have export regimes that differ from those in established wetlands.

Simulated export greatly exceeds the export estimated from simple calculations using static values measured in the dry season, as presented in Table 3-12. Dynamic simulations generally yield higher production and export values for ecosystems than calculations based on values collected at only one point in time or on values collected with a very low frequency. However, for the current HAAF case and for other wetland restoration and creation plans, it would be prudent to further narrow the discrepancy between simulated and measured export.

Can we model/predict the effects of wetland restoration on MeHg production and export? Models exist as testing platforms of concepts and measured data. The predictive power of models usually grows with the confidence of the users in the concepts and data on which the models are based, and in the model results that reflect phenomena users can observe. QnD:HAAF v1.0 development is based 10 percent on concepts and literature data and 90 percent on data measured in 2003. Even with this very limited first year data set, the model results have generated several interesting points for discussion and further exploration.

\section{The Way Forward: Recommendations for Research}

From comparisons of simulated and measured data, it is concluded that:

a. Large discrepancies exist between the simulated $\mathrm{MeHg}$ concentrations in the sediments of the spatial areas distinguished and the measured $\mathrm{MeHg}$ concentrations. 
$b$. Large discrepancies exist between the simulated export of $\mathrm{MeHg}$ from wetlands and the $\mathrm{MeHg}$ export calculated from measured values, causing uncertainties in the contribution of wetlands to the MeHg TMDL of the bay.

c. Large uncertainty exists on how the most important factors controlling net $\mathrm{MeHg}$ production influence this microbially mediated process.

d. A large data gap exists on the $\mathrm{MeHg}$ concentrations in sediments of various locations within the bay.

e. A large data gap exists on food chain structure, components, and $\mathrm{MeHg}$ accumulated in the biota of San Francisco Bay wetlands.

The authors recommend that future research and modeling efforts be directed into collecting data through monitoring and experimental studies to fill the data gaps, and increase understanding of ecosystem functioning and the reasons for discrepancies between simulated and measured data. 


\section{References}

Allen, J. R. L. (1990). "Salt-marsh growth and stratification: A numerical model with special reference to the Severn Estuary, southwest Britain," Marine Geology 95, 77-96.

Allen, J. R. L. (1994). "A continuity-based sedimentological model for temperate-zone tidal salt marshes," Journal of the Geological Society, London 151, 41-49.

Alpers, C. N., and Hunerlach, M. P. (2000). "Mercury contamination from historic mining in California," Fact Sheet FS-061-00, U.S. Geological Survey, Sacramento, CA.

Barber, M. C. (2001). "Bioaccumulation and aquatic system simulator (BASS) user's manual beta test version 2.1." USEPA Report No. 600/R-01/035, http://www.epa.gov/AthensR/staff/members/barbermahlonc/bass21_manual. pdf. October 2004.

Bartlett, P. D., and Craig, P. J. (1981). "Total mercury levels in British estuarine sediments-II," Water Research 15, 37-47.

Batten, K. M., and Scow, K. M. (2003). "Sediment microbial community composition and methylmercury pollution at four mercury mine-impacted sites," Microbial Ecology 46, 429-441.

Benoit, J. M, Gilmore, C. C., Heyes, A., Mason, R. P., and Miller, C. L. (2003). "Geochemical and biological controls over methylmercury production and degradation in aquatic ecosystems," Biogeochemistry of environmentally important trace elements, ACS Symposium Series 835, Y. Cai and O.C. Braids, ed., American Chemical Society, Washington, DC.

Bloom, N. S. (1989). "Determination of picogram levels of methylmercury by aqueous phase ethylation, followed by cryogenic gas chromatography with cold vapor atomic fluorescence detection," Canadian Journal of Fisheries and Aquatic Sciences 46, 1131-1140.

Boehn, H. L. (1971). “Redox potentials,” Soil Science 112, 39-45. 
Brannon, J., Plumb, R. H., and Smith, I. (1980). "Long term release of heavy metals from sediments." Contaminants and sediments. R. A. Baker, ed., Vol. 2, Chapter 13, Ann Arbor Science Publ., 221-266.

Callaway, J. C. (2001). "Hydrology and substrate." Handbook for restoring tidal wetlands, J. B. Zedler, ed., Chapter 3, CRC Press, Boca Raton, FL, 89-111.

Callaway, J. C., Sullivan, G., and Zedler, J. B. (2003). "Species-rich plantings increase biomass and nitrogen accumulation in a wetland restoration experiment," Ecological Applications 13, 1626-1639.

Chan, H. M., Scheuhammer, A. M., Ferran, A., Loupelle, C., Holloway, J., and Weech, S. (2003). "Impacts of mercury on freshwater fish-eating wildlife and humans," Human and Ecological Risk Assessment 9, 867-883.

Choe, K-Y., Gill, G. A., Lehman, R. D., and Han, S. (2004). "Sediment-water exchange of total mercury and monomethyl mercury in the San Francisco Bay-Delta," Limnology and Oceanography 49, 1512-1527.

Day, P. R. (1956). "Report of the committee on physical analyses (1954-1955)," Soil Science Society of America Proceedings 20, 167-169.

Delta Tributaries Mercury Council and the Sacramento River Watershed Program. (2002). "Final strategic plan for the reduction of mercury-related risk in the Sacramento River watershed," Appendices 1 and 4, http://www.sacriver.org/subcommittees/dtmc/documents.html. October 2004.

Demuth, N., and Heumann, K. G. (2001). "Validation of methylmercury determinations in aquatic systems by alkyl derivatization methods for GC analysis using ICP-IDMS," Analytical Chemistry 73, 4020.

Dong, W., Lindberg, S. E., Meyers, T., Chatton, J. (2002). "A proposed mechanism of gaseous mercury emission mediated via aquatic plants in the Florida Everglades."

Faulkner, S. P., Patrick, W. H., Jr., and Gambrell, R. P. (1989). "Field techniques for measuring soil parameters," Soil Science Society of America Journal 53, 883-890.

Fredrickson, H. L., Cappenberg, T., and de Leeuw, J. (1986). "Polar lipid esterlinked fatty acid composition of Lake Vechten seston: An ecological application of lipid analysis," FEMS Microbial Ecology 38, 381-396.

Gardner, W. S., Kendall, D. R., Odom, R. R., Windom, H. L., and Stephens, J. A. (1978). "The distribution of methyl mercury in a contaminated salt marsh ecosystem," Environmental Pollution 15, 243-251.

Gill, R. G. (1979). "Status and distribution of the California clapper rail (Rallus longirostris obsoletus)," California Fish Game 65, 36-49. 
Gilmour, C. C., and Henry, E. A. (1991). "Mercury methylation in aquatic systems affected by acid decomposition," Environmental Pollution 71, 131-169.

Grossinger, R. (1995). "Historical evidence of freshwater effects on the plan form of tidal marshlands in the Golden Gate Estuary," Masters thesis, Department of Marine Sciences, University of California at Santa Cruz.

Hammerschmidt, C. R., and Fitzgerald, W. F. (2001). "Formation of artifact methylmercury during extraction from a sediment reference material," Analytical Chemistry 73, 5930-5936.

Heller, A. A., and Weber, J. H. (1998). "Seasonal study of speciation of mercury II and monomethylmercury in Spartina alterniflora from the Great Bay Estuary, NH," The Science of Total Environment 221, 181-188.

Heyes, A. (1996). "Methylmercury in natural and disturbed wetlands," Ph.D. diss., McGill University, Montreal, Canada.

Heyes, A., Moore, T. R., and Rudd, J. W. M. (1998). "Mercury and methylmercury in decomposing vegetation of a pristine and impounded wetland," Journal of Environmental Quality 27, 591-599.

Hintelmann, H., and Evans, R. D. (1997). "Application of stable isotopes in environmental tracer studies - Measurements of monomethylmercury $\left(\mathrm{CH}_{3} \mathrm{Hg}^{+}\right)$ by isotope dilution ICP-MS and detection of species transformation," Fresenius Journal of Analytical Chemistry 358, 378-385.

Hintelmann, H., Keppel-Jones, K., and Evans, R. D. (2000). "Constants of mercury methylation and demethylation rates in sediments and comparison of tracer and ambient mercury availability," Environmental Toxicology and Chemistry 19, 2204-2211.

Hintelmann, H., and Ogrinc, N. (2003). "Determination of stable mercury isotopes by ICP/MS and their application in environmental studies," Biogeochemistry of environmentally important trace elements, ACS Symposium Series 835, Y. Cai and C. O. Braids, ed., American Chemical Society, Washington, DC, 321-338.

Horvat, M., Bloom, N. S., and Liang, L. (1993). "Comparison of distillation with other current isolation methods for the determination of methyl mercury compounds in low level environmental samples," Analytica Chimica Acta $281,135-152$.

Hudson, R. J. M., Gherini, S. A., Watras, C. J., and Porcella, D. B. (1994). "Modeling the biogeochemical cycle of mercury in lakes: The mercury cycling model (MCM) and its application to the MTL study lakes." Mercury pollution: Integration and synthesis, C. J. Watras and J. W. Huckabee, ed., Lewis Publishers, 473-523.

Kannan, K., Smith, R. G., Jr., Lee, R. F., Windom, H. L., Heitmuller, P. T., Macauley, J. M., and Summers, J. K. (1998). "Distribution of total mercury 
and methyl mercury in water, sediment, and fish from south Florida estuaries," Archives of Environmental Contamination and Toxicology 34, 109-118.

King, J. K., Gladden, J. B., Harmon, S. M., and Fu, T. T. (2001). "Mercury removal, methylmercury formation, and sulfate-reducing bacteria profiles in wetland mesocosms containing gypsum-amended sediments," WSRC-TR2001-00063.

Kwak, T. J., and Zedler, J. B. (1997). "Food web analysis of southern California coastal wetlands using multiple stable isotopes," Oecologia 110, 262-277.

Lambers, H., Chapin, F. S. III, and Pons, T. L. (1998). "Mineral nutrition," Plant physiological ecology. Chapter 6, Springer, 239-263.

Lee, C. R., et al. (2000). "Field survey of contaminated concentrations in existing wetlands in the San Francisco Bay area," ERDC/EL SR-00-15, U.S. Army Engineer Research and Development Center, Vicksburg, MS.

Leonard, E. N., Cotter, A. M., and Ankley, G. T. (1996). "Modified diffusion method for analysis of acid volatile sulfide and simultaneously extractable metals in freshwater sediments," Environmental Toxicology and Chemistry $15,1479-81$.

Light, T. S. (1972). "Standard solution for redox potential measurements," Analytical Chemistry 44, 1038-1039.

Lindberg, S. E., Dong, W., and Meyers, T. (2002). "Transpiration of gaseous elemental mercury through vegetation in a subtropical wetland in Florida," Atmospheric Environment 36, 5207-5219.

Lindberg, S. E., Dong, W., Meyers, T., and Chanton, J. (2005). "A mechanism for bimodal emission of gaseous mercury from aquatic macrophytes," Atmospheric Environment 39, 1289-1301.

Marvin-DiPasquale, M. C., Agee, J. L., Bouse, R. M., and Jaffe, B. E. (2003). "Microbial cycling of mercury in contaminated pelagic and wetland sediments of San Pablo Bay, California," Environmental Geology 43, 260-267.

Mason, R. P., Reinfelder, J. R., and Morel, F. M. M. (1996). "Uptake, toxicity, and trophic transfer of mercury in a coast diatom," Environmental Science and Technology 30, 1835-1845.

McFarland, V. A., Clarke, J. U., Lutz, C. H., and MacMillan, D. K. (2002). "Mercury concentrations bordering the Hamilton Army Air Field remediation site: September 2001," Report to USACE District, San Francisco, by U.S. Army Engineer Research and Development Center, Vicksburg, MS.

McFarland, V. A., Clarke, J. U., Lutz, C. H., and MacMillan, D. K. (2003a). "Mercury concentrations bordering the Hamilton Army Air Field remediation site: February, 2003. Wet season - dry season contrast," Draft Report to 
USACE District, San Francisco, by U.S. Army Engineer Research and Development Center, Vicksburg, MS.

McFarland, V. A., and Lee, C. R. (2002). "Dredging-related mercury issues in the San Francisco Bay-Delta Region," prepared for the USACE District, San Francisco, by the U.S. Army Engineer Research and Development Center, Vicksburg, MS.

McFarland, V. A., Lutz, C. H., Bednar, A. H., Jones, R. P., Fredrickson, H., Ray, G. L., Lotufo, G. R., Kiker, G. A., Price, R. A., Sturgis, T., and Best, E. (2003b). "Project management plan for detailed characterization of existing mercury and methylmercury contamination bordering the Hamilton Army Airfield wetlands restoration site, April - September 2003," Prepared for USACE District, San Francisco, by U.S. Army Engineer Research and Development Center, Vicksburg, MS.

Mills, A. L. (1997). "Metal requirements and tolerance." Manual of environmental microbiology, C. J. Hurst, G. R. Knudsen, M. J. McInerney, L. D. Stetzenbech, and M. V. Walter, ed., American Society for Microbiology, Washington, DC, 349-357.

Millward, R. N., Bridges, T. S, Ghosh, U., Luthy, R. G., and Zimmerman, J. R. (2004). "Addition of granular activated carbon (GAC) and coke to reduce PCB bioavailability in sediments: Bioaccumulation and toxicity tests," Environmental Science and Technology, 39, 2880-2887.

Morel, F. M. M., Kraepiel, A. M., and Amyoy, M. (1998). "The chemical cycle and bioaccumulation of mercury," Annual Review of Ecology and Systematics 29, 543-566.

Onuf, C. P. (1987). "The ecology of Mugu Lagoon, California: An estuarine profile," Biological Report 85, U.S. Fish and Wildlife Service, 122 pp.

Patrick, W. H., Jr. (1958). "Modification of method of particle size analysis," Soil Science Society of America Proceedings 22, 366-367.

Pethick, J. S. (1992). "Saltmarsh geomorphology," Saltmarshes: Morphodynamics, conservation and engineering significance. J. R. L. Allen and K. Pye, ed., Cambridge University, New York.

Philip Williams and Associates. (1998). "Conceptual design for tidal wetland restoration for the Hamilton Airfield focused feasibility study," Vol. 1, prepared for IT Corporation, $103 \mathrm{pp}$.

Pinkart, H. C., Ringelberg, D. B., Piceno, Y. M., MacNaughton, S. J., and White, D. C. (2002). "Biochemical approaches to biomass measurements and community structure analysis." Manual of environmental microbiology. 2nd ed., C. J. Hurst, R. Crawford, G. Knudsen, M. J. McInerney, and L. D. Stetzenbach, ed., American Society of Microbiology, Washington, DC, 101-113. 
Rogers, D. W. (1994). "You are what you eat and a little bit more: Bioenergeticsbased models of methylmercury accumulation in fish revisited." Mercury pollution: Integration and synthesis, C. J. Watras and J. W. Huckabee, ed., Lewis Publishers, 473-523.

Roulet, M., Guimaraes, J.-R. D., and Lucotte, M. (2001). "Methylmercury production and accumulation in sediments and soils of an Amazonian floodplain - Effect of seasonal inundation," Water Air and Soil Pollution 128, 41-60.

San Francisco Bay Area Wetlands Ecosystem Goals Project. (1999). "Baylands ecosystem habitat goals," 1st reprint, U.S. Environmental Protection Agency, San Francisco, CA, San Francisco Bay Regional Water Quality Control Board, Oakland, CA.

SAS Institute, Inc. (2001). The SAS ${ }^{\circledR}$ system for Windows, release 8.02. Cary, $\mathrm{NC}$.

Schlesinger, W. H. (1991). Biogeochemistry: An analysis of global change. Academic Press, San Diego, CA.

Shoemaker, L. H. (2003). "Fixing the $F$ test for equal variances," The American Statistician 57, 105-114.

St. Louis, V. L., Rudd, J. W. M., Kelly, C. A., Beaty, K. G., Bloom, N. S., and Flett, R. J. (1994). "The importance of wetlands as sources of methyl mercury to boreal forest ecosystems," Canadian Journal of Fisheries and Aquatic Sciences 51, 1065-1076.

St. Louis, V. L., Rudd, J. W. M., Kelly, C. A., Beaty, K. G., Flett, R. J., and Roulet, N. T. (1996). "Production and loss of total mercury from boreal forest catchments containing different types of wetlands," Environmental Science and Technology 30, 2719-2729.

St. Louis, V. L., Rudd, J. W. M., Kelly, C. A., Hall, B. D., Rolfhus, K. R., Scott, K. J., Lindberg, S. E., and Dong, W. (2001). "Importance of the forest canopy to fluxes of methyl mercury and total mercury to boreal ecosystems," Environmental Science and Technology 35, 3089-3098.

Tsui, M. T. K., and Wang, W. (2004). "Uptake and elimination routes of inorganic mercury and methylmercury in Daphnia magna," Environmental Science and Technology 38, 808-816.

Ullrich, S. M., Tanton, T. W., and Abdrashitova, S. A. (2001). "Mercury in the aquatic environment: A review of factors affecting methylation," Critical Reviews in Environmental Science and Technology 31, 241-293.

U.S. Environmental Protection Agency. (1989). "Guidance manual: Bedded sediment bioaccumulation tests," EPA/600/x-89/302, ERL-N, Pacific Ecosystems Branch, Newport, OR. 
U.S. Environmental Protection Agency. (1992a). "Acid digestion of sediments, sludges, and soils, method 3050B, test methods for the analysis of solid waste, physical/chemical methods," Update II, 3rd ed.

U.S. Environmental Protection Agency. (1992b). "Inductively coupled plasmaatomic emission spectrometry, method 6010B, test methods for the analysis of solid waste, physical/chemical methods," Update II, 3rd ed.

U.S. Environmental Protection Agency. (1992c). "Mercury in solid or semisolid waste (manual cold-vapor technique), method 7471A, test methods for evaluating solid waste methods, SW-846," Update II, 3rd ed.

U.S. Environmental Protection Agency. (1994). "Mercury in solid or semi-solid waste (manual cold-vapor technique)," Washington, DC, http://www.epa.gov/epaoswer/hazwaste/test/pdfs/7471a.pdf.

U.S. Environmental Protection Agency. (1997). "Mercury study report to Congress. Volume VIII. An evaluation of mercury control technologies and costs," EPA 452/R-97-010, Washington, DC.

U.S. Fish and Wildlife Service. (2003). "Evaluation of the Clean Water Act Section 304(a) human health criterion for methylmercury: Protectiveness for threatened and endangered wildlife in California," Sacramento Fish and Wildlife Office, Environmental Contaminants Division. Sacramento, CA.

Van Handel, E. (1985). "Rapid determination of total lipids in mosquitoes," Journal of American Mosquito Control Association 1, 302-304.

Vitaliano, J. J., and Bejda, A. J. (2001). "Age, growth, and allometric relationships of ribbed mussels (Geuken demissa)," NOAA Technical Memo 167, http://nefsc.noaa.gov/nefsc/publications/tm/tm167/tm167p5.htm

Windham, L., Weis, J. S., and Weis, P. (2001). "Patterns and processes of mercury release from leaves of two dominant salt marsh macrophytes, Phragmites australis and Spartina alterniflora," Estuaries 24, 787-795.

Winfield, T. P. (1980). "Dynamics of carbon and nitrogen in a southern California salt marsh," Ph.D. diss., University of California Riverside, and San Diego State University, $76 \mathrm{pp}$.

Winfrey, M. R., and Rudd, J. W. M. (1990). "Environmental factors affecting the formation of methylmercury in low pH lakes," Environmental Toxicology and Chemistry 9, 853-869.

Zedler, J. B., Winfield, T., and Williams, P. (1980). "Salt marsh productivity with natural and altered tidal circulation," Oecologia 44, 236-240.

Zimmerman, J. R., Ghosh, U., Luthy, R. G., Millward, R. N., and Bridges, T. S. (2004). "Addition of carbon sorbents to reduce bioavailability of PAH and PCB in marine sediments; Physicochemical tests," Environmental Science and Technology 38, 5458-5464. 
Zimmerman, J. R., Ghosh, U., Millward, R. N., Bridges, T. S., and Luthy, R. G. (2004). "Addition of carbon sorbents to reduce PAH and PCB bioavailability in marine sediments; Physicochemical tests," Environmental Science and Technology, 38 (15). 


\section{Appendix A Addendum to Chapter 5}

\section{Table A1}

Sediment Quality Characteristics of Bel Marin (BM-50a; $n=1)$ and HAAF Upland (SM10U; $n=1$ ) Soil/Sediment Cores, Mean (SD)

\begin{tabular}{|c|c|c|c|c|c|c|c|}
\hline Depth Section, cm & Eh, $\mathrm{mV}$ & AVS, $\mu g / g$ & TOC, $\%$ & Sand, $\%$ & Silt, \% & Clay, \% & Fines, $\%$ \\
\hline \multicolumn{8}{|c|}{ SM-10U } \\
\hline $0-7.6$ & -- & 0.53 & 19 & -- & -- & -- & -- \\
\hline $7.6-10.2$ & -- & $<0.22$ & 17 & -- & -- & -- & -- \\
\hline $10.2-14.0$ & -- & $<0.23$ & 13 & 13 & 58 & 29 & 0.87 \\
\hline $14.0-17.8$ & -- & 2.7 & 7.8 & 5.9 & 50 & 45 & 0.94 \\
\hline $17.8-24.1$ & -- & 9.4 & 7.5 & 0.96 & 61 & 38 & 0.99 \\
\hline $24.1-30.5$ & -- & 74 & 3.9 & 0.58 & 51 & 48 & 0.99 \\
\hline $30.5-40.6$ & -- & 1600 & 3.3 & 0.37 & 55 & 45 & 1 \\
\hline \multicolumn{8}{|c|}{ BM-50a } \\
\hline $0-2.5$ & 516 & $<0.06$ & 1.7 & 13 & 45 & 43 & 0.87 \\
\hline $2.5-5.1$ & 454 & 0.09 & 1.6 & 6.5 & 54 & 39 & 0.94 \\
\hline $5.1-7.6$ & 440 & 0.43 & 1.7 & 8.8 & 50 & 41 & 0.91 \\
\hline $7.6-10.2$ & 265 & 0.71 & 1.7 & 23 & 38 & 40 & 0.78 \\
\hline $10.2-12.7$ & 136 & 8.7 & 1.8 & 3.5 & 52 & 45 & 0.96 \\
\hline $12.7-15.2$ & 141 & 1100 & 1.9 & 6.1 & 52 & 42 & 0.94 \\
\hline
\end{tabular}




\begin{tabular}{|c|c|c|c|c|c|c|c|}
\hline \multicolumn{8}{|c|}{$\begin{array}{l}\text { Table A2 } \\
\text { Major and Trace Elements of Bay Edge (SM-1, SM-10) and Reference (R-44) } \\
\text { Soil/Sediment Cores, Mean (SD) }\end{array}$} \\
\hline Depth Section, cm & Al, \% & $\mathrm{Fe}, \%$ & Cs, $\mu g / g^{-1}$ & $\mathrm{Li}, \mu \mathrm{g} / \mathrm{g}^{-1}$ & $M n, \mu g / g^{-1}$ & $P, \mu g / g^{-1}$ & Se, $\mu \mathrm{g} / \mathrm{g}^{-1}$ \\
\hline \multicolumn{8}{|c|}{ SM-1 } \\
\hline $0-2.5$ & $2.9(0.3)$ & $4.3(0.2)$ & $3.2(0.3)$ & $33(3)$ & $430(66)$ & $720(120)$ & $1.0(0.1)$ \\
\hline $2.5-5.1$ & $3.0(0.4)$ & $4.5(0.1)$ & $3.2(0.3)$ & $36(4)$ & $480(230)$ & $590(180)$ & $1.1(0.1)$ \\
\hline $5.1-7.6$ & $3.2(0.2)$ & $4.4(0.3)$ & $3.3(0.3)$ & $38(3)$ & $410(93)$ & $520(120)$ & $1.1(0.1)$ \\
\hline $7.6-10.2$ & $3.3(0.3)$ & $4.5(0.1)$ & $3.3(0.2)$ & $40(3)$ & $400(84)$ & $630(320)$ & $1.1(0.1)$ \\
\hline $10.2-12.7$ & $3.5(0.2)$ & $4.5(0.1)$ & $3.4(0.2)$ & $42(2)$ & $430(97)$ & $500(30)$ & $1.1(0.1)$ \\
\hline $12.7-15.2$ & $3.8(0.3)$ & $4.4(0.3)$ & $3.5(0.2)$ & $44(3)$ & $450(110)$ & $490(10)$ & $1.0(0.1)$ \\
\hline \multicolumn{8}{|c|}{ SM-10 } \\
\hline $0-2.5$ & $2.6(0.4)$ & $3.5(0.4)$ & $2.6(0.3)$ & $29(3)$ & $440(120)$ & $790(160)$ & $0.84(0.15)$ \\
\hline $2.5-5.1$ & $2.5(0.4)$ & $3.5(0.3)$ & $2.6(0.2)$ & $29(4)$ & $320(91)$ & $510(61)$ & $0.82(0.09)$ \\
\hline $5.1-7.6$ & $2.8(0.3)$ & $3.8(0.1)$ & $2.6(0.4)$ & $33(3)$ & $380(94)$ & $530(210)$ & $0.80(0.08)$ \\
\hline $7.6-10.2$ & $3.0(0.3)$ & $4.1(0.2)$ & $2.9(0.2)$ & $37(2)$ & $450(59)$ & $480(14)$ & $0.84(0.09)$ \\
\hline $10.2-12.7$ & $3.2(0.1)$ & $4.2(0.1)$ & $2.9(0.2)$ & $39(1)$ & $510(66)$ & $470(25)$ & $0.80(0.07)$ \\
\hline $12.7-15.2$ & $3.4(0.0)$ & $4.2(0.1)$ & $3.0(0.3)$ & $41(1)$ & $490(59)$ & $470(29)$ & $0.76(0.05)$ \\
\hline \multicolumn{8}{|c|}{ R-44 } \\
\hline $0-2.5$ & $3.6(0.3)$ & $4.8(0.6)$ & $3.7(0.2)$ & $41(2)$ & $370(100)$ & $740(190)$ & $0.93(0.08)$ \\
\hline $2.5-5.1$ & $3.8(0.3)$ & $4.6(0.4)$ & $3.7(0.1)$ & $43(2)$ & $350(80)$ & $690(120)$ & $1.0(0.1)$ \\
\hline $5.1-7.6$ & $3.7(0.2)$ & $4.4(0.3)$ & $3.5(0.1)$ & $42(1)$ & $310(29)$ & $650(120)$ & $0.97(0.06)$ \\
\hline $7.6-10.2$ & $3.8(0.3)$ & $5.0(0.4)$ & $3.5(0.1)$ & $43(2)$ & $410(160)$ & $660(200)$ & $0.98(0.11)$ \\
\hline $10.2-12.7$ & $3.8(0.4)$ & $5.1(0.3)$ & $3.6(0.1)$ & $43(2)$ & $450(88)$ & $670(220)$ & $1.1(0.1)$ \\
\hline $12.7-15.2$ & $3.8(0.3)$ & $4.8(0.4)$ & $3.54(0.2)$ & $43(2)$ & $490(62)$ & $650(210)$ & $0.94(0.12)$ \\
\hline
\end{tabular}

\section{Table A3}

Major and Trace Elements of Bel Marin (BM-50a; $n=1)$ and HAAF Upland (SM-10U; $n=$ 1) Soil/Sediment Cores, Mean (SD)

\begin{tabular}{|c|c|c|c|c|c|c|c|}
\hline Depth Section, cm & Al, $\%$ & $\mathrm{Fe}, \%$ & Cs, $\mu \mathrm{g} / \mathrm{g}^{-1}$ & $L \mathbf{L i}, \mu \mathrm{g} / \mathrm{g}^{-1}$ & $M n, \mu g / g^{-1}$ & $P, \mu g / g^{-1}$ & Se, $\mu g / g^{-1}$ \\
\hline \multicolumn{8}{|c|}{ SM-10U } \\
\hline $0-7.6$ & 2.2 & 3.9 & 2.1 & 22 & 5300 & 1600 & 1.5 \\
\hline $7.6-10.2$ & 2.7 & 4.5 & 2.6 & 29 & 1900 & 1300 & 2.1 \\
\hline $10.2-14.0$ & 2.6 & 5.6 & 2.7 & 29 & 540 & 1600 & 1.6 \\
\hline $14.0-17.8$ & 3.4 & 4.6 & 3.2 & 36 & 260 & 1200 & 1.5 \\
\hline $17.8-24.1$ & 3 & 3.5 & 2.9 & 34 & 220 & 820 & 1.4 \\
\hline $24.1-30.5$ & 3.5 & 3.8 & 3.2 & 39 & 240 & 790 & 1.2 \\
\hline $30.5-40.6$ & 3.8 & 4.3 & 3.3 & 42 & 280 & 970 & 1.1 \\
\hline \multicolumn{8}{|c|}{ BM-50a } \\
\hline $0-2.5$ & 4.4 & 4.9 & 3.5 & 42 & 440 & 950 & 1.0 \\
\hline $2.5-5.1$ & 3.7 & 4.0 & 3.4 & 37 & 270 & 770 & 0.96 \\
\hline $5.1-7.6$ & 4.1 & 4.3 & 3.4 & 40 & 270 & 740 & 0.96 \\
\hline $7.6-10.2$ & 3.6 & 4.1 & 3.5 & 38 & 250 & 790 & 1.1 \\
\hline $10.2-12.7$ & 3.8 & 4.3 & 3.6 & 39 & 260 & 980 & 1.0 \\
\hline $12.7-15.2$ & 3.7 & 4.2 & 3.3 & 40 & 300 & 860 & 0.91 \\
\hline
\end{tabular}




\begin{tabular}{|c|c|c|c|c|c|c|c|}
\hline \multicolumn{8}{|c|}{$\begin{array}{l}\text { Table A4 } \\
\text { THg Statistical Analysis by Depth Profile }\end{array}$} \\
\hline Location & Depth, cm & $\mathbf{N}$ & Median, ug g ${ }^{-1}$ & Mean of Ranks & Tukey Ranking* & Mean, ug g $^{-1}$ & St. Dev., ug g ${ }^{-1}$ \\
\hline \multirow[t]{6}{*}{ SM-1 } & $0-2.5$ & 5 & 0.33 & 12 & $\mathrm{BC}$ & 0.33 & 0.06 \\
\hline & $2.5-5.1$ & 5 & 0.34 & 8.9 & $\mathrm{C}$ & 0.33 & 0.04 \\
\hline & $5.1-7.6$ & 5 & 0.36 & 11 & $\mathrm{BC}$ & 0.33 & 0.05 \\
\hline & $7.6-10.2$ & 5 & 0.36 & 14 & $A B C$ & 0.35 & 0.03 \\
\hline & $10.2-12.7$ & 5 & 0.41 & 23 & $A B$ & 0.40 & 0.03 \\
\hline & $12.7-15.2$ & 5 & 0.42 & 25 & $A$ & 0.41 & 0.04 \\
\hline \multirow[t]{6}{*}{ SM-10 } & $0-2.5$ & 5 & 0.32 & 8.0 & $A$ & 0.33 & 0.04 \\
\hline & $2.5-5.1$ & 5 & 0.35 & 12 & $A$ & 0.34 & 0.04 \\
\hline & $5.1-7.6$ & 5 & 0.35 & 16 & $A$ & 0.36 & 0.04 \\
\hline & $7.6-10.2$ & 5 & 0.35 & 20 & $A$ & 0.38 & 0.04 \\
\hline & $10.2-12.7$ & 5 & 0.34 & 14 & $A$ & 0.35 & 0.03 \\
\hline & $12.7-15.2$ & 5 & 0.38 & 22 & $A$ & 0.38 & 0.02 \\
\hline \multirow[t]{6}{*}{$\mathrm{R}-44$} & $0-2.5$ & 5 & 0.29 & 10 & A & 0.32 & 0.04 \\
\hline & $2.5-5.1$ & 5 & 0.32 & 15 & $A$ & 0.34 & 0.04 \\
\hline & $5.1-7.6$ & 5 & 0.34 & 17 & $A$ & 0.35 & 0.04 \\
\hline & $7.6-10.2$ & 5 & 0.34 & 14 & $A$ & 0.34 & 0.05 \\
\hline & $10.2-12.7$ & 5 & 0.37 & 17 & $A$ & 0.37 & 0.08 \\
\hline & $12.7-15.2$ & 5 & 0.43 & 20 & $A$ & 0.41 & 0.10 \\
\hline
\end{tabular}

\begin{tabular}{|c|c|c|c|c|c|c|c|}
\hline \multicolumn{8}{|c|}{$\begin{array}{l}\text { Table A5 } \\
\text { MeHg Statistical Analysis by Depth Profile }\end{array}$} \\
\hline Location & Depth, cm & $\mathbf{N}$ & Median, ug kg ${ }^{-1}$ & Mean of Ranks & Tukey Ranking* & Mean, ug kg ${ }^{-1}$ & St. Dev., ug kg ${ }^{-1}$ \\
\hline \multirow[t]{6}{*}{ SM-1 } & $0-2.5$ & 5 & 3.4 & 18 & A & 3.3 & 3.2 \\
\hline & $2.5-5.1$ & 5 & 2.2 & 16 & $A$ & 2.2 & 2.0 \\
\hline & $5.1-7.6$ & 5 & 4.2 & 20 & $A$ & 0.99 & 1.2 \\
\hline & $7.6-10.2$ & 5 & 1.5 & 13 & A & 1.1 & 1.1 \\
\hline & $10.2-12.7$ & 5 & 1.0 & 14 & A & 0.84 & 1.2 \\
\hline & $12.7-15.2$ & 5 & 0.54 & 11 & A & 0.34 & 0.27 \\
\hline \multirow[t]{6}{*}{ SM-10 } & $0-2.5$ & 5 & 5.2 & 25 & A & 4.4 & 3.6 \\
\hline & $2.5-5.1$ & 5 & 3.9 & 20 & $A B$ & 2.9 & 2.3 \\
\hline & $5.1-7.6$ & 5 & 1.4 & 18 & $A B$ & 1.2 & 1.1 \\
\hline & $7.6-10.2$ & 5 & 0.31 & 11 & $\mathrm{~B}$ & 0.28 & 0.26 \\
\hline & $10.2-12.7$ & 5 & 0.23 & 11 & $\mathrm{~B}$ & 0.22 & 0.13 \\
\hline & $12.7-15.2$ & 5 & 0.15 & 9 & $\mathrm{~B}$ & 0.16 & 0.16 \\
\hline \multirow[t]{6}{*}{$\mathrm{R}-44$} & $0-2.5$ & 5 & 4.2 & 20 & $A$ & 3.6 & 3.7 \\
\hline & $2.5-5.1$ & 5 & 3.4 & 18 & $A$ & 2.0 & 1.5 \\
\hline & $5.1-7.6$ & 5 & 2.2 & 16 & $A$ & 3.9 & 3.1 \\
\hline & $7.6-10.2$ & 5 & 1.0 & 14 & A & 2.6 & 3.8 \\
\hline & $10.2-12.7$ & 5 & 1.5 & 13 & A & 1.8 & 1.9 \\
\hline & $12.7-15.2$ & 5 & 0.54 & 11 & $A$ & 0.91 & 0.76 \\
\hline
\end{tabular}




\begin{tabular}{|c|c|c|c|c|c|c|c|}
\hline \multicolumn{8}{|c|}{$\begin{array}{l}\text { Table A6 } \\
\text { Statistical Analysis of Phosphorus (P) by Depth Profile }\end{array}$} \\
\hline Location & Depth, cm & $\mathbf{N}$ & Median, ug g ${ }^{-1}$ & Mean of Ranks & Tukey Ranking* & Mean, ug g ${ }^{-1}$ & St. Dev., ug g ${ }^{-1}$ \\
\hline \multirow[t]{6}{*}{ SM-1 } & $0-2.5$ & 5 & 710 & 25 & $A$ & 720 & 120 \\
\hline & $2.5-5.1$ & 5 & 530 & 16 & $A$ & 590 & 180 \\
\hline & $5.1-7.6$ & 5 & 500 & 12 & $A$ & 520 & 110 \\
\hline & $7.6-10.2$ & 5 & 490 & 15 & $A$ & 630 & 320 \\
\hline & $10.2-12.7$ & 5 & 500 & 14 & $A$ & 500 & 29 \\
\hline & $12.7-15.2$ & 5 & 480 & 10 & $A$ & 490 & 10 \\
\hline \multirow[t]{6}{*}{ SM-10 } & $0-2.5$ & 5 & 850 & 27 & $A$ & 790 & 160 \\
\hline & $2.5-5.1$ & 5 & 510 & 19 & $A B$ & 510 & 61 \\
\hline & $5.1-7.6$ & 5 & 460 & 10 & $B$ & 530 & 210 \\
\hline & $7.6-10.2$ & 5 & 470 & 13 & $\mathrm{~B}$ & 480 & 14 \\
\hline & $10.2-12.7$ & 5 & 470 & 11 & $\mathrm{~B}$ & 470 & 25 \\
\hline & $12.7-15.2$ & 5 & 480 & 13 & $B$ & 470 & 29 \\
\hline \multirow[t]{6}{*}{ R-44 } & $0-2.5$ & 5 & 850 & 19 & A & 740 & 190 \\
\hline & $2.5-5.1$ & 5 & 740 & 17 & $A$ & 690 & 120 \\
\hline & $5.1-7.6$ & 5 & 610 & 17 & $A$ & 650 & 120 \\
\hline & $7.6-10.2$ & 5 & 530 & 15 & $A$ & 660 & 200 \\
\hline & $10.2-12.7$ & 5 & 540 & 14 & $A$ & 670 & 220 \\
\hline & $12.7-15.2$ & 5 & 510 & 12 & $A$ & 650 & 210 \\
\hline
\end{tabular}

\section{Table A7
Statistical Analysis of Manganese (Mn) by Depth Profile}

\begin{tabular}{|c|c|c|c|c|c|c|c|}
\hline Location & Depth, cm & $\mathbf{N}$ & Median, ug g $^{-1}$ & Mean of Ranks & Tukey Ranking* & Mean, ug g ${ }^{-1}$ & St. Dev., ug g ${ }^{-1}$ \\
\hline \multirow[t]{6}{*}{ SM-1 } & $0-2.5$ & 5 & 420 & 15 & A & 430 & 66 \\
\hline & $2.5-5.1$ & 5 & 380 & 14 & $A$ & 480 & 230 \\
\hline & $5.1-7.6$ & 5 & 420 & 14 & $A$ & 410 & 93 \\
\hline & $7.6-10.2$ & 5 & 410 & 14 & $A$ & 400 & 84 \\
\hline & $10.2-12.7$ & 5 & 470 & 18 & A & 430 & 97 \\
\hline & $12.7-15.2$ & 5 & 480 & 19 & $A$ & 450 & 110 \\
\hline \multirow[t]{6}{*}{ SM-10 } & $0-2.5$ & 5 & 423 & 16 & $A B$ & 440 & 120 \\
\hline & $2.5-5.1$ & 5 & 285 & 6.6 & $B$ & 320 & 91 \\
\hline & $5.1-7.6$ & 5 & 346 & 10 & $A B$ & 380 & 94 \\
\hline & $7.6-10.2$ & 5 & 468 & 17 & $A B$ & 450 & 59 \\
\hline & $10.2-12.7$ & 5 & 544 & 22 & $A$ & 510 & 66 \\
\hline & $12.7-15.2$ & 5 & 458 & 22 & $A$ & 490 & 59 \\
\hline \multirow[t]{6}{*}{$\mathrm{R}-44$} & $0-2.5$ & 5 & 340 & 15 & $A B$ & 370 & 100 \\
\hline & $2.5-5.1$ & 5 & 320 & 11 & $A B$ & 350 & 80 \\
\hline & $5.1-7.6$ & 5 & 290 & 7.0 & B & 310 & 29 \\
\hline & $7.6-10.2$ & 5 & 360 & 14 & $A B$ & 410 & 160 \\
\hline & $10.2-12.7$ & 5 & 430 & 22 & $A$ & 450 & 88 \\
\hline & $12.7-15.2$ & 5 & 500 & 24 & $A$ & 490 & 62 \\
\hline
\end{tabular}




\begin{tabular}{|c|c|c|c|c|c|c|c|}
\hline \multicolumn{8}{|c|}{$\begin{array}{l}\text { Table A8 } \\
\text { Statistical Analysis of Total Organic Carbon (\% TOC) by Depth Profile }\end{array}$} \\
\hline Location & Depth, cm & $\mathbf{N}$ & Median, ug g ${ }^{-1}$ & Mean of Ranks & Tukey Ranking* & Mean, ug g ${ }^{-1}$ & St. Dev., ug g ${ }^{-1}$ \\
\hline \multirow[t]{6}{*}{ SM-1 } & $0-2.5$ & 5 & 4.6 & 22 & $A B$ & 4.4 & 0.9 \\
\hline & $2.5-5.1$ & 5 & 4.4 & 24 & $A$ & 4.5 & 0.8 \\
\hline & $5.1-7.6$ & 5 & 4.3 & 21 & $A B$ & 4.2 & 0.5 \\
\hline & $7.6-10.2$ & 5 & 3.4 & 14 & $\mathrm{BC}$ & 3.6 & 0.5 \\
\hline & $10.2-12.7$ & 5 & 3.3 & 8.6 & $\mathrm{C}$ & 3.2 & 0.7 \\
\hline & $12.7-15.2$ & 5 & 2.9 & 4.2 & $\mathrm{C}$ & 3.0 & 1.2 \\
\hline \multirow[t]{6}{*}{ SM-10 } & $0-2.5$ & 5 & 4.6 & 22 & $A B$ & 4.7 & 1.1 \\
\hline & $2.5-5.1$ & 5 & 4.4 & 24 & $A$ & 4.7 & 0.5 \\
\hline & $5.1-7.6$ & 5 & 4.3 & 21 & $A B$ & 4.2 & 0.7 \\
\hline & $7.6-10.2$ & 5 & 3.4 & 14 & $\mathrm{BC}$ & 3.6 & 0.5 \\
\hline & $10.2-12.7$ & 5 & 3.3 & 8.6 & $\mathrm{C}$ & 3.2 & 0.3 \\
\hline & $12.7-15.2$ & 5 & 2.9 & 4.2 & $\mathrm{C}$ & 2.9 & 0.1 \\
\hline \multirow[t]{6}{*}{ R-44 } & $0-2.5$ & 5 & 2.9 & 9.6 & A & 3.1 & 0.4 \\
\hline & $2.5-5.1$ & 5 & 3.5 & 16 & $A$ & 3.6 & 0.7 \\
\hline & $5.1-7.6$ & 5 & 3.5 & 17 & $A$ & 3.7 & 0.8 \\
\hline & $7.6-10.2$ & 5 & 3.9 & 18 & $A$ & 3.7 & 0.6 \\
\hline & $10.2-12.7$ & 5 & 3.8 & 20 & $A$ & 3.8 & 0.6 \\
\hline & $12.7-15.2$ & 5 & 3.0 & 12 & $A$ & 3.3 & 0.5 \\
\hline
\end{tabular}

\section{Table A9 \\ Statistical Analysis of Redox Potential $\left(E_{h}\right)$ by Depth Profile}

\begin{tabular}{|c|c|c|c|c|c|c|c|}
\hline Location & Depth, cm & $\mathbf{N}$ & Median, mV & Mean of Ranks & Tukey Ranking* & Mean, mV & St. Dev., mV \\
\hline \multirow[t]{6}{*}{ SM-1 } & $0-2.5$ & 4 & 70 & 18 & A & 52 & 81 \\
\hline & $2.5-5.1$ & 4 & -98 & 14 & $A B$ & -87 & 42 \\
\hline & $5.1-7.6$ & 4 & -124 & 7.9 & $B$ & -131 & 34 \\
\hline & $7.6-10.2$ & 2 & -118 & 11 & $A B$ & -118 & 1.3 \\
\hline & $10.2-12.7$ & 4 & -151 & 5.0 & $B$ & -152 & 19 \\
\hline & $12.7-15.2$ & 2 & -140 & 5.3 & $B$ & -140 & 0.4 \\
\hline \multirow[t]{6}{*}{ SM-10 } & $0-2.5$ & 4 & 296 & 24 & $A$ & 311 & 183 \\
\hline & $2.5-5.1$ & 5 & 352 & 23 & $A B$ & 268 & 223 \\
\hline & $5.1-7.6$ & 5 & 70 & 18 & $A B C$ & 93 & 176 \\
\hline & $7.6-10.2$ & 5 & -63 & 12 & $B C$ & -26 & 146 \\
\hline & $10.2-12.7$ & 5 & -83 & 8.2 & $\mathrm{C}$ & -100 & 50 \\
\hline & $12.7-15.2$ & 5 & -135 & 6.6 & $\mathrm{C}$ & -117 & 31 \\
\hline \multirow[t]{6}{*}{$\mathrm{R}-44$} & $0-2.5$ & 5 & 368 & 25 & $A$ & 348 & 42 \\
\hline & $2.5-5.1$ & 5 & 266 & 21 & $A B$ & 284 & 86 \\
\hline & $5.1-7.6$ & 5 & 255 & 19 & $A B$ & 187 & 201 \\
\hline & $7.6-10.2$ & 5 & 40 & 14 & $A B C$ & 84 & 199 \\
\hline & $10.2-12.7$ & 5 & -80 & 10 & $B C$ & -12 & 143 \\
\hline & $12.7-15.2$ & 5 & -135 & 5.2 & $C$ & -110 & 56 \\
\hline
\end{tabular}




\begin{tabular}{|c|c|c|c|c|c|c|c|}
\hline \multicolumn{8}{|c|}{$\begin{array}{l}\text { Table A10 } \\
\text { Statistical Analysis of Acid-Base Characteristics }(\mathrm{pH}) \text { by Depth Profile }\end{array}$} \\
\hline Location & Depth, cm & $\mathbf{N}$ & Median, mV & Mean of Ranks & Tukey Ranking* & Mean, $\mathrm{mV}$ & St. Dev., mV \\
\hline \multirow[t]{6}{*}{ SM-1 } & $0-2.5$ & 5 & 6.4 & 4.3 & C & 6.3 & 0.2 \\
\hline & $2.5-5.1$ & 5 & 6.4 & 5.0 & $\mathrm{BC}$ & 6.4 & 0.1 \\
\hline & $5.1-7.6$ & 5 & 6.6 & 11 & $A B$ & 6.6 & 0.1 \\
\hline & $7.6-10.2$ & 3 & 6.7 & 14 & $A$ & 6.6 & 0.1 \\
\hline & $10.2-12.7$ & 4 & 6.7 & 16 & $A$ & 6.7 & 0.1 \\
\hline & $12.7-15.2$ & 1 & 6.8 & 18 & $A$ & 6.8 & 0.2 \\
\hline \multirow[t]{6}{*}{ SM-10 } & $0-2.5$ & 4 & 5.4 & 9.4 & $\mathrm{BC}$ & 5.4 & 0.3 \\
\hline & $2.5-5.1$ & 5 & 5.1 & 7.0 & $\mathrm{C}$ & 5.0 & 0.7 \\
\hline & $5.1-7.6$ & 5 & 5.1 & 9.1 & $B C$ & 5.3 & 0.4 \\
\hline & $7.6-10.2$ & 5 & 5.9 & 18 & $A B$ & 5.9 & 0.1 \\
\hline & $10.2-12.7$ & 4 & 6.0 & 24 & $A$ & 6.0 & 0.2 \\
\hline & $12.7-15.2$ & 5 & 6.0 & 26 & $A$ & 6.2 & 0.3 \\
\hline \multirow[t]{6}{*}{ R-44 } & $0-2.5$ & 5 & 6.1 & 11 & $A$ & 6.0 & 0.2 \\
\hline & $2.5-5.1$ & 5 & 6.0 & 9.4 & $A$ & 6.0 & 0.1 \\
\hline & $5.1-7.6$ & 5 & 6.0 & 13 & $A$ & 6.1 & 0.2 \\
\hline & $7.6-10.2$ & 5 & 6.0 & 16 & $A$ & 6.2 & 0.2 \\
\hline & $10.2-12.7$ & 5 & 6.2 & 20 & $A$ & 6.3 & 0.1 \\
\hline & $12.7-15.2$ & 5 & 6.4 & 24 & $A$ & 6.3 & 0.1 \\
\hline
\end{tabular}

\begin{tabular}{l}
\hline $\begin{array}{l}\text { Table A11 } \\
\text { Mineralogy of Six Depth Sections from Composite Cores from HAAF (SM-1) }\end{array}$ \\
\hline \hline \multirow{2}{*}{ Mineralogy parameter (Weight Percent) } \\
\cline { 2 - 7 }
\end{tabular}




\begin{tabular}{|l}
\hline $\begin{array}{l}\text { Table A12 } \\
\text { Mineralogy of Six Depth Sections from Composite Cores from HAAF (SM-10) }\end{array}$ \\
\hline \hline \multirow{2}{*}{ Mineralogy parameter (Weight\%) } \\
\cline { 2 - 7 }
\end{tabular}

\section{Table A13}

Mineralogy of Six Depth Sections from Composite Core Samples from China Camp $(\mathbf{R}-44)^{1}$

\begin{tabular}{|c|c|c|c|c|c|c|}
\hline \multirow{2}{*}{ Mineralogy parameter (Weight \%) } & \multicolumn{6}{|c|}{ Depth, cm } \\
\hline & $0-2.5$ & $2.5-5.1$ & $5.1-7.6$ & $7.6-10.2$ & $10.2-12.7$ & $12.7-15.2$ \\
\hline \multicolumn{7}{|l|}{ Whole Rock Mineralogy } \\
\hline Quartz & $23.5 \%$ & $25.7 \%$ & $24.8 \%$ & $24.6 \%$ & $24.6 \%$ & $22.5 \%$ \\
\hline K-Feldspar & $2.3 \%$ & $2.0 \%$ & $2.4 \%$ & $2.2 \%$ & $2.0 \%$ & $1.6 \%$ \\
\hline Plagioclase & $25.7 \%$ & $28.2 \%$ & $27.4 \%$ & $27.3 \%$ & $25.5 \%$ & $23.4 \%$ \\
\hline Amphibole & $4.0 \%$ & $1.5 \%$ & $5.0 \%$ & $3.0 \%$ & $1.8 \%$ & $2.6 \%$ \\
\hline Pyrite & $0.9 \%$ & $0.0 \%$ & $4.0 \%$ & $5.2 \%$ & $8.3 \%$ & $8.1 \%$ \\
\hline Natrojarosite & $0.0 \%$ & $0.0 \%$ & $0.0 \%$ & $1.6 \%$ & $2.0 \%$ & $1.5 \%$ \\
\hline Gypsum & $2.9 \%$ & $1.5 \%$ & $1.9 \%$ & $1.6 \%$ & $1.6 \%$ & $1.3 \%$ \\
\hline Halite & $2.0 \%$ & $0.9 \%$ & $1.2 \%$ & $1.0 \%$ & $0.8 \%$ & $1.2 \%$ \\
\hline \multicolumn{7}{|l|}{ Phyllosilicate Mineralogy } \\
\hline $\mathrm{R}=0 \mathrm{M}-\mathrm{L} \mathrm{I} / \mathrm{S}(90 \% \mathrm{~S})^{2}$ & $11.9 \%$ & $14.0 \%$ & $10.7 \%$ & $10.8 \%$ & $10.2 \%$ & $11.2 \%$ \\
\hline Illite \& Mica & $13.0 \%$ & $12.1 \%$ & $10.5 \%$ & $10.7 \%$ & $10.8 \%$ & $13.9 \%$ \\
\hline Kaolinite & $4.1 \%$ & $4.4 \%$ & $3.3 \%$ & $4.5 \%$ & $4.4 \%$ & $4.8 \%$ \\
\hline Chlorite & $9.8 \%$ & $9.7 \%$ & $8.8 \%$ & $7.4 \%$ & $7.8 \%$ & $7.9 \%$ \\
\hline
\end{tabular}




\begin{tabular}{|l|l||}
\hline $\begin{array}{l}\text { Table A14 } \\
\text { Mineralogy of Six Depth Sections from Core Samples from Bel Marin (BM-50a) }\end{array}$ \\
\hline \hline \multirow{2}{*}{$\begin{array}{l}\mathbf{1} \\
\text { Mineralogy parameter (Weight Percent) }\end{array}$} \\
\cline { 2 - 7 }
\end{tabular}

\begin{tabular}{|c|c|c|c|c|c|c|c|}
\hline \multicolumn{8}{|c|}{$\begin{array}{l}\text { Table A15 } \\
\text { Mineralogy of Seven Depth Sections from Cores from Hamilton Upland Site }(\mathrm{SM}-10 \mathrm{U})^{1}\end{array}$} \\
\hline \multirow[b]{2}{*}{ Mineralogy parameter (Weight Percent) } & \multicolumn{7}{|c|}{ Depth (cm) } \\
\hline & $0-7.6$ & $7.6-10.2$ & $10.2-14.0$ & $14.0-17.8$ & $17.8-24.1$ & $24.1-30.5$ & $30.5-40.6$ \\
\hline \multicolumn{8}{|l|}{ Whole Rock Mineralogy } \\
\hline Quartz & $30.3 \%$ & $29.9 \%$ & $26.8 \%$ & $25.2 \%$ & $25.5 \%$ & $24.7 \%$ & $26.6 \%$ \\
\hline K-Feldspar & $3.6 \%$ & $1.7 \%$ & $2.1 \%$ & $1.8 \%$ & $1.3 \%$ & $1.7 \%$ & $2.0 \%$ \\
\hline Plagioclase & $22.3 \%$ & $19.3 \%$ & $20.7 \%$ & $23.6 \%$ & $25.4 \%$ & $20.5 \%$ & $19.3 \%$ \\
\hline Amphibole & $0.0 \%$ & $2.3 \%$ & $0.0 \%$ & $0.0 \%$ & $2.4 \%$ & $2.6 \%$ & $2.6 \%$ \\
\hline Pyrite & $1.3 \%$ & $1.0 \%$ & $0.7 \%$ & $0.6 \%$ & $0.9 \%$ & $1.3 \%$ & $1.3 \%$ \\
\hline Natrojarosite & $0.0 \%$ & $0.0 \%$ & $0.0 \%$ & $0.0 \%$ & $0.0 \%$ & $0.0 \%$ & $0.0 \%$ \\
\hline Gypsum & $0.0 \%$ & $0.0 \%$ & $0.0 \%$ & $0.0 \%$ & $0.0 \%$ & $0.0 \%$ & $0.0 \%$ \\
\hline Halite & $6.7 \%$ & $2.6 \%$ & $2.1 \%$ & $2.6 \%$ & $2.9 \%$ & $2.2 \%$ & $3.1 \%$ \\
\hline \multicolumn{8}{|l|}{ Phyllosilicate Mineralogy } \\
\hline $\mathrm{R}=0 \mathrm{M}-\mathrm{L} \mathrm{I} / \mathrm{S}(90 \text { percentS })^{2}$ & $12.6 \%$ & $12.8 \%$ & $16.6 \%$ & $15.2 \%$ & $11.0 \%$ & $15.1 \%$ & $12.9 \%$ \\
\hline Illite \& Mica & $10.2 \%$ & $15.3 \%$ & $14.1 \%$ & $14.8 \%$ & $14.4 \%$ & $14.7 \%$ & $13.8 \%$ \\
\hline Kaolinite & $4.4 \%$ & $6.3 \%$ & $6.5 \%$ & $7.7 \%$ & $6.9 \%$ & $8.0 \%$ & $8.4 \%$ \\
\hline Chlorite & $8.6 \%$ & $8.8 \%$ & $10.4 \%$ & $8.5 \%$ & $9.3 \%$ & $9.3 \%$ & $10.0 \%$ \\
\hline
\end{tabular}




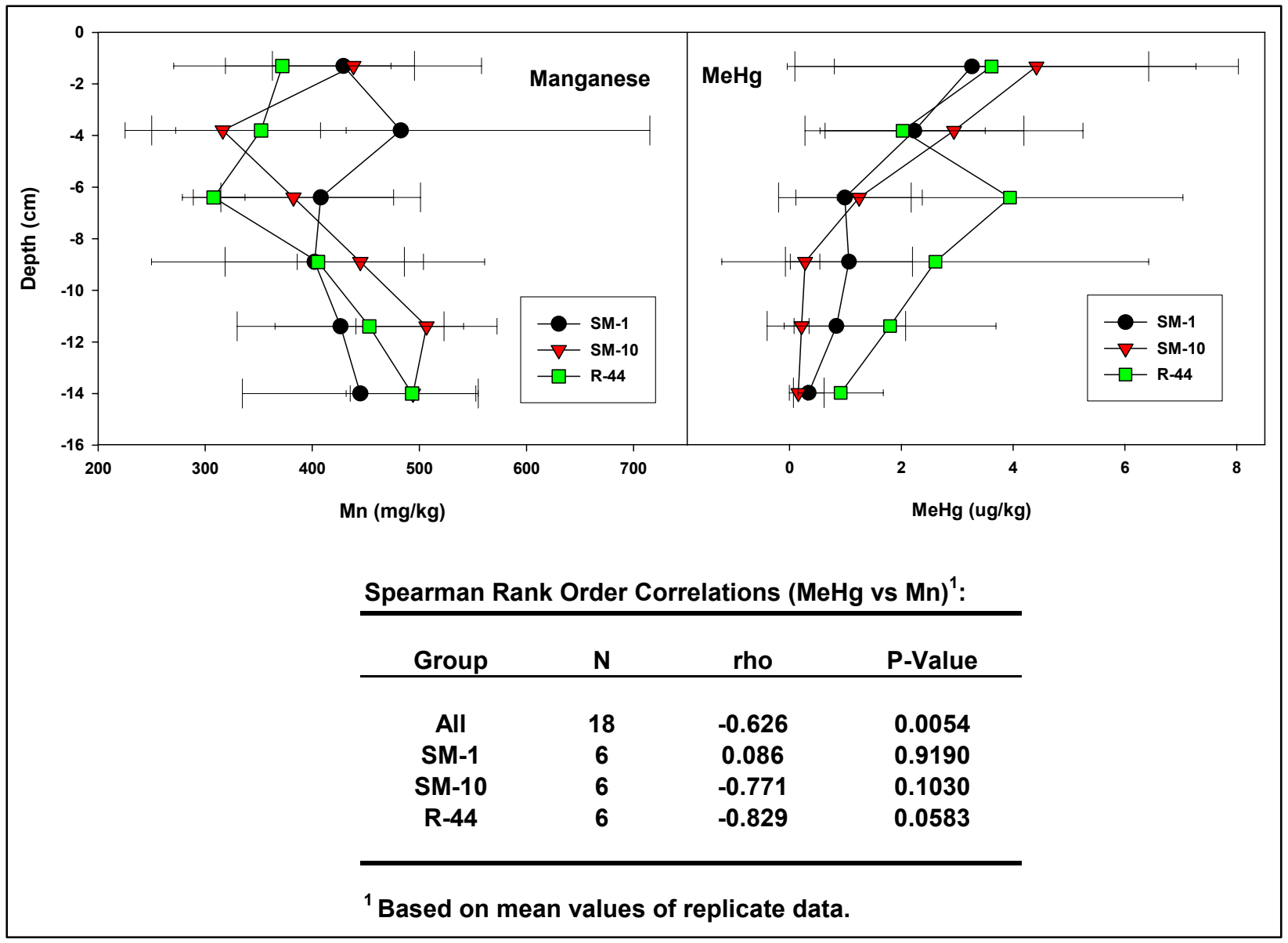

Figure A1. Depth profile comparisons and correlations for manganese $(\mathrm{Mn})$ and methylmercury $(\mathrm{MeHg})$ from replicate core samples collected at HAAF (SM-1 \& SM-10) and China Camp (R-44). Symbols represent mean of replicate data $(n=5)$; error bars indicate standard deviation 


\section{Appendix B}

\section{Addendum to Chapter 7, QnD:HAAF Model Design - Technical Description, Equations, and Calibration}

\section{Overview of the QnD Model System}

The Questions and Decisions ${ }^{\mathrm{TM}}(\mathrm{QnD})$ screening model system was created to provide an effective tool to incorporate ecosystem, management, economics, and socio-political issues into a user-friendly model framework. The model is written in object-oriented Java and can be deployed as a stand-alone program or as a web-based (browser-accessed) "applet." The QnD model links the spatial components within geographic information system (GIS) files to the abiotic, climatic, and biotic interactions that exist in an ecosystem.

The model can be constructed using any combination of measured data or estimated interactions of the ecological, management, social, and/or economic forces influencing an ecosystem. The model development is iterative and can be initiated quickly through conversations with users or stakeholders. Model alterations and/or more detailed processes can be added throughout the model development process.

The configuration of QnD is meant to be iterative to enable the exploration of concepts of interest and the subsequent expansion or disposal as further learning occurs. The major inputs of QnD:HAAF include the following (Figure B1):

a. Four spatial areas (land areas, river reaches, wetlands), interconnected or individual ("stand-alone" mode)

b. Habitats, i.e., forest, grassland, and bare patches within the Spatial Areas

c. Environmental drivers (rainfall, temperature, tidal activity) and time scales (hours, days, months, quarters, years)

d. Chemicals (total mercury, methylmercury) 
e. Biota (microbes, plants, invertebrate and vertebrate animals)

f. Estimated relationships between chemicals, biota, and drivers.

The next section describes these QnD model components in more detail for the HAAF wetland ecosystem.

\section{QnD:HAAF Model Description}

The various objects used in the initial version of QnD:HAAF are presented in Figure B1. These objects (chemicals, organisms and drivers) exist within a "virtual" landscape of spatial areas and habitats. The chemical and organism objects participate in specific processes that cause changes in the ecosystem. For example: within a High Marsh (spatial area object), a crab (organism object) may take up $\mathrm{MeHg}$ from the sediment (chemical object). A more complete description of the spatial areas, habitats, chemicals and organism objects and their associated processes is given in further detail in the sections below.

\section{Spatial areas}

Whereas QnD can simulate ecosystem components and processes for an entire map of linked spatial areas, the initial version of QnD:HAAF utilizes four stylized wetland areas (Figure B2). This spatial simplification allows the use of the data of initial feasibility studies with simplified modeling concepts, instead of attempting to fit a complex model to an ecosystem in which little data have been collected. In QnD:HAAF, the selected scale of each spatial area is $10 \mathrm{~m} \times 10 \mathrm{~m}$ $\left(100 \mathrm{~m}^{2}\right)$, all mass data are on a dry weight basis, and all simulated data are on a square meter basis.

The "High Marsh" area represents Salicornia virginica (pickle weed)-dominated areas that are rarely flooded. The "Mid Marsh" area represents Spartina foliosa (cord grass)-dominated areas that are partially flooded as a part of the daily tidal cycle. The third spatial area represents the "Mud Flat" zone that is partially submerged. The fourth spatial area represents the "Sub Tidal" zone that is completely submerged. The elevation of each spatial area is kept constant. High Marsh was kept at 3.0 feet $(1 \mathrm{~m})$ above Mean High Water (MHW), Mid Marsh at 1.0 foot $(0.333 \mathrm{~m})$, Mud Flat at 0.5 foot $(0.167 \mathrm{~m})$ and Sub Tidal at $-1.0 \mathrm{ft}(-0.333 \mathrm{~m})$. Each spatial area has resident biota listed in Figure B2. Upgrades of QnD:HAAF will expand these elementary spatial areas into linked maps of wetlands that can be managed separately or in groups for ecosystem/management objectives.

\section{Habitats}

Habitats exist within and occupy a fraction of each spatial area. The habitats are assumed to be homogeneous and harbor different combinations of biota and chemicals. In the initial version of QnD:HAAF, no specialized habitats within the spatial areas are distinguished, i.e. one "default" habitat occupies 100 percent of 
the spatial area . In later model versions, a plant- and a non-plant influenced habitat within each spatial area may be introduced. This modification would allow QnD to simulate the effects of depositing dredged material on a vegetated area. This management action may convert a portion of a vegetated wetland temporarily into a mud flat with altered $\mathrm{Hg}$ dynamics.

\section{Environmental drivers and time scales}

Three environmental drivers were selected to link processes at time scales varying from current (on site measured methylation and demethylation rates in light versus in darkness, Chapter 3 of this report) to seasonal (wet versus dry season data on $\mathrm{THg}$ and $\mathrm{MeHg}$ concentrations in the sediment, cf. McFarland et al. 2003a,b). An on-line tide simulator for the Bay area was used to provide initial estimates of tidal water levels for selected time periods on an hourly basis (http://tbone.biol.sc.edu/tide/sitesel.html). Values pertaining to the mouth of the Petaluma River were selected, since these were considered as representative for the nearby HAAF. In general, SI units are used. The only exception is water depth, where feet are used for easy import of water-level data from the on-line tide simulator.

For initial QnD:HAAF v1.0 testing, two hourly time series were constructed, representing a dry season, i.e., 1-14 June 2003, and a wet season, i.e., 1-14 February 2004), respectively. QnD:HAAF v1.0 utilizes a default time step of $1 \mathrm{hr}$, can model results and, thus, easily be converted into daily values by multiplication with a factor of 24 .

Tidal and Redox Processes. Water depth on each spatial area is calculated by subtracting its local elevation hourly from tidal water level, using the following equation (B1):

$$
\text { WaterDepth }=\text { TidalDepth }- \text { Elev }_{\text {base }}
$$

where

$$
\begin{aligned}
\text { WaterDepth } & =\text { local water depth on the spatial area }(\mathrm{ft}) \\
\text { TidalDepth } & =\text { hourly tidal depth }(\mathrm{ft}) \\
\text { Elev }_{\text {base }} & =\text { base elevation of the surficial sediment layer }(\mathrm{ft})
\end{aligned}
$$

If the calculated local water depth (WaterDepth) has a positive sign, then the spatial area is considered as being submerged and susceptible to decreasing oxygen diffusion. Vice versa, if the calculated local water depth has a negative sign, then the spatial area is considered as extending above the water level and thus susceptible to oxygen diffusion from the ambient air.

WaterDepth is used subsequently to calculate the number of hours in which the spatial area is submerged or extended above the water level, which, in turn, governs changes in redox potential. The simplified relationship between water depth and change in number of hours under water is presented in Figure B3. 
Subsequently, the cumulative numbers of hours under and above the water level, respectively, are used to calculate the hourly change in redox potential $(\mathrm{mV}$; Figure B4). The maximum and minimum values of the hourly change in redox potential do not change as they represent the stable redox potential values of areas that are, respectively, above and below the water level for longer periods (for example, the High Marsh or SubTidal spatial zones). The hourly change in redox potential is then added to the cumulative redox potential for each spatial zone. The fluctuations in redox potential in all spatial areas were delimited by an assigned upper boundary of $300 \mathrm{mV}$ and a lower boundary of $-300 \mathrm{mV}$. These initial redox relationships were estimated from redox dynamics reported in Bartlett and Craig (1981a,b) and should be further validated through site measurements.

\section{Hg dynamics}

Two chemical Hg pools are assumed to exist and available for transformation: $\mathrm{THg}$ and $\mathrm{MeHg}$ (Figure B1). Both pools are assumed to reside in the surficial 5-cm sediment layer and its associated pore water. The pools change in mass per unit area $\left(\mathrm{ng} \mathrm{m}^{-2}\right)$, but have an associated, calculated, concentration (ng $\mathrm{g}^{-1}$ ). The pools are considered as fully active, i.e., the whole THg pool is available for conversion into the $\mathrm{MeHg}$ pool, and vice versa. $\mathrm{THg}$ is transformed into $\mathrm{MeHg}$ as a function of time of year (dry or wet season), redox potential (dependent on tidal movements) and time of day (light or dark conditions). The values assigned to the pools of $\mathrm{Hg}$ are defined by the analytical procedures used to measure $\mathrm{THg}$ and $\mathrm{MeHg}$. It is assumed that all $\mathrm{THg}$ and $\mathrm{MeHg}$ are reactive, but this may be an overestimate since only a fraction may be reactive and/or is bioavailable. However, it is currently not known what and how large the reactive and bioavailable fractions are.

The inputs of the THg and MeHg pools originate from the TotalLoad pools (objects) that contain the chemical mass values $\left(\mathrm{ng} \mathrm{m}^{-2}\right)$ and are calculated using equation (B2):

$$
\text { Load }=\text { Conc } \times \text { Depth } \times \text { BD } \times 10,000
$$

where

$$
\begin{aligned}
\text { Load } & =\text { the total mass }\left(\mathrm{ng} \mathrm{m} \mathrm{m}^{-2}\right) \text { of } \mathrm{Hg}^{2+} \text { or } \mathrm{MeHg} \\
\mathrm{Conc} & =\mathrm{Hg}^{2+} \text { or meHg concentration }\left(\mathrm{ng} \mathrm{g}^{-1} \mathrm{DW}\right) \\
\text { Depth } & =\text { depth }(\mathrm{cm}) \text { sediment, assumed to be } 5 \mathrm{~cm} \\
\mathrm{BD} & =\text { bulk density sediment on a dry weight basis } \\
10,000 & =\text { conversion from } \mathrm{cm}^{2} \text { to } \mathrm{m}^{2}
\end{aligned}
$$

Bulk density was derived as follows. A bulk density on basis of $1.29 \mathrm{~g} \mathrm{WW}$ $\mathrm{cm}^{-3}$ was measured by M. Marvin-DiPasquale, USGS Menlo park, CA (unpublished results, 2004). The latter value was converted to BD on a dry weight basis, 
assuming that $1 \mathrm{~g}$ wet sediment represents $0.438 \mathrm{~g}$ DW (Table 3-5). The calculated BD was $0.565 \mathrm{~g} \mathrm{DW} \mathrm{cm}^{-3}$.

The initial concentrations and calculated loads of $\mathrm{THg}$ and $\mathrm{MeHg}$ are presented in Table B1. Initial concentrations have been derived from data collected at HAAF in 2003 (Chapter 3 of this report). All Hg-related calculations are carried out in nanograms on a dry weight basis, and subsequently the nanograms are converted into concentrations.

Hg Methylation. The methylation process is presented in Figure B5. In the model, methylation is affected by redox potential, tidal water movements, season, and light/dark conditions. The calculations of water depth and redox potential, prerequisites for the calculation of methylation, have been described in the previous section.

The base $\mathrm{THg}$ methylation rates have been derived from the rates measured in the field in 2003, under dry season, daylight, and oxic conditions (Table B2).

In the model, the amount of $\mathrm{Hg}$ methylated hourly in each spatial area is calculated as a percentage of the total available, inorganic $\mathrm{Hg}^{2+}$ pool (TotalHg), and follows equation (B3):

$$
\operatorname{MeHg}_{n}=\left(\begin{array}{c}
\text { BaseRate }_{\text {meth }} \times \text { Season }(\text { month }) \times \operatorname{Re} \text { dox }_{m}(\text { hours }) \\
\times \text { Light }_{m}(\text { daylight }) \times \operatorname{TotalHg}(3)
\end{array}\right)
$$

where

BaseRate $_{\text {meth }}=\mathrm{THg}$ methylation (ng MeHg methylated $\mathrm{ng}^{-1} \mathrm{Hg}^{2+} \mathrm{hr}^{-1}$ )

Season $($ month $)=$ seasonal, month-specific, effect on methylation rate (-)

$\operatorname{Redox}_{\mathrm{m}}($ hours $)=$ redox potential effect on methylation rate, depending on the cumulative number of hours under water or extending above the water level (-)

$\operatorname{Light}_{\mathrm{m}}($ daylight $)=$ daylight effect on methylation rate depending on time of day $(-)$

$$
\text { TotalHg }=\text { size } \mathrm{Hg}^{2+} \text { pool (ng DW) }
$$

$\mathrm{MeHg}$ concentrations in the sediments were found to be higher in the wet season than in the dry season by McFarland et al. (2003a,b). It is not clear if these differences were caused by higher methylation or lower demethylation rates, or both. Nevertheless, to enable the calculation of methylation rates accounting for effects of dry and wet season on methylation rates, multiplication factors relating wet season activity to dry season activity were derived from mean dry season and mean wet season $\mathrm{MeHg}$ concentrations in the sediment as ratios (McFarland et al. 2003a,b, Table B2). The seasonal factors for the spatial areas are listed in Table B3. Since base methylation rates were measured in the dry season of 2003, the multiplication factors for the dry season are 1.0. The multiplication factors accounting for the effects of a wet season range from 1.6 in 
the Mud Flat and Sub Tidal spatial areas to 8.8 in the High and Mid Marsh spatial areas vegetated by Salicornia and Spartina, respectively. The dry season in the model lasts from April through October, and the wet season from November through March.

Methylation rates were found to be generally 40 to 50 percent lower in darkness than in light (Chapter 3 of this report). In QnD:HAAF, factors accounting for the decreasing effect of darkness have been derived from the field data. These factors are listed in Table B4. Night time in the model lasts from 6 PM to 6 AM.

The relative effect of redox potential on the methylation of $\mathrm{Hg}$ follows a stylized Gauss curve with a maximum of 1 at a redox potential between -100 and $+100 \mathrm{mV}$, and minima of 0.1 at redox potential values more negative than $-300 \mathrm{mV}$ and more positive than $300 \mathrm{mV}$ (Figure B6). This curve has been fitted to data of Bartlett and Craig (1981a,b), and modified by McFarland and Lee (2002). Methylation proceeds at the highest rate between -100 and $100 \mathrm{mV}$ potential.

MeHg Demethylation. The demethylation process is represented in Figure $\mathrm{B} 7 . \mathrm{MeHg}$ is demethylated and returns as $\mathrm{Hg}$ to the active $\mathrm{Hg}^{2+}$ pool following a simplified, first-order, rate equation (DTMC/SRWP 2002), which is affected by redox potential, tidal water movements, season, and light/dark conditions.

The base $\mathrm{MeHg}$ demethylation rates have been derived from the rates measured in the field in 2003, under dry season, daylight, and aerobic conditions (Table B5).

In the model, the amount of $\mathrm{MeHg}$ demethylated hourly in each spatial area is calculated as a percentage of the $\mathrm{MeHg}$ pool, and follows equation (B4):

demethHg $_{t}=$ BaseRate $_{\text {Demeth }} \times \operatorname{Re}$ dox $_{d}($ hours $) \times$ Light $_{d}\left({\text { daylight }) \times m e H g_{t}}\right.$

where

$$
\begin{aligned}
\text { BaseRate }_{\text {demeth }}= & \text { MeHg demethylation rate (ng MeHg demethylated } \mathrm{ng}^{-1} \mathrm{MeHg} \\
& \left.\mathrm{hr}^{-1}\right) \\
\text { Redox }_{\mathrm{d}} \text { (hours) }= & \text { redox potential effect on demethylation rate depending on the } \\
& \begin{array}{l}
\text { cumulative number of hours under water or extending above } \\
\text { the water level (-) }
\end{array}
\end{aligned}
$$

$\operatorname{Light}_{\mathrm{d}}($ daylight $)=$ daylight effect on demethylation rate depending on time of day (-)

$$
\mathrm{MeHg}=\text { size } \mathrm{MeHg} \text { pool (ng DW) }
$$

Demethylation rates were found to be generally 25 percent lower in darkness than in light, except in the Spartina-vegetated Mid Marsh where it was elevated by almost 50 percent (Chapter 3 of this report). In QnD:HAAF, factors accounting for the effect of darkness have been derived from the field data. These factors are listed in Table B6. 
The relative effect of redox potential on demethylation of $\mathrm{MeHg}$ follows a linearized saturation curve with a maximum of 1 at a redox potential more positive than $100 \mathrm{mV}$, and a minimum of 0.1 at a redox potential more negative than $-100 \mathrm{mV}$ (Figure B8). This curve has been fitted to data of Bartlett and Craig (1981a,b), modified by McFarland and Lee (2002), and data of Chapter 3 in this report.

Simple MeHg Export From Sediments. In QnD:HAAF, $\mathrm{MeHg}$ is exported from the sediments at a constant rate as described in Table 3-12. It is assumed that 0.8 percent of the $\mathrm{MeHg}$ in the sediment is exported per day (i.e., 0.0333 percent per hour). This amount of $\mathrm{MeHg}$ enters into a non-returnable pool that estimates the potential $\mathrm{MeHg}$ export to the Bay.

\section{Biota}

Selected organisms are included in the QnD:HAAF model, i.e., plants, invertebrates, and one vertebrate animal (a bird). Two emergent macrophytic plant species and one microalgal group are represented in the current version of QnD:HAAF. Salicornia virginica (pickle weed) and Spartina foliosa (cord grass) are simulated at the simplest level as an established standing crop with constant biomass over the 2-week simulation. Plant $\mathrm{MeHg}$ load (ng) and potential contribution to export were assumed to be the primary data of interest in these simulations. The epipelon (algae living on the sediments) are also potential contributors to the export of $\mathrm{MeHg}$. The values on plant biomass and $\mathrm{THg}$ and $\mathrm{MeHg}$ concentrations used to calibrate the model are reported in Chapter 3 of this report. The following wetland invertebrates are modeled as potentially resident in all four spatial areas, but with population size and biomass being spatial areaspecific: Ribbed Mussel (Geukensia Demissa), Yellow Shore Crab (Hemigrapsus Oregonensis), and the Eastern Mud Snail (Iyanassa obsoleta). These animals have been identified in HAAF field samples (Chapter 3 of this report). For exploring the trophic transfer and bioaugmentation of $\mathrm{MeHg}$ to higher levels in the food chain, the California clapper rail (Rallus longirostris obsoletus) is included as potentially resident in all four spatial areas. For the time being, it is assumed that biota do not migrate between spatial areas.

The initial $\mathrm{MeHg}$ pool $\left(\mathrm{MeHg}_{\mathrm{Load}}\right)$ for each organism is calculated using equation (B5):

$$
\mathrm{MeHg}_{\text {Load }}=\mathrm{Org}_{\text {biom }} \times \text { Conc }_{\text {MeHg }}
$$

where

$$
\begin{aligned}
\operatorname{Org}_{\text {biom }} & =\text { organism biomass }(\mathrm{g} \mathrm{DW}) \\
\mathrm{Conc}_{\mathrm{MeHg}} & =\mathrm{MeHg} \text { concentration }\left(\mathrm{ng} \mathrm{g}^{-1} \mathrm{DW}\right)
\end{aligned}
$$

Population and biomass data of the biota were estimated from literature values, because they had not been collected at HAAF (Table B7). Population densities may vary with spatial area, e.g., ribbed mussels, and in those cases different starting values were used. The initial concentrations and calculated 
loads of $\mathrm{MeHg}$ in the biota are presented in Table B8. Initial concentrations have been derived from data collected at HAAF and China Camp (Chapters 3 and 6 of this report).

Uptake of Biomass. In this QnD:HAAF version the relationships between consumers and their food sources are formulated as a predator-prey relationship (Figure B9). According to this approach, when a mud snail grazes epipelon, the mud snail would be a predator and the epipelon would be a prey. The uptake of prey biomass by the predator is calculated using equation (B6):

$$
\text { Intake }_{\text {pred }}=\text { Biom }_{\text {pred }} \times \text { DemandRate }_{\text {prey }}
$$

where

$$
\begin{aligned}
\text { Intake }_{\text {pred }}= & \text { amount of prey biomass ingested by a specific predator } \\
& (\mathrm{g} \mathrm{DW}) \\
\text { Biom }_{\text {pred }}= & \text { predator biomass }(\mathrm{g} \mathrm{DW}) \\
\text { DemandRate }_{\text {prey }}= & \text { amount of prey required per unit weight of the predator } \\
& \text { (g DW prey per g DW predator) }
\end{aligned}
$$

The biomass of the prey is transferred from the prey pool to the predator pool (Intake ${ }_{\text {pred }}$ ). If the prey pool is smaller than the demand of the predator, all available prey biomass is transferred to the predator. The predators and prey demand rates are listed in Table B9.

Biomass Loss. Long-term changes in biomass due to growth and respiration are not included. The biomass of plants (Salicornia, Spartina and epipelon) and ribbed mussels is assumed to be constant within the 2-week simulation period. However, for animals that consume prey organisms (mud snails, shore crabs and clapper rails) and thus would increase in biomass, a mass-loss rate is introduced that is set equal to the biomass uptake rate to enable the simulation of trophic transfer of $\mathrm{MeHg}$. The mass loss rates are listed in Table B10.

Uptake of MeHg Directly from Sediment. In QnD:HAAF, all biota have uptake and loss processes that allow them to potentially bioaccumulate and release MeHg. This methodology is in accordance with DTMC/SRWP (2002), recommending an initial simplified approach, followed by a detailed bioenergetic approach once $\mathrm{MeHg}$ data become available on higher trophic levels. Data on uptake and bioaccumulation of $\mathrm{MeHg}$ from soil, sediment, and pore water are still extremely scarce in the literature, and they are, therefore, largely estimated from most recent research reported in the Chapters 3, 4, 5, and 6 of this report, and from Mason et al. (1996), Rogers (1994), and Barber (2001).

Uptake of $\mathrm{MeHg}$ from sediment is represented in Figure B10, and calculated using equation (B7):

$$
\text { MeHgIntake }_{\text {sed }}=\text { Biomass } \times \text { Transfer }_{\text {sed }} \times \operatorname{Sat}\left(\mathrm{MeHg}_{\text {conc }}\right)
$$


where

MeHgIntake $_{\text {sed }}=$ uptake of MeHg from sediment (ng)

Biomass $=$ biomass organism $(\mathrm{g} \mathrm{DW})$

Transfer $_{\text {sed }}=$ potential MeHg transfer rate from sediment into organism (ng g ${ }^{-1}$ organism-DW)

$\mathrm{Sat}\left(\mathrm{MeHg}_{\mathrm{conc}}\right)=$ relative function that reduces $\mathrm{MeHg}$ uptake to 0.0 when the species-characteristic initial (equilibrium) $\mathrm{MeHg}$ concentrations (Table B8) are reached

$\mathrm{MeHg}$ will only be taken up from the sediment when the MeHg concentration in the organism is below the concentration measured in the field, since the latter is assumed to be in equilibrium with the environment. One potential $\mathrm{MeHg}$ transfer rate from sediment into organism is used for all organisms, i.e. (0.14042 ng MeHg g $\left.{ }^{-1} \mathrm{DW} \mathrm{hr}^{-1}\right)$. This Transfer ${ }_{\text {sed }}$ value was measured in preliminary uptake experiments with $\mathrm{Hg}^{2+}$ on a Macoma species that filters sediment (Chapter 5 of this report). It is planned to include more species-characteristic uptake/transfer rates when these become available.

Uptake of MeHg from Grazing or Predation by Predator. Uptake of $\mathrm{MeHg}$ by ingestion of biotic food sources is represented in Figure B11, and is calculated using equation (B8). This equation has been formulated after Rogers (1994).

$$
\text { MeHgIntake }_{\text {prey }}=\text { Biomass }_{\text {pred }} \times \text { PreyConsumed } \times \mathrm{MeHg}_{\text {prey }}
$$

where

MeHgIntake $_{\text {prey }}=$ uptake of MeHg from ingesting a prey (ng)

$$
\text { Biomass }_{\text {pred }}=\text { biomass predator }(\mathrm{g} \mathrm{DW})
$$

Prey Consumed $=$ biomass prey consumed $(\mathrm{g}$ prey-DW)

$$
\mathrm{MeHg}_{\text {prey }}=\mathrm{MeHg} \text { concentration prey }\left(\mathrm{ng} \mathrm{g}^{-1}\right. \text { prey-DW) }
$$

MeHg Loss from Biota. All macrophytes lose about 50 percent of their biomass per year (estimate Chapter 3 of this report), and, based on this estimate they would also lose that percentage of the $\mathrm{MeHg}$ contained in the plant biomass. In QnD:HAAF all plants, i.e. macrophytes and epipelon, are modeled as losing 50 percent of the $\mathrm{MeHg}$ contained in their maximum standing crop per year, i.e., $5.7078 \times 10^{-3}$ percent $\mathrm{hr}^{-1}$. All animals, including the ribbed mussels with constant biomass, are assumed to release 10 percent of their resident $\mathrm{MeHg}$ load per day, i.e., 0.4167 percent $\mathrm{hr}^{-1}$. The latter value is based on a study on elimination of $\mathrm{THg}$ and MeHg by the zooplankter Daphnia magna feeding on phytoplankton (Tsui and Wang 2004). This amount of $\mathrm{MeHg}$ released enters into a general pool that quantifies the potential $\mathrm{MeHg}$ export to the bay. 


\section{QnD:HAAF Model Results}

\section{Comparison of simulated and measured methylation rates}

An important means to build confidence in the capabilities of QnD:HAAF to generate results that reflect what is happening in the ecosystems of interest is to compare simulated results with measured values. Here, one such case is demonstrated.

The QnD model was used to simulate methylation and demethylation rates in the Salicornia-vegetated High Marsh spatial area over a 2-week period. The simulated values were compared with values measured in a Salicornia-vegetated High marsh along San Francisco Bay by Marvin-DiPasquale et al. (2003). The simulated methylation and demethylation rates of 8.45 and $7.47 \mathrm{ng} \mathrm{g}^{-1} \mathrm{DW}$ day ${ }^{-1}$, respectively, were in the same range as the rates described by Marvin-DiPasquale et al. (2003). A more detailed analysis and comparison of methylation and demethylation rates used for model calibration and those measured by MarvinDiPasquale et al. (2003) is given in Chapter 3 of this report.

As with any modeling effort, more comparisons of simulated values with measured ones will increase the confidence of a model's performance.

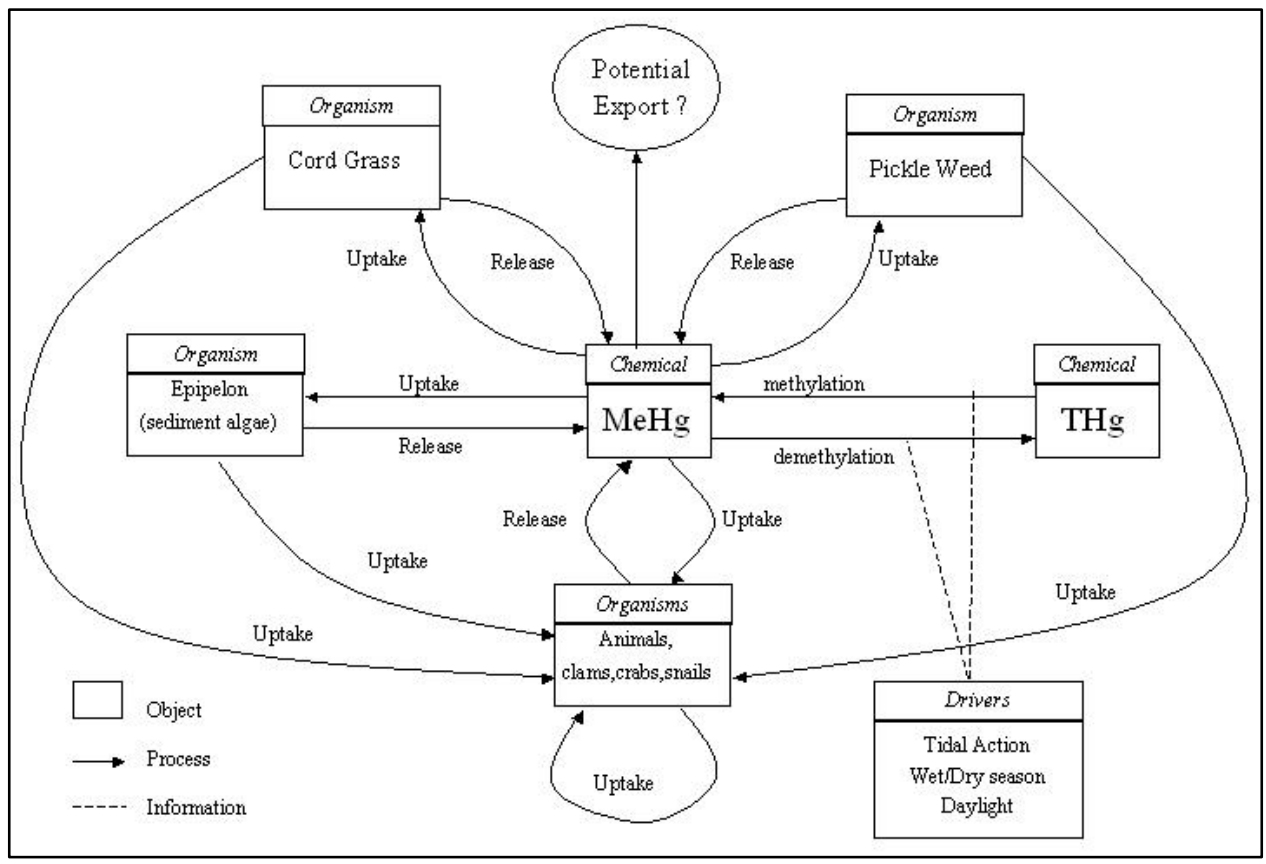

Figure B1. Overview of QnD:HAAF objects, drivers, and processes 


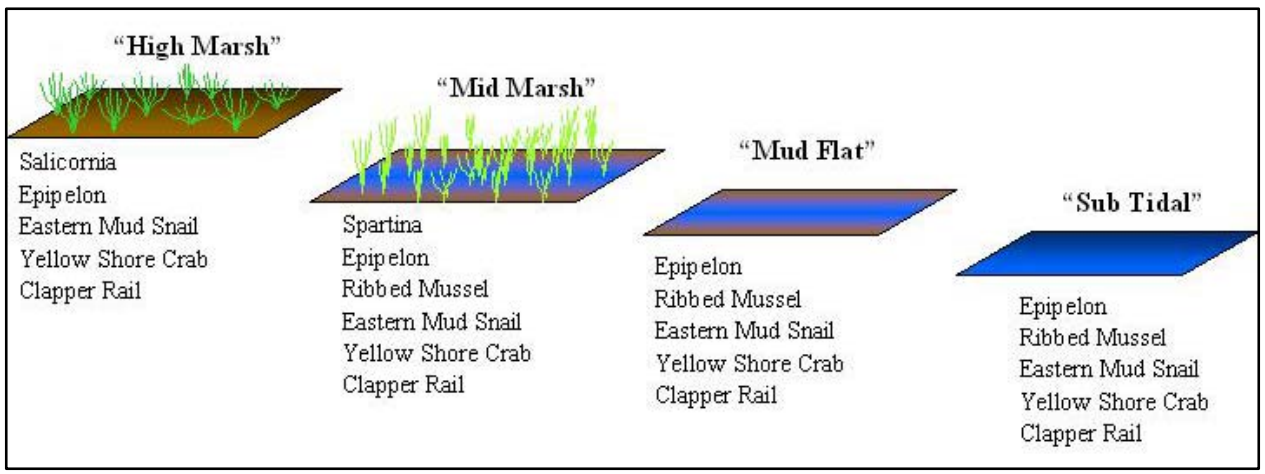

Figure B2. Spatial areas with associated biota within QnD:HAAF version 1.0

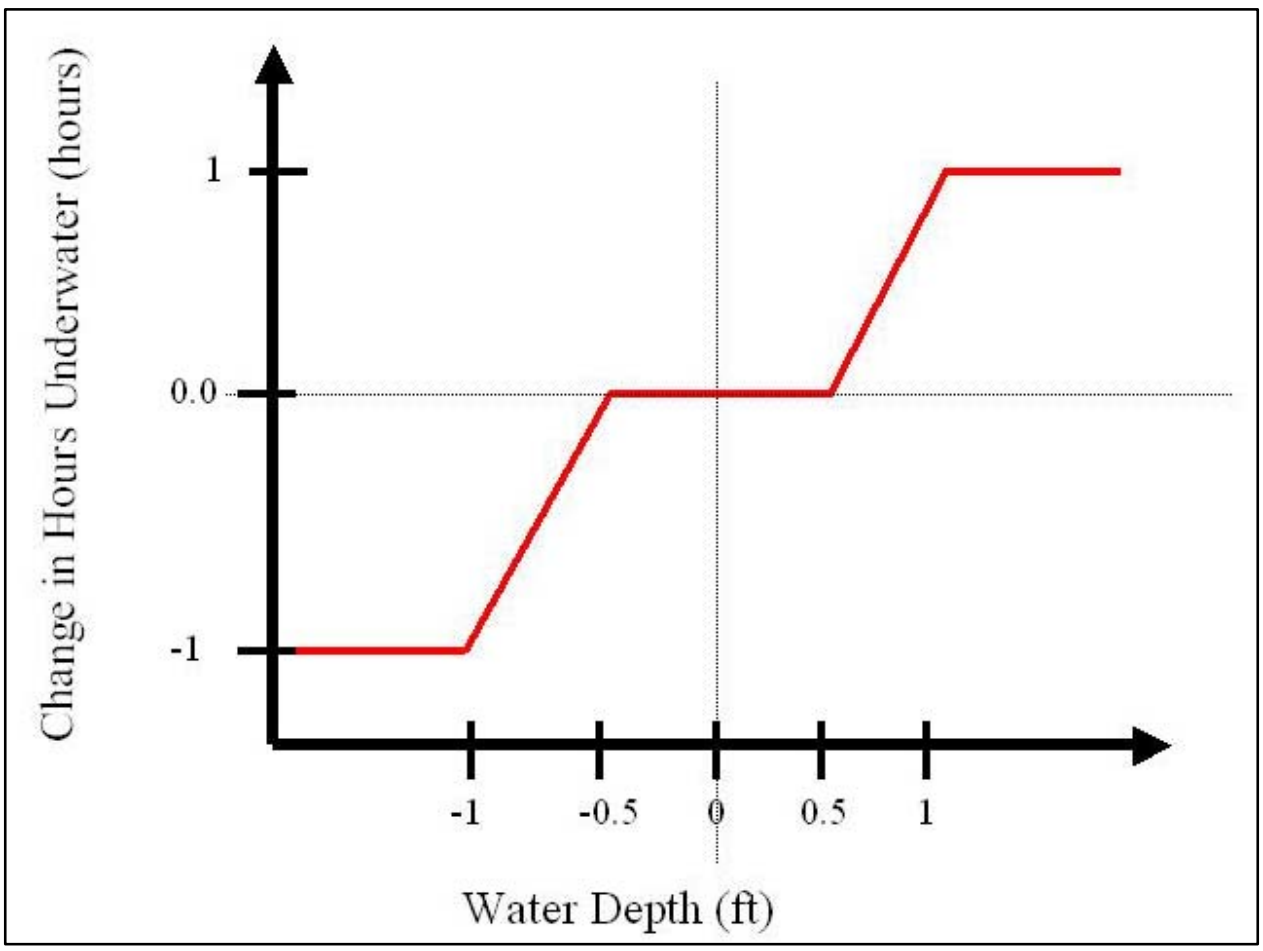

Figure B3. Simplified relationship between local water depth and change in number of hours under water 


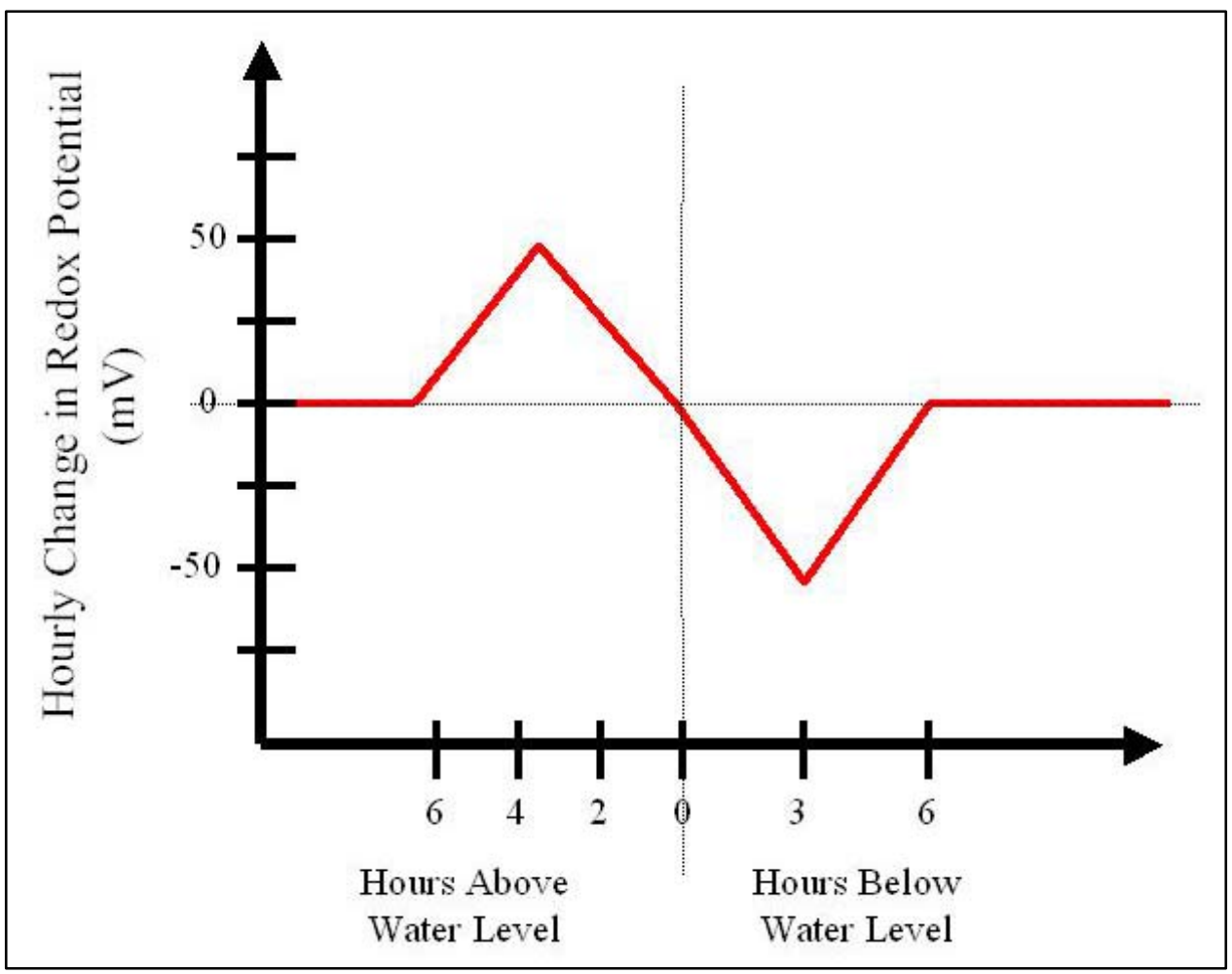

Figure B4. Relationship between hours above and under water, and the hourly change in redox potential

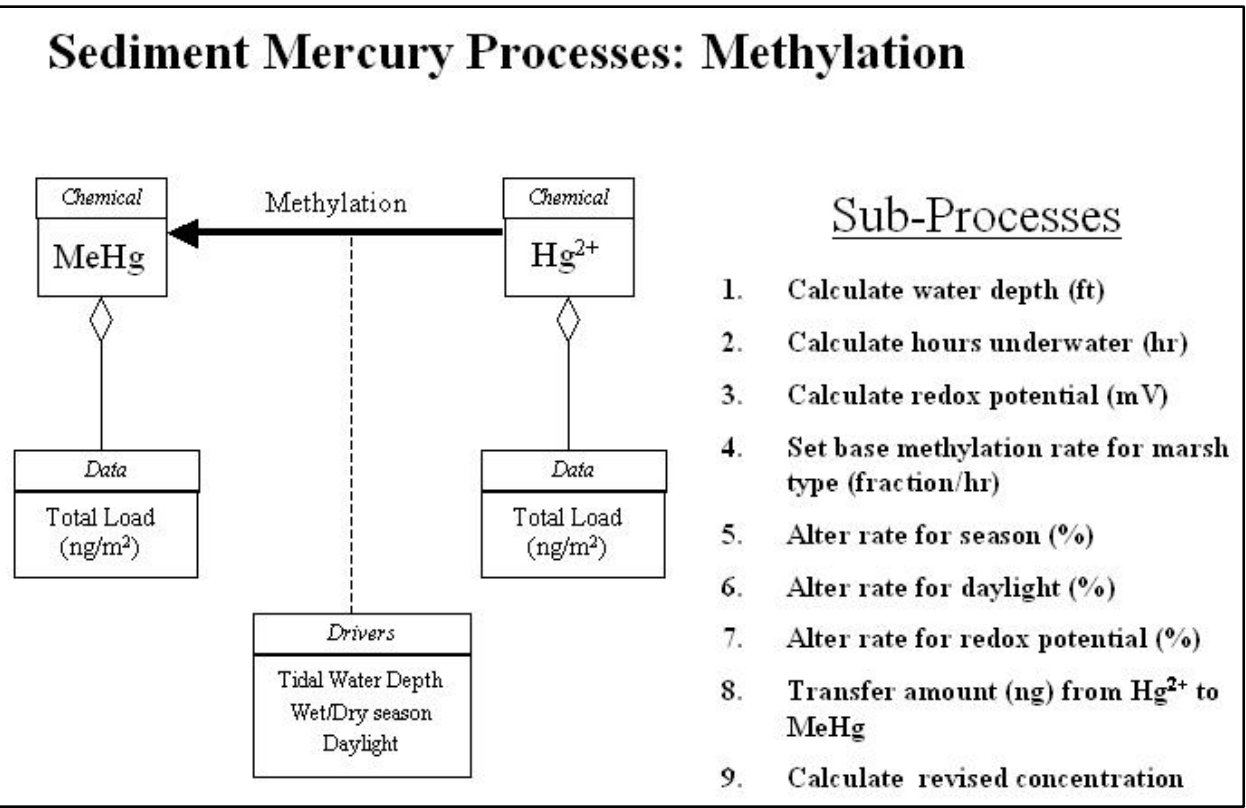

Figure B5. Overview of the QnD:HAAF Hg methylation process 


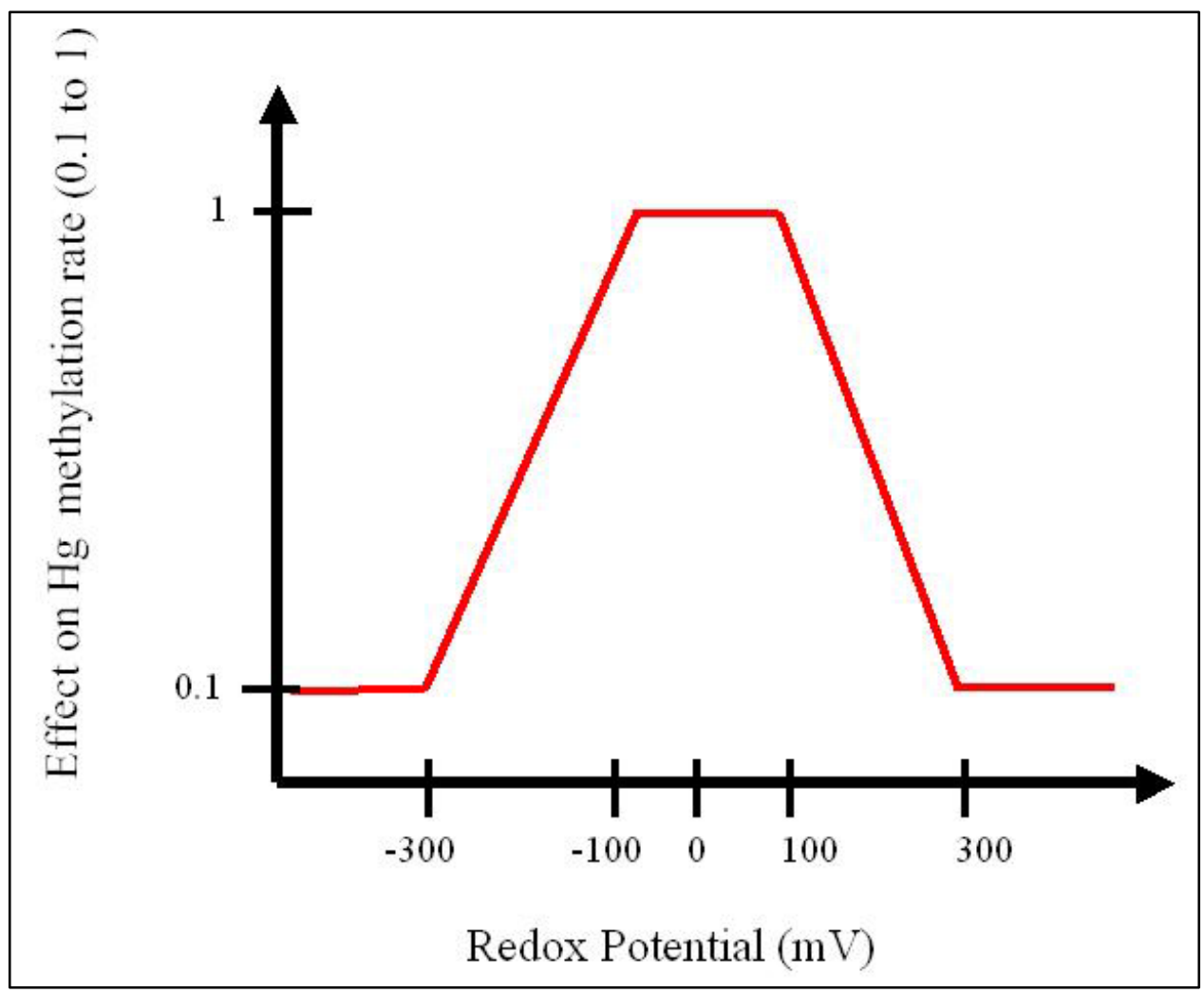

Figure B6. Effect of redox potential on $\mathrm{Hg}$ methylation rate (relative)

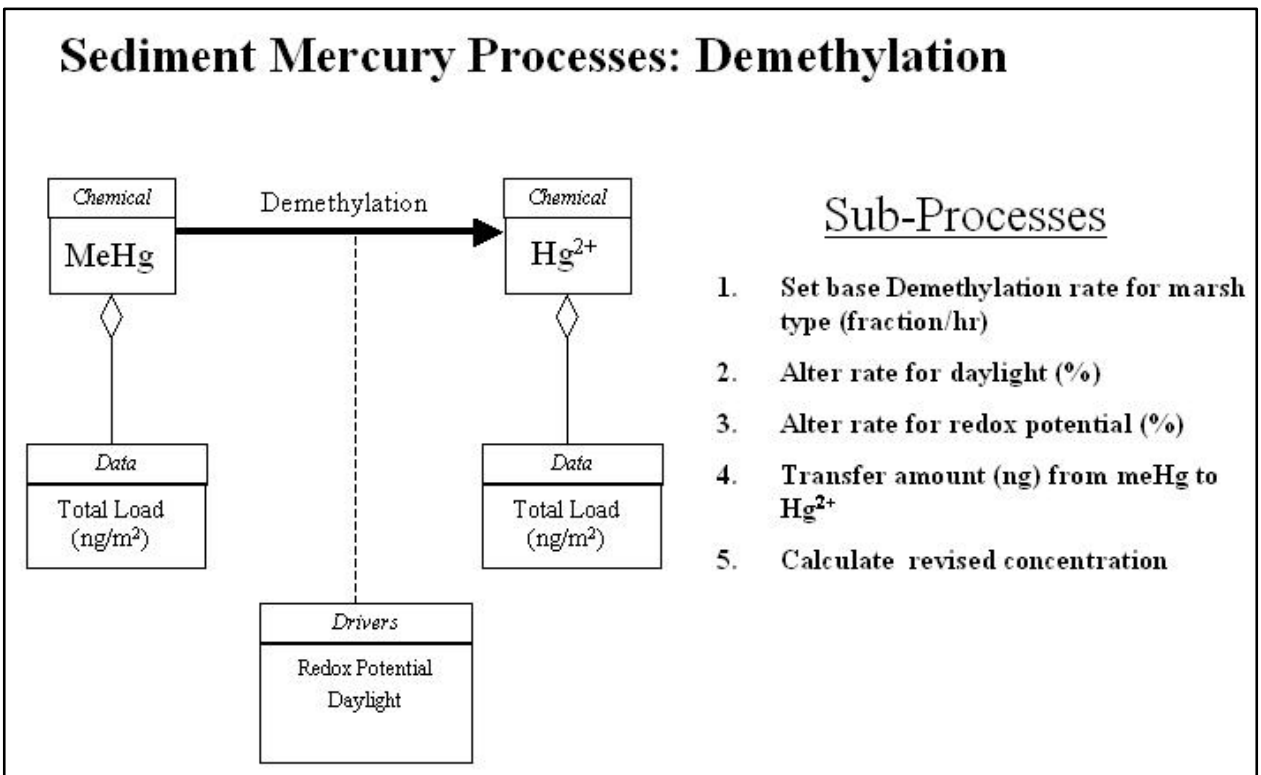

Figure B7. Overview of the QnD:HAAF MeHg demethylation process 


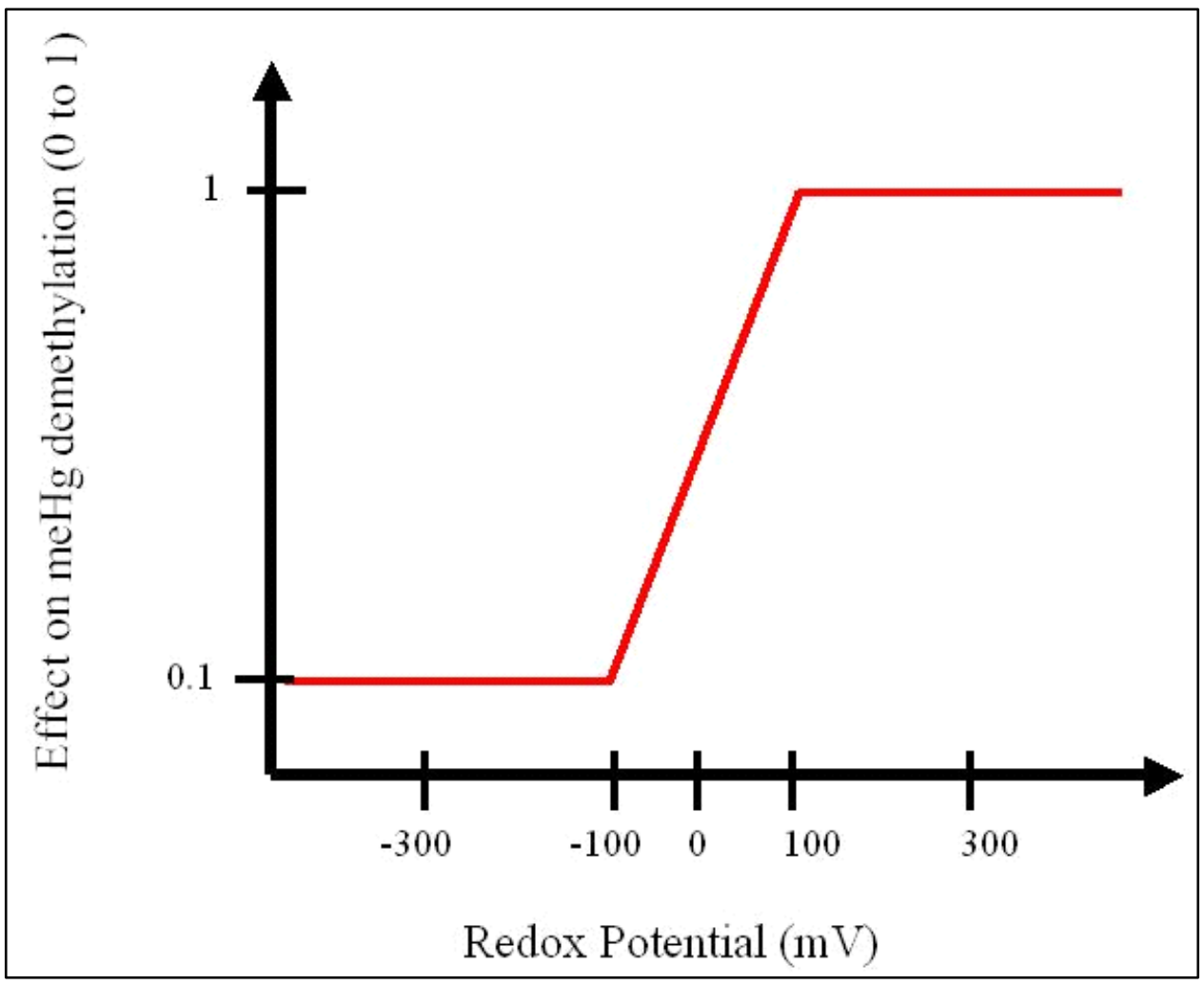

Figure B8. Effect of redox potential on methylmercury demethylation rate (relative)

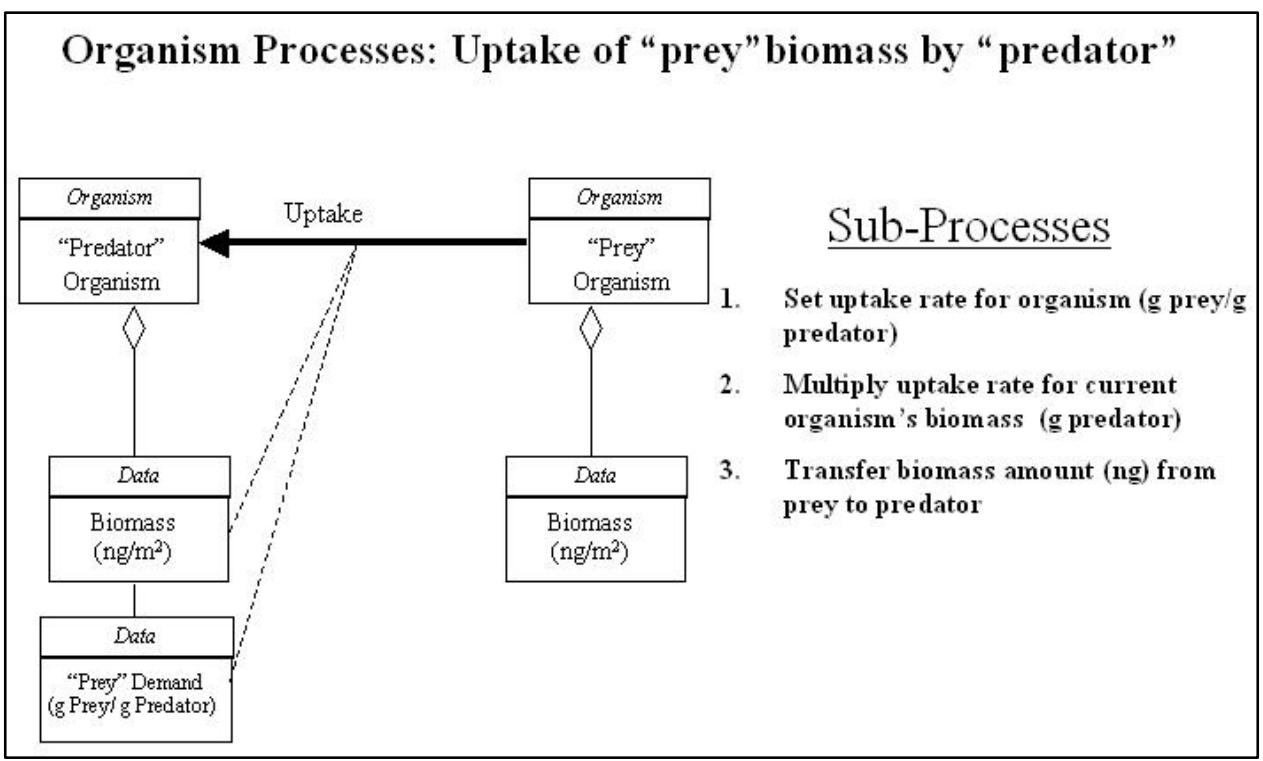

Figure B9. QnD:HAAF uptake of biomass 


\section{Organism Processes: Uptake of MeHg directly from sediment}

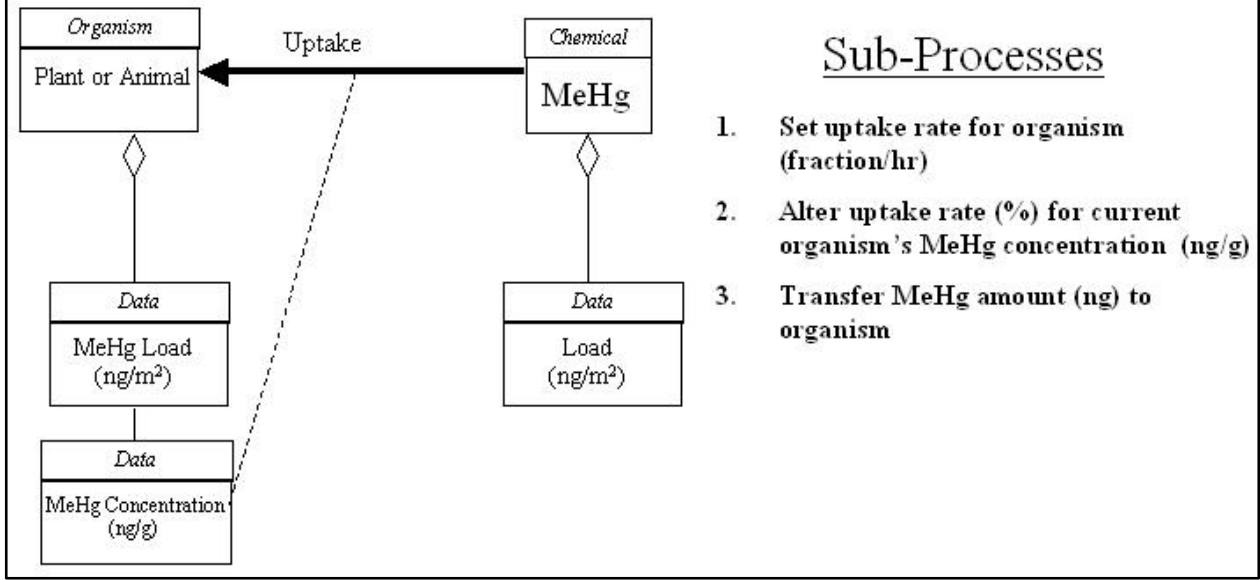

Figure B10. QnD:HAAF uptake of MeHg by organisms directly from sediment

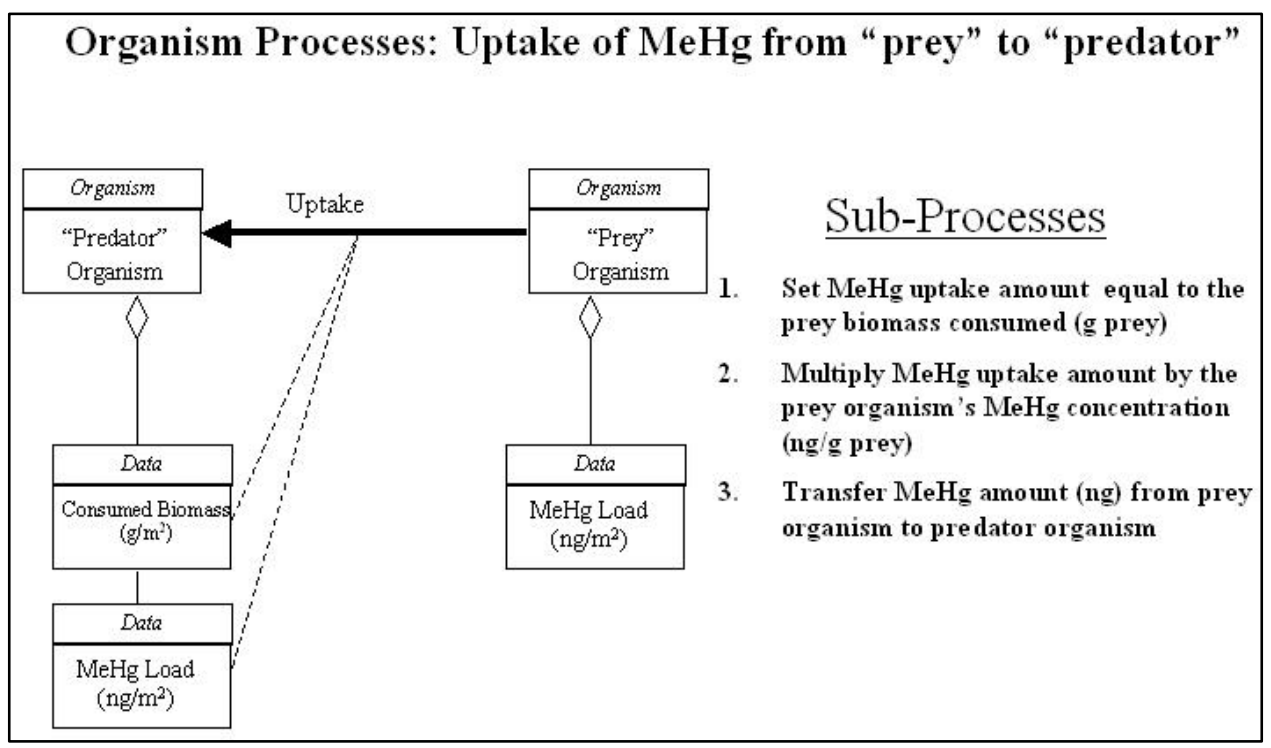

Figure B11. QnD:HAAF uptake of MeHg through biomass ingestion

\begin{tabular}{|c|c|c|c|c|}
\hline $\begin{array}{l}\text { Table B1 } \\
\text { Initial Conce } \\
\text { Spatial Area }\end{array}$ & rations and & alculated L & ds of $\mathrm{Hg}$ anc & MeHg for \\
\hline & & $g^{2+}$ & & \\
\hline Spatial Area & Conc $^{1}\left(\mathrm{ng} \mathrm{g}^{-1}\right)$ & Load $\left(\mathrm{ng} \mathrm{m}^{-2}\right)$ & Conc $^{1}\left(\mathrm{ng} \mathrm{g}^{-1}\right)$ & Load $\left(\mathrm{ng} \mathrm{m}^{-2}\right)$ \\
\hline Salicornia Marsh & 314 & $8,870,500$ & 1.11 & 31,358 \\
\hline Spartina Marsh & 407 & $11,497,750$ & 1.35 & 38,138 \\
\hline Mud Flat & 378 & $10,678,500$ & 1.78 & 50,285 \\
\hline Sub Tidal & 378 & $10,678,500$ & 1.78 & 50,285 \\
\hline
\end{tabular}




\begin{tabular}{|c|c|c|}
\hline \multicolumn{3}{|c|}{$\begin{array}{l}\text { Table B2 } \\
\text { Base Hg Methylation Rates for QnD:HAAF Spatial Areas, Under Dry } \\
\text { Season, Day-Time, Aerobic Conditions }{ }^{1}\end{array}$} \\
\hline Spatial Area & $\begin{array}{l}\text { Methylation Rate } \\
\left(\text { Fraction } \mathrm{Hg}^{2+} \mathrm{hr}^{-1} \text { ) }\right.\end{array}$ & $\begin{array}{l}\text { Fraction } \mathrm{Hg}^{2+} \text { Pool Converted } \\
\left(\text { Percent } \mathrm{hr}^{-1}\right)\end{array}$ \\
\hline Salicornia Marsh & $3.00 \times 10^{-4}$ & 0.0300 \\
\hline Spartina Marsh & $1.833 \times 10^{-4}$ & 0.01833 \\
\hline Mud Flat & $2.083 \times 10^{-4}$ & 0.02208 \\
\hline Sub Tidal $^{2}$ & $2.083 \times 10^{-4}$ & 0.02208 \\
\hline
\end{tabular}

\section{Table B3 \\ Multiplication Factors Accounting for Seasonal Effects on Methylation Rate ${ }^{1}$}

\begin{tabular}{||l|l|l||}
\hline \hline Spatial Area & Wet Season Factor & Dry Season Factor \\
\hline \hline Salicornia Marsh & 8.8 & 1.0 \\
\hline Spartina Marsh & 8.8 & 1.0 \\
\hline Mud Flat & 1.6 & 1.0 \\
\hline Sub Tidal & 1.6 & 1.0 \\
\hline \hline${ }^{1}$ Ratios estimated from field data McFarland et al. (2003a,b) \\
\hline
\end{tabular}

\begin{tabular}{|c|c|c|}
\hline \multicolumn{3}{|c|}{$\begin{array}{l}\text { Table B4 } \\
\text { Multiplication Factors for Daylight Effects on Methylation Rate }{ }^{1}\end{array}$} \\
\hline Spatial Area & Night-time Dark Factor & Day-time Light Factor \\
\hline Salicornia Marsh & 0.61 & 1.0 \\
\hline Spartina Marsh & 0.59 & 1.0 \\
\hline Mud Flat & 0.48 & 1.0 \\
\hline Sub Tidal & 0.48 & 1.0 \\
\hline
\end{tabular}

\begin{tabular}{|c|c|c|}
\hline \multicolumn{3}{|c|}{$\begin{array}{l}\text { Table B5 } \\
\text { Base Demethylation Rates, }{ }^{1} \text { Under Dry Season, Day-Time, Aerobic } \\
\text { Conditions }\end{array}$} \\
\hline Spatial Area & $\begin{array}{l}\text { Demethylation Rate } \\
\text { (Percent } \mathrm{MeHg} \mathrm{hr}^{-1} \text { ) }\end{array}$ & $\begin{array}{l}\text { Fraction } \mathrm{MeHg} \text { Pool Converted } \\
\left(\text { Percent } \mathrm{hr}^{-1}\right)\end{array}$ \\
\hline Salicornia Marsh & $2.625 \times 10^{-2}$ & 2.625 \\
\hline Spartina Marsh & $2.917 \times 10^{-2}$ & 2.917 \\
\hline Mud Flat & $3.042 \times 10^{-2}$ & 3.042 \\
\hline Sub Tidal & $3.042 \times 10^{-2}$ & 3.042 \\
\hline
\end{tabular}




\begin{tabular}{|c|c|c|}
\hline \multicolumn{3}{|c|}{$\begin{array}{l}\text { Table B6 } \\
\text { Multiplication Factors for Day-Time Light Effects on Demethylation } \\
\text { Rate }^{1}\end{array}$} \\
\hline Spatial Area & Dark Factor (6 pm - 6 am) & Light Factor (6 am - 6 pm) \\
\hline Salicornia Marsh & 0.87 & 1.0 \\
\hline Spartina Marsh & 1.27 & 1.0 \\
\hline Mud Flat & 0.97 & 1.0 \\
\hline Sub Tidal & 0.97 & 1.0 \\
\hline
\end{tabular}

\begin{tabular}{|c|c|c|c|}
\hline \multicolumn{4}{|c|}{$\begin{array}{l}\text { Table B7 } \\
\text { Initial Numbers of Individuals and Biomass of Biota in QnD:HAAF }\end{array}$} \\
\hline Biota & $\begin{array}{l}\text { Population } \\
\left(\mathrm{N} \mathrm{m}^{-2}\right)\end{array}$ & 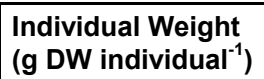 & $\begin{array}{l}\text { Biomass } \\
\left(g \mathrm{DW} \mathrm{m}^{-2}\right)\end{array}$ \\
\hline Salicornia virginica & & & $2000.0^{1}$ \\
\hline Spartina foliosa & & & $2000.0^{1}$ \\
\hline Epipelon (all areas) & & & $286.0^{2}$ \\
\hline $\begin{array}{l}\text { Ribbed Mussel (High Marsh area) } \\
\text { Ribbed Mussel (Mid Marsh area) } \\
\text { Ribbed Mussel (Mud Flat area) } \\
\text { Ribbed Mussel (Sub Tidal area) }\end{array}$ & $\begin{array}{l}12.0^{3} \\
156.0 \\
412.0 \\
412.0 \\
\end{array}$ & $\begin{array}{l}0.2^{5} \\
0.2 \\
0.2 \\
0.2\end{array}$ & \begin{tabular}{|l|}
2.4 \\
31.2 \\
82.4 \\
82.4 \\
\end{tabular} \\
\hline $\begin{array}{l}\text { Eastern Mud Snail (High Marsh area) } \\
\text { Eastern Mud Snail (Mid Marsh area) } \\
\text { Eastern Mud Snail (Mud Flat area) } \\
\text { Eastern Mud Snail (Sub Tidal area) }\end{array}$ & $\begin{array}{l}1.0^{5} \\
1.0 \\
10.0 \\
10.0 \\
\end{array}$ & $\begin{array}{l}0.1^{5} \\
0.1 \\
0.1 \\
0.1\end{array}$ & $\begin{array}{l}0.1 \\
0.1 \\
1.0 \\
1.0 \\
\end{array}$ \\
\hline Yellow Shore Crab & $1.0^{5}$ & $2.0^{5}$ & 2.0 \\
\hline Clapper Rail & $0.000125^{6}$ & $69.2^{7}$ & 0.00865 \\
\hline \multicolumn{4}{|c|}{$\begin{array}{l}{ }^{1} \text { Biomass levels estimated in Table 3-11). } \\
2130 \mathrm{~g} \mathrm{C} \mathrm{m}^{-2} \mathrm{y}^{-1} \text {, with } 1 \mathrm{~g} \mathrm{C}=2.22 \mathrm{~g} \mathrm{DW} \text { (listed in Chapter } 3 \text { of this report, Table 3-1; after Onuf } \\
1987)^{3} . \\
{ }^{4} \text { Vitaliano and Bejda (2001). } \\
{ }^{5} \text { Estimated from current field research effort. } \\
{ }^{6} \text { One rail per } 0.8 \text { ha assumed, based on density ranges Gill (1979). } \\
{ }^{7} \text { Weight per rail: } 346.1 \mathrm{~g} \text { wet or } 69.22 \mathrm{~g} \text { dry (U.S. Fish and Wildlife Service 2003). }\end{array}$} \\
\hline
\end{tabular}




\begin{tabular}{|c|c|c|c|}
\hline \multicolumn{4}{|c|}{$\begin{array}{l}\text { Table B8 } \\
\text { Initial MeHg Concentrations and MeHg Loads of Biota in } \\
\text { QnD:HAAF }\end{array}$} \\
\hline Biota & $\begin{array}{l}\text { Biomass, } \\
\mathrm{g} \mathrm{DW} \mathrm{m}^{-2}\end{array}$ & $\begin{array}{l}\text { MeHg Concentration, } \\
\text { ng g }^{-1} \text { DW }\end{array}$ & $\begin{array}{l}\text { Load, } \\
\text { ng m }^{-2}\end{array}$ \\
\hline Salicornia virginica $^{1}$ & 2000.0 & 1.64 & 3280.0 \\
\hline Spartina foliosa $^{1}$ & 2000.0 & 2.52 & 5040.0 \\
\hline Epipelon (all areas) $^{1}$ & 286.0 & 1.5 & 429.0 \\
\hline $\begin{array}{l}\text { Ribbed Mussel (High Marsh area) } \\
\text { Ribbed Mussel (Mid Marsh area) } \\
\text { Ribbed Mussel (Mud Flat area) } \\
\text { Ribbed Mussel (Sub Tidal area) }\end{array}$ & $\begin{array}{l}2.4 \\
31.2 \\
82.4 \\
82.4\end{array}$ & \begin{tabular}{|l|}
1.86 \\
1.86 \\
1.86 \\
1.86
\end{tabular} & $\begin{array}{l}4.46 \\
58.0 \\
153.3 \\
153.3\end{array}$ \\
\hline $\begin{array}{l}\text { Eastern Mud Snail (High Marsh area) } \\
\text { Eastern Mud Snail (Mid Marsh area) } \\
\text { Eastern Mud Snail (Mud Flat area) } \\
\text { Eastern Mud Snail (Sub Tidal area) } \\
\end{array}$ & $\begin{array}{l}0.1 \\
0.1 \\
1.0 \\
1.0\end{array}$ & $\begin{array}{l}7.9 \\
7.9 \\
7.9 \\
7.9 \\
\end{array}$ & \begin{tabular}{|l|}
0.79 \\
0.79 \\
7.9 \\
7.9 \\
\end{tabular} \\
\hline Yellow Shore Crab & 2.0 & 1.72 & 3.44 \\
\hline Clapper Rail & 0.00865 & $0.1^{2}$ & 0.00865 \\
\hline
\end{tabular}

\section{Table B9}

\section{Predators and Prey Demands}

\begin{tabular}{|c|c|}
\hline Predator & Prey Demand, g prey-DW g ${ }^{-1}$ predator-DW $\mathrm{hr}^{-1}$ \\
\hline$\overline{\text { Eastern Mud Snail }^{1}}$ & Epipelon Demand $=0.0042$ \\
\hline Yellow Shore $\mathrm{Crab}^{2}$ & $\begin{array}{l}\text { Epipelon }=0.0003 \\
\text { Eastern Mud Snail }=0.0003 \\
\text { Ribbed Mussel }=0.0003\end{array}$ \\
\hline Clapper Rail ${ }^{3}$ & $\begin{array}{l}\text { Ribbed Mussel }=0104 \\
\text { Eastern Mud Snail }=0.0052 \\
\text { Yellow Shore Crab }=0.0052\end{array}$ \\
\hline \multicolumn{2}{|c|}{$\begin{array}{l}{ }_{1}^{1} \text { Assumed demand is } 10 \text { percent predator-biomass per day. } \\
{ }^{2} \text { Assumed demand is } 20 \text { percent predator-biomass per day. } \\
{ }^{3} \text { Assumed demand is } 50 \text { percent predator-biomass per day. Food source composed by: ribbed } \\
\text { mussels }(0.5) \text {, mud snails }(0.25) \text { and shore crabs }(0.25) \text {. After U.S. Fish and Wildlife Service }(2003)\end{array}$} \\
\hline
\end{tabular}

\section{Table B10}

Predators and Mass Loss Rates to Keep Biomass Pools Constant Over Short Periods

\begin{tabular}{|c|c|}
\hline Predator & Mass loss rate, $\mathrm{g}$ lost-DW $\mathrm{g}^{-1}$ predator-DW $\mathrm{hr}^{-1}$ \\
\hline Eastern Mud Snail $^{1}$ & 0.006 \\
\hline Yellow Shore $\mathrm{Crab}^{2}$ & 0.006 \\
\hline Clapper Rail $^{3}$ & 0.021 \\
\hline \multicolumn{2}{|c|}{$\begin{array}{l}{ }^{1} \text { Assumed mass loss rate is } 10 \text { percent predator-biomass per day. } \\
{ }^{2} \text { Assumed mass loss rate is } 20 \text { percent predator-biomass per day. } \\
{ }^{3} \text { Assumed mass loss rate is } 50 \text { percent predator-biomass per day. }\end{array}$} \\
\hline
\end{tabular}




\begin{tabular}{|c|c|c|c|c|}
\hline \multicolumn{5}{|c|}{$\begin{array}{l}\text { Table B11 } \\
\text { Comparison of Daily Methylation and Demethylation Rates for } \\
\text { Salicornia-Vegetated High Marsh }\end{array}$} \\
\hline \multirow[b]{2}{*}{ Process } & \multicolumn{2}{|c|}{ Marvin-DiPasquale et al.(2003) ${ }^{1}$} & \multicolumn{2}{|c|}{ QnD:HAAF } \\
\hline & $\begin{array}{l}\text { Potential Rate, } \\
\text { ng g }^{-1} \text { DW day } \\
\end{array}$ & $\begin{array}{l}\text { In-situ Rate, } \\
\text { ng g }^{-1} \text { DW day }\end{array}$ & $\begin{array}{l}\text { Wet season, } \\
\text { ng g }^{-1} \text { DW day }\end{array}$ & $\begin{array}{l}\text { Dry season, } \\
\text { ng g }^{-1} \text { DW day } \\
\end{array}$ \\
\hline Methylation & $6.2(2.84)$ & $3.6(1.8)$ & 8.46 & 1.00 \\
\hline Demethylation & $6.3(2.0)$ & $1.1(0.8)$ & 7.47 & 0.96 \\
\hline \multicolumn{5}{|c|}{$\begin{array}{l}\text { Note: measured by Marvin-DiPasquale et al. (2003; mean values and standard deviations) versus } \\
\text { simulated by QnD:HAAF. } \\
{ }^{1} \text { Rates measured in March were converted from a wet-weight basis to a dry-weight basis, } \\
\text { assuming } 50 \text { percent water, } 50 \text { percent solids. }\end{array}$} \\
\hline
\end{tabular}




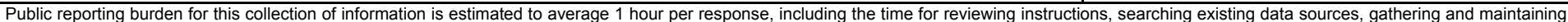

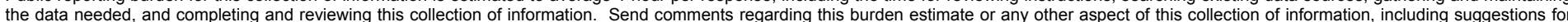

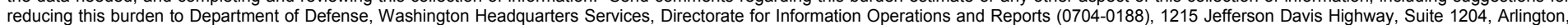

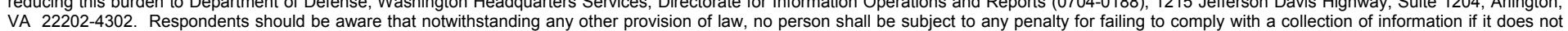
VA 22202-4302. Respondents should be aware that notwithstanding any other provision of law, no person shall be
display a currently valid OMB control number. PLEASE DO NOT RETURN YOUR FORM TO THE ABOVE ADDRESS.

\begin{tabular}{l|r}
$\begin{array}{l}\text { 1. REPORT DATE (DD-MM-YYYY) } \\
\text { September } 2005\end{array}$ & $\begin{array}{r}\text { 2. REPORT TYPE } \\
\text { Interim report }\end{array}$ \\
\hline
\end{tabular}

4. TITLE AND SUBTITLE

Pre-Construction Biogeochemical Analysis of Mercury in Wetlands Bordering the

Hamilton Army Airfield Wetlands Restoration Site

3. DATES COVERED (From - To)

5a. CONTRACT NUMBER

5b. GRANT NUMBER

5c. PROGRAM ELEMENT NUMBER

5d. PROJECT NUMBER

5e. TASK NUMBER

E. P. H. Best, H. L. Fredrickson, V. A. McFarland, H. Hintelmann, R. P. Jones,

C. H. Lutz, G. A. Kiker, A. J. Bednar, R. N. Millward, R. A. Price, G. R. Lotufo, and

G. A. Ray

5f. WORK UNIT NUMBER

8. PERFORMING ORGANIZATION REPORT NUMBER

ERDC/EL TR-05-15

Environmental Laboratory, U.S. Army Engineer Research and Development Center, 3909

Halls Ferry Road, Vicksburg, MS 39180-6199

Trent University, 1600 West Bank Drive, Peterborough, ON K9J 7B8, Canada

Analytical Services, Inc., 3532 Manor Drive, Suite \#3, Vicksburg, MS 39180

9. SPONSORING / MONITORING AGENCY NAME(S) AND ADDRESS(ES)

10. SPONSOR/MONITOR'S ACRONYM(S)

U.S. Army Corps of Engineers, San Francisco District

333 Market Street, San Francisco, CA 94105-2197

11. SPONSOR/MONITOR'S REPORT NUMBER(S)

\section{DISTRIBUTION / AVAILABILITY STATEMENT}

Approved for public release; distribution is unlimited.

\section{SUPPLEMENTARY NOTES}

\section{ABSTRACT}

Over 90 percent of the coastal wetlands in San Francisco Bay have been lost since the industrial revolution. The U.S. Army Corps of Engineers (USACE) is working with the California State Coastal Conservancy and the San Francisco Bay Conservation and Development Commission (BCDC) to reconstruct wetlands at Hamilton Army Airfield (HAAF) and restore 203 ha of tidal habitat to endangered species such as the clapper rail and the saltmarsh harvest mouse. HAAF has subsided below mean sea level and will require 10 million cu yd of fill material to elevate the site to the point where typical marsh vegetation can colonize and the natural sediment trapping, marsh-building physical dynamics can proceed. Wetlands are believed to be sources of methylmercury (MeHg) production and export, and HAAF represents only 203 ha of the additional 23,300 ha of wetlands to be established around the bay by 2055 . Means to mitigate MeHg magnification in bay aquatic food webs are needed but currently unknown. This interim report describes site-specific information collected in 2003 on the geochemical/geophysical, microbial, predominant plant- and animal-related interactions that affect stabilization and mobilization of $\mathrm{Hg}$ and $\mathrm{MeHg}$ in the sediments/soils of the area.

(Continued)

\begin{tabular}{|ll}
\hline 15. SUBJECT TERMS & Mercury \\
Bioavailability & Methylation \\
Demethylation & Methylmercury
\end{tabular}

16. SECURITY CLASSIFICATION OF:

\begin{tabular}{|l|l|}
\hline a. REPORT & b. ABSTRACT \\
UNCLASSIFIED & UNCLASSIFIED \\
\hline
\end{tabular}

c. THIS PAGE

UNCLASSIFIED
Remediation

Screening-level modeling

Wetlands restoration

\begin{tabular}{|l|c|l|}
\hline $\begin{array}{l}\text { 17. LIMITATION } \\
\text { OF ABSTRACT }\end{array}$ & $\begin{array}{l}\text { 18. NUMBER } \\
\text { OF PAGES }\end{array}$ & $\begin{array}{l}\text { 19a. NAME OF RESPONSIBLE } \\
\text { PERSON }\end{array}$ \\
\cline { 3 - 3 } & 160 & $\begin{array}{l}\text { 19b. TELEPHONE NUMBER (include } \\
\text { area code) }\end{array}$ \\
& & \\
\hline
\end{tabular}




\section{ABSTRACT (continued)}

Total mercury (THg) and MeHg levels were measured in June 2003 in the sediment in relation to depth at intertidal sites at HAAF and the China Camp State Park (as a reference), as well as at inland sites at HAAF and Bel Marin Creek. Other parameters important for the cycling of $\mathrm{Hg}$ and $\mathrm{MeHg}$ in sediments were determined also to establish site-specific relationships between these parameters and $\mathrm{THg}$ and $\mathrm{MeHg}$. The highest $\mathrm{MeHg}$ concentrations (range 0.8-4.4 mg g${ }^{-1} \mathrm{DW}$ ) were found in the upper 2.5-5.1 $\mathrm{cm}$ of the cores and levels decreased with depth. THg levels (range 160-550 $\mathrm{ng} \mathrm{g}^{-1}$ ) increased with depth, correlating inversely with $\mathrm{MeHg}$. MeHg correlated directly with redox potential $\left(\mathrm{E}_{\mathrm{h}}\right)$, total organic carbon, and phosphorus. Net MeHg production is the result of methylation and demethylation rates in the sediment. Methylation and demethylation rates were determined by on-site incubations of mud- and vegetated-mud cores with stable $\mathrm{Hg}$ isotopes at the HAAF and China Camp sites. Methylation rates were $1.44 \mathrm{ng} \mathrm{MeHg} \mathrm{g}^{-1}$ per day in nonvegetated sediments of HAAF. Rates were usually lower in vegetated than in nonvegetated sediments. Rates were usually higher in the light than in darkness. Methylation rates varied with location within the bay on bare and epipelon-vegetated sites and were lower at HAAF than at China Camp. Epipelon is the complex of microalgae, bacteria, and detritus on the sediment surface. Demethylation rates were $1.281 \mathrm{ng} \mathrm{MeHg} \mathrm{g}^{-1}$ per day in nonvegetated sediments at $\mathrm{HAAF}$ and $0.78 \mathrm{ng} \mathrm{MeHg} \mathrm{g}^{-1}$ per day at China Camp.

Mean THg concentrations in the macrophytic vegetation, predominated by Spartina foliosa and Salicornia virginica, ranged from 13 to $158 \mathrm{ng} \mathrm{g}^{-1}$ in shoots and from 217 to $297 \mathrm{ng} \mathrm{g}^{-1}$ in roots. Mean MeHg concentration ranged from 0.55 to $4.75 \mathrm{ng} \mathrm{g}^{-1}$ in shoots and from 2.83 to 5.26 in roots. Plant levels usually exceeded those in the sediments in which they rooted. The THg and MeHg levels in plant detritus were far higher than in live shoots, i.e., by a factor of 5 to 8. Significant levels of THg and $\mathrm{MeHg}$ were detected in tissues of macrofauna collected at intertidal sites of HAAF and China Camp. MeHg comprised on average 40 percent of THg (range 20-70 percent). Biota to sediment accumulation factors (BAFs) for MeHg ranged from about 3 to 50. Snails were the highest Hg bioaccumulators. Because the diet of these animals is composed largely of plant material, it is likely that MeHg in plants represents an important $\mathrm{MeHg}$ source for trophic transfer in the marsh. A preliminary annual $\mathrm{MeHg}$ mass balance for a 203-ha HAAF system indicated a net MeHg production of $12.8 \mathrm{~kg}$ and $\mathrm{MeHg}$ export in the order of $0.1 \mathrm{~kg}$ with tidal waters to the bay. These values serve as the basis for research hypotheses and future work.

Measures to decrease bioavailability were explored as a management tool. The bioavailability characteristics of $\mathrm{Hg}$ species in HAAF sediments were evaluated experimentally. The MeHg body burdens of the experimentally 2-56 days exposed Macoma nasuta clams were only approximately half of those recorded in clams inhabiting bay edge sediments while elimination was slow, suggesting that exposure periods longer than 56 days are needed for $\mathrm{Hg}$ to approach apparent steady state in clam tissues. Bioavailability decreased more by sediment amendment with granular activated carbon (GAC) than with Kraft-lignin.

A screening-level model pertaining to HAAF (QnD:HAAF) was created to serve as a tool to incorporate ecosystem characteristics and management measures into a user-friendly framework. This model links the spatial components within GIS files to the prevalent abiotic, climatic, and biotic interactions in the ecosystem. It has a simple design and can be upgraded easily. The current QnD:HAAF version 1.0 integrates the field and laboratory data pertaining to HAAF and other related systems. The model was run to simulate two 14-day scenarios, representing the wet and dry season, respectively. Simulated sediment MeHg concentrations exceeded the measured levels while simulated methylation and demethylation rates were on the same order of magnitude as measured values. Elevation proved to be an important factor influencing net MeHg production. The differences between the simulated and measured THg and MeHg levels in sediment and biota may provide leads to identify areas in which more information is needed.

Future research efforts will address processes determining net $\mathrm{MeHg}$ production, atmospheric flux of $\mathrm{Hg}$, exchange of $\mathrm{Hg}$ and $\mathrm{MeHg}$ between sediment and tidal waters, biomagnification of $\mathrm{Hg}$ up relevant aquatic food webs, data integration, and management issues. 